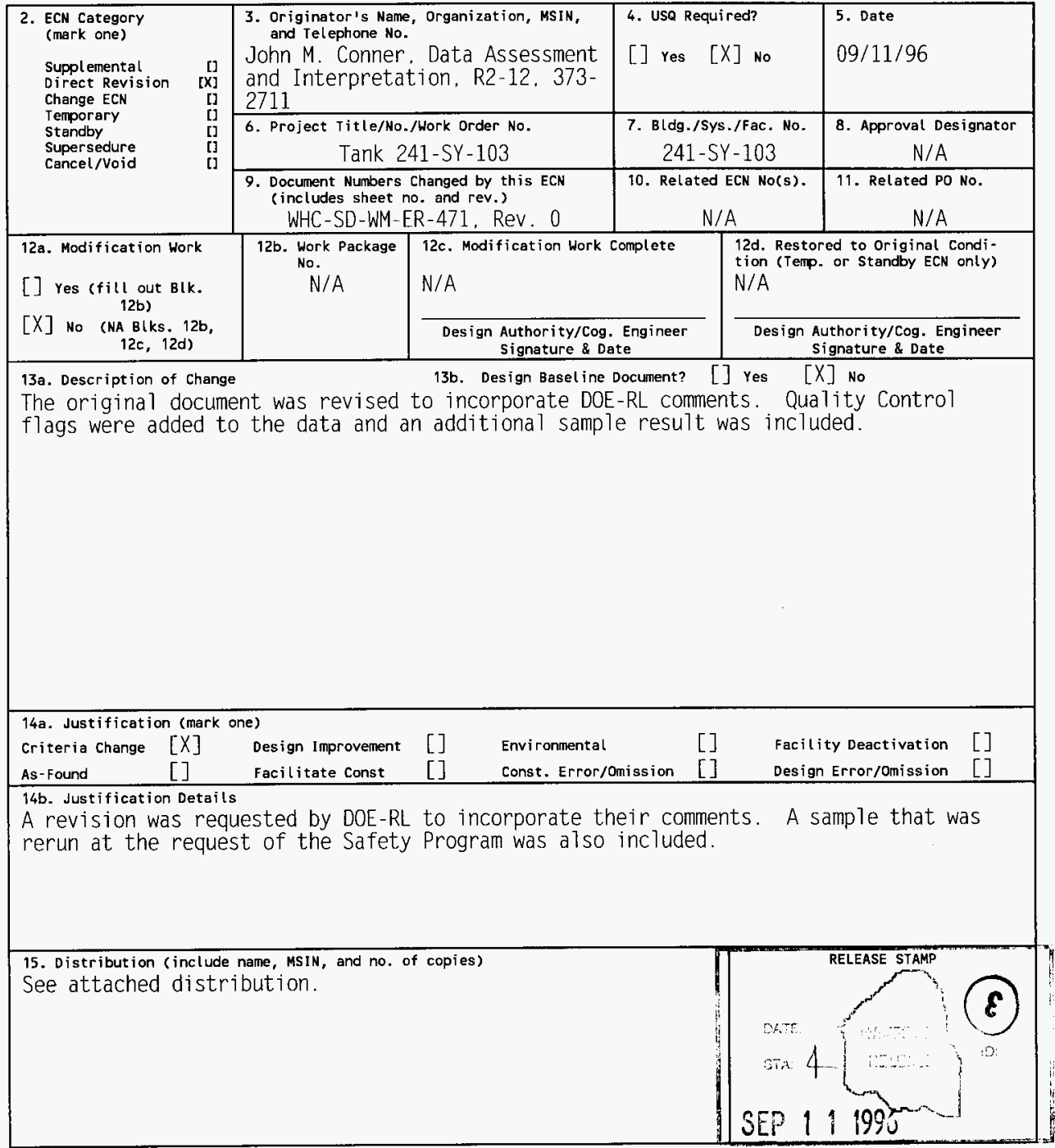




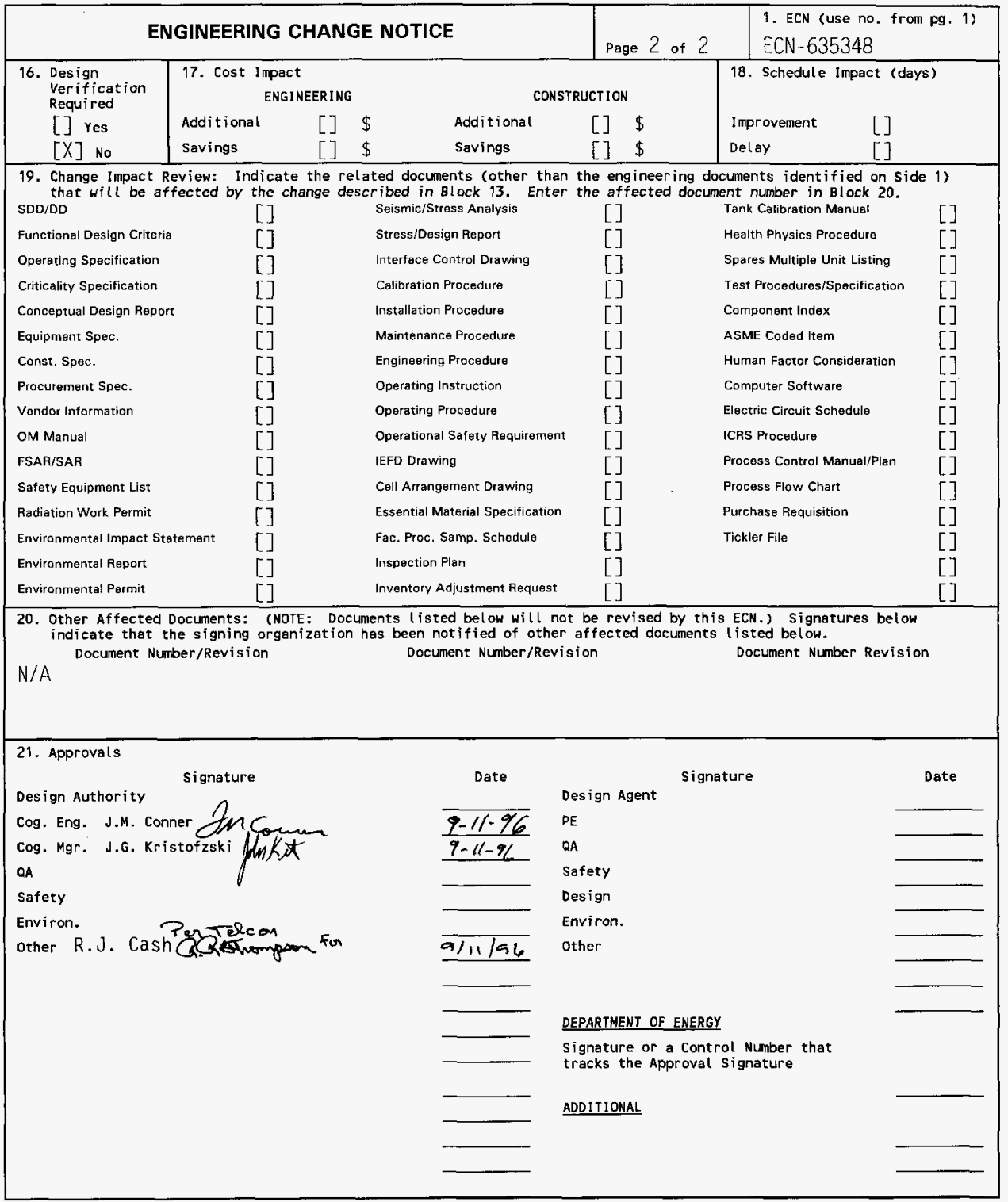




\section{Tank Characterization Report for Double-Shell Tank 241-SY-103}

John M. Conner

Westinghouse Hanford Company, Richland. WA 99352

U.S. Department of Energy Contract DE-AC06-87RL10930

$\begin{array}{lll}\text { EDT/ECN: } & \text { ECN }-635348 & \text { UC: } 2070 \\ \text { Org Code: } & 79400 & \text { Charge Code: N4G40 } \\ \text { B\&R Code: } & \text { EW } 3120074 & \text { Total Pages:/59 }\end{array}$

Key Words: Waste Characterization, Double-She11 Tank. Tank 241-SY-103. Tank SY-103, SY-103, SY Farm. Tank Characterization Report, Waste Inventory, TPA Milestone M-44

Abstract: This document summarizes the information on the historical uses, present status, and the sampling and analysis results of waste stored in tank 241-SY-103. This report supports the requirements of Tri-Party Agreement Mi lestone M-44-09.

TRADEMARK DISCLAIMER. Reference herein to any specific commercial product, process, or service by trade name, trademark, manufacturer, or otherwise, does not necessarily constitute or imply its endorsement, recomendation, or favoring by the United States Government or any agency thereof or its contractors or subcontractors.

Printed in the United States of America. To obtain copies of this document, contact: WHC/BCS Document Control Services, P.O. Box 1970, Mailstop H6-08, Richland WA 99352, Phone (509) 372-2420; Fax (509) 376-4989.
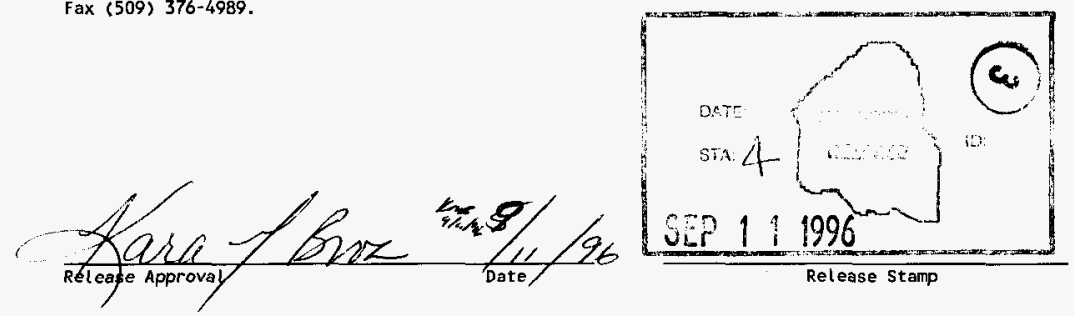

\section{Approved for Public Release}




\section{RECORD OF REVISION}

(2) Title

Tank Characterization Report for Double-Shell Tank 241-SY-103 CHANGE CONTROL RECORD

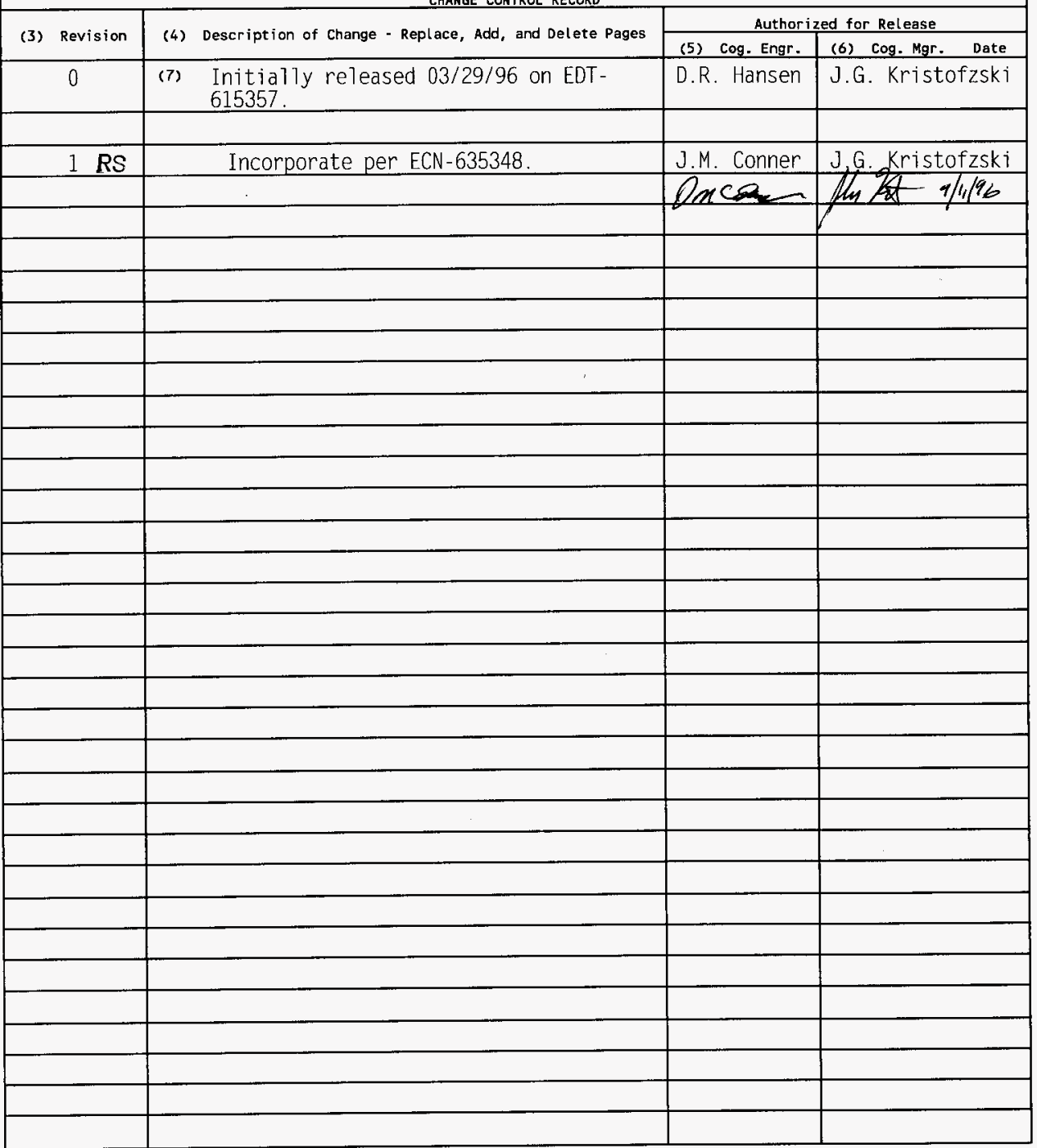




\section{Tank Characterization Report for Double-Shell Tank 241-SY-103}

Prepared for the U.S. Department of Energy Assistant Secretary for Environmental Management

\footnotetext{
We Westinghouse

Hanford Company Richland, Washington
}

Management and Operations Contractor for the

U.S. Department of Energy under Contract DE-AC06-87RL 10930

Approved for Public Release, distribution unlimited. 


\title{
Tank Characterization Report for Double-Shell Tank 241-SY-103
}

\author{
D. R. Hansen \\ S. G. Metcalf \\ J. G. Douglas \\ W. I. Winters \\ Westinghouse Hanford Company \\ K. W. Johnson \\ J. D. Franklin \\ Los Alamos Technical Associates \\ Date Published \\ September 1996
}

Prepared for the U.S. Department of Energy

Assistant Secretary for Environmental Management

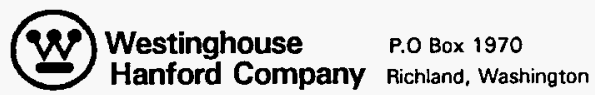

Management and Operations Contractor for the

U.S. Department of Energy under Contract DE-AC06-87RL10930

Approved for Public Release, distribution unlimited. 


\section{EXECUTIVE SUMMARY}

This tank characterization report summarizes information on the historical uses, current status, and the sampling and analysis results of waste stored in double-shell underground storage tank 241-SY-103 at the Hanford Site. This report also supports the requirements of the Hanford Federal Facility Agreement and Consent Order (Ecology et al. 1996), Milestone M-44-09.

Tank 241-SY-103 is located in the SY Tank Farm in the 200 West Area of the Hanford Site. The tank went into service in 1977 and received concentrated wastes from B Plant cesium and strontium recovery campaigns. In 1980, most of this waste was transferred out, and double-shell slurry was transferred into the tank. In 1985, uranium sludge from ionexchange processing was added to the tank. No transfers from tank 241-SY-103 have occurred since January 1981. Small additions of waste water from many sources were made to the tank between 1981 and 1989 . No waste has been added since 1990 .

Table ES-1 and Figure ES-1 summarize the description and status of tank 241-SY-103. The tank is currently in service, but it is prohibited from receiving any waste because it is on the Flammable Gas Watch List. The tank, which has an operational capacity of $4,390 \mathrm{~kL}$ $(1,160 \mathrm{kgal})$, is estimated to contain $2,824 \mathrm{~kL}$ (746 kgal) of waste in the form of supernate and solids (Hanlon 1996). The last sampling of the tank was a core sample taken in 1994. Based on that core sample, the tank is estimated to contain 1,440 kL (380 kgal) in an upper layer of supernate and $1,370 \mathrm{~kL}(362 \mathrm{kgal})$ in a lower layer of solids. 
Table ES-1. Description and Status of Tank 241-SY-103.

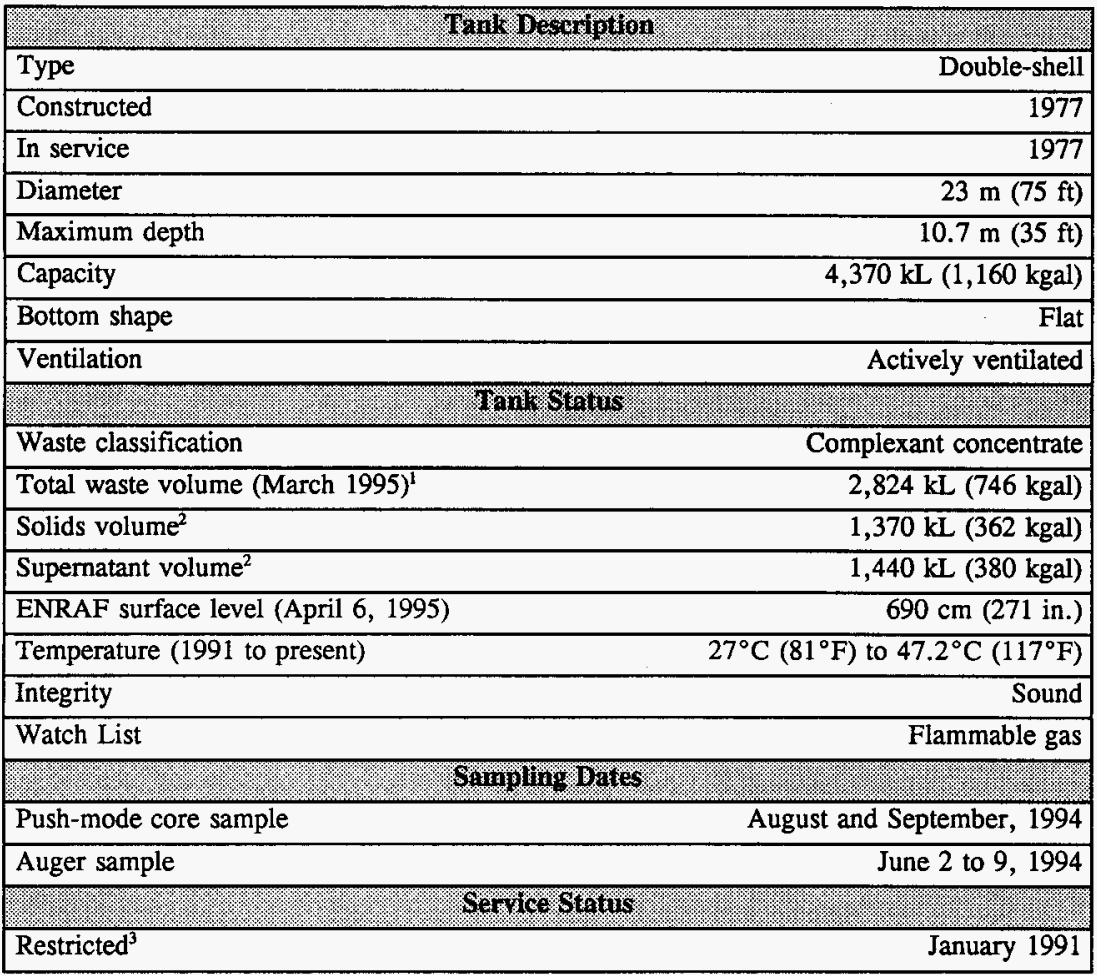

Notes:

${ }^{1}$ Hanlon (1996)

${ }^{2}$ Estimated from 1994 core sample.

${ }^{3}$ There has been no transfers of waste since 1990 . 
Figure ES-1. Basic Design of a Double-Shell Tank.

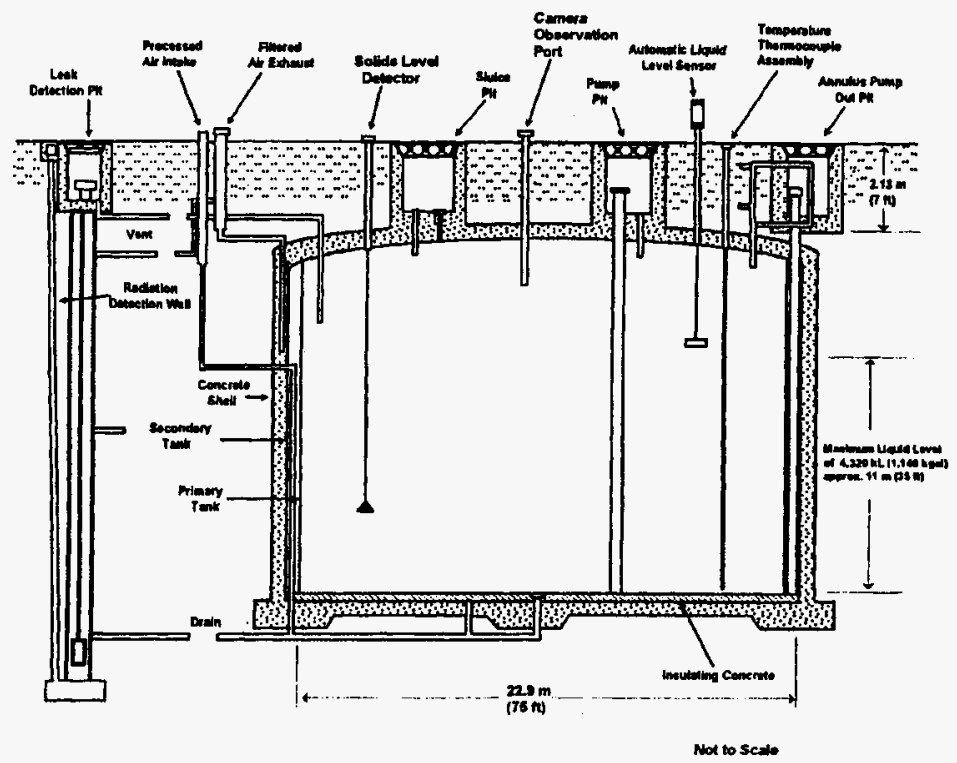


This report summarizes three sampling and analysis events.

- The solids and supernate compositions are based on the core sample taken in 1994.

- The crust was evaluated for safety concerns using auger solids in 1994.

- The physical properties of the solids presented were taken from 1986 and 1994 core segment samples.

An unreviewed safety question raised concern that the crust of the tank waste could become sufficiently hot during core sampling activities to initiate an exothermic reaction or ignite hydrogen gas, if present (Johnson 1994). General safety screening analyses were performed on the crust prior to core sampling in response to the unreviewed safety question. The differential scanning calorimetry (DSC) results did not exhibit exotherms, thus indicating that it was safe to obtain a push-mode core sample (Schreiber 1995).

Two data quality objectives (DQOs) were applicable to the 1994 core sampling event: the Flammable Gas Tank Safety Programs: Data Requirements for Core Sample Analysis Developed Through the Data Quality Objective Process (McDuffie and Johnson 1994) and the Tank Safety Screening Data Quality Objective (Babad and Redus 1994). The flammable gas safety $\mathrm{DQO}$ requires one core, and the safety screening DQO requires two cores taken from two widely separated risers. Because of safety concerns, only one core was acquired; therefore, although the objectives were met for the flammable gas safety DQO, they were not met for the safety screening DQO. Safety screening analyses were performed on the one core obtained. 
Safety screening analyses were performed to evaluate the potential for exothermic reactions in the waste, criticality, and tank vapor flammability. The DSC results for one drainable liquid (segment 9, $559 \mathrm{~J} / \mathrm{g}$ ) and one lower semi-segment (segment 13, $630 \mathrm{~J} / \mathrm{g}$ ) exceeded the safety screening exothermic enthalpy criteria of $480 \mathrm{~J} / \mathrm{g}$ based on the dry weight of the sample. ${ }^{1}$ Most segments exhibited an exotherm, thus indicating that fuel is present throughout the tank. However, the weight percent water content of the waste is significantly above the 17 weight percent criteria and would prevent propagation of any potential reaction.

The exothermic behavior is most likely the result of the reaction of organic complexants with nitrates/nitrites at elevated temperatures. Total organic carbon (TOC) concentrations are relatively high in each segment. The samples with the larger exotherms had dry weight TOC concentrations near 2 weight percent, which is below the safety screening criteria of 3 weight percent. Energy estimates calculated from the TOC concentration, assuming that the TOC is acetate, were all greater than the observed exotherms from DSC analysis except for two samples. Only small amounts of cyanide were found in the waste and do not contribute significantly to the observed energetics.

The heat generated by radioactivity in the tank is estimated to be $5,880 \mathrm{~W}(20,100 \mathrm{Btu} / \mathrm{hr})$, which is well below the criteria $(11,720 \mathrm{~W}[40,000 \mathrm{Btu} / \mathrm{hr}])$ distinguishing a high-heat tank

'The safety screening criteria at the time of the analysis was $523 \mathrm{~J} / \mathrm{g}$, but it has been changed to $480 \mathrm{~J} / \mathrm{g}$ in later DQOs. 
from a low-heat tank. In 1994, tank 241-SY-103 had maximum temperatures ranging from 36 to $39^{\circ} \mathrm{C}\left(96\right.$ to $\left.103{ }^{\circ} \mathrm{F}\right)$. The trend of the temperature data indicates the waste is cooling.

Total alpha results indicate that the tank is well below the criticality safety criterion of $41 \mu \mathrm{Ci} / \mathrm{g}$, but actinide levels in the solids exceed the transuranic classification of $100 \mathrm{nCi} / \mathrm{g}$. Isotopic analyses indicates that most of the alpha activity is from ${ }^{241} \mathrm{Am}$ and not ${ }^{239 / 240} \mathrm{Pu}$. The actinide levels in the supernate are well below the transuranic classification.

A standard hydrogen monitoring system was installed in June 1994. Headspace sampling indicates the presence and periodic buildup of hydrogen gas. The largest hydrogen concentration measured was 0.294 volume percent on May 2, 1995. This result is equivalent to 7.4 percent of the lower flammability limit (LFL) and does not exceed the tank safety DQO criterion of 25 percent of the LFL (Babad and Redus 1994).

Ammonia monitors on the SY tank farm indicate the highest ammonia concentration during a gas release event is about 486 ppmv or 0.3 percent of the LFL for ammonia. Additional waste characterization data were obtained to clarify mechanisms for gas generation, retention, and release. These data will be used in models of waste behavior to support evaluation of gas accumulation and development of any needed mitigation methods. Discussion of these mechanisms, models, and mitigation efforts is beyond the scope of this 
report. The gas monitoring indicates the tank vapor is well below the flammability limits even during gas release events. However, the potential for these limits being exceeded in gases entrapped in the waste is still being evaluated.

Table ES-2 summarizes the tank inventories for the supernate and solids layers of the waste in tank 241-SY-103. The summary is based on the results from the 1994 core sample. The supernate layer contains large amounts of sodium, aluminum, chloride, hydroxide, nitrite, nitrate, and complexants. The solids layer contains large amounts of chloride, nitrite, nitrate, phosphate, sulfate, hydroxide, aluminum, chromium, sodium, and complexants (estimated from TOC). 
Table ES-2, Tank 241-SY-103 Inventory. (2 Sheets)

\begin{tabular}{|c|c|c|c|}
\hline (x) & 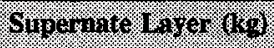 & 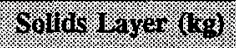 & $180+16 \%$ \\
\hline Formate ${ }^{-}$ & $6.12 E+3$ & $1.07 \mathrm{E}+4$ & $1.68 \mathrm{E}+4$ \\
\hline Oxalate $^{2-}$ & $\mathrm{n} / \mathrm{a}$ & $4.47 \mathrm{E}+4$ & $4.47 \mathrm{E}+4$ \\
\hline $\mathrm{Cl}^{-}$ & $1.64 \mathrm{E}+4$ & $1.51 E+4$ & $3.15 \mathrm{E}+4$ \\
\hline $\mathrm{F}^{-}$ & $\mathrm{n} / \mathrm{a}$ & $3.35 E+3$ & $3.35 E+3$ \\
\hline $\mathrm{NO}_{2}^{-}$ & $2.01 \mathrm{E}+5$ & $1.76 \mathrm{E}+5$ & $3.77 \mathrm{E}+5$ \\
\hline $\mathrm{NO}_{3}^{-}$ & $2.93 E+5$ & $2.11 E+5$ & $5.04 \mathrm{E}+5$ \\
\hline $\mathrm{PO}_{4}^{3-}$ & $6.99 E+3$ & $3.35 \mathrm{E}+4$ & $4.05 E+4$ \\
\hline $\mathrm{SO}_{4}^{2-}$ & $1.96 \mathrm{E}+2$ & $1.68 \mathrm{E}+4$ & $1.70 \mathrm{E}+4$ \\
\hline $\mathrm{OH}^{-}$ & $4.01 E+4$ & $3.96 E+4$ & $7.97 \mathrm{E}+4$ \\
\hline $\mathrm{Al}$ & $5.99 \mathrm{E}+4$ & $8.51 E+4$ & $1.47 \mathrm{E}+5$ \\
\hline B & $1.2 \mathrm{E}+2$ & $\mathrm{n} / \mathrm{a}$ & $1.2 \mathrm{E}+2$ \\
\hline $\mathrm{Ca}$ & $1.87 \mathrm{E}+2$ & $7.52 E+2$ & $9.39 E+2$ \\
\hline $\mathrm{Cr}$ & $4.9 \mathrm{E}+1$ & $2.19 E+4$ & $2.19 E+4$ \\
\hline $\mathrm{K}$ & $5.67 E+3$ & $7.18 \mathrm{E}+3$ & $1.28 \mathrm{E}+4$ \\
\hline $\mathrm{Na}$ & $3.17 E+5$ & $4.02 E+5$ & $7.19 E+5$ \\
\hline $\mathrm{Ni}$ & $7.1 \mathrm{E}+1$ & $2.19 E+2$ & $2.9 E+2$ \\
\hline $\mathrm{Si}$ & $1.07 \mathrm{E}+2$ & $n / a$ & $1.07 \mathrm{E}+2$ \\
\hline $\mathrm{Zn}$ & 5 & $4.9 E+1$ & $5.4 \mathrm{E}+1$ \\
\hline $\mathrm{Zr}$ & $\mathrm{n} / \mathrm{a}$ & $1.23 E+2$ & $1.23 E+2$ \\
\hline $\mathrm{Fe}$ & 7 & $5.80 E+3$ & $5.81 E+3$ \\
\hline $\mathrm{U}$ & 4 & $1.67 E+3$ & $1.67 \mathrm{E}+3$ \\
\hline TOC & $2.89 E+4^{1}$ & $9.02 \mathrm{E}+3^{1}$ & $3.79 \mathrm{E}+4^{1}$ \\
\hline TIC & $n / a$ & $9.46 \mathrm{E}+4^{2}$ & $9.46+04^{2}$ \\
\hline
\end{tabular}


WHC-SD-WM-ER-471 Rev. 1

Table ES-2. Tank 241-SY-103 Inventory. (2 Sheets)

\begin{tabular}{|c|c|c|c|}
\hline (ivalle & 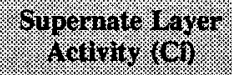 & $\begin{array}{l}\text { Solids I inger } \\
\text { activit. }(\mathrm{Cr})\end{array}$ & folat $4.016 n t y$ \\
\hline${ }^{241} \mathrm{Am}$ & 2.36 & $1.44 \mathrm{E}+3$ & $1.44 \mathrm{E}+3$ \\
\hline${ }^{137} \mathrm{Cs}$ & $5.96 \mathrm{E}+5$ & $5.38 \mathrm{E}+5$ & $1.13 E+6$ \\
\hline${ }^{60} \mathrm{Co}$ & $\mathrm{n} / \mathrm{a}$ & $1.05 \mathrm{E}+2$ & $1.05 \mathrm{E}+2$ \\
\hline${ }^{154} \mathrm{Eu}$ & $n / a$ & $1.62 \mathrm{E}+3$ & $1.62 E+3$ \\
\hline${ }^{155} \mathrm{Eu}$ & $n / a$ & $1.41 \mathrm{E}+3$ & $1.41 \mathrm{E}+3$ \\
\hline${ }^{129} \mathrm{I}$ & $2.58 \mathrm{E}-1$ & $\mathrm{n} / \mathrm{a}$ & $2.58 \mathrm{E}-1$ \\
\hline${ }^{238} \mathrm{Pu}$ & $5.75 \mathrm{E}-1$ & $3.48 \mathrm{E}+1$ & $3.54 \mathrm{E}+1$ \\
\hline${ }^{239 / 240} \mathrm{Pu}$ & $\mathrm{n} / \mathrm{a}$ & $1.34 \mathrm{E}+2$ & $1.34 \mathrm{E}+2$ \\
\hline${ }^{90} \mathrm{Sr}$ & $4.21 \mathrm{E}+3$ & $7.48 \mathrm{E}+4$ & $7.90 \mathrm{E}+4$ \\
\hline${ }^{99} \mathrm{Tc}$ & $2.41 \mathrm{E}+2$ & $5.25 E+2$ & $7.66 \mathrm{E}+2$ \\
\hline Tritium & 3.16 & $\mathrm{n} / \mathrm{a}$ & 3.16 \\
\hline Total alpha & $n / a$ & $1.17 \mathrm{E}+3$ & $1.17 \mathrm{E}+3$ \\
\hline Total beta & $5.97 \mathrm{E}+5$ & $9.29 \mathrm{E}+5$ & $1.53 \mathrm{E}+6$ \\
\hline
\end{tabular}

Notes:

$\mathrm{n} / \mathbf{a}=$ not available, all results were below detection limits

'As kg of acetate, corrected for formate and oxalate concentration.

${ }^{2}$ As kg of carbonate. 
WHC-SD-WM-ER-471 Rev. 1

This page intentionally left blank. 


\section{CONTENTS}

1.0 INTRODUCTION $\ldots \ldots \ldots \ldots \ldots \ldots \ldots \ldots \ldots \ldots \ldots \ldots \ldots \ldots \ldots \ldots \ldots .11$

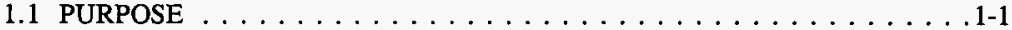

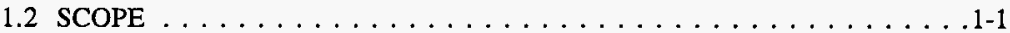

2.0 HISTORICAL TANK INFORMATION $\ldots \ldots \ldots \ldots \ldots \ldots \ldots \ldots \ldots .2$.

2.1 TANK STATUS $\ldots \ldots \ldots \ldots \ldots \ldots \ldots \ldots \ldots \ldots \ldots \ldots \ldots \ldots \ldots \ldots \ldots .2-1$

2.2 TANK DESIGN $\ldots \ldots \ldots \ldots \ldots \ldots \ldots \ldots \ldots \ldots \ldots \ldots \ldots \ldots \ldots \ldots .22$

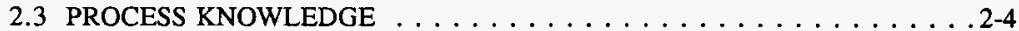

2.3.1 Waste Transfer History . . . . . . . . . . . . . . 2-7

2.3.2 Historical Estimate of Contents . . . . . . . . . 2-8

2.4 SURVEILLANCE DATA . . . . . . . . . . . . . . 2-10

2.4 .1 Surface Level Readings $\ldots \ldots \ldots \ldots \ldots \ldots \ldots \ldots \ldots . \ldots \ldots$

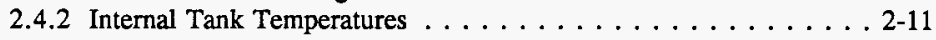

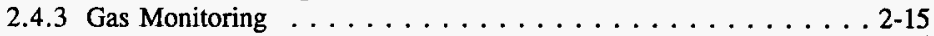

2.4 .4 In-Tank Photographs . . . . . . . . . . . 2-15

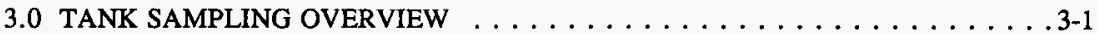

3.1 DESCRIPTION OF THE 1994 CORE SAMPLING EVENT $\ldots \ldots \ldots \ldots$. . . .

3.1.1 1994 Core Sample Handling . . . . . . . . . . . . . . 3-3

3.1 .21994 Core Sample Analysis . . . . . . . . . . . . . . . . 3-6

3.2 DESCRIPTION OF JUNE 1994 AUGER SAMPLING EVENT $\ldots \ldots \ldots$. . 3-13

3.2.1 1994 Auger Sample Handling . . . . . . . . . . . . . . . . 3-14

3.2.2 1994 Auger Sample Analysis . . . . . . . . . . . . . 3-15

3.3 DESCRIPTION OF THE 1986 CORE SAMPLING EVENT . . . . . 3-15

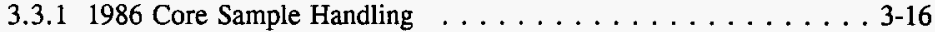

3.3.2 1986 Core Sample Analysis . . . . . . . . . . . . . . . . . 3-16

3.4 GAS MONTTORING $\ldots \ldots \ldots \ldots \ldots \ldots \ldots \ldots \ldots \ldots \ldots \ldots$

4.0 ANALYTICAL RESULTS AND WASTE INVENTORY ESTIMATES . . . . . . . 4-1

4.1 OVERVIEW . . . . . . . . . . . . . . . . . . 4-1

4.2 DATA PRESENTATION . . . . . . . . . . . . . . 4-1

4.3 PHYSICAL MEASUREMENTS . . . . . . . . . . . . . . 4-9

4.3.1 Density, Percent Solids, and Settling Behavior . . . . . . . . 4-9

4.3.2 Thermodynamic Analyses . . . . . . . . . . . . . 4-10

4.3.3 Shear Strength . . . . . . . . . . . . . . 4-10

4.3.4 Shear Stress Versus Shear Rate for Tank 241-SY-103 . . . . . 4-10

4.4 GAS MONITORING $\ldots \ldots \ldots \ldots \ldots \ldots \ldots \ldots \ldots \ldots \ldots \ldots .12$

5.0 INTERPRETATION OF CHARACTERIZATION RESULTS . . . . . . . . . . 5-1

5.1 ASSESSMENT OF SAMPLING AND ANALYTICAL RESULTS $\ldots \ldots$. . 5-1

5.1.1 Field/Laboratory Observations . . . . . . . . . . 5-1 


\section{CONTENTS (Continued)}

5.1.2 Quality Control Assessment of Analytical Data . . . . . . 5-2

5.1.3 Data Consistency Checks ................. 5-3

5.2 COMPARISON OF SAMPLING EVENTS $\ldots \ldots \ldots \ldots \ldots \ldots \ldots$

5.3 TANK WASTE PROFILE $\ldots \ldots \ldots \ldots \ldots \ldots \ldots \ldots \ldots . . . . .5$

5.4 COMPARISON OF ANALYTICAL AND TRANSFER

HISTORY INFORMATTON $\ldots \ldots \ldots \ldots \ldots \ldots \ldots \ldots \ldots$ 5-10

5.5 EVALUATION OF PROGRAM REQUIREMENTS $\ldots \ldots \ldots \ldots \ldots .11$

5.5.1 Safety Evaluation . . . . . . . . . . . . . . . 5-11

5.5 .2 Operational Evaluations $\ldots \ldots \ldots \ldots \ldots \ldots \ldots$. . . . . . . . .

5.5 .3 Environmental Evaluation . . . . . . . . . . . 5-15

5.5.4 Process Development Evaluation . . . . . . . . . 5-15

6.0 CONCLUSION AND RECOMMENDATIONS $\ldots \ldots \ldots \ldots \ldots \ldots$ 6-1

7.0 REFERENCES $\ldots \ldots \ldots \ldots \ldots \ldots \ldots \ldots \ldots \ldots \ldots \ldots \ldots \ldots$

APPENDICES

A 1994 CORE SAMPLING DATA . . . . . . . . . . . . . A-1

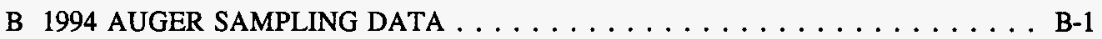

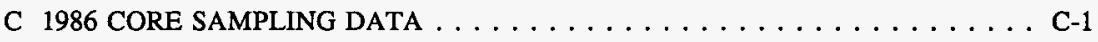

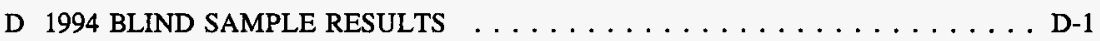




\section{LIST OF FIGURES}

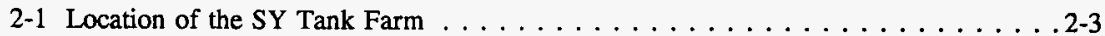

2-2 Riser Configuration for Tank $241-S Y-103 \ldots \ldots \ldots \ldots \ldots \ldots$ 2-5

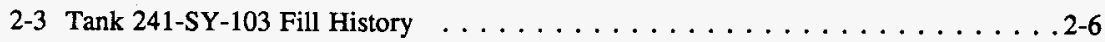

2-4 Tank 241-SY-103 Surface Levels 1981 to $1994 \ldots \ldots$. . . . . . . . . . . . 2-12

2-5 Tank 241-SY-103 Surface Levels June 1989 to June $1993 \ldots \ldots$. . . . . . . . . 23

2-6 Tank 241-SY-103 In-Tank Temperature History . . . . . . . . . . . . . . . . . 2-14

2-7 Tank 241-SY-103 MIT 17B Validation Probe Results $\ldots \ldots \ldots \ldots$. . . . . . . .

4-1 Tank 241-SY-103 Hydrogen Results . . . . . . . . . . . . . . . . . 4-15

4-2 SY Farm Exhaust Stack Ammonia Monitor $\ldots \ldots \ldots \ldots \ldots \ldots$. . . . . . . . . 


\section{LIST OF TABLES}

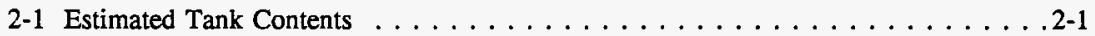

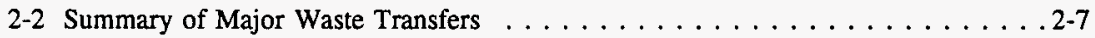

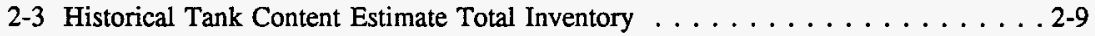

3-1 Tank 241-SY-103 Core 62 Sampling Information $\ldots \ldots \ldots \ldots$. . . . . . . . .

3-2 Tank 241-SY-103 Core 62 Subsampling Information $\ldots \ldots \ldots \ldots . . . . .4$

3-3 Tank 241-SY-103 Core 62 Summary of Subsamples and Analyses . . . . . . . 3-7

3-4 Core 62 Analytical Procedures $\ldots \ldots \ldots \ldots \ldots \ldots \ldots \ldots \ldots \ldots \ldots \ldots \ldots \ldots .11$

3-5 Description of June 1994 Auger Samples $\ldots \ldots \ldots \ldots$. . . . . . . . . . . 3-14

3-6 Tank 241-SY-103 June 1994 Auger Sampling Information . . . . . . . . . . . . 3-14

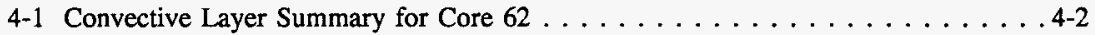

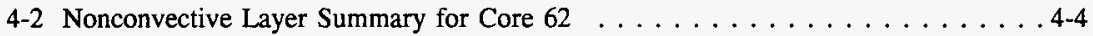

4-3 Tank 241-SY-103 Inventory Based on Core $62 \ldots \ldots \ldots \ldots$. . . . . . . . . .

4-4 Calculated Tank Volumes and Masses $\ldots \ldots \ldots \ldots . . . \ldots$. . . . . . . . . . . .

4-5 Densities of Waste Samples for Core 62, Tank 241-SY-103 . . . . . . . . . 4-9

4-6 Safety Screen Results for Core 62, Tank $241-S Y-103 \ldots \ldots$. . . . . . . . . 4-11

4-7 Tank 241-SY-103 Core 62 Rheological Data . . . . . . . . . . . . . 4-13

4-8 1995 Tank 241-SY-103 Grab Samples . . . . . . . . . . . . . . . . 4-18

5-1 Average Phosphate Concentration $(\mu \mathrm{g} / \mathrm{mL}) \ldots \ldots \ldots \ldots \ldots \ldots \ldots$

5-2 Average Concentration Stratum Samples Selected Elements $(\mu \mathrm{g} / \mathrm{g}) \ldots \ldots \ldots \ldots$ 5-4

5-3 Total Alpha/Specific Isotope Sums $(\mu \mathrm{Ci} / \mathrm{mL}) \ldots \ldots \ldots \ldots \ldots \ldots$ 5-5

5-4 Total Beta/Specific Isotope Sums $\ldots \ldots \ldots \ldots \ldots \ldots \ldots \ldots$ 5-5 $\ldots \ldots \ldots$ 


\section{LIST OF TABLES (Continued)}

5-5 Cation Mass and Charge Data (Stratum $D) \ldots \ldots \ldots \ldots \ldots \ldots \ldots$

5-6 Anion Mass and Charge Data (Stratum D) $\ldots \ldots \ldots \ldots \ldots \ldots$ 5-7

5-7 Mass Balance Totals $\ldots \ldots \ldots \ldots \ldots \ldots \ldots \ldots \ldots \ldots$. . . . . . . . . .

5-8 1986 and 1994 Core Comparison . . . . . . . . . . . . . . . . . 5-8

5-9 Average Concentration $(\mu \mathrm{g} / \mathrm{g})$ Solids $\ldots \ldots \ldots \ldots \ldots \ldots \ldots \ldots$. $\ldots \ldots$

5-10 Tank 241-SY-103 Inventory Comparison $\ldots \ldots \ldots \ldots \ldots \ldots$. . . . . . . . .

5-11 Comparison of Analytical Results with Decision Criteria for the Safety Screening Data Quality Objective $\ldots \ldots \ldots \ldots \ldots$. . . . . . . .

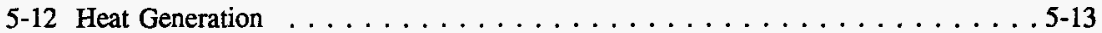

5-13 Evaluation of Organic Fuel Content in Tank 241-SY-103 . . . . . . 5-14 


\section{LIST OF TERMS}

\begin{tabular}{|c|c|}
\hline $\begin{array}{l}\text { Btu/hr } \\
\text { CCPLX }\end{array}$ & $\begin{array}{l}\text { British thermal units per hour } \\
\text { complexant concentrate }\end{array}$ \\
\hline $\mathrm{Ci}$ & curies \\
\hline $\mathrm{cm}$ & centimeters \\
\hline $\mathrm{cm}^{2}$ & square centimeters \\
\hline $\mathrm{cm}^{3}$ & cubic centimeters \\
\hline $\mathrm{cP}$ & centipoise \\
\hline DSC & differential scanning calorimetry \\
\hline DSS & double-shell slurry \\
\hline DQO & data quality objective \\
\hline $\mathrm{ft}$ & feet \\
\hline g & grams \\
\hline gal & gallons \\
\hline $\mathrm{HHF}$ & hydrostatic head fluid \\
\hline IC & ion chromagraphy \\
\hline ICP & Inductively coupled plasma \\
\hline in. & inches \\
\hline $\mathrm{kg}$ & kilograms \\
\hline $\mathrm{kgal}$ & kilogallons \\
\hline $\mathrm{kL}$ & kiloliters \\
\hline $\mathrm{kW}$ & kilowatts \\
\hline J & joules \\
\hline $\mathrm{L}$ & liters \\
\hline LEL & low explosive limit \\
\hline LFL & lower flammability limit \\
\hline $\mathrm{m}$ & meters \\
\hline $\mathrm{mg}$ & milligram \\
\hline $\min$ & minute \\
\hline $\mathrm{mL}$ & milliliter \\
\hline $\mathbf{M}$ & molarity \\
\hline $\mathrm{nCi}$ & nanocuries \\
\hline $\mathrm{Pa}$ & Pascal \\
\hline ppm & parts per million \\
\hline ppmv & parts per million volume \\
\hline RPD & relative percent difference \\
\hline $\mathrm{R} / \mathrm{hr}$ & roentgen per hour \\
\hline TIC & total inorganic carbon \\
\hline TOC & total organic carbon \\
\hline $\mathrm{W}$ & Watts \\
\hline$w t \%$ & weight percent \\
\hline${ }^{\circ} \mathrm{C}$ & degrees Celsius \\
\hline${ }^{\circ} \mathrm{F}$ & degrees Fahrenheit \\
\hline
\end{tabular}


WHC-SD-WM-ER-471 Rev. 1

\section{LIST OF TERMS (Continued)}

$$
\begin{aligned}
& \mu \mathrm{Ci} \\
& \mu \mathrm{g} \\
& \mu \mathrm{mol} / \mathrm{g} \\
& \mathrm{V} / \mathrm{V}
\end{aligned}
$$

microcuries

micrograms

micromoles per gram

volume/volume dilution ratio 
WHC-SD-WM-ER-471 Rev. 1

This page intentionally left blank. 


\subsection{INTRODUCTION}

This tank characterization report provides an overview of the history and waste contents of double-shell tank 241-SY-103. It includes historical data and information about the tank and its contents and estimates of concentrations and inventories for waste components based on the most recent analytical data. The tank contents were sampled and analyzed in 1986 and in 1994. A comparison of the historical information with the 1994 analytical data is provided. The report supports the requirements of the Hanford Federal Facility Agreement and Consent Order (Ecology et al. 1996), Milestone M-44-09.

\subsection{PURPOSE}

The purpose of this report is to summarize historical information about tank use and to estimate its contents. When possible, the information will be used to assess issues associated with safety, operations, environmental issues, and process development activities.

References to additional technical information about the tank and its contents are also provided.

\subsection{SCOPE}

Before core sampling tank 241-SY-103, auger sampling of the tanks crust was performed in support of the Data Requirements Developed Through the Data Quality Objectives Process for the Crust Burn Issue Associated with Flammable Gas Tanks (Johnson 1994).

The 1994 sampling centered on safety concerns and the need for data on fundamental chemical, radiological, and physical properties of the tank waste. Push-mode core samples were taken in August and September of 1994 for support of the Tank Safety Screening Data Quality Objective (DQO) (Babad and Redus 1994), and the Flammable Gas Tank Safety Programs: Data Requirements for Core Sample Analysis Developed Through the Data Quality Objective (DQO) Process (McDuffie and Johnson 1994). The data gathered for the flammable gas DQO were intended to provide insight on the mechanisms of gas generation, retention, and release. In addition, gas behavior in the tank was to be modeled to support safety analysis and development of mitigation methods. Discussion of gas generation, retention, and release mechanisms and mitigation efforts is outside the scope of this report.

Many of the requirements for the safety screen DQO are similar to the flammable gas DQO. Data to support waste energetics, criticality, and tank vapor flammability were generated in the 1994 core sampling event. The measurements performed in the 1994 sampling event are described in Section 3.0. 
The goal of the 1986 tank sampling was to determine the physical, theological, chemical, and radiochemical properties of the tank waste before transferring it to tank 241-AP-107. This transfer did not take place. Pre-May 1989 data should not be used for decision making because adequate quality control information is not available for assessing data quality. 


\subsection{HISTORICAL TANK INFORMATION}

Tank 241-SY-103 is in restricted service as a result of safety concerns related to hydrogen gas generation. The current tank status is available in routinely updated reports (Hanlon 1995). This section provides information about tank design, waste transfer history, waste temperature, and surface level.

\subsection{TANK STATUS}

According to Hanlon (1996), tank 241-SY-103 contains the volumes of waste shown in Table 2-1. As in tank 241-SY-101, three layers are expected: crust, convective, and nonconvective layers (Fox et al. 1993 and Schreiber 1994b). The tank integrity is sound, and it is in service. However, tank operations are restricted because the tank is on the Flammable Gas Watch List and has an associated unreviewed safety question.

Table 2-1. Estimated Tank Contents.

\begin{tabular}{|c|c|c|}
\hline $\operatorname{ry}$ & . & \\
\hline Waste Fom & Kiloliter & Kulogallons \\
\hline Total waste & 2,824 & 746 \\
\hline Supernatant liquid & 640 & 160 \\
\hline DSS & 2,169 & 573 \\
\hline Sludge & 0 & 0 \\
\hline Saltcake & 15 & 4 \\
\hline Drainable interstitial liquid & 0 & 0 \\
\hline Drainable liquid remaining & 640 & 169 \\
\hline Pumpable liquid remaining & 640 & 169 \\
\hline
\end{tabular}

Note:

${ }^{1}$ For definitions and calculation methods, refer to Appendix C (Hanlon 1996).

Tank 241-SY-103 is equipped with an automated liquid surface-level gauge and a manual tape. (The manual tape was out of service when the 1995 Hanlon report was compiled.) 
The waste depth is approximately $6.88 \mathrm{~m}(22.58 \mathrm{ft})$. Except for the manual tape, all monitoring systems are in compliance with established standards. For information about waste levels and temperatures, see Section 2.4 .

Most tank 241-SY-103 waste is complexant concentrate (CCPLX) and double-shell slurry (DSS), concentrated process streams associated with waste tank flammable gas safety issues (WHC 1994 and McDuffie and Johnson 1994). Tank 241-SY-103 has been on the Flammable Gas Watch List since January 1991 (Hanlon 1995). A standard hydrogen monitoring system was installed in June 1994. Flammable gas is believed to be generated in the tank waste in quantities that may accumulate to levels approaching the LFL of hydrogen in air or hydrogen in nitrous oxide (Fox et al. 1993). An unreviewed safety question has been declared because a fuel (hydrogen) and an oxidizer (nitrous oxide) may coexist in the waste mass. A related safety issue is a concern that a chemical reaction could occur in the crust layer (crust burn) as a result of gas burn or intrusive activities (Schreiber 1994a).

\subsection{TANK DESIGN}

Tank 241-SY-103 is one of three double-shell tanks that comprise the SY Tank Farm. The SY Tank Farm contains the only double-shell tanks in the 200 West Area of the Hanford Site (see Figure 2-1). The tanks, which were designed to hold concentrated waste, were completed in 1977. For more information about the SY Tank Farm and double-shell tanks, refer to the Tank Characterization Reference Guide (De Lorenzo et al. 1994).

Like other double-shell tanks, tank 241-SY-103 was fabricated as three concentric tanks consisting of two steel liners within a protective concrete shell (see Figure ES-1). The protective shell is constructed of reinforced concrete designed to sustain soil loads and temperature gradients generated by the contained radioactive waste (WHC 1994). The inner wall of the concrete shell is lined with a carbon-steel liner called the secondary tank. The primary tank, also constructed of carbon steel, is completely enclosed within the secondary tank. The primary tank is freestanding. It sits on an insulating concrete pad that protects the structural concrete foundation from excessive temperatures during the annealing treatment, or stress relief, of the primary tank. The insulating pad is cast with air distribution and drain grids to provide leak detection, maintain a uniform tank bottom temperature, facilitate heat removal, and eliminate pockets of water condensation. An annular space, which separates the two steel liners, is a containment barrier to any primary tank leaks. The tanks are actively vented to the environment through high-efficiency particulate air filters. The primary ventilation system removes vapors from the primary tank and maintains negative pressure in relation to the atmosphere. The annulus ventilation system cools the primary tank, removes moisture from annular space, and helps detect radioactive leaks.

Tank 241-SY-103 has a maximum storage capacity of 4,390 $\mathrm{kL}(1,160 \mathrm{kgal})$ and a nominal capacity of $4,370 \mathrm{~kL}(1,150 \mathrm{kgal}$ ) (WHC 1994). It has an inside diameter of $22.9 \mathrm{~m}(75 \mathrm{ft}$ ), and it is $14.2 \mathrm{~m}$ (46 $\mathrm{ft} 9 \mathrm{in}$ ) high at the crown. 
Figure 2-1. Location of the SY Tank Farm.

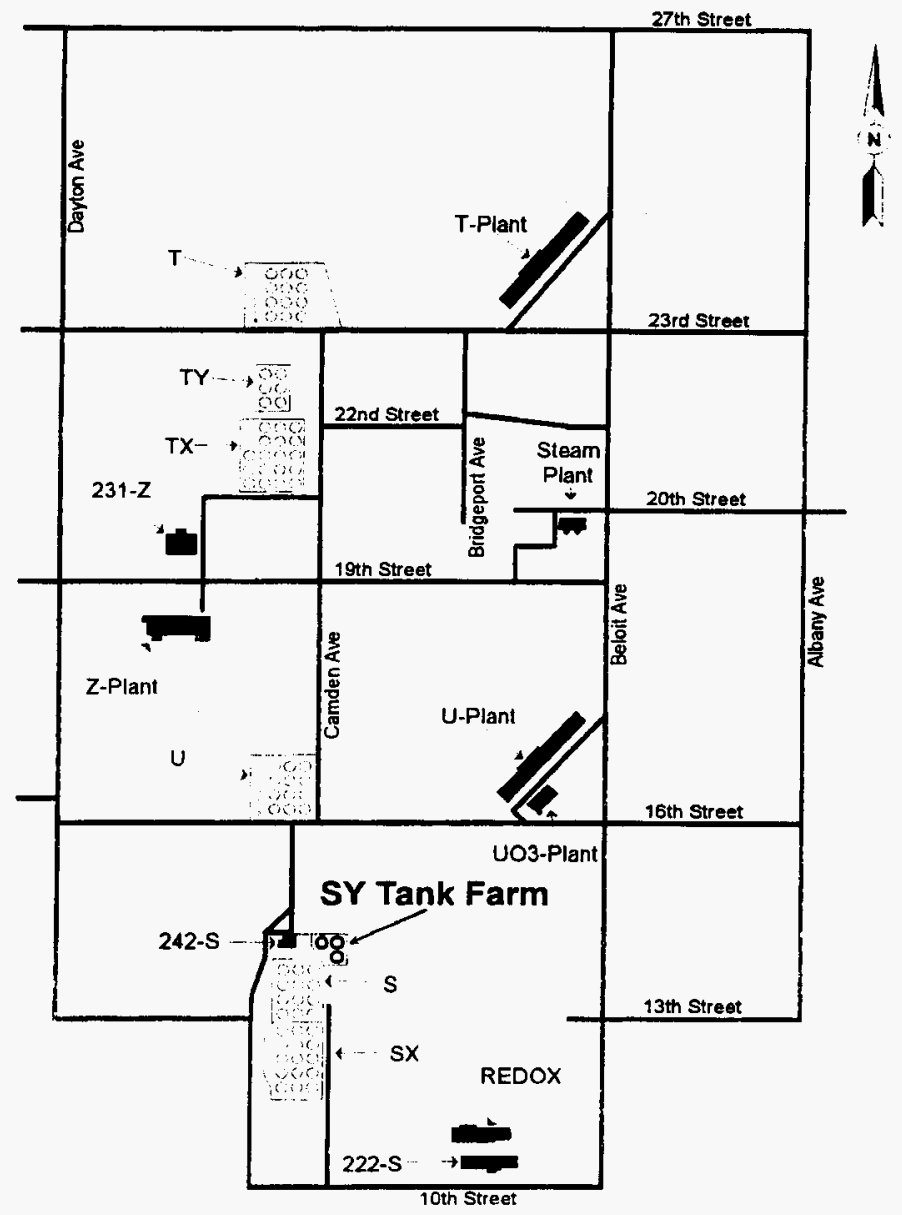


Tank 241-SY-103 has 24 risers that penetrate the primary tank dome and provide access for waste transfers, sampling, tank monitoring, and ventilation. Additional risers access the annulus (DOE 1994). Instruments monitor the pressure, temperature, liquid level, sludge level, and other bulk tank characteristics. Waste has been added and removed through risers that enter tank 241-SY-103 through the central pump pit. Riser locations are shown in Figure 2-2. For additional riser information, see Anderson (1992).

\subsection{PROCESS KNOWLEDGE}

Tank 241-SY-103 began operating in 1977 and received concentrated wastes. Two years later the tank contained more than $3,600 \mathrm{~kL}$ ( $950 \mathrm{kgal}$ ) of CCPLX waste. During 1980, the tank was pumped down to a waste heel of about $466 \mathrm{~kL}$ (123 kgal), then received DSS. During 1985, the tank received small transfers of uranium ion exchange sludge. The uranium sludge was generated from groundwater pumped from beneath a crib near U-Plant, then processed through ion-exchange resins. During 1988 and 1989, the tank received saltwell liquid and waste water from the 200 West Area. For additional information on the waste transfer history of the tank, see Section 2.3.1.

Since 1979, waste level fluctuations in tank 241-SY-103 have been observed at times when waste was not added or removed from the tank (Welty 1988). The fluctuations are attributed to the accumulation and release of gases, mainly hydrogen (gas release events). Tank 241-SY-103 contains waste forms that are similar to the constituents in tank 241-SY-101. Both tanks generate and house accumulated gases. This phenomenon is shown by rising surface levels followed by periodic gas releases and subsequent surface level drops. From January 1989 to July 1993, 12 gas release events were observed in tank 241-SY-103 with an average period between events of 135 days (Fox et al. 1993). During these events, surface level decreases were measured ranging from $1.8 \mathrm{~cm}(0.7$ in.) to $5.8 \mathrm{~cm}$ (2.3 in.). Unlike tank 241-SY-101, which has experienced much larger releases historically, the pressure in the headspace of tank 241-SY-103 remained below atmospheric pressure for each event. Since 1990, the period between gas release events appears to be increasing with the longest period being 302 days. This may be the result of cooling temperatures in the tank. Prior to 1985, waste level fluctuations in tank 241-SY-103 were random (Harmon 1993). In the latter half of 1985, after uranium ion-exchange wastes were pumped into the tank, the magnitude of the surface level fluctuations appeared to increase.

Figure 2-3 shows the fill history of the tank based on information from Agnew et al. (1995), Anderson (1990), Fox et al. (1993), and Harmon (1993). The estimated amount of each major waste type added to the tank during its process history is shown in Table 2-2. 
Figure 2-2. Riser Configuration for Tank 241-SY-103.

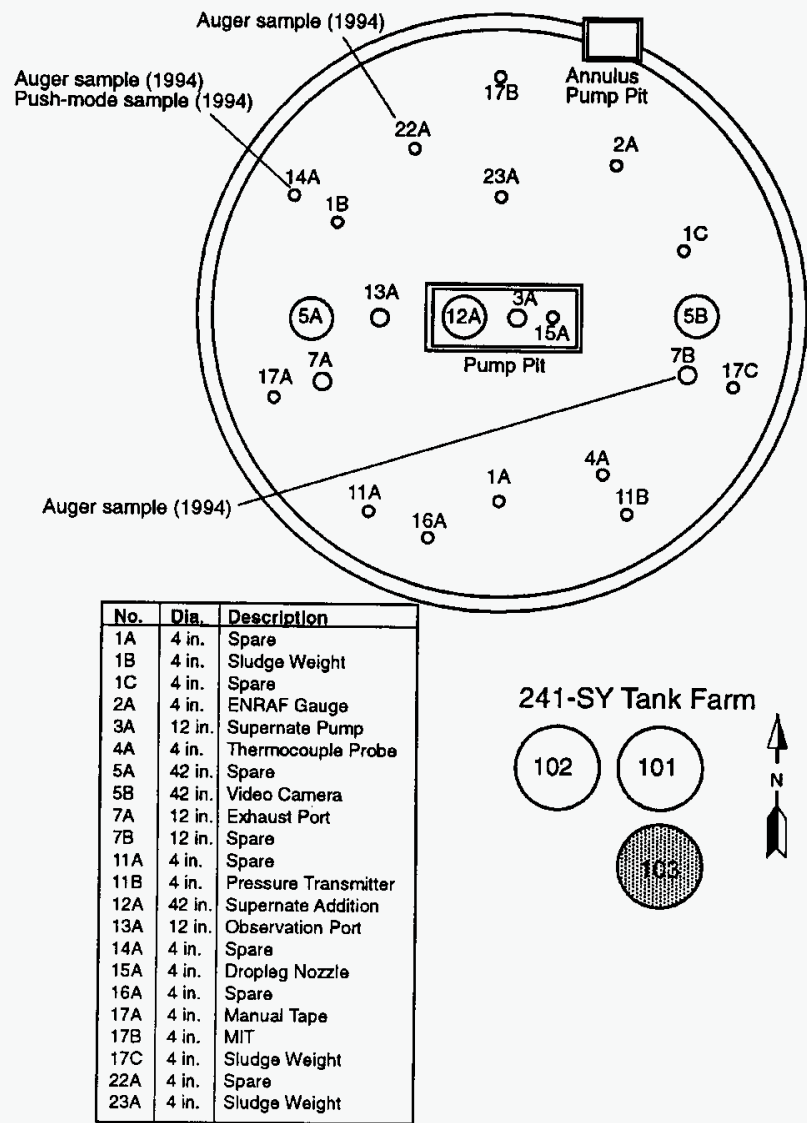

2G95100626.1 
Figure 2-3. Tank 241-SY-103 Fill History.

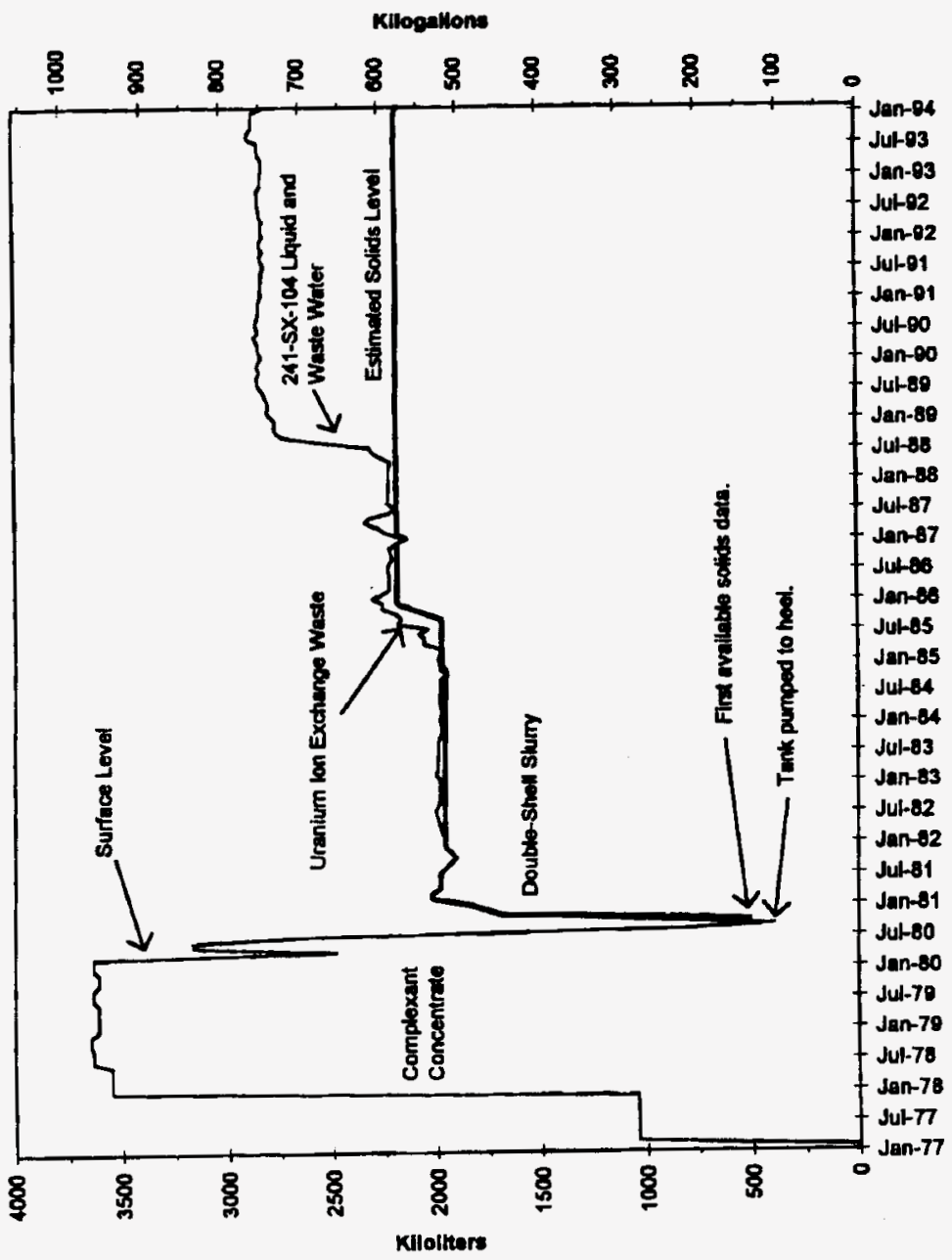


Table 2-2. Summary of Major Waste Transfers ${ }^{1}$.

\begin{tabular}{|c|c|c|}
\hline Woste Type & Terod hereired & 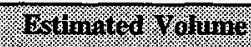 \\
\hline Complexant concentrate ${ }^{2}$ & 1977 to 1980 & $466^{3} \mathrm{~kL}(123 \mathrm{kgal})$ \\
\hline Double-shell slurry & 1980 & $1,590 \mathrm{~kL}(420 \mathrm{kgal})$ \\
\hline Uranium ion exchange eluate & 1985 & $121 \mathrm{~kL}(32 \mathrm{kgal})$ \\
\hline Tank 241-SX-104 supernate & 1981 to 1989 & $496 \mathrm{~kL}$ (131 kgal) \\
\hline
\end{tabular}

Notes:

'Volumes are from Fox et al. (1993).

${ }^{2} \mathrm{CCPLX}$ also includes B Plant high strontium waste and evaporator residual liquor.

${ }^{3}$ The estimated CCPLX volume represents the heel remaining in the tank after most CCPLX was removed.

\subsubsection{Waste Transfer History}

During 1977 to 1979 , tank 241-SY-103 received concentrated wastes from B Plant cesium and strontium recovery campaigns (Anderson 1990 and Agnew et al. 1995). This waste, CCPLX and residual evaporator liquid, is rich in complexing agents such as sodium salts of ethylenediaminetetraacetate (EDTA) and glycolic acid (Agnew 1995).

Most of the CCPLX waste was transferred from the tank in 1980 leaving a heel of about $466 \mathrm{~kL}$ (123 kgal) (Agnew et al. 1995). During 1980, about 1,590 kL (420 kgal) of DSS was received from the 242-S Evaporator (Fox et al. 1993). The DSS is the most concentrated product produced by Hanford Site evaporators (Strode et al. 1988). This waste was concentrated beyond the aluminate solubility boundary. It is highly viscous and has high concentrations of hydroxide, nitrate, carbonate, and aluminate (Agnew 1995).

Other than small amounts of water, no other transfers involving this tank occurred until 1985. From June to November of 1985 , approximately $121 \mathrm{~kL}$ (32 kgal) of uranium sludge from ion-exchange processing were placed on top of the DSS. This waste consisted of a solution of sodium nitrate and sodium hydroxide that contained about $690 \mathrm{~kg}$ of uranium (Fox et al, 1993).

There have been no transfers from tank 241-SY-103 since January 1981. However, between 1981 and 1989, small additions of waste water were made from catch tanks, sumps, and evaporator flushes as well as saltwell liquid from single-shell tanks (Agnew et al. 1995 and Fox et al. 1993). The most significant waste addition after the 1985 uranium sludge transfer 
was approximately $496 \mathrm{~kL}$ (131 kgal) of liquid waste from the saltwell pumping of tank 241-SX-104 from 1988 to 1989 (Fox et al. 1993). Tank 241-SX-104 was storing DSS feed at the time of the pumping. No waste has been added since 1990 (Koreski 1995).

\subsubsection{Historical Estimate of Contents}

Tank inventory estimates based on the tank layer model, waste status and transaction record summary, and Hanford defined waste types, have been developed for tank 241-SY-103 by the Los Alamos National Laboratory (Brevick 1995). Table 2-3 shows the historical tank content estimate based on the supernatant mixing model (Brevick 1995). Table 2-3 data are shown as model predictions only and are not intended to be used for decision-making for the waste in tank 241-SY-103.

Waste, which was added to the tank at various times, has settled into layers that vary from sludge (lower depths) to liquid (toward the top). From the bottom up, the solids in the lowest region are expected to consist of the following: a heel of CCPLX from the early process history, DSS, and uranium ion-exchange sludge. A less dense layer of supernate is on top of the solids layer; it consists of waste water and other liquid waste transfers. Sampling confirms the existence of a crust layer at the waste surface (Schreiber 1994b). Similar to tank 241-SY-101 waste, the solid layers of waste on the tank 241-SY-103 bottom appear to be nonconvective, and the supernate region farther up appears to be convective so that the waste appears to circulate naturally (Fox et al. 1993).

Based on the process history of tank 241-SY-103, the following assumptions can be made about its major waste constituents. The lower regions of waste are expected to contain large amounts of organic complexants from the CCPLX heel left in the tank in 1980. Large concentrations of aluminate are expected from the DSS, the predominant waste type in the tank. 
Table 2-3. Historical Tank Content Estimate Total Inventory. ${ }^{1,2}$ (2 sheets)

\begin{tabular}{|c|c|c|c|}
\hline 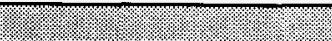 & \multicolumn{3}{|c|}{ 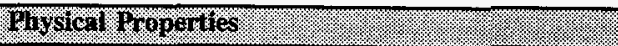 } \\
\hline Total waste & \multicolumn{3}{|c|}{$4.21 \mathrm{E}+6 \mathrm{~kg}(758 \mathrm{kgal})$} \\
\hline Heat load & \multicolumn{3}{|c|}{$5.36 \mathrm{~kW}(1.83 \mathrm{E}+4 \mathrm{Btu} / \mathrm{hr})$} \\
\hline Bulk density ${ }^{3}$ & \multicolumn{3}{|c|}{$1.47 \mathrm{~g} / \mathrm{cm}^{3}$} \\
\hline Water wt $\%^{3}$ & \multicolumn{3}{|c|}{$45.7 w t \%$} \\
\hline TOC wt $\%$ carbon (wet) ${ }^{3}$ & \multicolumn{3}{|c|}{1.08 wt\% carbon } \\
\hline 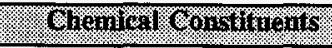 & \%ologer. & 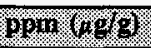 & . \\
\hline $\mathrm{Na}^{+}$ & 9.94 & $1.56 \mathrm{E}+5$ & $6.56 \mathrm{E}+5$ \\
\hline$\overline{\mathrm{Al}^{3+}}$ & 1.40 & $2.56 \mathrm{E}+4$ & $1.08 \mathrm{E}+5$ \\
\hline $\mathrm{Fe}^{3+}($ total $\mathrm{Fe})$ & $2.74 \mathrm{E}-3$ & $1.04 \mathrm{E}+2$ & $4.40 \mathrm{E}+2$ \\
\hline $\mathrm{Cr}^{3+}$ & $3.21 \mathrm{E}-2$ & $1.14 \mathrm{E}+3$ & $4.79 \mathrm{E}+3$ \\
\hline $\mathrm{Bi}^{3+}$ & $1.61 \mathrm{E}-3$ & $2.29 \mathrm{E}+2$ & $9.64 \mathrm{E}+2$ \\
\hline $\mathrm{La}^{3+}$ & $1.48 \mathrm{E}-5$ & 1.40 & 5.91 \\
\hline $\mathrm{Hg}^{2+}$ & $9.81 \mathrm{E}-6$ & 1.34 & 5.65 \\
\hline $\mathrm{Zr}$ [as $\left.\mathrm{ZrO}(\mathrm{OH})_{2}\right]$ & $9.84 \mathrm{E}-4$ & $6.11 \mathrm{E}+1$ & $2.58 \mathrm{E}+2$ \\
\hline $\mathrm{Pb}^{2+}$ & $4.85 \mathrm{E}-5$ & 6.84 & $2.88 \mathrm{E}+1$ \\
\hline $\mathrm{Ni}^{2+}$ & $2.39 \mathrm{E}-3$ & $9.54 \mathrm{E}+1$ & $4.02 \mathrm{E}+2$ \\
\hline $\mathrm{Sr}^{2+}$ & $1.57 \mathrm{E}-5$ & $9.36 \mathrm{E}-1$ & 3.94 \\
\hline $\mathrm{Mn}^{4+}$ & $8.08 \mathrm{E}-3$ & $3.02 \mathrm{E}+\overline{2}$ & $1.27 \mathrm{E}+3$ \\
\hline $\mathrm{Ca}^{2+}$ & $1.92 \mathrm{E}-2$ & $5.24 \mathrm{E}+2$ & $2.21 \mathrm{E}+3$ \\
\hline $\mathrm{K}^{+}$ & $2.40 \mathrm{E}-2$ & $6.39 \mathrm{E}+2$ & $2.69 \mathrm{E}+3$ \\
\hline $\mathrm{OH}^{-}$ & 6.06 & $7.01 \mathrm{E}+4$ & $2.95 \mathrm{E}+5$ \\
\hline $\mathrm{NO}_{3}^{-}$ & 3.00 & $1.27 \mathrm{E}+5$ & $5.34 \mathrm{E}+5$ \\
\hline $\mathrm{NO}_{2}^{-}$ & 2.84 & $8.90 \mathrm{E}+4$ & $3.75 E+5$ \\
\hline $\mathrm{CO}_{3}^{2-}$ & $3.69 \mathrm{E}-1$ & $1.51 \mathrm{E}+4$ & $6.36 \mathrm{E}+4$ \\
\hline $\mathrm{PO}_{4}^{3-}$ & $1.34 \mathrm{E}-1$ & $8.66 \mathrm{E}+3$ & $3.65 \mathrm{E}+4$ \\
\hline $\mathrm{SO}_{4}^{2-}$ & $2.81 \mathrm{E}-1$ & $1.84 \mathrm{E}+4$ & $7.76 \mathrm{E}+4$ \\
\hline $\mathrm{Si}$ (as $\mathrm{SiO}_{3}^{2-}$ ) & $4.06 \mathrm{E}-2$ & $7.77 E+2$ & $3.27 \mathrm{E}+3$ \\
\hline $\mathrm{F}^{-}$ & $9.67 \mathrm{E}-2$ & $1.25 \mathrm{E}+3$ & $5.27 \mathrm{E}+3$ \\
\hline $\mathrm{Cl}^{-}$ & $1.70 \mathrm{E}-1$ & $4.11 \mathrm{E}+3$ & $1.73 E+4$ \\
\hline citrate $^{3-}$ & $3.45 \mathrm{E}-2$ & $4.45 \mathrm{E}+3$ & $1.87 \mathrm{E}+4$ \\
\hline EDTA $^{4-}$ & $2.15 \mathrm{E}-2$ & $4.22 E+3$ & $1.78 \mathrm{E}+4$ \\
\hline HED'TA $^{3-}$ & $3.84 \mathrm{E}-2$ & $7.17 E+3$ & $3.02 \mathrm{E}+4$ \\
\hline
\end{tabular}


Table 2-3. Historical Tank Content Estimate Total Inventory. ${ }^{1,2}$ (2 sheets)

\begin{tabular}{|c|c|c|c|}
\hline 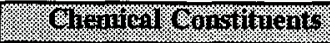 & mol\% & poin $(1 / 9)$ & xy \\
\hline glycolate $^{-}$ & $1.04 \mathrm{E}-1$ & $5.31 \mathrm{E}+3$ & $2.24 E+4$ \\
\hline acetate $^{-}$ & $1.48 \mathrm{E}-2$ & $5.95 \mathrm{E}+2$ & $2.51 \mathrm{E}+3$ \\
\hline oxalate $^{2-}$ & $5.60 \mathrm{E}-5$ & 3.36 & $1.41 \mathrm{E}+1$ \\
\hline$\overline{\mathrm{DBP}}$ & $1.64 \mathrm{E}-2$ & $1.80 \mathrm{E}+3$ & $7.57 \mathrm{E}+3$ \\
\hline butanol & $1.64 \mathrm{E}-2$ & $8.27 \mathrm{E}+2$ & $3 . \overline{48 E+3}$ \\
\hline $\mathrm{NH}_{3}$ & $4.69 \mathrm{E}-2$ & $5.43 \mathrm{E}+2$ & $2.29 \mathrm{E}+3$ \\
\hline $\mathrm{Fe}(\mathrm{CN})_{6}^{4-}$ & 0 & 0 & 0 \\
\hline & \multicolumn{2}{|c|}{ 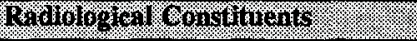 } & \\
\hline $\mathrm{Pu}^{(4)}$ & $2.52 \mathrm{E}-2(\mu \mathrm{Ci} / \mathrm{g})$ & - & $1.77(\mathrm{~kg})$ \\
\hline $\mathrm{U}^{(4)}$ & $5.20 \mathrm{E}-3(\mathrm{M})$ & $843(\mu \mathrm{g} / \mathrm{g})$ & $3.55 \mathrm{E}+3(\mathrm{~kg})$ \\
\hline${ }^{137} \mathrm{Cs}$ & $0.386(\mathrm{Ci} / \mathrm{L})$ & $263(\mu \mathrm{Ci} / \mathrm{g})$ & $1.11 \mathrm{E}+6(\mathrm{Ci})$ \\
\hline${ }^{90} \mathrm{Sr}$ & $8.76 \mathrm{E}-3(\mathrm{Ci} / \mathrm{L})$ & $5.97(\mu \mathrm{Ci} / \mathrm{g})$ & $2.51 \mathrm{E}+4(\mathrm{Ci})$ \\
\hline
\end{tabular}

Notes:

'From Brevick (1995); the table data are shown as model predictions only and are not intended to be used for decision-making about the waste in tank 241-SY-103.

${ }^{2}$ Unknowns in tank solids inventory are assigned by the tank layer model (Agnew et al. 1995).

${ }^{3}$ Density was computed on a volume average; water weight percent and TOC weight percent carbon were computed on a mass average.

${ }^{4}$ Brevick (1995) does not indicate isotopic composition for plutonium or uranium. However, ${ }^{239240} \mathrm{Pu}$ and ${ }^{238} \mathrm{U}$ are the predominate isotopes based on process knowledge.

\subsection{SURVEILLANCE DATA}

\subsubsection{Surface Level Readings}

The waste surface level in tank 241-SY-103 is measured with an automated ENRAF gauge and a manual tape (currently out of service) (Hanlon 1995). Surface level measurements are recorded daily. The ENRAF gauge went into service in July 1994 to replace a Food Instrument Corporation gauge (De Lorenzo et al. 1994). The ENRAF gauge determines the waste surface level by detecting variations in the weight of a displacer (a small disk) suspended in the tank through a riser (Hanlon 1995). The displacer, which is suspended on the end of wire wound onto a precision measuring drum, is lowered until a force transducer detects a change in the weight of the displacer, indicating contact with the waste surface has 
been made. The manual tape uses a conductivity electrode that is lowered until contact is established with the waste surface, indicated by the completion of an electrical circuit.

According to data from the Surveillance Analysis Computer System, the ENRAF gauge

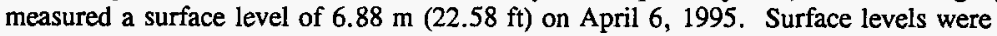
measured by the Food Instrument Corporation and ENRAF gauges from 1981 through 1994 (see Figure 2-4). A closer examination of data from 1989 through 1993 shows a distinct saw-toothed pattern of gas accumulation and release (see Figure 2-5). The current surface level is not expected to be equal to the sum of all the major and minor waste additions over the process history of the tank because of the cycles of slurry growth and subsequent gas releases. In addition, the surface level is also affected by evaporation and condensation processes (Fox et al. 1993).

\subsubsection{Internal Tank Temperatures}

Temperatures in tank 241-SY-103 are measured by thermocouple probes assembled in a tree

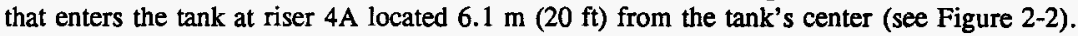
The lowest-elevation operational thermocouple (thermocouple 2) is $23 \mathrm{~cm}$ ( 9 in.) above the tank bottom; other thermocouples are spaced at 61-cm (24-in.) intervals (Tran 1993). The thermocouples are iron-constantan type $\mathrm{J}$ with an average error of $\pm 2.5^{\circ} \mathrm{C}\left(4.5^{\circ} \mathrm{F}\right)$ (Scaief 1991). The maximum in-tank temperature on April 6, 1995 was $34.4^{\circ} \mathrm{C}\left(94^{\circ} \mathrm{F}\right.$ ) measured at thermocouple 3 . Waste temperatures recorded by thermocouples 2,4 , and 6 indicate the waste is cooling (Fox et al. 1993). A least squares linear fit of average temperatures from these three thermocouples indicates a cooling rate of $2.7^{\circ} \mathrm{C}\left(4.86^{\circ} \mathrm{F}\right)$ per year. The highest temperature ever recorded in the tank was $47.2{ }^{\circ} \mathrm{C}\left(117^{\circ} \mathrm{F}\right)$ at thermocouple 2 in May 1991. In-tank temperatures have remained within operating and design specifications (WHC 1994).

Figure 2-6 shows temperatures recorded from thermocouples 2, 6, and 12 from January 1991 to December 1994. The tank waste regions measured by the thermocouples are not well defined. However, examination of data from previous core sampling and temperature histories indicates thermocouple 2 is probably within the nonconvective region, thermocouple 6 may be within the lower part of the convective layer, and thermocouple 12 is probably within the crust layer (Fox et al. 1993). The relationship of the temperature readings from thermocouples 6 and 12 in recent years suggests both are near the temperature of the convective region, which was not the case prior to 1991 . The crust layer may have been thicker at that time, providing additional heat flow resistance for heat traveling to the dome air. After the last date (October 1994) on Figure 2-6, thermocouple 12 acts like a vapor space temperature and doesn't follow thermocouple 6 as closely. Thermocouple 12 elevation is about the same as the waste level.

A Multifunctional Instrument Tree in riser $17 \mathrm{~B}$ measures temperatures (with type $\mathrm{K}$ thermocouples). The peak temperature measured is approximately $100^{\circ} \mathrm{F}$. The convective layer is approximately $90^{\circ} \mathrm{F}$. This is comparable to those measured in riser $4 \mathrm{~A}\left(98^{\circ} \mathrm{F}\right.$ 
Figure 2-4. Tank 241-SY-103 Surface Levels 1981 to 1994.

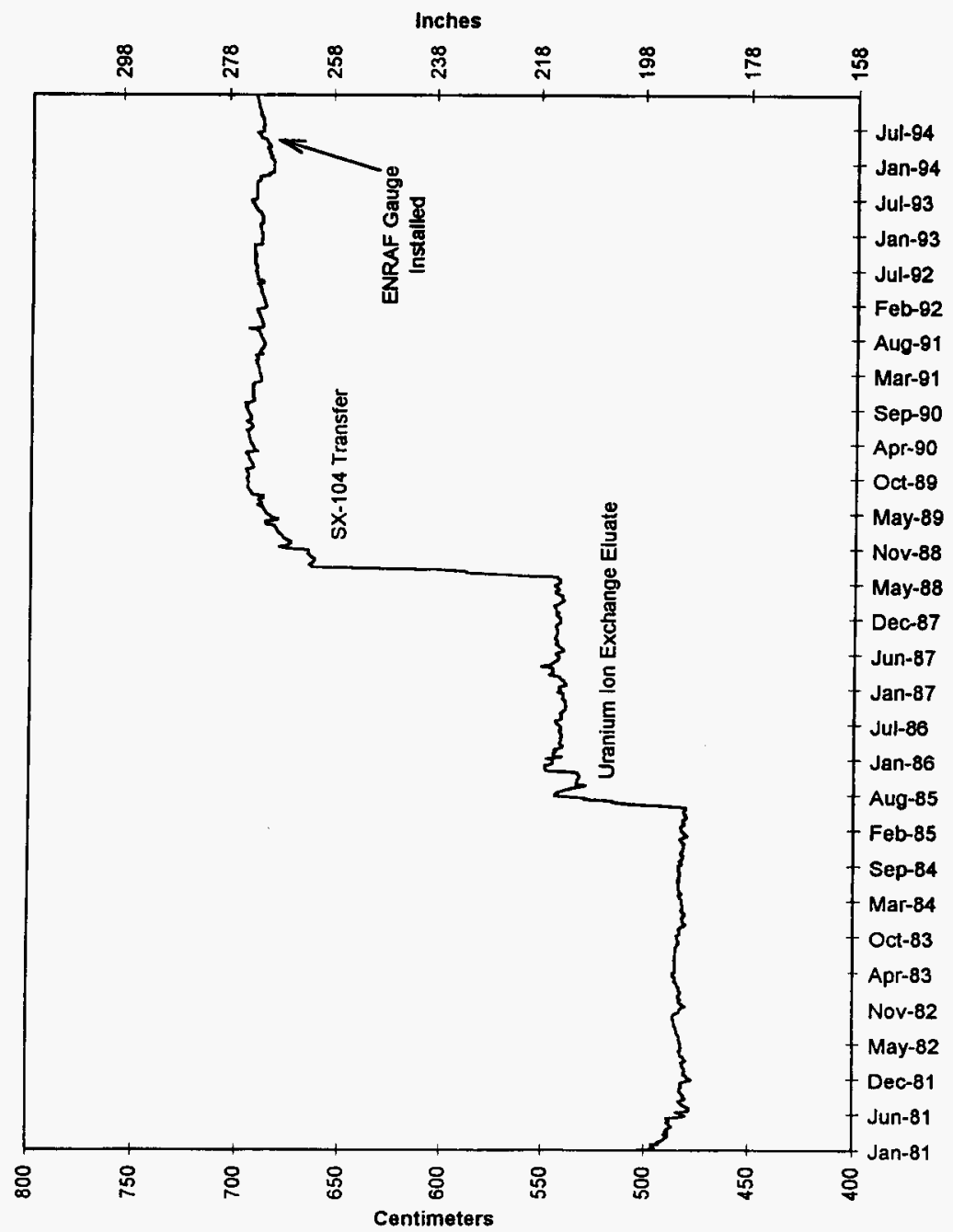


Figure 2-5. Tank 241-SY-103 Surface Levels June 1989 to June 1993.

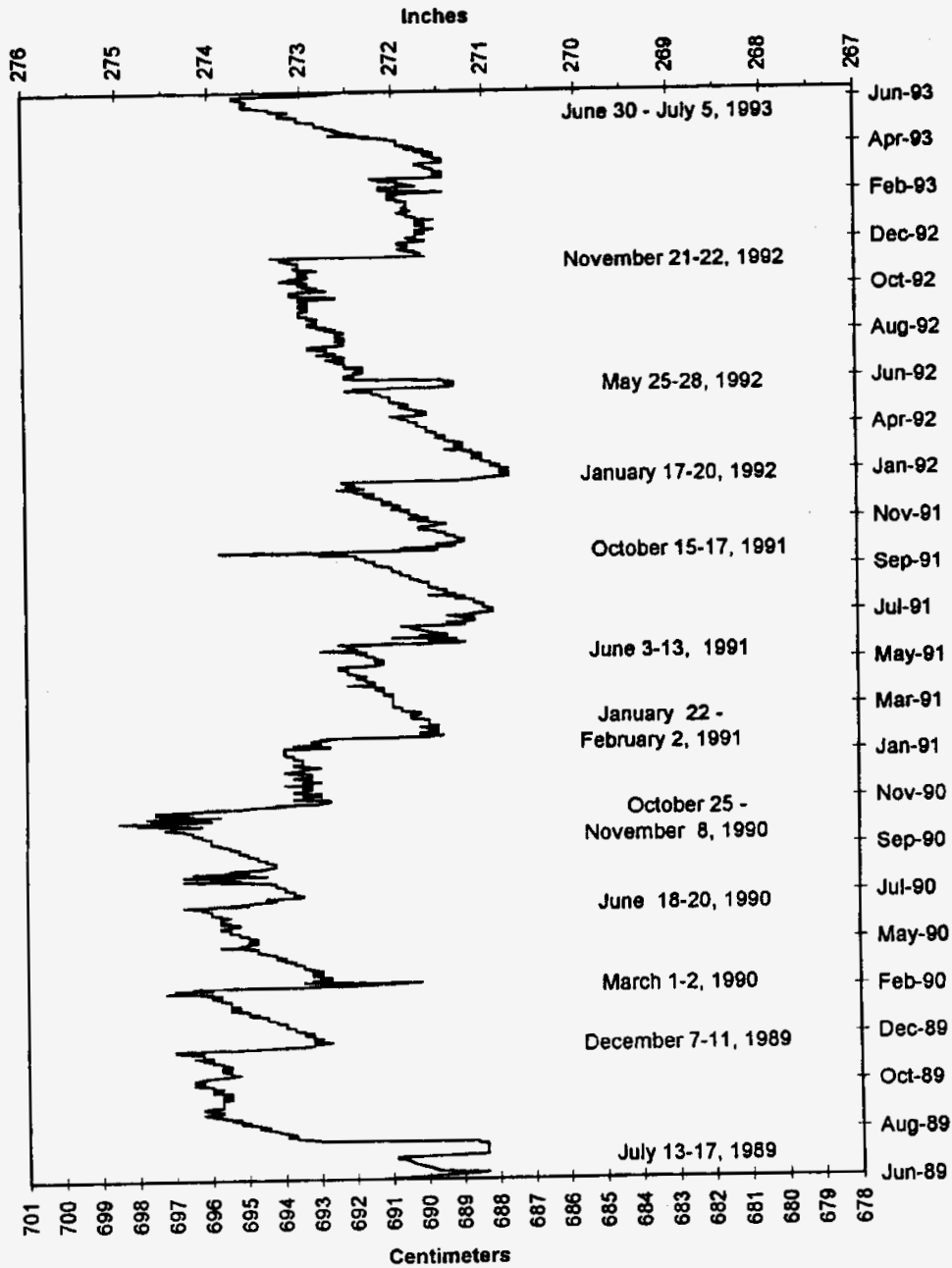


Figure 2-6. Tank 241-SY-103 In-Tank Temperature History.

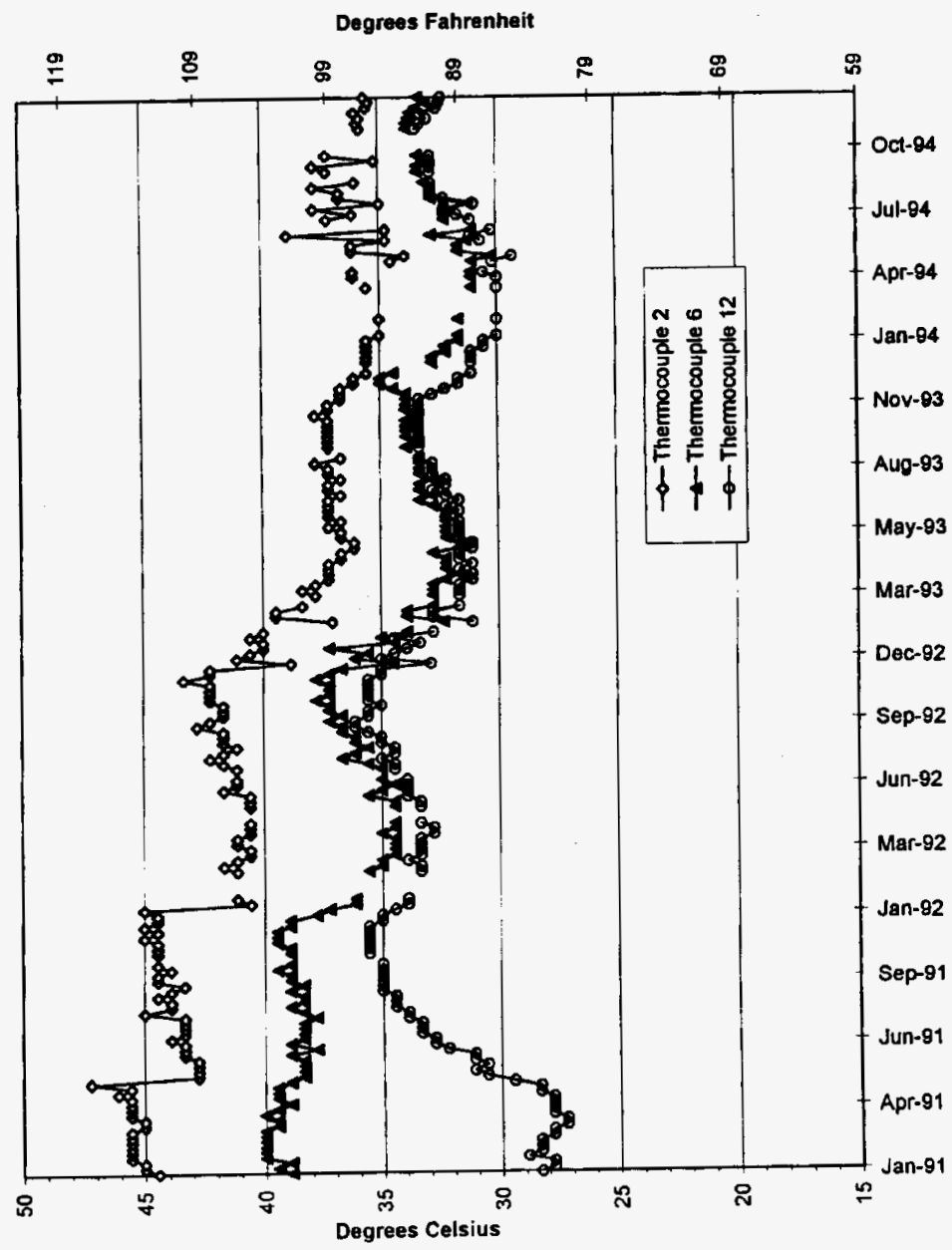


and $93^{\circ} \mathrm{F}$ ). Data from the Multifunctional Instrument Tree can help establish the boundary between convective and nonconvective layers. Figure 2-7 shows the axial temperature profile along with the core segment location (Wilkins 1995b).

\subsubsection{Gas Monitoring}

Hydrogen gas is measured in the exhaust gas using a standard hydrogen monitoring system. The system consists of two Whittaker cells. One cell has a range of 0 to 1 percent; the other has a range of 0 to 10 percent. For a description of the standard hydrogen monitoring system and gas monitoring results, see Wilkins (1995a).

Grab samples indicate that the baseline hydrogen concentration is below $100 \mathrm{ppm}$ (0.01 percent). Gas release events have occurred approximately every two to four months since December 1994. The highest hydrogen concentration measured during these events was 0.294 volume percent on May 2, 1995, which is equivalent to 7.4 percent of the LFL for hydrogen.

Nitrous oxide, ammonia, and methane have been measured in addition to hydrogen. Nitrous oxide concentrations ranged from 4 to $39 \mathrm{ppm}$ in grab samples taken in August and September of 1994. Two grab samples taken during the March 2, 1995 gas release had $\mathrm{N}_{2} \mathrm{O}$ results of 630 and $900 \mathrm{ppm}$. Grab samples taken in August 1995 detected methane at 12 and $15 \mathrm{ppm}$.

Ammonia was measured in the vent header from mid-December to mid-January (1994 to 1995). Concentrations ranged from 40 to $180 \mathrm{ppm}$. Ammonia is also measured at the SY Tank Farm stack exhaust to detect any ammonia from the three SY tanks. The estimated contribution of ammonia from tank 241-SY-103 at the time of the peak concentration at the SY Tank Farm stack during the May 2, 1995, gas release from tank 241-SY-103 was $486 \mathrm{ppm}$, which is equivalent to about 0.3 percent of the LFL for ammonia.

\subsubsection{In-Tank Photographs}

The interior of tank 241-SY-103 was most recently photographed in October 1985. Approximately $492 \mathrm{~kL}$ (130 kgal) of waste was added to the tank since the photographs were taken; therefore, the photographs no longer reflect current conditions in the tank and are not included in this report. A TV camera, that permits viewing of the waste surface, is installed in the tank headspace. 
Figure 2-7. Tank 241-SY-103 MIT 17B Validation Probe Results.

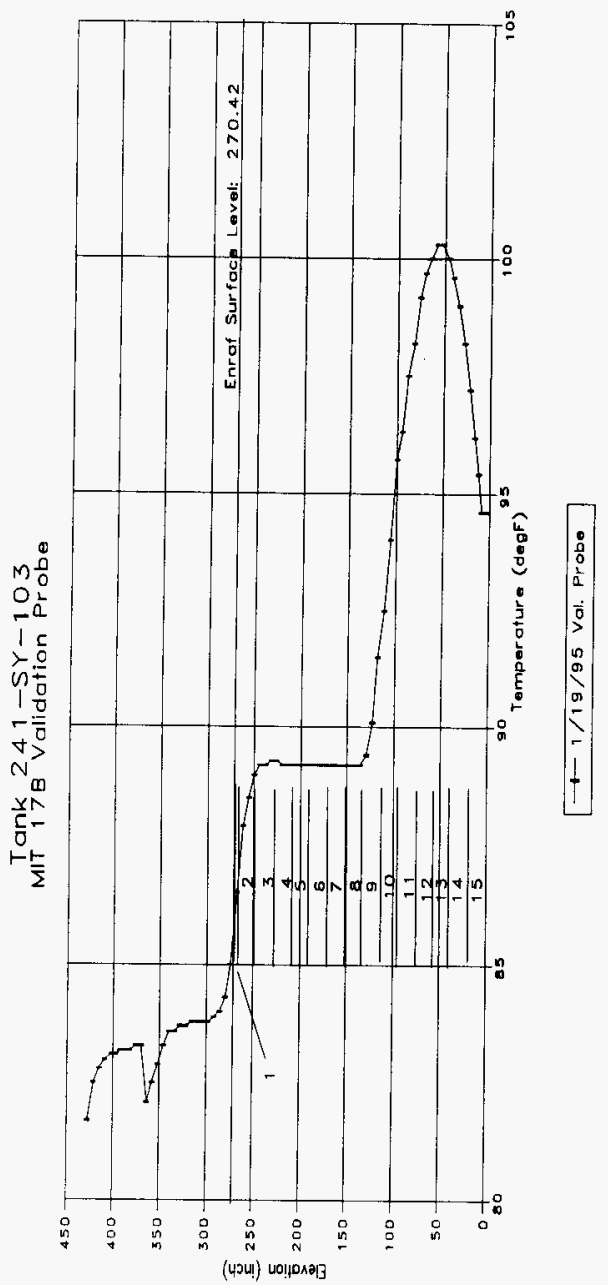




\subsection{TANK SAMPLING OVERVIEW}

This section describes three sampling events associated with tank 241-SY-103. A push-mode core was acquired in August and September of 1994 in support of the Tank Safety Screening Data Quality Objective (DQO) (Babad and Redus 1994), the Flammable Gas Tank Safety Program: Data Requirements for Core Sample Analysis Developed Through the Data Quality Objective Process (McDuffie and Johnson 1994), and Tank 241-SY-103 Tank

Characterization Plan (Schreiber 1994b and 1995). In June 1994, auger sampling and analysis of the tank's crust material were completed to ensure that further core sampling could be carried out in a safe manner. In 1986, core samples were taken from tank 241-SY-103 in support of retrieval, transport, and pretreatment characterization activities.

Results for the 1994 push-mode core sampling event may be found in 45-Day Safery Screen Results for Tank 241-SY-103, Core 62 and 216-Day Final Report for Tank 241-SY-103 Push Mode, Core 62 reports (Rice 1994 and 1995). The results for the auger sampling event are given in the 45-Day Deliverable for Tank 241-SY-103 (Kocher 1994) and the 136-Day Deliverable for Tank 241-SY-103 Auger Samples, Risers 7A, 14B, and 22A (Bell 1994). The results for the 1986 sampling event are reported in Tank 103-SY Dissolution Study - Results of Physical Measurements (Prignano 1988a), Tank 103-SY Dissolution Study - Results of Chemical Analyses (Prignano 1988b), and Characterization of Waste from Double-Shell Tank 103-SY, A Letter Report for Rockwell Hanford Operations (Fow et al. 1986). Pre-May 1989 data may not be acceptable for waste decisions because adequate quality control information for the data is not available to assess data quality and enable confident decisions.

\subsection{DESCRIPTION OF THE 1994 CORE SAMPLING EVENT}

During August and September of 1994, one push-mode core was obtained from riser 14A of tank 241-SY-103. The core consisted of 15 segments and was numbered core 62 . A solution of 0.3 molar $(M)$ lithium bromide was used for the hydrostatic head fluid (HHF). Originally, a second core sample was planned, but it was not acquired because of safety concerns related to sample pressurization of the last core segment. Because the second core has not been acquired, the duplicate sampler requirements of the tank safety screening DQO have not been met for this tank (Babad and Redus 1994).

Table 3-1 summarizes the sampling information for this event. The third column lists the approximate elevation of the top of each segment as measured from the bottom of the tank, using the solids level measurement of $6.86 \mathrm{~m}(22.5 \mathrm{ft})$ taken by manual tape in July 1994 (Schreiber 1994b). It should be noted that the first segment was only to a depth of $10 \mathrm{~cm}$ (4 in.). The depth information is given as a guide and is not precise. Table 3-1 also 
Table 3-1. Tank 241-SY-103 Core 62 Sampling Information ${ }^{1}$.

\begin{tabular}{|c|c|c|c|c|c|c|}
\hline Segineing & 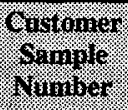 & 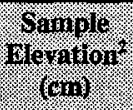 & \%). & 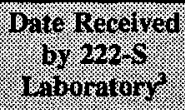 & 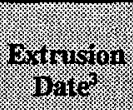 & 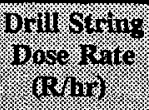 \\
\hline \multicolumn{7}{|c|}{ pher $14 \%$} \\
\hline 1 & $94-005$ & 714 & $8 / 19 / 94$ & $8 / 22 / 94$ & $8 / 24 / 94$ & 2 \\
\hline 2 & $94-006$ & 666 & $8 / 19 / 94$ & $8 / 22 / 94$ & $8 / 24 / 94$ & 2.2 \\
\hline 3 & $94-007$ & 617 & $8 / 23 / 94$ & $8 / 25 / 94$ & $8 / 26 / 94$ & 2.2 \\
\hline 4 & $94-008$ & 569 & $8 / 23 / 94$ & $8 / 25 / 94$ & $8 / 26 / 94$ & 2 \\
\hline 5 & $94-009$ & 521 & $9 / 8 / 94$ & $9 / 9 / 94$ & $9 / 12 / 94$ & 2.2 \\
\hline 6 & $94-010$ & 473 & $9 / 13 / 94$ & $9 / 15 / 94$ & $9 / 16 / 94$ & 2.5 \\
\hline 7 & 94-011 & 425 & $9 / 13 / 94$ & $9 / 15 / 94$ & $9 / 16 / 94$ & 2 \\
\hline 8 & 94-012 & 376 & $9 / 13 / 94$ & $9 / 15 / 94$ & $9 / 19 / 94$ & 2 \\
\hline 9 & $94-013$ & 328 & $9 / 13 / 94$ & $9 / 15 / 94$ & $9 / 19 / 94$ & 1.9 \\
\hline 10 & $94-014$ & 280 & $9 / 13 / 94$ & $9 / 15 / 94$ & $9 / 20 / 94$ & 1.7 \\
\hline 11 & $94-015$ & 232 & $9 / 16 / 94$ & $9 / 19 / 94$ & $9 / 21 / 94$ & 1.9 \\
\hline 12 & $94-016$ & 183 & $9 / 16 / 94$ & $9 / 19 / 94$ & $9 / 22 / 94$ & 1.7 \\
\hline 13 & $94-017$ & 135 & $9 / 16 / 94$ & $9 / 19 / 94$ & $9 / 23 / 94$ & 1.8 \\
\hline 14 & $94-018$ & 87 & $9 / 19 / 94$ & $9 / 21 / 94$ & $9 / 23 / 94$ & 1.8 \\
\hline 15 & $94-019$ & 39 & $9 / 19 / 94$ & $9 / 21 / 94$ & $9 / 26 / 94$ & 1.5 \\
\hline $\begin{array}{l}\text { field } \\
\text { blank }\end{array}$ & $\mathrm{n} / \mathrm{a}$ & $\mathrm{n} / \mathrm{a}$ & $\mathrm{n} / \mathrm{a}$ & $\mathrm{n} / \mathrm{a}$ & $\mathrm{n} / \mathrm{a}$ & $\mathrm{n} / \mathrm{a}$ \\
\hline HHF & & $\mathrm{n} / \mathrm{a}$ & & & $\mathrm{n} / \mathrm{a}$ & $\mathrm{n} / \mathrm{a}$ \\
\hline
\end{tabular}

Notes:

$\mathbf{n} / \mathbf{a}=$ not available

${ }^{1}$ Rice (1994)

${ }^{2}$ As measured from the bottom of the tank to the top of the core segment; values are approximate.

${ }^{3}$ Dates are listed in the $\mathrm{mm} / \mathrm{dd} / \mathrm{yy}$ format.

The 222-S Laboratory has no record of receipt or analysis of a field blank. 
provides the sample date, the date the sample was received by the laboratory, the date the sample was extruded, and the drill string dose rate as reported in chain-of-custody documentation.

The 241-SY-103 tank characterization plan for the push-mode sampling and analysis required the collection of an HHF sample and a field blank of deionized water (Schreiber 1995). The HHF sample, which was taken from the HHF batch used during push-mode sampling, was used to determine the original lithium and bromide concentrations in the HHF. These concentrations may then be used to subsequently correct for HHF water contamination of the samples should the lithium and bromide analyses of the core samples reveal that such contamination occurred. The HHF sample was collected and sent to the 222-S Laboratory as directed by the tank characterization plan. However, Rice (1995) contains no record of the receipt or analysis of a deionized water field blank; therefore, the field blank requirement of Schreiber (1995) was not satisfied.

\subsubsection{Core Sample Handling}

The samples were extruded and subsampled in the 222-S Laboratory hot cell. Table 3-2 lists the segment number, the percent of sample recovered, the liquid volume of the segment, the solid mass of the segment, and a description of the sample. A flow chart of the sample breakdown is described in the sample and analysis plan (Schreiber 1994a).

The only problems noted were during the extrusion of segments 3 and 15 . When the valve for segment 3 was first opened, no liquid sample appeared. Apparently a solid plug had formed. Once the extrusion began, this solid plug was pushed onto the tray followed rapidly by the drainable liquid. Some liquid was lost out the back of the sample tray, and much of the solid was carried into the drainable liquid jar with the liquid. When segment 15 of core 62 was extruded in the 222-S Laboratory hot cell, internal pressure in the sampler caused approximately $20 \mathrm{~mL}$ of sample material to be sprayed on the wall of the hot cell. This pressurization was not anticipated. No injuries or imminent safety hazards resulted from the release (Rice 1994).

After extrusion, each segment of core 62 was divided into two subsamples: segments 1 through 9 and segment 15 were divided into drainable liquids and solids, segments 10 through 14 did not contain any drainable liquid and were divided into upper and lower segment halves. The drainable liquid subsamples were analyzed by DSC and thermogravimetric analysis (TGA); DSC, TGA, and total alpha activity determinations were performed on the solids from segments 1 through 9 and segment 15 and the upper and lower segment halves from segments 10 through 14 . Each subsample underwent safety screening analysis according to Schreiber (1994b). In addition, an HHF sample used during sampling was analyzed for lithium and bromide. 
Table 3-2. Tank 241-SY-103 Core 62 Subsampling Information'. (2 sheets)

\begin{tabular}{|c|c|c|c|c|}
\hline Segnient & moner & Woinglo & oflo & (S) \\
\hline 1 & 91 & 262 & 22 & $\begin{array}{l}\text { The liquid was turbid and medium brown in color. } \\
\text { The solids resembled dirty ice crystals, much like } \\
\text { "snow cone" ice. }\end{array}$ \\
\hline 2 & 91 & 272 & 9.6 & $\begin{array}{l}\text { The liquid was turbid and medium brown in color. } \\
\text { The solids resembled dirty ice crystals, much like } \\
\text { "snow cone" ice. }\end{array}$ \\
\hline 3 & 91 & $\begin{array}{l}-262 \\
( \pm 10)\end{array}$ & 5.8 & $\begin{array}{l}\text { When the valve was first opened, no liquid sample } \\
\text { appeared. When the extrusion began, the solid } \\
\text { material was pushed onto the tray followed rapidly } \\
\text { by the drainable liquid. Some liquid was lost out } \\
\text { the back of the sample tray and much of the solid } \\
\text { was carried into the drainable liquid jar with the } \\
\text { liquid. The liquid was turbid and medium brown } \\
\text { in color. The solids resembled dirty ice crystals, } \\
\text { much like "snow cone" ice. }\end{array}$ \\
\hline 4 & 100 & 295 & 33 & $\begin{array}{l}\text { The liquid was turbid and medium brown in color. } \\
\text { The solids resembled dirty ice crystals, much like } \\
\text { "snow cone" ice. }\end{array}$ \\
\hline 5 & 95 & 270 & 36 & $\begin{array}{l}\text { The liquid was turbid and medium brown in color. } \\
\text { The solids resembled dirty ice crystals, much like } \\
\text { "snow cone" ice. }\end{array}$ \\
\hline 6 & 92 & 260 & 34 & $\begin{array}{l}\text { The liquid was turbid and medium brown in color. } \\
\text { The solids resembled dirty ice crystals, much like } \\
\text { "snow cone" ice. }\end{array}$ \\
\hline 7 & 88 & 262 & 22 & $\begin{array}{l}\text { The liquid was turbid and medium brown in color. } \\
\text { The solids resembled dirty ice crystals, much like } \\
\text { "snow cone" ice. }\end{array}$ \\
\hline 8 & 98 & 295 & 22 & $\begin{array}{l}\text { The liquid was turbid and medium brown in color. } \\
\text { The solids resembled dirty ice crystals, much like } \\
\text { "snow cone" ice. }\end{array}$ \\
\hline 9 & 92 & 35 & 369 & $\begin{array}{l}\text { The drainable liquid was dark brown and opaque. } \\
\text { The solid sample did not retain its shape following } \\
\text { extrusion but spread slowly across the sample tray. } \\
\text { The dark brown solids appeared homogeneous, } \\
\text { with the consistency of thin, wet mud. }\end{array}$ \\
\hline
\end{tabular}


Table 3-2. Tank 241-SY-103 Core 62 Subsampling Information'. (2 sheets)

\begin{tabular}{|c|c|c|c|c|}
\hline $\begin{array}{l}\text { Seginirat } \\
\text { Nunbor }\end{array}$ & 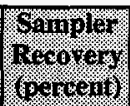 & 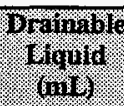 & Soling & Sample Descript ion \\
\hline 10 & 85 & 0 & 381 & $\begin{array}{l}\text { This segment contained no drainable liquid. The } \\
\text { lower half segment was dark brown and retained } \\
\text { the shape of the sampler after extrusion. The } \\
\text { upper half was more wet and did not retain its } \\
\text { shape, with the upper quarter being similar in } \\
\text { appearance to segment } 9 \text {. }\end{array}$ \\
\hline 11 & 95 & 0 & 431 & $\begin{array}{l}\text { This segment contained no drainable liquid. The } \\
\text { solid material was slightly different in color from } \\
\text { segment } 10 \text {, having a gray vs. a red cast to the } \\
\text { otherwise homogeneous brown color. This change } \\
\text { occurred gradually, without a layering effect. The } \\
\text { sample retained its shape following extrusion and } \\
\text { was slightly pitted at the surface. }\end{array}$ \\
\hline 12 & 95 & 0 & 382 & $\begin{array}{l}\text { This segment contained no drainable liquid. The } \\
\text { solid material was gray brown in color, soft and } \\
\text { damp in texture, much like segment } 11 \text {. The } \\
\text { sample retained its shape following extrusion and } \\
\text { was slightly pitted at the surface. }\end{array}$ \\
\hline 13 & 95 & 0 & 429 & $\begin{array}{l}\text { This segment contained no drainable liquid. The } \\
\text { solid material was gray brown in color, soft and } \\
\text { damp in texture, much like segments } 11 \text { and } 12 \text {. } \\
\text { The sample retained its shape following extrusion } \\
\text { and was slightly pitted at the surface. }\end{array}$ \\
\hline 14 & 80 & 0 & 352 & $\begin{array}{l}\text { This segment contained no drainable liquid. } \\
\text { About } 25 \mathrm{~cm}(10 \mathrm{in} \text {.) of solid were extruded, } \\
\text { followed by a } 10-\mathrm{cm} \text { ( } 4 \text {-in.) air gap, then } 10 \text { to } \\
13 \mathrm{~cm} \text { ( } 4 \text { to } 5 \text { in.) of solids. The solid material } \\
\text { was gray brown in color, soft and damp in } \\
\text { texture, and was slightly pitted at the surface. }\end{array}$ \\
\hline 15 & 52 & 125 & $n / a$ & $\begin{array}{l}\text { This segment was composed primarily of drainable } \\
\text { liquid. When the sampler valve was opened, an } \\
\text { estimated } 20 \mathrm{~mL} \text { of liquid sprayed onto the hot } \\
\text { cell wall. The amount of solids was difficult to } \\
\text { determine due to the runny texture. }\end{array}$ \\
\hline
\end{tabular}

Note:

$\mathrm{n} / \mathrm{a}=$ not available

'Rice (1994) 
After the safety screening subsamples had been removed, the segments were visually evaluated for facies and strata. The drainable liquid was separated into the following subsamples: segments 1, 8, 9 and 15 (individual samples); and segments 2 through 7 (subsamples combined into a drainable liquid composite). The solids in segment 1, which were left behind after the liquid drained away, were identified as stratum 1 because they may contain crust material. Solids from segments 4 through 8 were combined into a stratum $B$ composite (segments 2 and 3 contained insufficient solids to include in the composite). Segment 9 represented the liquid-solid interface, and the solids in it were treated as their own stratum (stratum C). Subsamples in segments 10 through 14 were collected into a composite labeled stratum D. Apparent sampling problems in segment 15 caused it to be analyzed separately.

Table 3-3 summarizes the subsampling and compositing of the extruded core segments. The table also includes the laboratory sample numbers and the analyses performed on each sample.

\subsubsection{Core Sample Analysis}

This section provides information about the analysis of the 1994 core. Table 3-3 summarizes the core segment subsampling and compositing scheme and the analyses performed on each subsample and composite. Table 3-4 lists the sample preparation and analytical procedures used to perform the analyses.

Safety screening analyses were performed on the subsamples of core 62 according to the Tank Safety Screening Data Quality Objective (Babad and Redus 1994), the Flammable Gas Tank Safety Program: Data Requirements for Core Sample Analysis Developed Through the Data Quality Objective Process (McDuffie and Johnson 1994), and the tank 241-SY-103 TCP (Schreiber 1994b and 1995). The safety screening DQO required that the safety screening analyses be performed on half segments. However, the flammable gas DQO required that analyses be performed on composite samples made from discrete core strata. To meet both requirements, the tank characterization plan instructed that sample aliquots for the safety screening analyses be taken without dividing the segment into half segments or disturbing the stratification of the segment. Aliquots were to be removed from both halves of the segment without homogenization, as if the segment had been divided into half segments.

The safety screening aliquots from core 62 were analyzed for energetics by DSC, percent water by TGA, and total alpha activity. The results from the safety screening analyses are reported in the 45-Day Safety Screen Results for Tank 241-SY-103, Core 62 (Rice 1994) and the 216-Day Safety Screen Results for Tank 241-SY-103 Push Mode, Core 62 (Rice 1995), and are included in Appendix A. For results from these reports, see Section 4.0. 
Table 3-3. Tank 241-SY-103 Core 62 Summary of Subsamples and Analyses. (4 sheets)

\begin{tabular}{|c|c|c|c|}
\hline (6) & 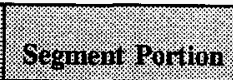 & 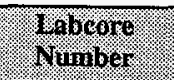 & W. \\
\hline (1) & S: & Riser y & \\
\hline \multirow[t]{2}{*}{1} & drainable liquid & $\begin{array}{l}\text { S94T000008 } \\
\text { S94T000009 } \\
\text { S95T000281 } \\
\text { S95T000323 }\end{array}$ & $\begin{array}{l}\text { DSC, TGA } \\
\text { ICP } \\
\text { DSC, TGA, pH, TOC } \\
\text { ICP }\end{array}$ \\
\hline & $\begin{array}{l}\text { solids } \\
\text { (Stratum A) }\end{array}$ & $\begin{array}{l}\text { S94T000004 } \\
\text { S94T000005 } \\
\text { S94T000006 } \\
\text { S94T000265 } \\
\text { S94T000266 } \\
\text { S94T000267 } \\
\text { S94T000268 }\end{array}$ & $\begin{array}{l}\text { DSC, TGA } \\
\text { AT, ICP, uranium, radionuclides } \\
\text { density } \\
\text { pH, TIC, TOC } \\
\text { ICP } \\
\text { IC, hydroxide, chromium(VI), tritium } \\
\text { GEA, radionuclides }\end{array}$ \\
\hline \multirow[t]{2}{*}{2} & drainable liquid & $\begin{array}{l}\text { S94T000015 } \\
\text { S94T000016 }\end{array}$ & $\begin{array}{l}\text { DSC, TGA } \\
\text { ICP }\end{array}$ \\
\hline & solids & $\begin{array}{l}\text { S94T000011 } \\
\text { S94T000012 }\end{array}$ & $\begin{array}{l}\text { DSC, TGA } \\
\text { AT, ICP }\end{array}$ \\
\hline \multirow[t]{2}{*}{3} & drainable liquid & $\begin{array}{l}\text { S94T000025 } \\
\text { S94T000026 }\end{array}$ & $\begin{array}{l}\text { DSC, TGA } \\
\text { ICP }\end{array}$ \\
\hline & solids & $\begin{array}{l}\text { S94T000020 } \\
\text { S94T000021 }\end{array}$ & $\begin{array}{l}\text { DSC, TGA } \\
\text { AT, ICP }\end{array}$ \\
\hline \multirow[t]{2}{*}{4} & drainable liquid & $\begin{array}{l}\text { S94T000032 } \\
\text { S94T000033 }\end{array}$ & $\begin{array}{l}\text { DSC, TGA } \\
\text { ICP }\end{array}$ \\
\hline & solids & $\begin{array}{l}\text { S94T000028 } \\
\text { S94T000029 }\end{array}$ & $\begin{array}{l}\text { DSC, TGA, TOC } \\
\text { AT, ICP }\end{array}$ \\
\hline \multirow[t]{2}{*}{5} & drainable liquid & $\begin{array}{l}\text { S94T000040 } \\
\text { S94T000041 }\end{array}$ & $\begin{array}{l}\text { DSC, TGA } \\
\text { ICP }\end{array}$ \\
\hline & solids & $\begin{array}{l}\text { S94T000036 } \\
\text { S94T000037 }\end{array}$ & $\begin{array}{l}\text { DSC, TGA } \\
\text { AT, ICP }\end{array}$ \\
\hline \multirow[t]{2}{*}{6} & drainable liquid & $\begin{array}{l}\text { \$94T000105 } \\
\text { S94T000109 }\end{array}$ & $\begin{array}{l}\text { DSC, TGA } \\
\text { ICP }\end{array}$ \\
\hline & solids & $\begin{array}{l}\text { S94T000055 } \\
\text { S94T000064 }\end{array}$ & $\begin{array}{l}\text { DSC, TGA } \\
\text { AT, ICP }\end{array}$ \\
\hline \multirow[t]{2}{*}{7} & drainable liquid & $\begin{array}{l}\text { S94T000106 } \\
\text { S94T000110 }\end{array}$ & $\begin{array}{l}\text { DSC, TGA } \\
\text { ICP }\end{array}$ \\
\hline & solids & $\begin{array}{l}\text { S94T000056 } \\
\text { S94T000065 }\end{array}$ & $\begin{array}{l}\text { DSC, TGA } \\
\text { AT, ICP }\end{array}$ \\
\hline
\end{tabular}


Table 3-3. Tank 241-SY-103 Core 62 Summary of Subsamples and Analyses. (4 sheets)

\begin{tabular}{|c|c|c|c|}
\hline Sognimit. & 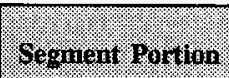 & Subcors & 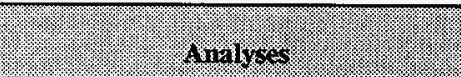 \\
\hline \multirow[t]{2}{*}{8} & drainable liquid & $\begin{array}{l}\text { S94T000082 } \\
\text { S94T000107 } \\
\text { S94T000111 } \\
\text { S95T000283 } \\
\text { S95T000325 } \\
\text { S95T000329 } \\
\text { S95T000333 }\end{array}$ & $\begin{array}{l}\text { density } \\
\text { DSC, TGA } \\
\text { ICP } \\
\text { DSC, pH, TGA, TOC } \\
\text { ICP } \\
\text { AT, total beta, uranium, radionuclides } \\
\text { IC, hydroxide, chromium(VI), }{ }^{129} \mathrm{I}\end{array}$ \\
\hline & solids & $\begin{array}{l}\text { S94T000057 } \\
\text { S94T000066 }\end{array}$ & $\begin{array}{l}\text { DSC, TGA } \\
\text { AT, ICP }\end{array}$ \\
\hline \multirow[t]{2}{*}{9} & drainable liquid & $\begin{array}{l}\text { S94T000108 } \\
\text { S94T000112 }\end{array}$ & $\begin{array}{l}\text { DSC, TGA } \\
\text { ICP }\end{array}$ \\
\hline & $\begin{array}{l}\text { solids } \\
\text { (Stratum C) }\end{array}$ & $\begin{array}{l}\text { S94T000058 } \\
\text { S94T000067 } \\
\text { S94T000077 } \\
\text { S94T000274 } \\
\text { S94T000277 } \\
\text { S94T000280 } \\
\text { S94T000283 } \\
\text { S95T000295 }\end{array}$ & $\begin{array}{l}\text { DSC, TGA } \\
\text { AT, ICP, total beta, radionuclides, } \\
\text { uranium } \\
\text { density } \\
\text { pH, TIC, TOC } \\
\text { ICP } \\
\text { IC, hydroxide, chromium(VI), tritium } \\
\text { GEA, radionuclides } \\
{ }^{99} \mathrm{Tc}\end{array}$ \\
\hline \multirow[t]{2}{*}{10} & upper $1 / 2$ aliquot & $\begin{array}{l}\text { S94T000063 } \\
\text { S94T000069 }\end{array}$ & $\begin{array}{l}\text { DSC, TGA } \\
\text { AT, ICP }\end{array}$ \\
\hline & lower $1 / 2$ aliquot & $\begin{array}{l}\text { S94T000070 } \\
\text { S94T000068 }\end{array}$ & $\begin{array}{l}\text { DSC, TGA } \\
\text { AT, ICP }\end{array}$ \\
\hline \multirow[t]{2}{*}{11} & upper $1 / 2$ aliquot & $\begin{array}{l}\text { S94T000072 } \\
\text { S94T000119 }\end{array}$ & $\begin{array}{l}\text { DSC, TGA } \\
\text { AT, ICP }\end{array}$ \\
\hline & lower $1 / 2$ aliquot & $\begin{array}{l}\text { S94T000071 } \\
\text { S94T000094 }\end{array}$ & $\begin{array}{l}\text { DSC, TGA } \\
\text { AT, ICP }\end{array}$ \\
\hline \multirow[t]{2}{*}{12} & upper $1 / 2$ aliquot & $\begin{array}{l}\text { S94T000085 } \\
\text { S94T000120 }\end{array}$ & $\begin{array}{l}\text { DSC, TGA } \\
\text { AT, ICP }\end{array}$ \\
\hline & lower $1 / 2$ aliquot & $\begin{array}{l}\text { S94T000090 } \\
\text { S94T000095 }\end{array}$ & $\begin{array}{l}\text { DSC, TGA } \\
\mathrm{AT}, \mathrm{ICP}\end{array}$ \\
\hline
\end{tabular}


Table 3-3. Tank 241-SY-103 Core 62 Summary of Subsamples and Analyses. (4 sheets)

\begin{tabular}{|c|c|c|c|}
\hline Stequitit: & Segrilent Pontion & Yumber & (2) (2) \\
\hline \multirow[t]{3}{*}{13} & liner liquid & $\begin{array}{l}\text { S95T000284 } \\
\text { S95T000326 } \\
\text { S95T000330 } \\
\text { S95T000334 }\end{array}$ & $\begin{array}{l}\text { DSC, pH, TGA, TOC } \\
\text { ICP } \\
\text { AT, total beta, uranium, radionuclides } \\
\text { IC, hydroxide, chromium(VI), }{ }^{129} \mathrm{I}\end{array}$ \\
\hline & upper $1 / 2$ aliquot & $\begin{array}{l}\text { S94T000088 } \\
\text { S94T000121 }\end{array}$ & $\begin{array}{l}\text { DSC, TGA } \\
\text { AT, ICP }\end{array}$ \\
\hline & lower $1 / 2$ aliquot & $\begin{array}{l}\text { S94T000091 } \\
\text { S94T000096 }\end{array}$ & $\begin{array}{l}\text { DSC, TGA, cyanide, TOC } \\
\text { AT, ICP }\end{array}$ \\
\hline \multirow[t]{2}{*}{14} & upper $1 / 2$ aliquot & $\begin{array}{l}\text { S94T000089 } \\
\text { S94T000122 }\end{array}$ & $\begin{array}{l}\text { DSC, TGA } \\
\text { AT, ICP }\end{array}$ \\
\hline & lower $1 / 2$ aliquot & $\begin{array}{l}\text { S94T000092 } \\
\text { S94T000097 }\end{array}$ & $\begin{array}{l}\text { DSC, TGA, cyanide, TOC } \\
\text { AT, ICP }\end{array}$ \\
\hline \multirow[t]{3}{*}{15} & liner liquid & $\begin{array}{l}\text { S95T000262 } \\
\text { S95T000285 } \\
\text { S95T000327 } \\
\text { S95T000331 } \\
\text { S95T000335 }\end{array}$ & $\begin{array}{l}\text { density } \\
\text { DSC, pH, TGA, TOC } \\
\text { ICP } \\
\text { AT, total beta, uranium, radionuclides } \\
\text { IC, hydroxide, chromium(VI), }{ }^{129} \mathrm{I}\end{array}$ \\
\hline & drainable liquid & $\begin{array}{l}\text { S94T000104 } \\
\text { S94T000113 }\end{array}$ & $\begin{array}{l}\text { DSC, TGA } \\
\text { ICP }\end{array}$ \\
\hline & solids & $\begin{array}{l}\text { S94T000093 } \\
\text { S94T000098 }\end{array}$ & $\begin{array}{l}\text { DSC, TGA } \\
\text { AT, ICP }\end{array}$ \\
\hline Stratum A & $\begin{array}{l}\text { see segment } 1 \text {, } \\
\text { solids }\end{array}$ & & \\
\hline Stratum B & $\begin{array}{l}\text { composite of } \\
\text { segments } 4 \text { to } 8 \\
\text { solids }\end{array}$ & $\begin{array}{l}\text { S94T000273 } \\
\text { S94T000276 } \\
\text { S94T000279 } \\
\text { S94T000282 } \\
\text { S94T000299 } \\
\text { S95T000739 }\end{array}$ & $\begin{array}{l}\text { DSC, TGA, pH, TIC, TOC } \\
\text { ICP } \\
\text { IC, hydroxide, chromium(VI), tritium } \\
\text { GEA, radionuclides } \\
\text { ICP, AT, total beta, GEA, uranium, } \\
\text { radionuclides } \\
\text { density }\end{array}$ \\
\hline Stratum C & $\begin{array}{l}\text { see segment } 9 \text {, } \\
\text { solids }\end{array}$ & & \\
\hline
\end{tabular}


Table 3-3. Tank 241-SY-103 Core 62 Summary of Subsamples and Analyses. (4 sheets)

\begin{tabular}{|c|c|c|c|}
\hline Stginenit & Seginent Roritin & $\begin{array}{l}\text { Thlocoro } \\
\text { Vumber }\end{array}$ & 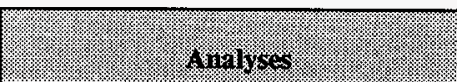 \\
\hline Stratum D & $\begin{array}{l}\text { composite of } \\
\text { segments } 10 \text { to } 14 \\
\text { solids }\end{array}$ & $\begin{array}{l}\text { S94T000271 } \\
\text { S94T000275 } \\
\text { S94T000278 } \\
\text { S94T000281 } \\
\text { S94T000284 } \\
\text { S94T000300 } \\
\\
\text { S95T000291 } \\
\text { S95T000296 }\end{array}$ & $\begin{array}{l}\text { density } \\
\text { DSC, TGA, pH, TIC, TOC } \\
\text { ICP } \\
\text { IC, hydroxide, chromium(VI), tritium } \\
\text { GEA, radionuclides } \\
\text { ICP, AT, total beta, GEA, uranium, } \\
\text { radionuclides } \\
{ }^{129} \mathrm{I} \\
{ }^{99} \mathrm{Tc}\end{array}$ \\
\hline Field Blank ${ }^{1}$ & $\mathrm{n} / \mathrm{a}$ & $n / a$ & $n / a$ \\
\hline HHF & $\mathrm{n} / \mathrm{a}$ & S94T000127 & ICP, IC \\
\hline
\end{tabular}

Notes:

$\mathrm{n} / \mathbf{a}=$ not applicable

${ }^{1}$ The 222-S Laboratory has no record of the receipt of a field blank. 
Table 3-4. Core 62 Analytical Procedures. (2 sheets)

\begin{tabular}{|c|c|c|c|}
\hline $101 \% \mathrm{sir}$ & Wholmon & . & 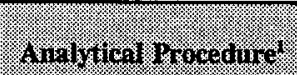 \\
\hline DSC: energetics & Mettler ${ }^{\mathrm{TM}}$ & $\mathrm{n} / \mathrm{a}$ & LA-514-113, B-1 \\
\hline $\begin{array}{l}\text { TGA: percent } \\
\text { water }\end{array}$ & $\begin{array}{l}\text { Mettler }^{\mathrm{TM}} \\
\text { Perkin-Elmer }\end{array}$ & $\mathrm{n} / \mathrm{a}$ & $\begin{array}{l}\text { LA-560-112, A-2 } \\
\text { LA-514-114, B-0 }\end{array}$ \\
\hline $\begin{array}{l}\text { AT/total beta: } \\
\text { total alpha/beta } \\
\text { activity }\end{array}$ & proportional counter & $\begin{array}{l}\text { LA-505-158, A-4 } \\
\text { LA-549-141, C-1 }\end{array}$ & LA-508-101, D-2 \\
\hline Density: Solids & $\mathrm{n} / \mathrm{a}$ & $\mathrm{n} / \mathrm{a}$ & LO-160-103, A-7 \\
\hline Density: Liquids & $\mathrm{n} / \mathrm{a}$ & $\mathrm{n} / \mathrm{a}$ & LA-560-101 \\
\hline $\begin{array}{l}\text { ICP: } \\
\text { Lithium/metals }\end{array}$ & $\begin{array}{l}\text { inductively coupled } \\
\text { plasma spectrometer }\end{array}$ & $\begin{array}{l}\text { LA-505-158, A-4 } \\
\text { LA-505-159, B-2 } \\
\text { LA-549-141, C-1 }\end{array}$ & $\begin{array}{l}\text { LA-505-151, D-1 } \\
\text { LA-505-161, A-1 }\end{array}$ \\
\hline $\begin{array}{l}\text { IC: } \\
\text { Bromide/anions }\end{array}$ & ion chromatograph & LA-504-101, C-0 & LA-533-105, C-2 \\
\hline $\begin{array}{l}\text { GEA: } \\
\text { Radionuclides }\end{array}$ & $\begin{array}{l}\text { gamma detector } \\
\text { spectrometer }\end{array}$ & $\begin{array}{l}\text { LA-505-158, A-4 } \\
\text { LA-549-141, C-1 }\end{array}$ & LA-548-121, D-1 \\
\hline${ }^{129}$ Iodine & $\begin{array}{l}\text { solvent } \\
\text { extraction/GEA }\end{array}$ & $\mathrm{n} / \mathrm{a}$ & LA-378-103, B-3 \& B-4 \\
\hline${ }^{90}$ Strontium & $\begin{array}{l}\text { precipitation/beta } \\
\text { count }\end{array}$ & $\begin{array}{l}\text { LA-505-158, A-4 } \\
\text { LA-549-141, C-1 }\end{array}$ & LA-220-101, D-1 \\
\hline${ }^{99}$ Technetium & $\begin{array}{l}\text { solvent } \\
\text { extraction/liquid } \\
\text { scintillation count }\end{array}$ & $\begin{array}{l}\text { LA-505-158, A-4 } \\
\text { LA-549-141, C-1 }\end{array}$ & LA-438-101, D-2 \\
\hline${ }^{237}$ Neptunium & $\begin{array}{l}\text { solvent } \\
\text { extraction/alpha count }\end{array}$ & $\begin{array}{l}\text { LA-505-158, A-4 } \\
\text { LA-549-141, C-1 }\end{array}$ & LA-933-141, H-0 \& H-1 \\
\hline${ }^{241} \mathrm{Am},{ }^{243 / 244} \mathrm{Cm}$ & $\begin{array}{l}\text { ion exchange/alpha } \\
\text { energy analysis }\end{array}$ & $\begin{array}{l}\text { LA-505-158, A-4 } \\
\text { LA-549-141, C-1 }\end{array}$ & LA-953-103, A-1 \& A-2 \\
\hline${ }^{238 / 239 / 240} \mathrm{Pu}$ & $\begin{array}{l}\text { ion exchange/alpha } \\
\text { energy analysis }\end{array}$ & $\begin{array}{l}\text { LA-505-158, A-4 } \\
\text { LA-549-141, C-1 }\end{array}$ & LA-503-156, D-1 \\
\hline Uranium & laser phosphorescence & $\begin{array}{l}\text { LA-505-158, A-4 } \\
\text { LA-549-141, C-1 }\end{array}$ & LA-925-009, A-0 \\
\hline Tritium & $\begin{array}{l}\text { microdistillation/liquid } \\
\text { scintillation count }\end{array}$ & LA-504-101, C-0 & LA-218-114, A-3 \& A-4 \\
\hline
\end{tabular}


Table 3-4. Core 62 Analytical Procedures. (2 sheets)

\begin{tabular}{|c|c|c|c|}
\hline Honges & 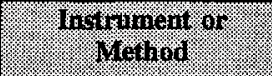 & 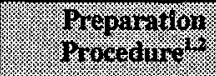 & 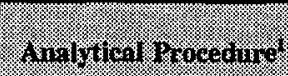 \\
\hline $\begin{array}{l}\text { TIC/TOC: total } \\
\text { inorganic/organic } \\
\text { carbon }\end{array}$ & $\begin{array}{l}\text { persulfate } \\
\text { oxidation/coulometric } \\
\text { detection }\end{array}$ & $\mathrm{n} / \mathrm{a}$ & $\begin{array}{l}\text { LA-342-100, A-0 } \\
\text { LA-344-105, B-3 }\end{array}$ \\
\hline Chromium(VI) & spectrophotometry & LA-504-101, C-0 & LA-265-101, A-2 \\
\hline Cyanide & $\begin{array}{l}\text { microdistillation/ } \\
\text { spectrophotometry }\end{array}$ & $\mathrm{n} / \mathrm{a}$ & LA-695-102, B-2 \\
\hline $\mathrm{pH}$ & glass electrode & $\mathrm{n} / \mathrm{a}$ & LA-212-103, B-3 \\
\hline Hydroxide ion & potentiometric titration & LA-504-101, C-0 & LA-211-102, B-1 \\
\hline
\end{tabular}

Notes:

$\mathrm{n} / \mathrm{a}=$ not applicable

Mettler ${ }^{\mathrm{TM}}$ is a registered trademark of Mettler Electronics, Anaheim, California.

Perkin-Elmer ${ }^{\mathrm{TM}}$ is a registered trademark of Perkins Research and Manufacturing Company, Inc., Canoga Park, California.

'Procedures refer to 222-S procedure numbers; procedure numbers ( $L x-\mathbf{x x x}-\mathbf{x x x})$ are followed by the revision code $(X-X)$.

${ }^{2}$ LA-504-101 = solid-sample water digest, LA-505-158 = liquid-sample acid dilution, LA-505-159 = solid-sample acid digest, LA-549-141 = solid-sample, alkali-metal fusion

The TGA and DSC analyses were done on 5- to 20-mg specimens of the waste material under a nitrogen atmosphere; however, DSC samples S95T000085 and S95T000105 were inadvertently run in air. Duplicate samples of S95T000085 and S95T000105 were run under nitrogen; the DSC behavior under nitrogen and air appeared to be identical. Therefore, the results obtained under air were considered acceptable and are included in this report. The total alpha activity specimens were prepared by fusing a solid aliquot ( 0.2 to 0.5 grams) of the waste material in potassium hydroxide and dissolving, or digesting, the resultant fluxed material in hydrochloric acid. Total alpha activity was then determined on a liquid aliquot of the dissolved waste material.

Laboratory control standards and duplicate analysis quality control checks were applied to TGA, DSC, and total alpha activity analyses. Analysis of laboratory blanks and spikes was also applied to the total alpha activity analysis. For assessment of the quality control data, see Section 5.0 and Table A-1. 
The tank characterization plan required the analysis of all subsamples for lithium and bromide to determine the extent of HHF contamination (Schreiber 1995). Lithium was determined by inductively coupled plasma (ICP) and bromide by ion chromatography. These results are provided in Appendix A. Only segment 15 and the liquid in the cask liner showed large amounts of HHF.

Concentrations of HHF in segment 15 were too large to make accurate data corrections. Because of the HHF contamination in the sample, segment 15 results do not represent accurate estimates of the tank contents and should not be used. Segment 15 sample material was not included in the solids composite. Lithium and bromide concentrations were so low in other samples that data corrections were not necessary.

In addition to the safety screening analyses, the flammable gas DQO (McDuffie and Johnson 1994) and the tank characterization plan (Schreiber 1995) call out a number of additional assays to be performed. Selected subsamples and strata were analyzed for a variety of analytes including ICP metals, IC anions, radionuclides, TIC, TOC, hydroxide, cyanide, chromium IV, pH, and density. Physical characterization, that is, the determination of density, solids settling rate, viscosity, shear strength, and volume percent solids, was also performed on composited segments 10 through 14 (stratum D).

All reported analyses were completed using approved laboratory procedures (see Table 3-4). No deviations or modifications to the procedures were noted by the laboratory, except for DSC samples S95T000085 and S95T000105 which were inadvertently run in air.

\subsection{DESCRIPTION OF JUNE 1994 AUGER SAMPLING EVENT}

The auger samples were obtained from June 2, 1994, through June 9, 1994, using risers 7B, 14A, and 22A (Bell 1994). The samples were taken to address "crust burn," the possibility of the waste crust in the tank becoming hot enough during intrusive (core) sampling activities to initiate an exothermic reaction or to ignite the radiolytically produced hydrogen gas (Schreiber 1994a). An auger sample was considered a satisfactory and safe way to evaluate the waste crust.

No problems with the sampling event were noted, except for a kinked bounding spring in the auger sampler for riser $22 \mathrm{~A}$ which made it difficult to remove the auger from the sleeve.

Table 3-5 lists the sample date, extrusion date, sample mass, and a description of the sample. Table 3-6 provides additional information about the auger sampling event. 
Table 3-5. Description of June 1994 Auger Samples'.

\begin{tabular}{|c|c|c|c|c|}
\hline priser & $\begin{array}{l}\text { Samplo } \\
\text { Bate? }\end{array}$ & $\begin{array}{l}\text { Muritision } \\
\text { Bate' }\end{array}$ & Somple & Sariple Bescupption \\
\hline $7 \mathrm{~B}$ & $6 / 8 / 94$ & $6 / 9 / 94$ & 10.7 & $\begin{array}{l}\text { Hard, dry brittle crust on flutes } 1 \text { to } 4 \text { and } \\
6 \text {, white to light gray color. Different } \\
\text { texture than subsequent samples. }\end{array}$ \\
\hline $14 \mathrm{~A}$ & $6 / 6 / 94$ & $6 / 7 / 94$ & 9.05 & $\begin{array}{l}95 \text { percent of material on flute } 2 \text {, white to } \\
\text { light brown color. Smaller amounts on } \\
\text { flutes } 1 \text { and } 3 \text {. }\end{array}$ \\
\hline $22 \mathrm{~A}$ & $6 / 2 / 94$ & $6 / 7 / 94$ & 20.5 & $\begin{array}{l}4 \text { to } 5 \mathrm{~mL} \text { liquid in liner not recovered. } \\
\text { White, crusty material recovered from } \\
\text { flutes } 1 \text { to } 3 \text {; white and dark brown } \\
\text { material from flute } 4 \text {; dark brown material } \\
\text { from flutes } 5 \text { to } 8 \text {. }\end{array}$ \\
\hline
\end{tabular}

Notes:

'Bell (1994)

${ }^{2}$ Dates are in the $\mathrm{mm} / \mathrm{dd} / \mathrm{yy}$ format.

Table 3-6. Tank 241-SY-103 June 1994 Auger Sampling Information'.

\begin{tabular}{|c|c|c|c|c|c|}
\hline Piser & Samile & $\begin{array}{l}\text { Shipnent } \\
\text { Tumber }\end{array}$ & 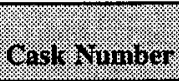 & Wasis Sen & 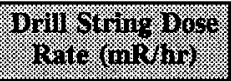 \\
\hline $22 \mathrm{~A}$ & 94-AUG-001 & 33783 & C-1046 & 2297 & 160 \\
\hline $14 \mathrm{~A}$ & 94-AUG-002 & 43663 & C-1043 & 3756 & 60 \\
\hline $7 \mathrm{~B}$ & 94-AUG-003 & $\mathrm{n} / \mathrm{a}$ & C-1054 & $\mathrm{n} / \mathrm{a}$ & $n / a$ \\
\hline
\end{tabular}

Notes:

$\mathbf{n} / \mathbf{a}=$ information not available

${ }^{1}$ Kocher (1994)

\subsubsection{Auger Sample Handling}

After extrusion, the auger samples were subsampled for DSC, TGA, TIC, and TOC. Two subsamples were taken from each auger sample. The auger samples from risers $7 \mathrm{~B}$ and $14 \mathrm{~A}$ were subsampled by taking one subsample from the auger itself and the second subsample 
from the extrusion tray. The auger sample from riser $22 \mathrm{~A}$ was subsampled by taking both subsamples from the auger only. These six subsamples were used for the DSC and TGA analyses. Composite samples were obtained for the TIC and TOC analyses for risers 7B and $14 \mathrm{~A}$ by combining material remaining on the auger and the tray after the DSC and TGA subsamples were obtained. In the case of the auger obtained from riser $22 \mathrm{~A}$, two composites were taken. Composite 1 was composed of the white crust material on flutes 1 to 3 , and composite 2 was composed of the dark brown material from flutes 4 to 8 .

\subsubsection{Auger Sample Analysis}

Schreiber (1994a) dictated the analyses to be performed on the auger samples, and the analyses were performed according to approved 222-S Laboratory analytical procedures (Bell 1994). The TGA was performed in duplicate directly on the subsamples to determine water content. The DSC analyses were performed in duplicate directly on the samples to screen for exothermic behavior. The TIC and TOC determinations were performed directly on the composite auger samples primarily to gather additional information about the waste. Appendix B tabulates the results for these samples.

\subsection{DESCRIPTION OF THE 1986 CORE SAMPLING EVENT}

In 1986, tank 241-SY-103 was sampled by Rockwell Hanford Operations. The samples were taken to evaluate the suitability of the waste to be transported by pipeline and treated in vitrification and grouting facilities. The information from that sampling event is in this report for comparison. Pre-May 1989 data should not be used for decision-making because adequate quality control information is not available. Using push-mode core sampling, one core with 12 segments was obtained (Fow et al. 1986). Core segments 2, 7, and 12 were chosen to characterize the tank waste.

Segment 2, suspected to contain uranium sludge, was a brown slurry containing solid particles approximately $0.16 \mathrm{~cm}(0.06$ in.) in diameter. It was taken from a depth of 4.83 to $5.31 \mathrm{~m}(15.83$ to $17.42 \mathrm{ft})$ from the tank bottom.

Segment 7, thought to consist of DSS, was also brown and grainy, with larger particles and less fluid than segment 2. This segment was taken at a depth of 2.41 to $2.9 \mathrm{~m} \mathrm{(7.92} \mathrm{to}$ $9.5 \mathrm{ft})$ from the tank bottom. A large, rock-like particle about $0.64 \mathrm{~cm}(0.25 \mathrm{in}$.) in diameter and $0.25 \mathrm{~cm}(0.10$ in.) thick was found in segment 7 . Segment 12 had the appearance of dark brown chunky peanut butter mixed with sand but without the adhesive properties of peanut butter. This sample was taken from the tank bottom and was suspected to contain complexant concentrate waste. 


\subsubsection{Core Sample Handling}

Pacific Northwest National Laboratory (PNNL) personnel combined the two samples from each core segment into one container (three total) prior to characterization. Sample preparation was performed as required for each analysis. In general, chemical and radiochemical analyses were preceded by dissolution in acid or by dilution in water. Physical analyses were preceded by dilution or by oven drying.

\subsubsection{Core Sample Analysis}

Chemical and radiochemical analyses were preceded by dissolution in concentrated nitric acid and heated until the sample was dissolved or by adding water until the water-to-waste ratio was approximately 10:1 (V/V). The acid-digested samples were used for the ICP analysis and for radiochemical analyses. The 10:1 (V/V) water slurry solutions were used for ion chromatography, carbonate, and hydroxide analyses.

Physical properties measured for tank 241-SY-103 wastes were density and settling rates. Preparation for the physical tests (see Section 4.3.1) consisted of placing $5 \mathrm{~mL}$ of each of three segment samples in a 10 -mL graduated cylinder. This procedure was repeated. Three of the resulting six cylinders were dried, and the remaining three were placed in a $10^{\circ} \mathrm{C}$ $\left(50^{\circ} \mathrm{F}\right)$ water bath. Settling rate data were gathered over the next three days, then the samples were weighed, and the density was calculated.

The results of the chemical and radiochemical analyses of the 1986 samples are tabulated in Appendix C (Fow et al. 1986). Section 4.3 discusses physical properties.

\subsection{GAS MONITORING}

In addition to the online standard hydrogen monitoring system described in Section 2.4.3, a series of grab samples were taken between August and October. This information, together with the explositivity test meter measurements before sampling, are used to satisfy the flammable gas requirements for the safety screen DQO. Gas compositions (hydrogen, ammonia, and organics) are converted to a percent of the LFL for comparison to the safety screening flammable gas criteria $(<25$ percent LFL). For results from the gas monitoring, see Table $4-8$ and Section 4.4 . 


\subsection{ANALYTICAL RESULTS AND WASTE INVENTORY ESTIMATES}

\subsection{OVERVIEW}

This section summarizes the sampling and analytical results from the 1994 core sample and the June 1994 auger samples. It provides an overall estimate of each analyte concentration and the total amount of the analyte in the tank (inventory) based on the volumes of solid and liquid layers in the tank as estimated from the 1994 core sample (Rice 1995). This section also provides results from the 1994 and 1995 vapor sampling and analysis.

The convective (mixing) and nonconvective (nonmixing) layer compositions are based on the analyses of the 1994 core sampling event and are reported in Appendix A. Physical measurements were also taken on the 1994 core sample.

In deriving inventory estimates, if all values were below the detection limit, the inventory result was designated not available (n/a). If at least one value was above the detection limit, that value was used to calculate an inventory amount. The remaining inventory estimates were based on the average of two results generated from duplicate samples. No attempt was made to derive an overall estimate of variability because only one core sample was obtained from the tank. For the derivation of the tank inventory estimates, see Section 4.2.

\subsection{DATA PRESENTATION}

Tables 4-1, 4-2, and 4-3 summarize the data obtained from the analyses of the composite samples obtained from the 1994 core sample from tank 241-SY-103. Tables 4-1 and 4-2 summarize the convective and nonconvective layers. Table 4-3 estimates the inventory based on the sum of Tables 4-1 and 4-2. The "analyte method" column is the method used to determine the analyte concentration. For many metals, two methods were used to prepare the samples. The higher of the fusion (F) or acid digest (A) results was used to calculate tank inventories. Strata B and D composites were used to calculate the solids values in the convective and nonconvective layers, respectively. The drainable liquid composite sample for segments 2 to 7 was used to calculate the liquid values in the convective layer. Each segment is $48 \mathrm{~cm}$ (19 in.) long.

The projected tank inventory was based on the height of the waste at the time of the inventory $(6.86 \mathrm{~m} \mathrm{[} 22.5 \mathrm{ft}])$, which is approximately $2,820 \mathrm{~kL}(745 \mathrm{kgal})$ of waste (Schreiber 1995). The historical estimate of the tank contents on January 1994 was $2,870 \mathrm{~kL}$ (758 kgal) of waste, of which $2,184 \mathrm{~kL}$ ( $577 \mathrm{kgal}$ ) was expected to be solids (Hanlon 1995). The results of the extrusion of core 62 from tank 241-SY-103 indicate that the surveillancebased estimates of the liquid and solid layers in the tank are not very reliable. The liquid-solid interface was found in segment 9 , out of 15 segments, indicating that about half of the tank contents are supernatant. 
Table 4-1. Convective Layer Summary for Core 62. (2 Sheets)

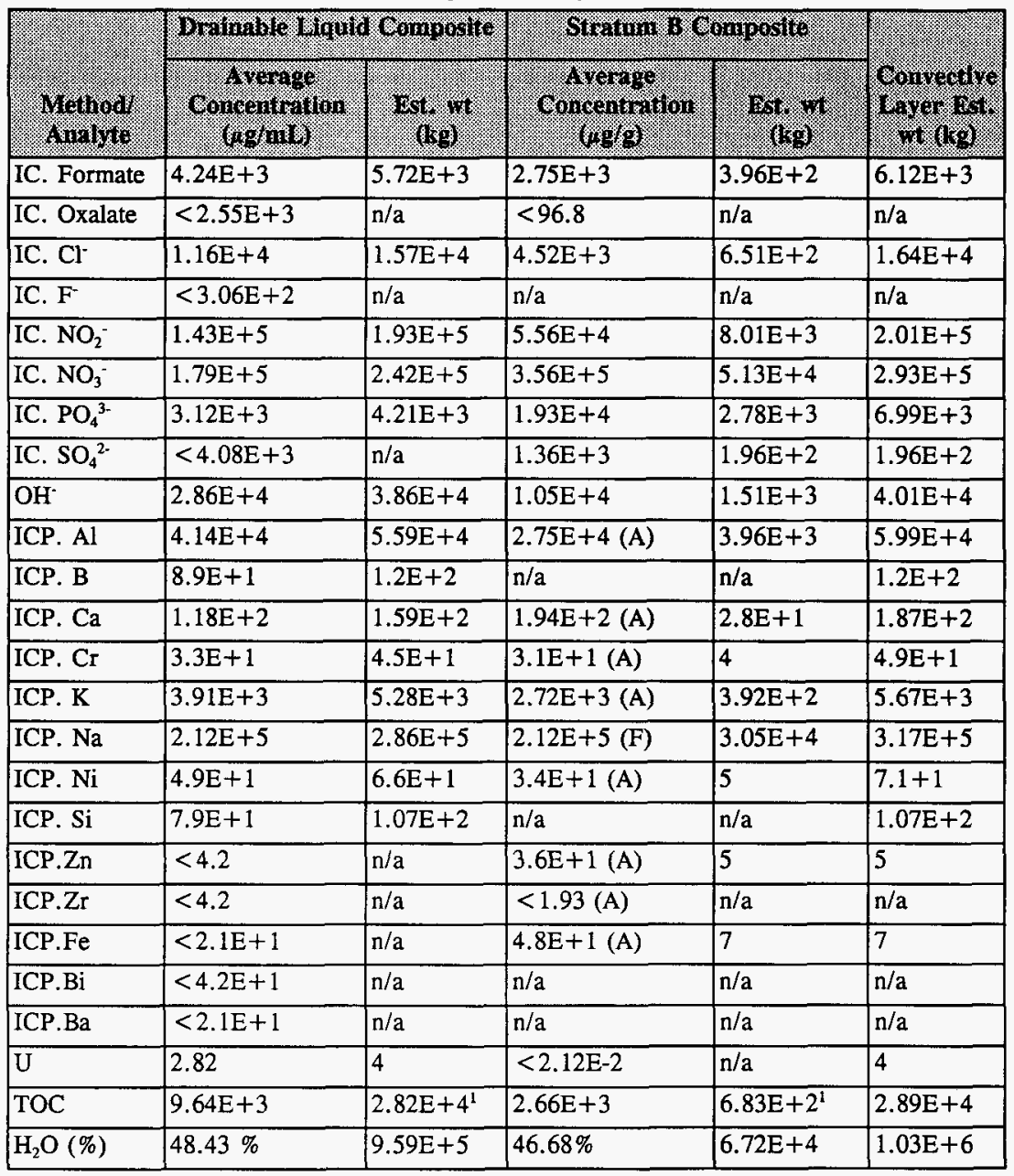


Table 4-1. Convective Layer Summary for Core 62. (2 Sheets)

\begin{tabular}{|c|c|c|c|c|c|}
\hline & 1974nalole 119 & Gomposilf & Sirquin! & 011posise & \\
\hline 40 & 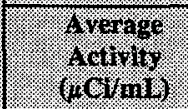 & (15) & 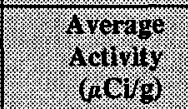 & fyong & 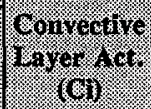 \\
\hline${ }^{241} \mathrm{Am}$ & $1.75 \mathrm{E}-3$ (D) & 2.36 & $\begin{array}{l}<2.50 \mathrm{E}-3(\mathrm{R}) \\
<1.47 \mathrm{E}-2(\mathrm{~F})\end{array}$ & $n / a$ & 2.36 \\
\hline${ }^{137} \mathrm{Cs}$ & $4.23 \mathrm{E}+2(\mathrm{D})$ & $5.71 E+5$ & $\begin{array}{l}1.76 \mathrm{E}+2(\mathrm{R}) \\
1.34 \mathrm{E}+2(\mathrm{~F})\end{array}$ & $2.53 \mathrm{E}+4(\mathrm{R})$ & $5.96 \mathrm{E}+5$ \\
\hline${ }^{60} \mathrm{Co}$ & $<1.69 \mathrm{E}-2$ (D) & $n / a$ & $\begin{array}{l}<6.26 \mathrm{E}-3 \text { (R) } \\
<2.27 \mathrm{E}-2 \text { (F) }\end{array}$ & $n / a$ & $\mathrm{n} / \mathrm{a}$ \\
\hline${ }^{243 / 244} \mathrm{Cm}$ & $<7.77 \mathrm{E}-4$ (D) & $n / a$ & $\begin{array}{l}<2.50 \mathrm{E}-3 \text { (R) } \\
<1.47 \mathrm{E}-2 \text { (F) }\end{array}$ & $n / a$ & $n / a$ \\
\hline${ }^{154} \mathrm{Eu}$ & $<8.02 \mathrm{E}-2$ (D) & $n / a$ & $\begin{array}{l}<2.67 \mathrm{E}-2 \text { (R) } \\
<5.98 \mathrm{E}-2 \text { (F) }\end{array}$ & $n / a$ & $n / a$ \\
\hline${ }^{155} \mathrm{Eu}$ & $<2.58 \mathrm{E}-1$ (D) & $n / a$ & $\begin{array}{l}<1.32 \mathrm{E}-1(\mathrm{R}) \\
<3.08 \mathrm{E}-1(\mathrm{~F})\end{array}$ & $n / a$ & $n / a$ \\
\hline${ }^{129} I$ & $1.91 \mathrm{E}-4(\mathrm{~V})$ & $2.58 \mathrm{E}-1$ & $<1.68 \mathrm{E}-1(\mathrm{~F})$ & $n / a$ & $2.58 \mathrm{E}-1$ \\
\hline${ }^{237} \mathrm{~Np}$ & $<5.93 \mathrm{E}-4$ (D) & $n / a$ & $\begin{array}{l}<2.42 \mathrm{E}-3(\mathrm{R}) \\
<1.45 \mathrm{E}-2 \text { (F) }\end{array}$ & $n / a$ & $\mathrm{n} / \mathrm{a}$ \\
\hline${ }^{238} \mathrm{Pu}$ & $<6.12 \mathrm{E}-5(\mathrm{D})$ & $n / a$ & $\begin{array}{l}<3.13 \mathrm{E}-4(\mathrm{R}) \\
3.99 \mathrm{E}-3(\mathrm{~F})\end{array}$ & $5.75 \mathrm{E}-1$ & $5.75 \mathrm{E}-1$ \\
\hline${ }^{239 / 240} \mathrm{Pu}$ & $<6.12 \mathrm{E}-5$ (D) & $n / a$ & $\begin{array}{l}<3.13 \mathrm{E}-4 \text { (R) } \\
<2.42 \mathrm{E}-3 \text { (F) }\end{array}$ & $n / a$ & $n / a$ \\
\hline${ }^{90} \mathrm{Sr}$ & 2.98 (D) & $4.02 \mathrm{E}+3$ & $\begin{array}{l}1.30(\mathrm{R}) \\
1.12(\mathrm{~F})\end{array}$ & $1.87 \mathrm{E}+2(\mathrm{R})$ & $4.21 E+3$ \\
\hline${ }^{99} \mathrm{Tc}$ & $1.63 \mathrm{E}-1$ (D) & $2.20 \mathrm{E}+2$ & $1.47 \mathrm{E}-1(\mathrm{~F})$ & $2.12 \mathrm{E}+1(\mathrm{~F})$ & $2.41 \mathrm{E}+2$ \\
\hline Tritium & $2.34 \mathrm{E}-3$ (D) & 3.16 & $<4.73 \mathrm{E}-4(\mathrm{~W})$ & $n / a$ & 3.16 \\
\hline Total alpha & $<2.52 \mathrm{E}-2(\mathrm{D})$ & $n / a$ & $<4.51 \mathrm{E}-3(\mathrm{~F})$ & $n / a$ & $n / a$ \\
\hline Total beta & $4.24 \mathrm{E}+2(\mathrm{D})$ & $5.72 \mathrm{E}+5$ & $1.71 \mathrm{E}+2(\mathrm{~F})$ & $2.46 E+4$ & $5.97 E+5$ \\
\hline
\end{tabular}

Notes:
(A) $=$ acid digest
(R) = acidified water digest
(D) = diluted with acid
(V) = water dilution-no acid added
(F) $=$ fusion in Ni crucible
(R) $=$ acidified water digest
(W) = water digested-no acid added
$\mathrm{n} / \mathbf{a}=$ not available

${ }^{\mathrm{L}} \mathrm{As} \mathrm{kg}$ of acetate, corrected for formate contribution 
WHC-SD-WM-ER-471 Rev. 1

Table 4-2. Nonconvective Layer Summary for Core 62. (2 Sheets)

\begin{tabular}{|c|c|c|}
\hline \multirow{2}{*}{ 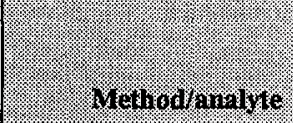 } & \multicolumn{2}{|c|}{ strituin B roingosite } \\
\hline & 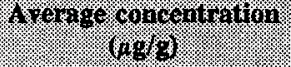 & 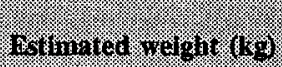 \\
\hline IC. Formate & $4.960 E+3$ & $1.07 E+4$ \\
\hline IC. Oxalate & $2.08 E+4$ & $4.47 \mathrm{E}+4$ \\
\hline IC. $\mathrm{Cl}^{-}$ & $7.03 E+3$ & $1.51 \mathrm{E}+4$ \\
\hline IC. $\mathrm{F}^{-}$ & $1.56 \mathrm{E}+3$ & $3.35 \mathrm{E}+3$ \\
\hline IC. $\mathrm{NO}_{2}^{-}$ & $8.19 E+4$ & $1.76 \mathrm{E}+5$ \\
\hline IC. $\mathrm{NO}_{3}^{-}$ & $9.81 \mathrm{E}+4$ & $2.11 \mathrm{E}+5$ \\
\hline IC. $\mathrm{PO}_{4}{ }^{3-}$ & $1.56 \mathrm{E}+4$ & $3.35 \mathrm{E}+4$ \\
\hline IC. $\mathrm{SO}_{4}{ }^{2-}$ & $7.82 \mathrm{E}+3$ & $1.68 \mathrm{E}+4$ \\
\hline $\mathrm{OH}^{-}$ & $1.84 \mathrm{E}+4$ & $3.96 \mathrm{E}+4$ \\
\hline ICP. $\mathrm{Al}(\mathrm{F})$ & $3.96 \mathrm{E}+4$ & $8.51 E+4$ \\
\hline ICP. Ca (A) & $3.5 \mathrm{E}+2$ & $7.52 \mathrm{E}+2$ \\
\hline ICP. Cr (F) & $1.02 \mathrm{E}+4$ & $2.19 E+4$ \\
\hline ICP. K (A) & $3.34 \mathrm{E}+3$ & $7.18 \mathrm{E}+3$ \\
\hline ICP. Na (A) & $1.87 \mathrm{E}+5$ & $4.02 \mathrm{E}+5$ \\
\hline ICP. Ni (A) & $1.02 \mathrm{E}+2$ & $2.19 E+2$ \\
\hline ICP.Fe (F) & $2.70 E+3$ & $5.80 \mathrm{E}+3$ \\
\hline ICP.Zn (A) & $2.3 \mathrm{E}+1$ & $4.9 E+1$ \\
\hline ICP.Zr (A) & $5.7 \mathrm{E}+1$ & $1.23 \mathrm{E}+2$ \\
\hline $\mathrm{U}$ & $7.76 \mathrm{E}+2$ & $1.67 \mathrm{E}+3$ \\
\hline TOC & $1.06 \mathrm{E}+4$ & $1.94 \mathrm{E}+4^{1}$ \\
\hline TIC & $8.80 \mathrm{E}+3$ & $9.46 \mathrm{E}+4^{2}$ \\
\hline$\overline{\mathrm{H}_{2} \mathrm{O}(\%)}$ & $32.99 \%$ & $7.09 E+5$ \\
\hline
\end{tabular}


Table 4-2. Nonconvective Layer Summary for Core 62. (2 Sheets)

\begin{tabular}{|c|c|c|}
\hline \multirow{2}{*}{ 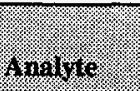 } & \multicolumn{2}{|c|}{ Stratim D composito } \\
\hline & 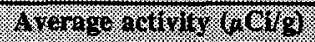 & 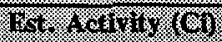 \\
\hline${ }^{241} \mathrm{Am}$ & $6.68 \mathrm{E}-1(\mathrm{~F})$ & $1.44 E+3(F)$ \\
\hline${ }^{137} \mathrm{Cs}$ & $\begin{array}{l}2.50 \mathrm{E}+2(\mathrm{R}) \\
2.32 \mathrm{E}+2(\mathrm{~F})\end{array}$ & $5.38 \mathrm{E}+5(\mathrm{R})$ \\
\hline${ }^{60} \mathrm{Co}$ & $\begin{array}{l}2.28 \mathrm{E}-2(\mathrm{R}) \\
4.90 \mathrm{E}-2(\mathrm{~F})\end{array}$ & $1.05 \mathrm{E}+2(\mathrm{~F})$ \\
\hline $243 / 244 \mathrm{Cm}$ & $<2.37 \mathrm{E}-3(\mathrm{~F})$ & $\mathrm{n} / \mathrm{a}$ \\
\hline${ }^{154} \mathrm{Eu}$ & $\begin{array}{c}<5.37 \mathrm{E}-2(\mathrm{R}) \\
7.54 \mathrm{E}-1(\mathrm{~F})\end{array}$ & $1.62 \mathrm{E}+3(\mathrm{~F})$ \\
\hline${ }^{155} \mathrm{Eu}$ & $\begin{array}{l}<1.81 \mathrm{E}-1(\mathrm{R}) \\
6.55 \mathrm{E}-1(\mathrm{~F})\end{array}$ & $1.41 \mathrm{E}+3(\mathrm{~F})$ \\
\hline${ }^{129} \mathrm{I}$ & $\begin{array}{l}<5.25 \mathrm{E}-2(\mathrm{~F}) \\
<2.23 \mathrm{E}-2(\mathrm{~W})\end{array}$ & $\mathrm{n} / \mathrm{a}$ \\
\hline${ }^{237} \mathrm{~Np}$ & $\begin{array}{l}<2.60 \mathrm{E}-3(\mathrm{R}) \\
<1.20 \mathrm{E}-2(\mathrm{~F})\end{array}$ & $\mathrm{n} / \mathrm{a}$ \\
\hline${ }^{238} \mathrm{Pu}$ & $\begin{array}{l}5.07 \mathrm{E}-4(\mathrm{R}) \\
1.62 \mathrm{E}-2(\mathrm{~F})\end{array}$ & $3.48 \mathrm{E}+1(\mathrm{~F})$ \\
\hline${ }^{239 / 240} \mathrm{Pu}$ & $\begin{array}{l}9.41 \mathrm{E}-4(\mathrm{R}) \\
6.23 \mathrm{E}-2(\mathrm{~F})\end{array}$ & $1.34 \mathrm{E}+2(\mathrm{~F})$ \\
\hline${ }^{90} \mathrm{Sr}$ & $\begin{array}{c}2.16(\mathrm{R}) \\
3.48 \mathrm{E}+1(\mathrm{~F})\end{array}$ & $7.48 \mathrm{E}+4(\mathrm{~F})$ \\
\hline${ }^{99} \mathrm{Tc}$ & $\begin{array}{l}2.44 \mathrm{E}-1(\mathrm{~F}) \\
1.35 \mathrm{E}-1 \text { (R) }\end{array}$ & $5.25 \mathrm{E}+2(\mathrm{~F})$ \\
\hline Tritium & $\mathrm{n} / \mathrm{a}$ & $\mathrm{n} / \mathrm{a}$ \\
\hline Total alpha & $5.68 \mathrm{E}-1(\mathrm{~F})$ & $1.22 \mathrm{E}+3(\mathrm{~F})$ \\
\hline Total beta & $4.32 \mathrm{E}+2(\mathrm{~F})$ & $9.29 \mathrm{E}+5$ \\
\hline
\end{tabular}

Notes:

(A) = acid digest

(F) = fusion in a Ni crucible

(R) = water digest acidified for radchem

$(W)=$ water digest - no acid added

$\mathrm{n} / \mathrm{a}=$ not available-all results below the detection limit

'As kg of acetate, corrected for formate and oxalate contribution

${ }^{2} \mathrm{As} \mathrm{kg}$ of carbonate 


\section{WHC-SD-WM-ER-471 Rev. 1}

Table 4-3. Tank 241-SY-103 Inventory Based on Core 62. (2 Sheets)

\begin{tabular}{|c|c|c|c|}
\hline 1. & $\begin{array}{l}\text { Convectiye } \\
\text { ayer lag): }\end{array}$ & 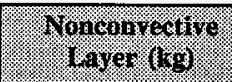 & \begin{tabular}{|l} 
rotal \\
(1)
\end{tabular} \\
\hline Formate & $6.12 \mathrm{E}+3$ & $1.07 \mathrm{E}+4$ & $1.68 \mathrm{E}+4$ \\
\hline Oxalate & $n / a$ & $4.47 \mathrm{E}+4$ & $4.47 \mathrm{E}+4$ \\
\hline $\mathrm{Cl}^{-}$ & $1.64 \mathrm{E}+4$ & $1.51 \mathrm{E}+4$ & $3.15 E+4$ \\
\hline $\mathrm{F}$ & $n / a$ & $3.35 \mathrm{E}+3$ & $3.35 \mathrm{E}+3$ \\
\hline $\mathrm{NO}_{2}$ & $2.01 E+5$ & $1.76 \mathrm{E}+5$ & $3.77 \mathrm{E}+5$ \\
\hline $\mathrm{NO}_{3}{ }^{\circ}$ & $2.93 \mathrm{E}+5$ & $2.11 \mathrm{E}+5$ & $5.04 \mathrm{E}+5$ \\
\hline $\mathrm{PO}_{4}{ }^{3-}$ & $6.99 \mathrm{E}+3$ & $3.35 E+4$ & $4.05 E+4$ \\
\hline $\mathrm{SO}_{4}{ }^{2-}$ & $1.96 \mathrm{E}+2$ & $1.68 \mathrm{E}+4$ & $1.70 \mathrm{E}+4$ \\
\hline $\mathrm{OH}^{-}$ & $4.01 \mathrm{E}+4$ & $3.96 \mathrm{E}+4$ & $7.97 \mathrm{E}+4$ \\
\hline $\mathrm{Al}$ & $5.99 E+4$ & $8.51 \mathrm{E}+4$ & $1.47 \mathrm{E}+5$ \\
\hline B & $1.2 \mathrm{E}+2$ & $n / a$ & $1.2 \mathrm{E}+2$ \\
\hline $\mathrm{Ca}$ & $1.87 \mathrm{E}+2$ & $7.52 \mathrm{E}+2$ & $9.39 \mathrm{E}+2$ \\
\hline $\mathrm{Cr}$ & $4.9 \mathrm{E}+1$ & $2.19 \mathrm{E}+4$ & $2.19 \mathrm{E}+4$ \\
\hline $\bar{K}$ & $5.67 \mathrm{E}+3$ & $7.18 \mathrm{E}+3$ & $1.28 \mathrm{E}+4$ \\
\hline $\mathrm{Na}$ & $3.17 \mathrm{E}+5$ & $4.02 E+5$ & $7.19 \mathrm{E}+5$ \\
\hline $\mathrm{Ni}$ & $7.1 \mathrm{E}+1$ & $2.19 \mathrm{E}+2$ & $2.9 \mathrm{E}+2$ \\
\hline $\mathrm{Si}$ & $1.07 \mathrm{E}+2$ & $n / a$ & $1.07 \mathrm{E}+2$ \\
\hline $\mathrm{Zn}$ & 5 & $4.9 \mathrm{E}+1$ & $5.4 \mathrm{E}+1$ \\
\hline $\mathrm{Zr}$ & $n / a$ & $1.23 \mathrm{E}+2$ & $1.23 \mathrm{E}+2$ \\
\hline $\mathrm{Fe}$ & 7 & $5.80 \mathrm{E}+3$ & $5.81 \mathrm{E}+3$ \\
\hline $\mathrm{U}$ & 4 & $1.67 \mathrm{E}+3$ & $1.67 \mathrm{E}+3$ \\
\hline TOC & $2.89 \mathrm{E}+4^{1}$ & $9.02 \mathrm{E}+3^{1}$ & $3.79 E+4^{1}$ \\
\hline TIC & $n / a$ & $9.46 \mathrm{E}+4^{2}$ & $9.46+04^{2}$ \\
\hline
\end{tabular}


Table 4-3. Tank 241-SY-103 Inventory Based on Core 62. (2 Sheets)

\begin{tabular}{|c|c|c|c|}
\hline : 1 ialic & 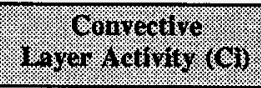 & 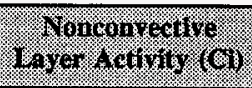 & $\begin{array}{l}\text { Total } \\
\text { ( Tctivit) }\end{array}$ \\
\hline${ }^{241} \mathrm{Am}$ & 2.36 & $1.44 \mathrm{E}+3$ & $1.44 \mathrm{E}+3$ \\
\hline${ }^{137} \mathrm{Cs}$ & $5.96 E+5$ & $5.38 \mathrm{E}+5$ & $1.13 \mathrm{E}+6$ \\
\hline${ }^{60} \mathrm{Co}$ & $\mathrm{n} / \mathrm{a}$ & $1.05 \mathrm{E}+2$ & $1.05 \mathrm{E}+2$ \\
\hline${ }^{154} \mathrm{Eu}$ & $n / a$ & $1.62 E+3$ & $1.62 \mathrm{E}+3$ \\
\hline${ }^{155} \mathrm{Eu}$ & $n / a$ & $1.41 E+3$ & $1.41 \mathrm{E}+3$ \\
\hline${ }^{129} \mathrm{I}$ & $2.58 \mathrm{E}-1$ & $\mathrm{n} / \mathrm{a}$ & $2.58 \mathrm{E}-1$ \\
\hline${ }^{238} \mathrm{Pu}$ & $5.75 \mathrm{E}-1$ & $3.48 \mathrm{E}+1$ & $3.54 \mathrm{E}+1$ \\
\hline${ }^{239 / 240} \mathrm{Pu}$ & $n / a$ & $1.34 \mathrm{E}+2$ & $1.34 \mathrm{E}+2$ \\
\hline${ }^{90} \mathrm{Sr}$ & $4.21 \mathrm{E}+3$ & $7.48 \mathrm{E}+4$ & $7.90 \mathrm{E}+4$ \\
\hline${ }^{99} \mathrm{Tc}$ & $2.41 E+2$ & $5.25 E+2$ & $7.66 \mathrm{E}+2$ \\
\hline Tritium & 3.16 & $n / a$ & 3.16 \\
\hline Total alpha & $n / a$ & $1.17 \mathrm{E}+3$ & $1.17 \mathrm{E}+3$ \\
\hline Total beta & $5.97 \mathrm{E}+5$ & $9.29 \mathrm{E}+5$ & $1.53 \mathrm{E}+6$ \\
\hline
\end{tabular}

Notes:

$\mathrm{n} / \mathbf{a}=$ not available

${ }^{1}$ As kg of acetate, corrected for formate and oxalate concentration

${ }^{2} \mathrm{As} \mathrm{kg}$ of carbonate

At the time of the 1994 core sampling, the depth of the waste was estimated to be $6.86 \mathrm{~m}$ $(22.5 \mathrm{ft})$. To estimate the tank inventory, an estimate of the liquid (convective) layer and solid (nonconvective) layer was made from the extrusion data shown (see Table 3-2). Based on the length of each segment (19 in.) and the estimated height of the liquid-solid interface in segment 9 , the height of the liquid layer (in segments) can be converted to a volume.

The density of the drainable liquid and the solids from segment 9 was approximately equal $(1.47 \mathrm{~g} / \mathrm{mL}$ vs. $1.51 \mathrm{~g} / \mathrm{mL})$; therefore, the volume of the liquid and solid (obtained from the hot cell extrusion data sheets) was used to estimate the fraction of segment 9 that was attributable to the liquid layer. In any case, the exact point of the liquid/solid interface is 
difficult to determine accurately because of solids settling and suspension variables. The tank also has cyclic height changes that may affect this interface. The following formula was used to calculate the fraction of segment 9 that is liquid. The volumes used were obtained from hot cell data sheets.

vol. liquid $/($ vol. liquid + vol. solid $)=35 /(35+250)=0.12$ segment.

The first segment was only sampled to a depth of $10 \mathrm{~cm}(4 \mathrm{in}$.$) . The height of the$ convective layer, including the crust, can be estimated at 7.12 segments plus the $10 \mathrm{~cm}$ (3.94 in.) of the first segment. Each segment is $48 \mathrm{~cm}$ (19 in.) long. This calculates to a height of $3.54 \mathrm{~m}(1.58 \mathrm{ft})$. A height of $3.54 \mathrm{~m}$ is approximately $1,450 \mathrm{~kL}$ (384 kgal). No data have been collected on the thickness of the crust layer or its composition. The historical estimate for the crust is about $15 \mathrm{~kL}$ ( $4 \mathrm{kgal}$ ), which is used in the following formula to help estimate the volume of the nonconvective layer.

$$
\text { nonconvective vol. = total vol. - (crust vol. + convective vol.). }
$$

The nonconvective volume has been estimated to be $1,370 \mathrm{~kL}$ (362 $\mathrm{kgal}$ ) by this method.

The convective layer consisted mainly of liquids with some solids present. Based on the stratum B composite, the solids represent approximately 7 percent by weight in the convective layer. Because of the small amount of solids present and the closeness in densities of the solids and liquids, the density of the convective layer can be approximated as $1.47 \mathrm{~g} / \mathrm{mL}$, which is the drainable liquid composite sample density. The solids would then represent approximately $1.44 \mathrm{E}+05 \mathrm{~kg}$ and the liquids about $1.98 \mathrm{E}+06 \mathrm{~kg}(1,350 \mathrm{~kL})$ (356 kgal) in the convective layer. This solids-corrected convective layer volume is used to calculate inventory from the drainable liquid composite sample analyses. The solids weight is used to calculate inventory contributions from stratum B composite sample analyses. The calculated volumes and masses used in determining the convective and nonconvective inventories are summarized in Table 4-4. No attempt was made to derive an estimate of variability in Table 4-3 and 4-4.

Table 4-4. Calculated Tank Volumes and Masses.

\begin{tabular}{|c|c|c|c|}
\hline & \multicolumn{2}{|c|}{ Convecuriel fayer. } & \multirow[t]{2}{*}{ Honconvectire vaver } \\
\hline & Bramabie rouid & Soligis. & \\
\hline Density $(\mathrm{g} / \mathrm{mL})$ & 1.47 & 1.51 & 1.57 \\
\hline Volume (kL) & $1.35 E+3$ & $9.6 \mathrm{E}+1$ & $1.37 \mathrm{E}+3$ \\
\hline Mass $(\mathrm{kg})$ & $1.98 \mathrm{E}+6$ & $1.44 \mathrm{E}+5$ & $2.15 \mathrm{E}+6$ \\
\hline
\end{tabular}


Solids in the convective layer were analyzed with a polarizeable light microscope and were identified as trisodium phosphate with a large amount of interstitial liquid (Rice 1995). It is possible that cooling the sample from tank temperature (approximately $34^{\circ} \mathrm{C}\left[94^{\circ} \mathrm{F}\right]$ ) to room temperature caused the solid to precipitate because trisodium phosphate is relatively insoluble at room temperature. The convective layer solids were later centrifuged to remove supernate and reanalyzed. The aluminum concentration was lower in the centrifuged solids, and sodium and phosphate were higher.

The nonconvective layer was made up of solids that varied in consistency from a thin wet mud to a damp solid that retained its shape after extrusion.

\subsection{PHYSICAL MEASUREMENTS}

Physical analyses performed on the 1994 core sample included density, viscosity, shear strength, volume percent solids, and solids settling rate (Schreiber 1995). Segments 10 through 14, the segments containing solids, were combined into a composite (stratum D) before physical measurements were made.

\subsubsection{Density, Percent Solids, and Settling Behavior}

Table 4-5 shows the bulk densities for the 1994 core composite samples. The stratum D sample density does not include any sample from the last segment because of an apparent sampling failure.

The volume-percent centrifuged solids decreased with caustic strength at a dilution ratio of 3.0:1 (V/V) from 11 percent for deionized water to 4 percent for $2 \mathrm{M} \mathrm{NaOH}$. The decrease in volume percent settled solids at 60 and $80^{\circ} \mathrm{C}$ was nearly linear, decreasing from 100 percent to about 40 percent between the dilution ratios of 0:1 (no dilution) and 1.0:1 (V/V). At $30^{\circ} \mathrm{C}$, the decrease in volume percent settled solids showed a near linear decrease from 100 percent to 40 percent between $0.15: 1$ and 1.0:1 (V/V). The volume percent settled solids was about 20 percent for all diluents at 30,60 , and $80^{\circ} \mathrm{C}$ (Bredt et al. 1995).

Table 4-5. Densities of Waste Samples for Core 62, Tank 241-SY-103.

\begin{tabular}{|l|c|}
\hline \multicolumn{1}{|c|}{ Sample. } & Density (G/m) \\
\hline Drainable liquid composite (segment 2 to 7) & 1.47 \\
\hline Drainable liquid (segment 8) & 1.47 \\
\hline Stratum A (segment 1) & 1.59 \\
\hline Stratum B (segment 4 to 8) & 1.51 \\
\hline Stratum C (segment 9) & 1.51 \\
\hline Stratum D (segment 10 to 14) & 1.57 \\
\hline
\end{tabular}




\subsubsection{Thermodynamic Analyses}

The TGA and DSC safety screening results of individual segments were reported in Rice (1994). The results are summarized in Table 4-6. The average of one solid sample had a weight percent water result below the safety screen notification limit of 17 percent water (segment 8). It did not, however, contain an exotherm, and it is in a segment that was greater than 90 percent water. One solid sample (lower half of segment 13) and one drainable liquid (segment 9 ) had a result above the safety screen notification limit of $523 \mathrm{~J} / \mathrm{g}$ (dry). This criteria has been changed to $480 \mathrm{~J} / \mathrm{g}$ in a later DQO. The lower half of segment 14 also had a result above the safety screen notification limit, but the duplicate did not, and the average was below the limit. Because no endothermic data are presented and only three of the samples did not have exotherms, the normal "-" sign (convention for exothermic enthalpy) was not used in Table 4-6 or Appendix A for DSC data.

\subsubsection{Shear Strength}

Shear strength was measured on two sets of samples from the 1994 core sampling event. The shear strength of the undisturbed samples was approximately $10,000 \mathrm{dyne} / \mathrm{cm}^{2}$, while the highest yield stress observed for the gently hand-stirred composite was only $63 \mathrm{dyne} / \mathrm{cm}^{2}$ (Bredt et al. 1995).

\subsubsection{Shear Stress Versus Shear Rate for Tank 241-SY-103}

The apparent viscosity of the samples, taken from the nonconvective layer composite sample obtained in 1994, decreased with temperature and dilution. The effect of temperature is most pronounced between and 30 and $60^{\circ} \mathrm{C}$, decreasing from 320 to $120 \mathrm{cP}$ for the undiluted sample at $400 \mathrm{~s}^{-1}$. With dilution, the decrease is most pronounced between the undiluted and $0.15: 1(\mathrm{~V} / \mathrm{V})$ sample, decreasing from 320 to $110 \mathrm{cP}$ at $400 \mathrm{~s}^{-1}$. The apparent viscosity of the composite and diluted samples decreased with increasing shear rate above a yield point. Foam formation in the samples caused an increase in apparent viscosity with increasing shear rate for the $0.50: 1,1.0: 1$, and 3.0:1 (V/V) diluted samples. The increase in apparent viscosity resulting from foam formation was seen above $300 \mathrm{~s}^{-1}$ for the 0.51 and 1.0:1 (V/V) diluted samples and above $50 \mathrm{~s}^{-1}$ for the 3.0:1 (V/V) diluted samples. 
Table 4-6. Safety Screen Results for Core 62, Tank 241-SY-103.

\begin{tabular}{|c|c|c|c|c|}
\hline Sognen & monation & 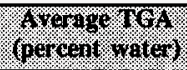 & 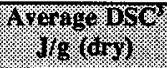 & 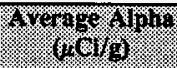 \\
\hline \multirow[b]{2}{*}{1} & Drainable liquid & 48.81 & $173(338)$ & $\mathrm{nr}$ \\
\hline & Solid & 39.18 & $118(193)$ & $<2.29 \mathrm{E}-1$ \\
\hline \multirow[b]{2}{*}{2} & Drainable liquid & 48.71 & $206(402)$ & $\mathrm{nr}$ \\
\hline & Solid & 34.30 & No exotherm & $<1.26 \mathrm{E}-1$ \\
\hline \multirow[b]{2}{*}{3} & Drainable liquid & 47.62 & $162(309)$ & $\mathrm{nr}$ \\
\hline & Solid & $\overline{19.52}$ & $43(53)$ & $<1.03 \mathrm{E}-1$ \\
\hline \multirow[b]{2}{*}{4} & Drainable liquid & 48.52 & $200(388)$ & $\mathrm{nr}$ \\
\hline & Solid & 35.24 & $57(82)$ & $<1.02 \mathrm{E}-1$ \\
\hline \multirow[b]{2}{*}{5} & Drainable liquid & 48.34 & $216(418)$ & $\mathbf{n r}$ \\
\hline & Solid & 19.69 & No exotherm & $<2.57 \mathrm{E}-1$ \\
\hline \multirow[b]{2}{*}{6} & Drainable liquid & 49.22 & $158(311)$ & $\mathrm{nr}$ \\
\hline & Solid & 29.57 & $193(276)$ & $<2.50 \mathrm{E}-1$ \\
\hline \multirow[b]{2}{*}{7} & Drainable liquid & 49.79 & $144(287)$ & $\mathrm{nr}$ \\
\hline & Solid & 26.93 & $147(224)$ & $<1.95 \mathrm{E}-1$ \\
\hline \multirow[b]{2}{*}{8} & Drainable liquid & 48.89 & $227(444)$ & $\mathrm{nr}$ \\
\hline & Solid & $15.59^{1}$ & No exotherm & $<1.38 \mathrm{E}-1$ \\
\hline \multirow[b]{2}{*}{9} & Drainable liquid & 48.83 & $286(559)^{2}$ & $\mathrm{nr}$ \\
\hline & Solid & 45.34 & $174(319)$ & $7.3 \mathrm{E}-1$ \\
\hline \multirow[b]{2}{*}{10} & Upper & 43.72 & $202(358)$ & $5.6 \mathrm{E}-1$ \\
\hline & Lower & 40.42 & $160(268)$ & $8.9 \mathrm{E}-1$ \\
\hline \multirow[b]{2}{*}{11} & Upper & 45.74 & $227(419)$ & $8.1 \mathrm{E}-1$ \\
\hline & Lower & 38.34 & $109(246)$ & $9.1 \mathrm{E}-1$ \\
\hline \multirow[b]{2}{*}{12} & Upper & 41.49 & $113(193)$ & $9.8 \mathrm{E}-1$ \\
\hline & Lower & 42.45 & $201(349)$ & $<7.53 \mathrm{E}-1$ \\
\hline \multirow[b]{2}{*}{13} & Upper & 39.81 & $196(326)$ & 1.13 \\
\hline & Lower & 40.22 & $377(630)^{2}$ & $9.1 \mathrm{E}-1$ \\
\hline \multirow[b]{2}{*}{14} & Upper & 38.80 & $149(245)$ & $9.9 \mathrm{E}-1$ \\
\hline & Lower & 41.10 & $273(464)$ & 1.54 \\
\hline \multirow[b]{2}{*}{15} & Drainable liquid & 75.06 & 181 & nr \\
\hline & Solid & 68.75 & No exotherm & $<4.88 \mathrm{E}-1$ \\
\hline
\end{tabular}

Notes:

$\mathrm{nr}=$ not requested

${ }^{1}$ Below the notification limit of 17 percent water

${ }^{2}$ Above the notification limit of $523 \mathrm{~J} / \mathrm{g}$ (dry). This value has been changed to $480 \mathrm{~J} / \mathrm{g}$ (dry) in more recent DQOs (Dukelow et al. 1995).

${ }^{3}$ All DSC results are for exotherms. The normal $(-)$ sign used for designating exothermic enthalpy is not shown. 
The Yield Power Law equation is as follows:

$$
\sigma=\alpha+\beta \gamma^{n}
$$

where

$\sigma=$ shear stress in $\mathrm{Pa}\left(\mathrm{lb}_{\mathrm{f}} / \mathrm{ft}^{2)}\right.$

$\gamma=$ shear rate

$\alpha=$ yield stress (not a fit parameter)

$\beta$ and $n$ are fit parameters

Results from the power law model are shown in Table 4-7 (Bredt et al. 1995).

The rheological parameters for diluted and undiluted 1986 samples are in Table C-7. The data indicate that segment 12 is yield-pseudoplastic, whereas the remaining samples do not exhibit a yield stress. The diluted samples number $2(1: 1)^{1}$ and number $12(1: 2)^{1}$ at 10 and $46^{\circ} \mathrm{C}\left(50\right.$ and $\left.115^{\circ} \mathrm{F}\right)$, and number $12(1: 1)^{1}$ at $10^{\circ} \mathrm{C}$ were found to be dilatant fluids, which means the fluids became more viscous at higher shear rates. The remaining diluted samples became less viscous as the shear rates increased. They are identified as pseudoplastic fluids. Apparent viscosities were calculated based on the 1986 core data for various samples and dilutions using flows of 189 and $284 \mathrm{~L} / \mathrm{min}$ (50 and $75 \mathrm{gal} / \mathrm{min}$ ), which yields a shear rate of 70 and $104 \mathrm{sec}^{-1}$ for schedule 40 pipe. The results are summarized in Table C-8.

A ball rheometer was deployed in risers $17 \mathrm{C}$ and 22A in July and August of 1995. The rheological properties of the convective layer were uniform and characterized by a viscosity of approximately $45 \mathrm{cP}$ and a yield strength of less than $2 \mathrm{~Pa}$. The nonconvective layer had a yield strength of less than $210 \mathrm{~Pa}$ and an apparent viscosity of $10^{4}$ to $10^{5} \mathrm{cP}$. The rheology of the nonconvective layer varied widely with depth and was very sensitive to shear history, more so in riser $22 \mathrm{~A}$ than $17 \mathrm{C}$. The ball rheometer was not able to penetrate a heel layer about $12 \mathrm{~m}$ thick on the tank bottom (Shepard et al. 1995).

\subsection{GAS MONITORING}

Waste tank 241-SY-103 is on the Flammable Gas Watch List. Gas release events occur in this tank every two or three months. Hydrogen and ammonia online gas monitors have been installed. Figure 4-1 shows the results from the hydrogen monitor for December, 1994 through September, 1995. Figure 4-2 shows the results from the ammonia monitor in the SY Farm exhaust stack for August 23, 1995, through September 13, 1995.

\footnotetext{
${ }^{1}$ The values inside the parentheses indicate the size of the sample dilution by volume.
} 


\begin{tabular}{|c|c|c|c|c|c|c|}
\hline $\mathrm{q}$ & $\varepsilon 89^{\circ} 0$ & $\angle Z S 0^{\circ} 0$ & $9 \varepsilon^{\circ} 0$ & $6-S I$ & 06 & dng $I: 0^{\circ} I$ \\
\hline $\mathbf{q}$ & $969^{\circ} 0$ & $8 \mathcal{E}+0^{\circ} 0$ & $I \varepsilon 0$ & $6-\varepsilon I$ & 06 & $\mathrm{I}: 0^{\circ} \mathrm{I}$ \\
\hline 9 & $6+L \cdot 0$ & $8 S E 0^{\circ} 0$ & $z z \cdot 0$ & $6-\varepsilon I$ & 09 & $\operatorname{dn} \alpha \mathrm{I}: 0^{\circ} \mathrm{I}$ \\
\hline $\mathrm{q}$ & $\angle L L{ }^{\circ} 0$ & $\$ 9200^{\circ}$ & $\nabla Z^{\prime} 0$ & 8-II & 09 & $\mathrm{I}: 0^{\circ} \mathrm{I}$ \\
\hline $\mathbf{q}$ & $208^{\circ} 0$ & $80+0^{\circ} 0$ & 910 & $\varepsilon I-\angle I$ & $O \mathcal{E}$ & $\operatorname{dn} \alpha I: 0^{\circ} I$ \\
\hline$q$ & $\varepsilon \angle 8^{\circ} 0$ & $9920^{\circ} 0$ & $\angle I^{\circ} 0$ & EI-9I & $O \varepsilon$ & $I: 0 . I$ \\
\hline 9 & $8 \nabla L^{\circ} 0$ & $8 \varepsilon+0^{\circ} 0$ & 78.0 & $Z \mathrm{I}-\mathrm{I} Z$ & 06 & dnd $1: 0 s: 0$ \\
\hline $\mathrm{q}$ & $S+8^{\circ} 0$ & $0+20^{\circ} 0$ & $\$ 8^{\circ} 0$ & $\mathrm{ZI}-0 \mathrm{Z}$ & 06 & I:0S:0 \\
\hline $\mathrm{q}$ & $8 \angle L{ }^{\circ} 0$ & $8+\varepsilon 0^{\circ} 0$ & $\angle 20$ & $\mathrm{OI}-\mathrm{SI}$ & 09 & $\mathrm{dn}_{\mathrm{C} I: 0 S: 0}$ \\
\hline $\mathrm{q}$ & $2 S L^{\circ} 0$ & $08 \varepsilon 0^{\circ} 0$ & $\tau \varepsilon^{\circ} 0$ & $O I-S I$ & 09 & I:OS:0 \\
\hline 9 & $878^{\circ} 0$ & $9910^{\circ} 0$ & $\$ 80^{\circ} 0$ & $L-6$ & $O \varepsilon$ & dnd I:0s:0 \\
\hline $\mathrm{e}$ & & & . & $\varepsilon^{\prime} t-\varsigma^{\prime} I$ & $O \varepsilon$ & I:OS:0 \\
\hline & $S E D^{\circ} 0$ & $8+6.0$ & $99^{\circ} 0$ & $\downarrow \varepsilon-\varepsilon L$ & 06 & dnd I:0₹:0 \\
\hline & $I \varepsilon L^{\circ} 0$ & $011^{\circ} 0$ & $\tau \cdot t$ & $2 \varepsilon-69$ & 06 & I:OE:0 \\
\hline & $+85^{\circ} 0$ & $180^{\circ} 0$ & $0^{\circ} \mathrm{I}$ & $\varepsilon t-L L$ & 09 & I:OE:0 \\
\hline & $006^{\circ} 0$ & $2060^{\circ} 0$ & $25^{\circ} 0$ & IS-09 & $O \varepsilon$ & dnd $[: 0 \varepsilon: 0$ \\
\hline & $\angle 26^{\circ} 0$ & $S+\angle 0^{\circ} 0$ & $\varepsilon S^{\circ} 0$ & $0 S-8 S$ & $0 \varepsilon$ & I:0\&:0 \\
\hline & I $\varepsilon 9^{\circ} 0$ & $29 \varepsilon^{\circ} 0$ & $L \cdot b$ & $z s-0 \mathrm{II}$ & 06 & 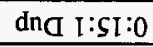 \\
\hline & $\downarrow \varepsilon 9^{\circ} 0$ & $\nabla L Z^{\circ} 0$ & $s . t$ & $z t-06$ & 06 & $\mathrm{I}: \mathrm{SI}: 0$ \\
\hline & $\mathcal{S E 9} 0$ & OSt 0 & I'z & 09-00I & 09 & dn $\mathbb{I}: \varsigma \mathrm{I}: 0$ \\
\hline & $0 \angle 9^{\circ} 0$ & zzE:0 & $9^{\circ} \mathrm{I}$ & $0 \varsigma-28$ & 09 & {$\left[: S_{I}: 0\right.$} \\
\hline & $968^{\circ} 0$ & $96 \mathrm{I}^{\circ} 0$ & $\$ 8.0$ & OI I-OEI & $0 \varepsilon$ & dnd I:sI:0 \\
\hline & $\varepsilon \angle 8^{\circ} 0$ & $I t \tau^{\circ} 0$ & $I^{\circ} \mathrm{I}$ & 0 II-0tI & $0 \varepsilon$ & $I: S I: 0$ \\
\hline & $\varepsilon \angle \varepsilon^{\circ} 0$ & $8 L^{\circ} t$ & $\varepsilon \cdot I$ & $0 Z I-0 S Z$ & 06 & $\operatorname{dn}_{\mathrm{I}} \mathrm{I}: 0$ \\
\hline & $\angle Z E^{\prime} 0$ & $86^{\circ} \mathrm{S}$ & $\varepsilon \varepsilon_{0}^{0}$ & $0 z I-0 t z$ & 06 & $\mathrm{I}: 0$ \\
\hline & $829^{\circ} 0$ & SO.I & $8^{\circ} \mathrm{t}$ & $0 \varepsilon I-0 z \tau$ & 09 & dnd $I: 0$ \\
\hline & $t[8.0$ & $682^{\circ} 0$ & $\varepsilon \cdot 9$ & 0I I -08 I & 09 & I:0 \\
\hline & $658^{\circ} 0$ & $659 \cdot 0$ & $L \cdot \varepsilon$ & $06 Z-0 \angle \varepsilon$ & $O \mathcal{E}$ & dna $\mathrm{I}: 0$ \\
\hline & $\angle \angle 9^{\circ} 0$ & $\tau \varepsilon \cdot \tau$ & $\varepsilon^{*} t$ & $0 t \varepsilon-09 \varsigma$ & $0 \varepsilon$ & $I: 0$ \\
\hline quaninom & 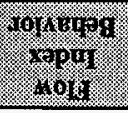 & 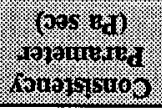 & $\begin{array}{l}\text { rail } \\
\text { ingad } \\
\text { mold }\end{array}$ & 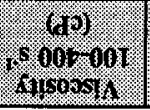 & amourarinou & moringe \\
\hline
\end{tabular}

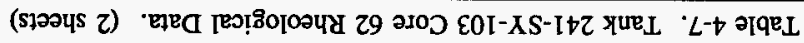


Table 4-7. Tank 241-SY-103 Core 62 Rheological Data. (2 sheets)

\begin{tabular}{|c|c|c|c|c|c|c|}
\hline Bilution. & $\begin{array}{l}\text { Temparquine } \\
\text { ( } 91)\end{array}$ & 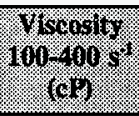 & 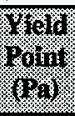 & 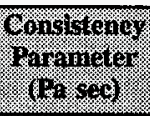 & $\begin{array}{l}\text { Tiby } \\
\text { Inadex } \\
\text { Gehrio. }\end{array}$ & Comments \\
\hline $1: 3$ & 30 & $4-6$ & & & & $a, c$ \\
\hline 1:3 Dup & 30 & $4-6$ & & & & $a, c$ \\
\hline $1: 3$ & 60 & $6-7$ & & & & $a, c$ \\
\hline 1:3 Dup & 60 & $7-7$ & & & & $a, c$ \\
\hline $1: 3$ & 90 & $7-6$ & & & & a,c \\
\hline 1:3 Dup & 90 & $5-6$ & & & & $a, c$ \\
\hline
\end{tabular}

Notes:

'Foam formation prevents modeling using yield power law.

${ }^{b}$ Model fit fails above $300 \mathrm{~s}^{-1}$, apparent dilatant behavior observed above $300 \mathrm{~s}^{-1}$.

${ }^{\circ}$ Apparent dilatant behavior observed above $50 \mathrm{~s}^{\circ 1}$. 
Figure 4-1. Tank 241-SY-103 Hydrogen Results.

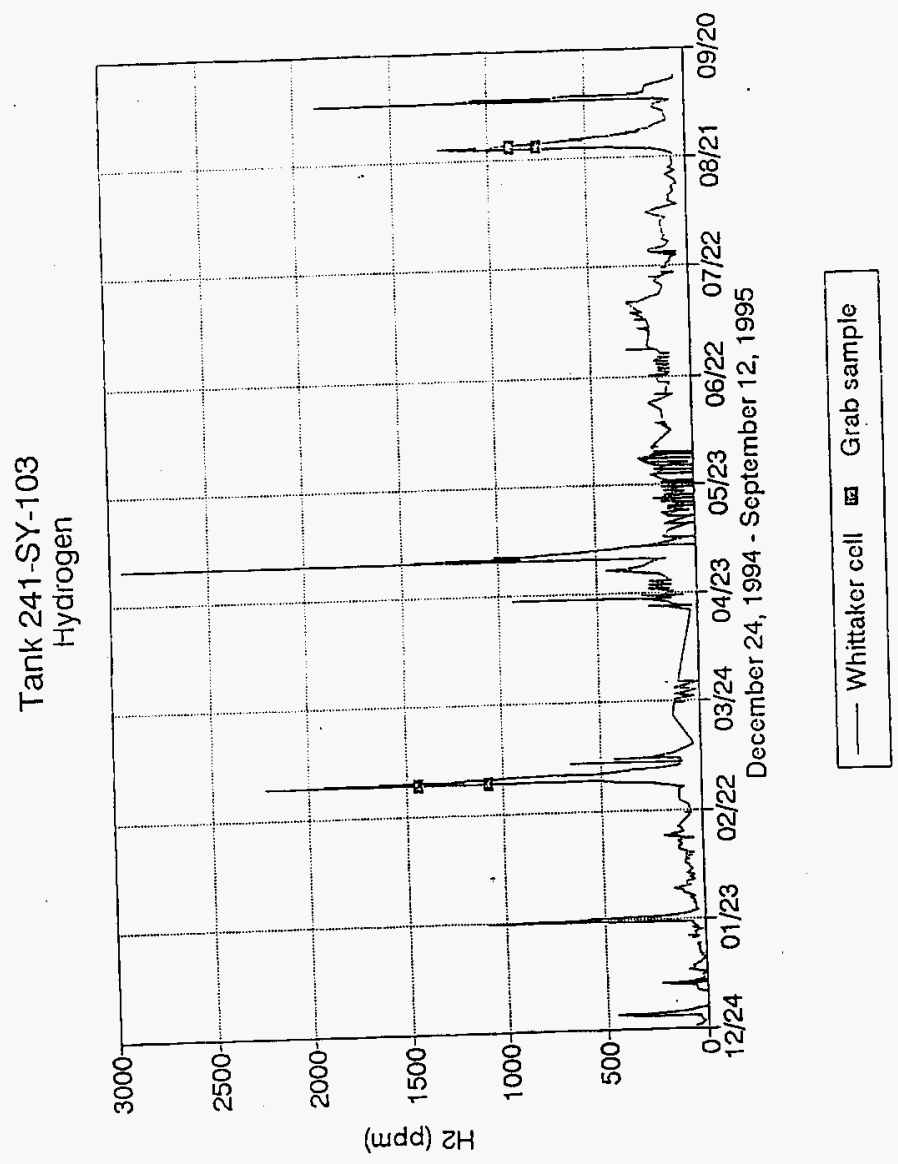




\section{WHC-SD-WM-ER-471 Rev. 1}

Figure 4-2. SY Farm Exhaust Stack Ammonia Monitor.

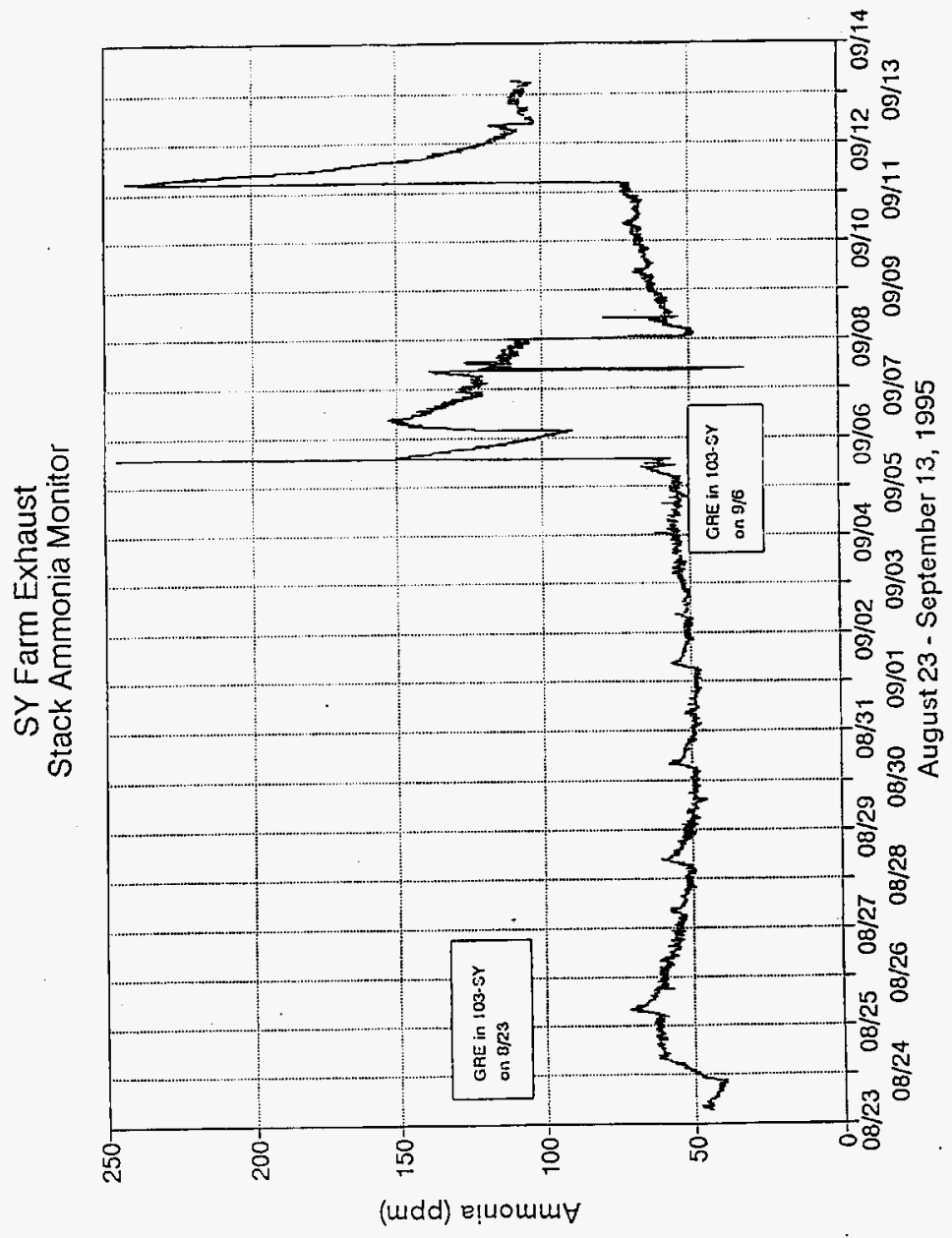


Table 4-8 shows the results of vapor grab samples taken between August and October 1994 and analyzed by mass spectrometry (Wilkins 1995a). These grab sample results were consistent with the standard hydrogen monitoring system results for that period and are $<1$ percent of the LFL.

The LFL for hydrogen is $40,000 \mathrm{ppmv}$; therefore, the 25 percent LFL limit is $10,000 \mathrm{ppmv}$. The LFL for ammonia is 150,000 ppmv, and the 25 percent limit is 37,500 ppmv. The observed concentrations of hydrogen and ammonia on the monitors are well below these limits even during gas release events.

Several important physical properties of the sludge in flammable gas tanks, including the viscosity, surface tension, and gas permeability and solubility, may be strongly affected by characteristics of the solid phases in the sludge. It has been suggested that an aluminum hydroxide gel may play an important role in gas generation and retention properties of these tanks. The crystallinity, morphology, chemical composition, and crystelline phases of several solid samples from tanks 241-SY-101 and 241-SY-103 were studied by transmission electron microscope, electron energy dispersive spectroscopy, and electron diffraction (Liu 1995). Aluminum hydroxide was found in the solids of 241-SY-103 but not in 241-SY-101. This difference was explained by the different hydroxide to aluminum ratios $(\mathrm{OH} / \mathrm{Al})$ found in the two tank samples. The lower $\mathrm{OH} / \mathrm{Al}$ of 241-SY-103 waste favors the formation of aluminum hydroxide based on aluminum solubility studies (Barney 1976).

In July and August of 1995, a void fraction instrument was operated in risers 17C and 22A. The results indicate that the nonconvective layer contains up to 12 percent void. The average void fraction was $0.047 \pm 0.015$ at riser $17 \mathrm{C}$ and $0.091 \pm 0.015$ at riser $22 \mathrm{~A}$. The stored gas volume based on these void fraction measurements is $210 \pm 60 \mathrm{M}^{3}$ at 1 atmosphere. This is consistent with the volume estimated from the observed response of waste level to atmospheric pressure (Shepard et al. 1995). The uncertainty in the measurements is expressed as one standard deviation. 
WHC-SD-WM-ER-471 Rev. 1

Table 4-8. 1994 Tank 241-SY-103 Grab Samples.

\begin{tabular}{|c|c|c|c|}
\hline Pale & P $24 \%$ & r. & Hilles 3011 \\
\hline August 18 & 19 & $<10$ & \\
\hline August 18 & 19 & $<10$ & \\
\hline August 25 & 16 & $<10$ & \\
\hline August 25 & 38 & 18 & \\
\hline September 1 & 63 & 39 & $\mathrm{CH}_{4}=11^{1}$ \\
\hline September 1 & 3 & $<10$ & \\
\hline September 7 & $<40$ & $<10$ & \\
\hline September 7 & 38 & 32 & \\
\hline September 15 & 27 & 23 & \\
\hline September 15 & 15 & $<10$ & \\
\hline September 23 & 28 & 12 & \\
\hline September 23 & 48 & 23 & \\
\hline October 6 & 16 & $<5$ & \\
\hline October 6 & 22 & 5 & \\
\hline October 19 & 22 & 4 & \\
\hline October 19 & 28 & 6 & \\
\hline
\end{tabular}

Note:

${ }^{1}$ Methane was normally reported as being less than $10 \mathrm{ppm}$. 


\subsection{INTERPRETATION OF CHARACTERIZATION RESULTS}

\subsection{ASSESSMENT OF SAMPLING AND ANALYTICAL RESULTS}

This section evaluates sampling and analysis factors that may impact data interpretation. The factors are used to assess the overall quality and consistency of the data and to identify limitations in its use.

\subsubsection{Field/Laboratory Observations}

During the extrusion of the 1994 core segments, several observations were made that could impact the data interpretation (Rice 1995). During the subsampling of the drainable liquid from segment 1 , the sample jar was inadvertently cracked at the base by the manipulator fingers. This caused most of the drainable liquid sample to be lost. The remaining drainable liquid sample had the following analyses performed on it: DSC, TGA, and ICP using an acid digest. Insufficient sample remained to do radiochemical or other water preparation analyses.

During the extrusion of segment 3 , no liquid appeared when the valve was opened. A solid plug apparently had formed. As the extrusion began, this plug was pushed onto the tray and was followed rapidly by the drainable liquid. Some of the liquid was lost out the back of the sample tray, and much of the solid was carried into the drainable liquid jar with the liquid. During the extrusion of segment 14, an air gap of 10 to $13 \mathrm{~cm}$ (4 to 5 in.) was observed after approximately $25 \mathrm{~cm}$ (10 in.) of solids.

When segment 15 was extruded, internal pressure in the sampler caused approximately $20 \mathrm{~mL}$ of sample material to be sprayed on the hot cell wall. This pressurization had not been expected and was not observed during the extrusion of the 1986 core segment of the same depth. The remaining sample from segment 15 was inconsistent with the previous segment. The analysis indicated that the liquid was mostly HHF, signifying a sampling failure. Because of the pressurization of segment 15 , an operational hold was placed on the nonsafety screening analyses of the segment, and the second core has not yet been obtained.

Segment 13 had sufficient liner liquids $(34 \mathrm{~g})$ to require analysis. The analyses indicate that it is a mixture of the HHF and some fraction of the core sample material, showing the valve had a small leak. The concentration of bromine in the segment 13 liner liquid $(0.2 \mathrm{M})$ indicates that most of the liner liquid is HHF. 


\subsubsection{Quality Control Assessment of Analytical Data}

No quality control data are available for evaluating samples analyzed at the Pacific Northwest Laboratory for the 1986 sampling event. The quality control requirements for the 1994 sampling event are defined in the tank characterization plan for tank 241-SY-103. The results are summarized in the report defined in the tank characterization plan by the method of analysis (Schreiber 1995 and Rice 1995). The 1994 raw data contain different amounts of blank, duplicate, spike, and standards data, depending on the method used to generate the results (see Appendix A and Rice [1995]). The source documents should be examined to further evaluate the quality of a given analysis. With few exceptions, the quality control objectives were met overall. The sample results with the quality control results outside the desired criteria are identified by flags in Appendix A tables.

Appendix B has quality control information for the auger sampling event. No standards for any tests were outside their limits, but the relative percent difference (RPD) for several tests on the samples exceeded 20 percent. The poor reproducibility for TGA and TOC did not affect the data use because no exotherm was observed by the DSC.

The tank characterization plan required blind standard checks for three analyses: TOC, IC, and ICP. The results are in Tables D-1, D-2, and D-3. Problems passing the TOC consistently may mean TOC results are not reliable ( 2 of 4 results were unacceptable). The water pollution blind standard results are comparable only to the liquid samples. The solid samples are prepared by a different method.

In general, the quality control data for the 1994 sampling event are consistent and show acceptable precision, especially considering the associated problems with sampling and the complex chemical and radiochemical nature of the samples. The total alpha count rates were very low in all samples and below detection limits in most, potentially impacting the inventory calculations and data interpretation. In the same samples, the beta-gamma activity was high and was predominately associated with two isotopes: ${ }^{90} \mathrm{Sr}$ and ${ }^{137} \mathrm{Cs}$ accounted for approximately 98 percent of the beta-gamma activity. Although some data are judged unreliable, all data are included in the report. Case-by-case decisions can be made on data use based on the users needs and assessment of data quality.

Several analyses suffered from poor spike recovery and/or precision. Tritium spike recoveries for solid samples showed a matrix incompatibility with the analytical method and are of little value. Although several total beta measurements gave marginal precision (approximately 20 percent or higher), most total beta data are useful in meeting the programmatic needs. Values for ${ }^{129} \mathrm{I}$ were all below or near detection limits. Occasional low precision (RPD of 20 percent or more) in ${ }^{90} \mathrm{Sr}$ determinations do not preclude data use. One ${ }^{99} \mathrm{Tc}$ duplicate gave poor precision (RPD of 28 percent), but most duplicates are adequate.

Analyses for alpha emitting isotopes were severely hampered by count rates near the detection limit and by high beta activities. Nevertheless, most alpha emitting isotope data are acceptable. The ${ }^{237} \mathrm{~Np}$ standards and spikes recoveries were not high (approximately 70 to 
80 percent); however, the data are within the expected range for the method and sample matrix. The plutonium activity for most samples was near the detection limits which results in large counting errors and differences in the results.

\subsubsection{Data Consistency Checks}

The ability to assess the overall consistency of the data between segment and composite samples is limited because not all analytes were performed on every segment. Checks can be made on some analytes when the same aliquot of sample is analyzed by two comparable analyses, or when two methods were used to prepare the sample before analysis.

Comparisons between methods may also provide information about waste chemistry. Some comparisons are provided below.

5.1.3.1 Comparison Between ICP and IC Phosphate Analyses. Table 5-1 compares the calculated phosphate concentration based on the ICP phosphorus result with phosphate data obtained from the IC for liquid samples. Phosphorus by ICP was not requested on the solid samples. The calculated ICP results, which were analyzed using an acid digest, may be greater than IC data because of small quantities of suspended insoluble phosphates or because of other phosphorus species not measured by IC. The results in Table 5-1 agree within normal analytical precision and indicate good consistency between methods.

Table 5-1. Average Phosphate Concentration $(\mu \mathrm{g} / \mathrm{mL})$.

\begin{tabular}{|c|c|c|}
\hline & $\begin{array}{l}\text { Drainable I iquid } \\
\text { Segments } 2 \text { to ? }\end{array}$ & Drantingle Uiguil \\
\hline $\mathrm{PO}_{4}^{3-}$ (calculated from ICP data) & 3530 & 3570 \\
\hline $\mathrm{PO}_{4}^{3-}$ (from IC) & 3120 & 3180 \\
\hline $\begin{array}{l}\text { \% Relative Percent Difference } \\
(100 \times(\text { calc }- \text { IC }) \times 2 /(\mathrm{calc}+\text { IC })\end{array}$ & 12 & 12 \\
\hline
\end{tabular}

5.1.3.2 Comparison of ICP Acid Digest and Fusion Methods. Table 5-2 summarizes results for the most abundant elements in each stratum. Although each stratum was mixed at the time the composite sample was created, variation in the aluminum results for the stratum B composite sample could be explained by the heterogeneous behavior of the samples. Most of the stratum $\mathrm{C}$ composite sample acid digestion results are lower than the fusion preparation. 
The metals in question should be made soluble during acid digest preparation and during fusion preparation. Duplicate results for acid and fusion in the stratum C sample agree with the original result. There is no compelling reason why the fusion preparation would be more appropriate for these metals, as demonstrated by stratum D sample results. Stratum C and stratum $\mathrm{D}$ are similar in composition, being primarily or exclusively solid material. The stratum C sample contained more liquid, however, and the sample would tend to stratify in storage. These results could be explained if the sample was not mixed thoroughly each time an aliquot was removed.

Table 5-2. Average Concentration Stratum Samples Selected Elements $(\mu \mathrm{g} / \mathrm{g})$.

\begin{tabular}{|c|c|c|c|c|}
\hline 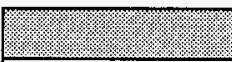 & Gratimin 4 & Siratino i & Siratimin 6 & 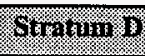 \\
\hline $\mathrm{Al} \mathrm{(F)}$ & 22200 & 12400 & 37500 & 39600 \\
\hline $\mathrm{Al}(\mathrm{A})$ & 29200 & 27500 & 25300 & 35000 \\
\hline $\mathrm{Cr}(\mathrm{F})$ & 59 & $<93$ & 5650 & 10200 \\
\hline $\mathrm{Cr}(\mathrm{A})$ & 27 & 31 & 252 & 6550 \\
\hline $\mathrm{Fe}(\mathrm{F})$ & 30 & $<274$ & 1460 & 2700 \\
\hline $\mathrm{Fe}(\mathrm{A})$ & $<18$ & 48 & 78 & 2120 \\
\hline $\mathrm{Na}(\mathrm{F})$ & 141000 & 212000 & 172000 & 140000 \\
\hline $\mathrm{Na}(\mathrm{A})$ & 150000 & 161000 & 147000 & 187000 \\
\hline
\end{tabular}

Notes:

(A) $=$ acid digest

(F) = fusion in a Ni crucible

5.1.3.3 Comparison of Acid Digest and Fusion Methods for Radiochemical Analysis. In all cases, the activities found for actinide elements were higher for samples prepared by fusion rather than acid digest. This was expected from past experience and consideration of the chemistries involved.

The ${ }^{90} \mathrm{Sr}$ values produced by fusion of solid samples from the stratum B composite sample were 14 percent lower than values yielded by acid digest. Part of this difference may be caused by subsampling errors arising from sample heterogeneity; however, this difference is also within the analytical variance expected for the method. Stratum D solid samples prepared by fusion yield higher values than those subjected to acid digest. Consideration of strontium chemistry shows this is to be expected. Fusions may provide higher results if the radionuclide is present as an insoluble compound (sulfate, fluoride etc.) which will convert to acid soluble hydroxides in the $\mathrm{KOH}$ fusion flux. 
The ${ }^{137} \mathrm{Cs}$ values for acid digested samples were slightly higher than for fused samples. This may be caused by cesium volatility.

5.1.3.4 Comparison of Total Alpha with the Sum of the Isotopes. The only significant alpha activity was associated with solids in stratum D. The sum of the individual alpha emitting isotopes exceeded the total alpha activity by 32 percent. This does not preclude using the data because the very low total alpha activities that led to high counting errors. Total alpha results may also be biased low from absorption by solids on the mount. The alpha activity for ${ }^{241} \mathrm{Am}$ in stratum D is 10 times greater than for ${ }^{239 / 240} \mathrm{Pu}$.

Table 5-3. Total Alpha/Specific Isotope Sums $(\mu \mathrm{Ci} / \mathrm{mL})$.

\begin{tabular}{|c|c|c|c|}
\hline Matrix & 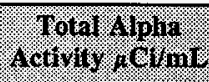 & 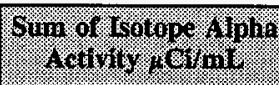 & 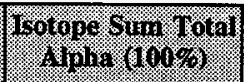 \\
\hline Stratum D solids composite & $5.68 \mathrm{E}-1$ & $7.50 \mathrm{E}-1$ & $132 \%$ \\
\hline
\end{tabular}

5.1.3.5 Comparison of Total Beta with the Sum of the Isotopes. Beta activity is associated with all samples and strata. As shown in Table 5-4, the sum of individual beta emitting isotopes and total beta are in excellent agreement for drainable liquid and solids in the stratum B composite sample. In the stratum D composite sample, the sum of the individual isotopes is only 66 percent of the total beta activity. A satisfactory explanation is not apparent at this time. One difficulty is that the precision of the total beta results for that composite is poor (RPD of 30 percent). In addition, the ${ }^{90} \mathrm{Sr}$ RPD is 15.2 percent for the sample prepared by fusion, which was used for inventory and this calculation. The ${ }^{137} \mathrm{Cs}$ RPD for the sample prepared by acid dilution, which was used for this calculation and the inventory calculation, is low (0.4 percent). It is interesting, however, that the RPD for the fused sample is 31 percent. Because most beta activity is from ${ }^{137} \mathrm{Cs}$ and the ${ }^{137} \mathrm{Cs}$ results agree reasonably well for acid and fusion, it appears that the total beta result is high and possibly in error. Generally, the agreement between acid-diluted samples and fused samples is expected to be much better.

Table 5-4. Total Beta/Specific Isotope Sums $(\mu \mathrm{Ci} / \mathrm{mL})$.

\begin{tabular}{|c|c|c|c|}
\hline Matrix & $\begin{array}{l}\text { Total Beta } \\
\text { Activity } 9 \text { C } 4 \mathrm{~mL} \text {. }\end{array}$ & $\begin{array}{l}\text { Sum of Isotope Beta } \\
\text { Activity } 4 \text { Cilint? }\end{array}$ & $\begin{array}{l}\text { Sotope Sum Total } \\
\text { neta }(100 \%)\end{array}$ \\
\hline Drainable liquid composite & $4.24 \mathrm{E}+2$ & $4.26 \mathrm{E}+2$ & $101 \%$ \\
\hline Stratum B solids composite & $1.71 E+2$ & $1.77 \mathrm{E}+2$ & $104 \%$ \\
\hline Stratum D solids composite & $4.32 E+2$ & $2.85 \mathrm{E}+2$ & $66 \%$ \\
\hline
\end{tabular}


5.1.3.6 Mass and Charge Balance. The objective in performing a mass and charge balance on the 1994 core data was to determine whether the measurements were consistent. To facilitate calculation, only the sludge phase was considered in calculating balances. Only analytes at a concentration of $1,500 \mu \mathrm{g} / \mathrm{g}$ or greater were considered.

Except for sodium and potassium, all cations listed in Table 5-5 were assumed present in their most common hydroxide or oxide form, and the concentrations of the assumed species were calculated stoichiometrically. There is some uncertainty as to whether a specific species were hydroxides or oxides, but the difference in molecular weight had a minimal effect on the overall mass balance. Smaller concentrations of other forms of the species are probably also present in the waste, but they are not included in order to keep the mass-charge balance calculations simple and consistent.

Table 5-5. Cation Mass and Charge Data (Stratum D).

\begin{tabular}{|c|c|c|c|c|}
\hline (1.2. & Comerurain & 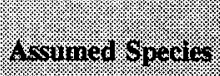 & 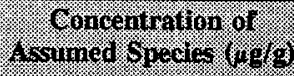 & 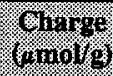 \\
\hline Aluminum & $3.96 \mathrm{E}+4$ & $\mathrm{Al}(\mathrm{OH})_{3}$ & $1.14 \mathrm{E}+5$ & 0 \\
\hline Chromium & $1.02 \mathrm{E}+4$ & $\mathrm{Cr}(\mathrm{OH})_{3}$ & $2.02 \mathrm{E}+4$ & 0 \\
\hline Potassium & $3.34 \mathrm{E}+3$ & $\mathrm{~K}^{+}$ & $3.34 \mathrm{E}+3$ & 85 \\
\hline Iron & $2.70 \mathrm{E}+3$ & $\mathrm{Fe}(\mathrm{O})(\mathrm{OH})$ & $1.70 \mathrm{E}+3$ & 0 \\
\hline Sodium & $1.87 E+5$ & $\mathrm{Na}^{+}$ & $1.87 E+5$ & 8134 \\
\hline \multicolumn{3}{|r|}{ Total } & $3.27 E+3$ & 8219 \\
\hline
\end{tabular}

Because precipitants are neutral species, all positive charge was attributed to sodium and potassium cations. The anionic analytes listed in Table 5-6 were assumed present as sodium or potassium salts and were expected to balance the positive charge. For comparison, the TOC and TIC results were converted to acetate and carbonate, respectively. In the TOC result, the data for formate and oxalate were converted to the appropriate TOC units, then subtracted prior to the TOC result being converted to acetate. The percent water was obtained from the TGA result of the solids composite in stratum D.

The ratio of microequivalents of total cations to microequivalents of total anions is 1.08 . A perfect charge balance would yield a ratio of 1.00 . The charge balance, along with the mass balance result of $0.966 \mathrm{~g} / \mathrm{g}$ in Table 5-7, demonstrates agreement among the analyses when considering the uncertainty in the assumptions and numerous measurements that were used to arrive at the values. These results indicate that large data inconsistencies or errors are not present, and that major components have been determined and evaluated properly. 
Table 5-6. Anion Mass and Charge Data (Stratum D).

\begin{tabular}{|c|c|c|}
\hline Thangte & Concentration (489) & eharge (finolly) \\
\hline TOC (acetate) & $9.02 \mathrm{E}+3^{1}$ & $1.53 E+2$ \\
\hline TIC (carbonate) & $4.40 \mathrm{E}+4^{2}$ & $1.467 \mathrm{E}+3$ \\
\hline Formate & $4.96 \mathrm{E}+3$ & $1.1 \mathrm{E}+2$ \\
\hline Oxalate & $2.08 \mathrm{E}+4$ & $4.73 E+2$ \\
\hline Chloride & $7.03 E+3$ & $1.98 \mathrm{E}+2$ \\
\hline Fluoride & $1.56 \mathrm{E}+3$ & $8.2 \mathrm{E}+1$ \\
\hline Nitrite & $8.19 \mathrm{E}+4$ & $1.78 \mathrm{E}+3$ \\
\hline Nitrate & $9.81 \mathrm{E}+4$ & $1.582 \mathrm{E}+3$ \\
\hline Phosphate & $1.56 \mathrm{E}+4$ & $4.93 \mathrm{E}+2$ \\
\hline Sulfate & $7.82 \mathrm{E}+3$ & $1.63 \mathrm{E}+2$ \\
\hline Hydroxide & $1.84 \mathrm{E}+4$ & $1.082 \mathrm{E}+3$ \\
\hline Total & $3.09 \mathrm{E}+5$ & $7.583 \mathrm{E}+3$ \\
\hline
\end{tabular}

Notes:

${ }^{1}$ Estimated as acetate, corrected for formate and oxalate

${ }^{2}$ Estimated as carbonate

Table 5-7. Mass Balance Totals.

\begin{tabular}{|l|c|}
\hline \multicolumn{1}{|c|}{ Totak. } & Coneentrations gramo per grom \\
\hline Total from Table 5-5 & 0.327 \\
\hline Total from Table 5-6 & 0.309 \\
\hline Water (33\%) & 0.330 \\
\hline Grand Total & 0.966 \\
\hline
\end{tabular}




\subsection{COMPARISON OF SAMPLING EVENTS}

The use of composite samples in the 1994 sample event makes it difficult to compare results in the solids to the individual segments analyzed from the 1986 sampling event. Table 5-8 compares the two solids results. For the chemical and radiochemical results for the 1986 core sampling event, see Appendix C.

Comparing the radiochemistry data for the 1986 event to that for stratum D of the 1994 event shows that the 1994 activities are somewhat lower than the 1986 activities. Part of this is attributable to the decay of the isotopes. Because of the uncertainties in compositing in 1994 and uncertainties in 1986 results, no rigorous comparison of the events is possible. However, no major inconsistencies appear.

Table 5-8. 1986 and 1994 Core Comparison. ${ }^{1}$

\begin{tabular}{|c|c|c|c|c|c|}
\hline \multirow{2}{*}{ 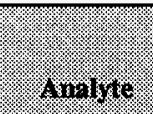 } & \multicolumn{3}{|c|}{1086.6499} & \multicolumn{2}{|c|}{$1909 /(1,18)$} \\
\hline & Sequnerl 2 & 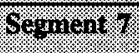 & Segmiento & Straturinge & Soranging \\
\hline $\mathrm{Al}$ & $4.45 E+4$ & $4.15 E+4$ & $4.77 \mathrm{E}+4$ & $3.75 \mathrm{E}+4$ & $3.96 \mathrm{E}+4$ \\
\hline $\mathrm{Cr}$ & $3.0 \mathrm{E}+3$ & $5.9 \mathrm{E}+3$ & $5.8 \mathrm{E}+3$ & $5.65 E+3$ & $1.02 \mathrm{E}+4$ \\
\hline $\mathrm{Fe}$ & $9.4 \mathrm{E}+2$ & $1.6 \mathrm{E}+3$ & $2.0 \mathrm{E}+3$ & $1.46 \mathrm{E}+3$ & $2.70 \mathrm{E}+3$ \\
\hline $\bar{K}$ & $3.8 \mathrm{E}+3$ & $3.4 \mathrm{E}+3$ & $2.6 \mathrm{E}+3$ & $3.04 E+3$ & $3.34 \mathrm{E}+3$ \\
\hline $\mathrm{Na}$ & $2.17 \mathrm{E}+5$ & $2.07 \mathrm{E}+5$ & $2.97 \mathrm{E}+5$ & $1.60 \mathrm{E}+5$ & $1.87 E+5$ \\
\hline $\mathrm{Ni}$ & $8.0 \mathrm{E}+1$ & $1.30 \mathrm{E}+2$ & $1.20 \mathrm{E}+2$ & $2.9 \mathrm{E}+1$ & $1.02 \mathrm{E}+2$ \\
\hline $\mathrm{Cl}^{-}$ & $7.3 \mathrm{E}+3$ & $6.8 \mathrm{E}+3$ & $5.3 \mathrm{E}+3$ & $7.4 \mathrm{E}+3$ & $7.0 E+3$ \\
\hline $\mathrm{NO}_{2}{ }^{\circ}$ & $8.35 E+4$ & $7.91 E+4$ & $7.31 \mathrm{E}+4$ & $7.99 \mathrm{E}+4$ & $8.19 E+4$ \\
\hline $\mathrm{NO}_{3}^{-}$ & $1.0 \mathrm{E}+5$ & $1.0 \mathrm{E}+5$ & $2.5 \mathrm{E}+5$ & $9.64 \mathrm{E}+4$ & $9.81 \mathrm{E}+4$ \\
\hline $\mathrm{PO}_{4}{ }^{3-}$ & $3.1 \mathrm{E}+3$ & $3.8 \mathrm{E}+3$ & $4.2 \mathrm{E}+3$ & $8.44 E+3$ & $1.56 \mathrm{E}+4$ \\
\hline $\mathrm{SO}_{4}^{2-}$ & $2.4 \mathrm{E}+3$ & $4.6 \mathrm{E}+3$ & $3.8 \mathrm{E}+3$ & $6.38 \mathrm{E}+3$ & $7.82 \mathrm{E}+3$ \\
\hline$\overline{\mathrm{OH}^{-}}$ & $2.10 \mathrm{M}$ & $2.06 \mathrm{M}$ & $1.55 \mathrm{M}$ & $1.79 \mathrm{M}$ & $1.63 \mathrm{M}$ \\
\hline
\end{tabular}

Note:

' 1986 data should be used with caution because the level of quality is uncertain and because of later waste additions. 


\subsection{TANK WASTE PROFILE}

The tank waste profile for tank 241-SY-103, for which approximately half the contents is contained in a nonconvective layer, is difficult to estimate. The ability to evaluate the horizontal distribution of waste components is limited by the number of risers sampled (14A and 17A), while the vertical stratification depends on the number of segments or subsegments analyzed. Because supernatant has been added to the tank since 1986, estimates using the 1986 data are not informative.

The 1986 segment samples (2, 7, and 12) may give a better estimate of the solids stratification because the segments were chosen to sample the three suspected solids layers (see Section 3.3) The 1994 core solids were composited into two samples: one from the interface (stratum C); the other containing solids from the remaining segments (stratum D), except for the bottom segment.

The total waste composition has been estimated in Table 2-2 based on process knowledge. The uranium ion exchange sludge has not been estimated. The CCPLX layer is expected to be on the bottom and the DSS layer above it. The main features of the CCPLX waste estimate are the lack of aluminum, the presence of organics, and lower levels of nitrite and hydroxide, when compared to the DSS. Table 5-8 shows no significant difference for these analytes among segments 2,7 , and 12 . This indicates that substantial mixing has occurred between the solids layers.

Organics were not measured in the 1986 core sample, but they were part of the composite samples in the 1994 core. The safety screen analyses did include DSC, which gives a relative idea of organics stratification in the solids layer. The DSC analyses were done on each half segment, and the results are in Table 4-6. Only the lower halves of segments 13 and 14 indicate increased organics. Unfortunately, segment 15 data, expected to have the most organics, is suspect because of sampling problems associated with it. The alpha results show no trends, but they are higher in the solids layer (segments 9 to 14) than in the supernate.

Uranium was not measured in the 1986 core sample. Table 5-9 lists the average uranium results of the 1994 strata solids. There appears to be no difference between the stratum C sample, which is expected to contain the uranium resin sludge, and the stratum D sample.

Data indicate that two relatively homogenous phases (convective and nonconvective) are present in the tank. The nonconvective layer does not show signs of stratification, which may be caused by the mechanical mixing action experienced during gas releases.

Table 5-9. Average Concentration $(\mu \mathrm{g} / \mathrm{g})$ Solids.

\begin{tabular}{|c|c|c|c|c|}
\hline & Stratum A & Stratim B & Stratiri o & Stration D \\
\hline Uranium & 7.05 & $<.02$ & 626 & 776 \\
\hline
\end{tabular}




\subsection{COMPARISON OF ANALYTICAL AND TRANSFER HISTORY INFORMATION}

Table 5-10 compares the supernatant mixing model and the analytical composite sample results from the 1994 core (Brevick 1995). Most major constituents compare reasonably well with the computer model, except hydroxide. Among the lesser constituents, $\mathrm{Cr}^{3+}$ and $\mathrm{K}^{+}$ were found at much higher levels than predicted; $\mathrm{SO}_{4}{ }^{2+}$ was much lower. The model contains several organic constituents including citrate, EDTA, HEDTA, glycolate, and dibutyl phosphate, which were not analyzed on the 1994 core sample. Some organic results (Campbell et al. 1995) were compared to the historical model. A TOC analysis compared well with the model's prediction.

Table 5-10. Tank 241-SY-103 Inventory Comparison. ${ }^{1}$

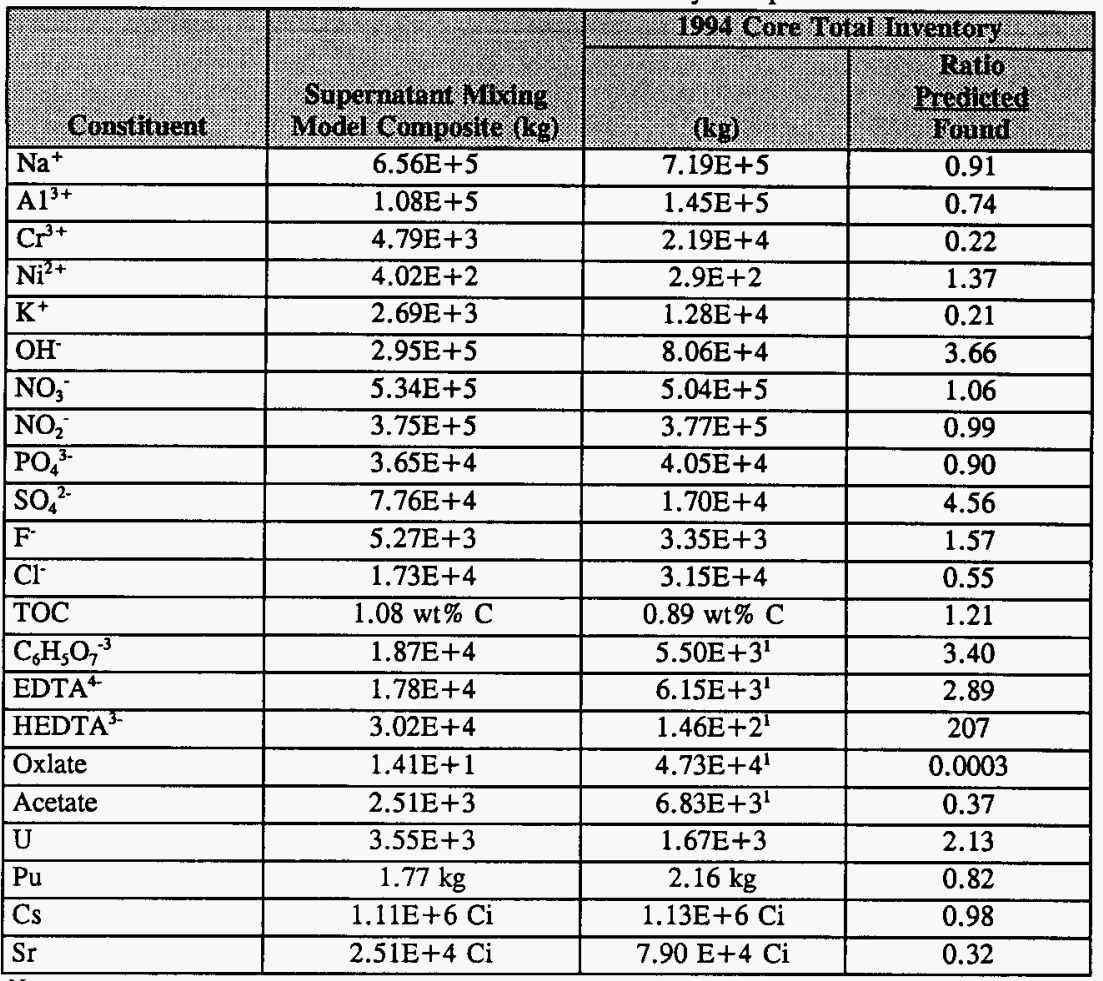

Note:

${ }^{1}$ Campbell et al. (1995) 


\subsection{EVALUATION OF PROGRAM REQUIREMENTS}

The 1994 auger sampling event was performed based on the crust burn issue DQO (Johnson 1994). The 1994 core sampling event was guided by the safety screening DQO (Babad and Redus 1994) and the flammability DQO (McDuffie and Johnson 1994). Implementation of the DQOs through tank characterization plans are summarized in Schreiber (1994a, 1994b, and 1995).

\subsubsection{Safety Evaluation}

Data criteria identified in the safety screening and flammability DQOs are used to assess the waste safety in tank 241-SY-103. The safety screening DQO requires data from two widely spaced risers, and the flammability DQO requires data from one riser. Because of the pressurization observed in the bottom segment for core 62 , it was decided not to obtain a second core from the tank; therefore, the sampling requirements of the safety screening DQO were not met. Safety screening results for the vertical subsegments for the one core indicate the two major waste layers are relatively homogeneous. Because of the large amount of water in the tank and the gas evolution events, the waste may be mixed. It is possible that the horizontal variations that would be observed by taking and analyzing a second core would be small.

Although some of the auger samples of the crust had low moisture ( $<1 T$ weight percent) content and relatively high (1 weight percent) TOC concentrations, no exothermic reactions were observed. This indicates the potential for a crust burn is low.

Table 5-11 summarizes the results for the safety screening analyses. Most samples exhibited exothermic behavior. The mean enthalpy observed for a dried sample was approximately the same ( 350 to $400 \mathrm{~J} / \mathrm{g}$ ) for the supernate and solid phases of the waste. One drainable liquid and one solid semi-segment sample exceeded the present $480 \mathrm{~J} / \mathrm{g}$ safety screening criteria. However, the weight percent water for the waste is significantly above 17 weight percent and would prevent propagation of any potential reaction.

The exothermic behavior is most likely the result of the reaction of organic complexants with nitrates/nitrites at elevated temperatures. Table $5-12$ shows the TOC is relatively high throughout the tank. The samples with larger exotherms had dry weight TOC concentrations near 2 weight percent. All of the energy estimates (except two) calculated from the TOC, assuming that the TOC is acetate, were greater than the observed exotherms by DSC. These calculated enthalpy values are based on an estimate of $1,200 \mathrm{~J} / \mathrm{g}$ energy for 4.5 weight percent TOC as acetate (Turner et al. 1995). Only small amounts of cyanide were found in the waste and do not contribute significantly to the observed exotherms.

Ion chromatography results for formate, acetate, and oxalate can account for 20 to 30 percent of the TOC in the supernate and 70 to 80 percent of the TOC in the solid phase. The solid phase contains significant quantities of oxalate, and the supernate contains none. This 
indicates that insoluble oxalates may be present in the solid waste. The oxalates and formates are degradation products of complexants such as HEDTA and EDTA and will not react as energetically with nitrate as the original complexants.

Radiolysis of water and organic degradation in the tank generate hydrogen and other gases $\left(\mathrm{NH}_{3}, \mathrm{NO}_{\mathrm{x}}\right)$ in the headspace of the tank. Combustible gas meter testing of the tank vapors before sampling measured 0 percent LFL. The safety screening DQO notification limit for flammable gas concentration is 25 percent of the LFL (Dukelow et al. 1995). The combustible gas meter used to measure gases in the tank vapor reports results as a percent of the lower explosive limit (LEL). Because the National Fire Protection Association defines the term LFL and LEL identically, the two terms are used interchangeably (NFPA 1995).

Table 5-11. Comparison of Analytical Results with Decision Criteria for the Safety Screening Data Quality Objective.

\begin{tabular}{|c|c|c|c|}
\hline \multirow{2}{*}{ 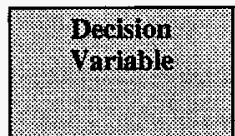 } & \multirow{2}{*}{ 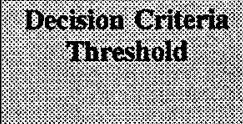 } & \multicolumn{2}{|c|}{ Wraly icat Yalues } \\
\hline & & 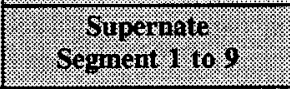 & acting \\
\hline Total Fuel & $-480 \mathrm{~J} / \mathrm{g}^{1}$ & mean $=384+53 \mathrm{~J} / \mathrm{g}^{2}$ & mean $=347+67 \mathrm{~J} / \mathrm{g}^{2}$ \\
\hline & & high $=559 \mathrm{~J} / \mathrm{g}$ & high $=630 \mathrm{~J} / \mathrm{g}$ \\
\hline Percent Moisture & 17 wt\% & $\mathrm{Av}=48.7-0.4 \mathrm{wt} \%^{2}$ & $\mathrm{Av}=41.6-1.4 \mathrm{wt} \%^{2}$ \\
\hline Total Alpha & $\begin{array}{l}1 \mathrm{~g} / \mathrm{L} \\
61.5 \mu \mathrm{Ci} / \mathrm{mL} \text { Liquid } \\
41.0 \mu \mathrm{Ci} / \mathrm{mL} \text { Solid }\end{array}$ & $<0.08 \mu \mathrm{Ci} / \mathrm{mL}^{3}$ & $\begin{array}{l}\mathrm{Av}=0.95+0.15 \\
\mu \mathrm{Ci} / \mathrm{mL}^{2}\end{array}$ \\
\hline Flammable Gas & $<25 \%$ LFL & \multicolumn{2}{|c|}{ Explosivity meter $=0 \% \mathrm{LFL}$} \\
\hline & & \multicolumn{2}{|c|}{$\begin{array}{l}\text { Highest standard hydrogen monitoring system } \\
\mathrm{H}_{2}=7.35 \% \mathrm{LFL}\end{array}$} \\
\hline & & \multicolumn{2}{|c|}{ Highest $\mathrm{NH}_{3}=0.32 \%$ LFL } \\
\hline TOC & $30,000 \mu \mathrm{g} / \mathrm{g}$ & $9,640 \mu \mathrm{g} / \mathrm{mL}(18,680)^{4}$ & $10,600 \mu \mathrm{g} / \mathrm{g}(15,820)^{4}$ \\
\hline
\end{tabular}

Notes:

'Negative values denote exothermic reaction. The $480 \mathrm{~J} / \mathrm{g}$ is based on the most recent version of the safety screening DQO (Dukelow et al 1995). A threshold of $523 \mathrm{~J} / \mathrm{g}$ was applicable at the time of the sampling event.

${ }^{2}$ Upper or lower limit to a one-sided 95 percent confidence interval on the mean.

${ }^{3}$ Total alpha on the drainable liquid composite.

${ }^{4}$ Values in parentheses are based on dry weight. 
Table 5-12. Evaluation of Organic Fuel Content in Tank 241-SY-103.

\begin{tabular}{|c|c|c|c|c|c|}
\hline Sample : & 100 & Oxilate & Morinaric. & ISC Gierot & 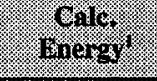 \\
\hline 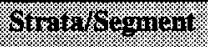 & $4 \div 49.61 .71$ & iglogr mi & 1996 or 110 & yglot. & $109.1 \%$ \\
\hline $\begin{array}{l}\text { Strata A } \\
\text { Segment 1-solids }\end{array}$ & $\begin{array}{l}4,770 \\
(7,845)\end{array}$ & $<95.8$ & $\begin{array}{l}2,920 \\
(3,993)\end{array}$ & 118 & 127 \\
\hline $\begin{array}{l}\text { Drainable liquid } \\
\text { Comp. } \\
\text { Segments } 2 \text { to } 7\end{array}$ & $\begin{array}{l}9,640 \\
(18,680)\end{array}$ & $\begin{array}{l}<2,550 \\
1,350 \text { Acetate }\end{array}$ & $\begin{array}{l}4,240 \\
(7,579)\end{array}$ & 85 & 257 \\
\hline $\begin{array}{l}\text { Strata B } \\
\text { Segments } 4 \text { to } 8 \\
\text { solids }\end{array}$ & $\begin{array}{l}2,660 \\
(4,990)\end{array}$ & $<97.1$ & $\begin{array}{l}2,750 \\
(5,159)\end{array}$ & 165 & 71 \\
\hline $\begin{array}{l}\text { Segment } 4 \\
\text { Lower solids }\end{array}$ & $\begin{array}{l}3,200 \\
(4,526)\end{array}$ & $n / a$ & $n / a$ & 57 & 85 \\
\hline $\begin{array}{l}\text { Segment } 8 \\
\text { Drainable liquid }\end{array}$ & $\begin{array}{l}10,000 \\
(19,157)\end{array}$ & $\begin{array}{l}<2,550 \\
1330 \text { Acetate }\end{array}$ & $\begin{array}{l}4,280 \\
(7700)\end{array}$ & 227 & 267 \\
\hline $\begin{array}{l}\text { Strata C } \\
\text { Segment } 9 \text { solids }\end{array}$ & $\begin{array}{l}9,580 \\
(17,514)\end{array}$ & $\begin{array}{l}23,200 \\
(42,413) \\
368 \text { Acetate }\end{array}$ & $\begin{array}{l}3,440 \\
(6289)\end{array}$ & 175 & 255 \\
\hline $\begin{array}{l}\text { Segment } 13 \\
\text { Lower solids }\end{array}$ & $\begin{array}{l}10,800 \\
(18,060)\end{array}$ & $n / a$ & $n / a$ & 377 & 288 \\
\hline $\begin{array}{l}\text { Segment } 14 \\
\text { Lower solids }\end{array}$ & $\begin{array}{l}10,300 \\
(17,487)\end{array}$ & $n / a$ & $n / a$ & 273 & 275 \\
\hline $\begin{array}{l}\text { Strata D } \\
\text { solids Comp. }\end{array}$ & $\begin{array}{l}10,600 \\
(15,820)\end{array}$ & $\begin{array}{l}20,800 \\
(31,044) \\
3,130 \text { Acetate }\end{array}$ & $\begin{array}{l}4,960 \\
(7,420)\end{array}$ & 159 & 283 \\
\hline
\end{tabular}

Notes:

( ) = Are dry weight values.

${ }^{1}$ Calculated Energy $(\mathrm{J} / \mathrm{g})=\mathrm{wt} \%$ TOC in sample $\times \frac{1,200 \mathrm{~J} / \mathrm{g}}{4.5 \mathrm{wt} \% \mathrm{TOC}}$.

A standard hydrogen monitoring system was installed on the tank in June 1994. An ammonia monitoring system also was installed on the stack exhaust for all SY tanks. For monitoring results, see Section 4.4. The highest recorded hydrogen concentration was 0.294 volume percent. This represents 7.35 percent of the LFL for hydrogen. 
The estimated ammonia concentration from tank 241-SY-103 at the peak of the May 2, 1995 gas release was 486 ppmv. This represents only 0.32 percent of the LFL for ammonia. The standard hydrogen monitoring system hydrogen results have been verified by occasional grab samples. Small quantities of methane (10 to $15 \mathrm{ppmv}$ ) have also been detected in grab samples but do not contribute significantly to the LFL. This monitoring indicates the flammability of the tank vapors are well below the 25 percent LFL limit even during the short duration gas release events. Rheology, void fraction, and other physical measurements on the waste will be used to assess the potential for gas build-up in the liquid and solid phases of the wastes.

Another factor in assessing the tank waste safety is the heat generation and temperature of the wastes. Heat is generated in the tanks primarily from radioactive decay. The primary contributors for heat generation in the tank are ${ }^{137} \mathrm{Cs}$ and ${ }^{90} \mathrm{Sr}$. The estimated heat generated from the isotopes in the tank is $5,880 \mathrm{~W}(20,100 \mathrm{Btu} / \mathrm{hr})$ as shown in Table 5-13. This is well below the $11,723 \mathrm{~W}(40,000 \mathrm{Btu} / \mathrm{hr})$ criteria for distinguishing a high heat tank from a low heat tank. Temperature monitoring indicates the waste temperature is decreasing as expected from decay of the isotopes.

Table 5-13. Heat Generation (W).

\begin{tabular}{|c|c|c|c|}
\hline 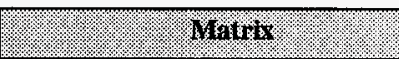 & OSTI & Totorsa & romil. W \\
\hline Drainable liquids & $2.69 \mathrm{E}+1$ & $2.70 \mathrm{E}+3$ & $2.72 \mathrm{E}+3$ \\
\hline Convective solids (stratum B) & 1.25 & $1.19 \mathrm{E}+2$ & $1.21 \mathrm{E}+2$ \\
\hline \multirow[t]{2}{*}{ Nonconvective solids (stratum D) } & $5.00 \mathrm{E}+2$ & $2.54 \mathrm{E}+3$ & $3.04 \mathrm{E}+3$ \\
\hline & & & $5.88 \mathrm{E}+3$ \\
\hline
\end{tabular}

The potential for criticality is assessed from total alpha and ${ }^{239 / 240} \mathrm{Pu}$ analyses. As expected, the highest total alpha results $(0.5$ to $1.5 \mathrm{uCi} / \mathrm{g})$ were found in the solids layer. These results are well below the $41 \mathrm{uCi} / \mathrm{g}$ notification limit for safety screening. In addition, the ${ }^{239 / 240} \mathrm{Pu}$ activity in the solids is approximately $0.06 \mathrm{uCi} / \mathrm{g}$. This and ${ }^{241} \mathrm{Am}$ analyses indicate that most total alpha activity is from ${ }^{241} \mathrm{Am}$.

\subsubsection{Operational Evaluations}

The 1986 sampling was performed to characterize the waste for retrieval and processing to create immobile waste forms suitable for disposal. The 1994 core sampling was performed to screen the tank for general safety considerations, flammable gas issues, and further process development purposes. However, the process development core (core 2) has not been sampled yet. Metal and anion analyses will support operating decisions for this tank. 
The 1994 analysis results indicate the total organic carbon content of the tank is near the $10-\mathrm{g} / \mathrm{L}$ TOC complexant waste classification limit, and the actinide levels in the sludge exceed the transuranics limit of $100 \mathrm{nCi} / \mathrm{g}$.

\subsubsection{Environmental Evaluation}

Tank 241-SY-103 was not characterized to designate waste or to evaluate environmental compliance issues. The tank has been characterized to meet regulatory requirements that the waste is safely stored and managed. No specific organic (volatile or semivolatile) analyses have been performed on the tank; therefore, no assessment can be made of these compounds.

The 1994 analyses indicate the tank meets the hydroxide specification $(12<\mathrm{pH}>14)$, with the lowest $\mathrm{pH}$ measured at 12.85 . Chromium, mostly as $\mathrm{Cr}^{3+}$, is present in relatively high concentrations in the sludge. No analysis was made for metals such as lead, mercury, cadmium, and silver.

\subsubsection{Process Development Evaluation}

The metal and anion analyses will be important in evaluating the glass disposal waste formulations and identifying potential components that may affect the treatment and disposal process. Because waste sludges may be blended, washed, and treated before disposal, there are no specific criteria. Solids samples have been taken for physical testing (Bredt et al. 1995) and to evaluate sludge washing (Lumetta and Rapko 1995). 
WHC-SD-WM-ER-471 Rev. 1

This page intentionally left blank. 


\subsection{CONCLUSION AND RECOMMENDATIONS}

The crust, supernate, and solids in tank 241-SY-103 were sampled and analyzed. Because no exotherms were observed in any auger crust sample, the potential for a crust burn was considered low, and full core sampling was performed. Only one core sample was taken in 1994 because sampling was stopped after a segment showed pressurization when extruded in the hot cells. The one core satisfied the flammability DQO but did not meet the requirements of the safety screening DQO which requires two cores from widely spaced risers. However, results for different segments of the one core indicate the waste may be reasonably homogeneous, and large differences may not exist between risers.

The DSC analyses for one drainable liquid and one semi-segment solid exceeded the safety screening criteria of $480 \mathrm{~J} / \mathrm{g}$ (dry weight). All segments in the core exhibited exotherms. TOC levels were relatively high throughout the tank but less than 3 weight percent. The weight percent water concentration for samples was well above the 17 weight percent criteria; therefore, although a fuel source is present in the waste, the water content is too high for an exothermic reaction to propagate. The thermal history of the waste does not indicate excessive temperatures, and the tank temperature is decreasing.

Flammability testing of the tank vapor using a combustible gas meter before sampling indicated 0 percent of the LFL. Hydrogen gas monitors for tank 241-SY-103 have recorded hydrogen gas concentrations in the headspace as high as 7.35 percent of the LFL. Ammonia monitors on the SY Tank Farm stack exhaust have estimated ammonia concentrations of about 0.3 percent of the LFL during a gas release event. These values are consistent with results obtained from grab samples and are well below the 25 percent LFL vapor safety criteria. Based on these results, ignition of the tank vapors is not possible.

Physical measurements on samples from the 1994 sampling event and in-tank rheology and void space measurements have been made and will be used to evaluate gas accumulation in the tank waste. Analysis of metals, TOC, and anions further support the flammability DQO.

The total alpha results and the isotopic plutonium results show that the fissile content of the waste is well below the criticality criteria for the waste. The ${ }^{241} \mathrm{Am}$ concentration in the solids is about 10 times higher than the plutonium concentration and together they exceed the transuranic waste criteria of $100 \mathrm{nCi} / \mathrm{g}$.

The data from the 1994 sampling event is sufficient to establish that the waste in its present condition does not present an immediate safety problem. Although the safety screening sample requirement of two cores was not met, the consistency of the results indicate that the waste is homogeneous for critical analytes; therefore resampling for this purpose may not be necessary. If the tank is resampled for other purposes in the future, it should be done from a second riser if possible, and the safety screening analyses should be included to verify these conclusions. 
WHC-SD-WM-ER-471 Rev. 1

This page intentionally left blank. 


\subsection{REFERENCES}

Agnew, S. F., 1995, Hanford Defined Wastes: Chemical and Radionuclide Compositions, WHC-SD-WM-TI-629, Rev. 0, Westinghouse Hanford Company, Richland, Washington.

Agnew, S. F., T. Duran, R. Corbin, K. Jurgensen, and B. Young, 1995, Waste Status and Transaction Summary for the Southeast Quadrant, WHC-SD-WM-TI-689, Rev. 1, Westinghouse Hanford Company, Richland, Washington.

Anderson, A. A., 1992, Double-Shell Underground Waste Storage Tanks Riser Survey, WHC-SD-RE-TI-093, Rev. 0, Westinghouse Hanford Company, Richland, Washington.

Anderson, J. D., 1990, A History of the 200 Area Tank Farms, WHC-MR-0132, Rev. 0, Westinghouse Hanford Company, Richland, Washington.

Babad, H., and K. S. Redus, 1994, Tank Safety Screening Data Quality Objective (DQO), WHC-SD-WM-SP-004, Rev. 0, Westinghouse Hanford Company, Richland, Washington.

Barney, S. S., 1976, Vapor-Liquid-Solid Phase Equilibrium of Radioactive Sodium Salt Wastes at Hanford, ARH-ST-133, Atlantic Richfield Hanford Company, Richland, Washington.

Bell, K., 1994, 136-Day Deliverable for Tank 241-SY-103, Auger Samples, Risers 7A, 14B, and 22A, WHC-SD-WM-DP-073, Rev. O, Westinghouse Hanford Company, Richland, Washington.

Bredt, P. R., J. D. Hudson, and J. M. Tingey, 1995 Effects of Dilution on the Physical Rheological and Chemical Properties of Tank 24I-SY-103 Waste, PNL-MIT-092995, Pacific Northwest Laboratory, Richland, Washington.

Brevick, C. H., 1995, Historical Tank Content Estimate for the Southeast Quadrant of the Hanford 200 East Areas, WHC-SD-WM-ER-350, Rev. 0, Westinghouse Hanford Company, Richland, Washington.

Campbell, J. A., S. A. Clauss, K. E. Grant, V. Hoopes, G. M. Mong, J. Rau, R. Steele, and K. L. Wahl, 1995, Flammable Gas Safety Program, Organic Analysis and Analytical Methods Development: FY 1995 Progress Report, PNL-10776, Pacific Northwest Laboratory, Richland, Washington. 
De Lorenzo, D. S., A. T. DiCenso, D. B. Hiller, K. W. Johnson, J. H. Rutherford, and D. J. Smith, 1994, Tank Characterization Reference Guide, WHC-SD-WM-TI-648, Rev. 0, Westinghouse Hanford Company, Richland, Washington.

DOE, 1994, Tank 103 Riser Equipment Arrangement, Drawing H-2-85104, Rev. 5, U.S. Department of Energy, Washington, D.C.

Dukelow, G. T., J. W. Hunt, H. Babad, J. E. Meacham, 1995, Tank Safety Screening Data Quality Objective, WHC-CD-WM-WP-004, Rev. 2, Westinghouse Hanford Company, Richland, Washington.

Ecology, EPA and DOE, 1996, Hanford Federal Facility Agreement and Consent Order, as amended, Washington State Department of Ecology, U.S. Environmental Protection Agency, and U.S. Department of Energy, Olympia, Washington.

Fow, C. L., R. D. Scheele, D. McCarthy, G. T. Thornton, W. O. Heath, and P. A. Scott, 1986, Characterization of Waste from Double-Shell Tank 103-SY, A Letter Report for Rockwell Hanford Operations, Rockwell Hanford Corporation, Richland, Washington.

Fox, G. L., D. D. Stepnewski, and R. P. Anantatmula, 1993, Tank 241-SY-103 Hazard Assessment, WHC-SD-WM-SAR, Rev. 0, Westinghouse Hanford Company, Richland, Washington.

Hanlon, B. M., 1995, Waste Tank Summary for Month Ending March 31, 1995, WHC-EP-0182-84, Westinghouse Hanford Company, Richland, Washington.

Hanlon, B. M., 1996, Waste Tank Summary for Month Ending April 31, 1996, WHC-EP-0182-97, Westinghouse Hanford Company, Richland, Washington.

Harmon, H. D., 1993, Planned Work Activities for Tank 241-SY-103, (letter 9308225B R1 and attachments, to J. H. Anttonen, U.S. Department of Energy, Richland Operations Office, November 24), Westinghouse Hanford Company, Richland, Washington.

Johnson, G. D., 1994, Data Requirements Developed Through the Data Quality Objectives Process for the Crust Burn Issue Associated with Flammable Gas Tanks, WHC-SD-WM-DQO-003, Rev. 1, Westinghouse Hanford Company, Richland, Washington.

Kocher, K. L., 1994, 45-Day Deliverable for Tank 241-SY-103, (internal memorandum to G. D. Johnson, N. G. McDuffie, and R. D. Schreiber, July 14), Westinghouse Hanford Company, Richland, Washington.

Koreski, G. M., 1995, Waste Volume Projection Historical Database, WHC-SD-WM-ER-029, Rev. 20, Westinghouse Hanford Company, Richland, Washington. 
Liu, J., L. R. Pederson, and L. Q. Qang, 1995, Solid-Phase Characterization in FlammableGas-Tank Sludges by Electron Microscopy, PNL-10723, Pacific Northwest National Laboratory, Richland, Washington.

Lumetta, G. J., and B. M. Rapko, 1995, Washing and Caustic Leaching of Hanford Tank Sludges: Results of FY 1995 Studies, PNL-10712, Pacific Northwest Laboratory, Richland, Washington.

McDuffie, N. G. and G. D. Johnson, 1994, Flammable Gas Tank Safety Programs: Data Requirements for Core Sample Anatysis Developed Through the Data Quality Objective (DQO) Process, WHC-SD-WM-DQO-004, Westinghouse Hanford Company, Richland, Washington.

Mercado, J. E., 1992, Onsite Transfer Cask SARP, WHC-SD-TP-SARP-002, Westinghouse Hanford Company, Richland, Washington.

NFPA, 1995, National Fire Codes, Vol. 10 Section 115, "Laser Fire Protection," National Fire Prevention Association, Quincy, Massachusetts.

Prignano, A. L., 1988a, Tank 103-SY Dissolution Study - Results of Physical Measurements, (Internal memorandum 12712-PCL88-011 to Distribution, November 2), Westinghouse Hanford Company, Richland, Washington.

Prignano, A. L., 1988b, Tank 103-SY Dissolution Study - Results of Chemical Analyses, (Internal memorandum 12712-PCL88-037 to K. E. Schull, December 30), Westinghouse Hanford Company, Richland, Washington.

Rice, A. D., 1994, 45-Day Safety Screen Results For Tank 241-SY-103, Core 62, (Internal memorandum 9457549 to D. R. Bratzel, November 4), Westinghouse Hanford Company, Richland, Washington.

Rice, A. D., 1995, 216-Day Final Report For Tank 241-SY-103 Push Mode, Core 62, WHC-SD-WM-DP-074, Rev. 0, Westinghouse Hanford Company, Richland, Washington.

Scaief, C. C., 1991, Temperature Measurement Error Analysis, WHC-SD-WM-TI-483, Rev. 0, Westinghouse Hanford Company, Richland, Washington.

Schreiber, R. D., 1994a, Tank 241-SY-103 Tank Characterization Plan, WHC-SD-WM-TP-197, Rev. 0A, Westinghouse Hanford Company, Richland, Washington.

Schreiber, R. D., 1994b, Tank 241-SY-103 Tank Characterization Plan, WHC-SD-WM-TP-197, Rev. 0, Westinghouse Hanford Company, Richland, Washington. 
Schreiber, R. D., 1995, Tank 241-SY-103 Tank Characterization Plan, WHC-SD-WM-TP-197, Rev. 0B, Westinghouse Hanford Company, Richland, Washington.

Shepard, C. L., C. W. Stewart, J. M. Alzhrimer, G. Terrones, and N. E. Wilkins, 1995, In Situ Determination of Rheological Properties and Void Fraction: Hanford Waste Tank 241-SY-103, Pacific Northwest Laboratory, Richland, Washington.

Strode, J. N., D. C. Riley, R. L. Shaver, and T. L. Cruzen, 1988, Waste Generation and Processing Rates with Waste Volume Reduction Factors-1988, WHC-WM-TI-309, Rev. 0, Westinghouse Hanford Company, Richland, Washington.

Tran, T. T., 1993, Thermocouple Status Single-Shell and Double-Shell Tanks, WHC-SD-WM-TI-553, Rev. 0, Westinghouse Hanford Company, Richland, Washington.

Turner, D. A., H. Babad, L. L. Buckley, and J. E. Meacham, 1995, Data Quality Objective to Support Resolution of the Organic Complexant Safety Issue, WHC-SD-WM-DQO-006, Rev. 2, Westinghouse Hanford Company, Richland, Washington.

VanVleet, R. J., 1994, Safety Basis for Activities in Double-Shell Flammable Gas Watch List Tanks, WHC-SD-WM-SARR-002, Westinghouse Hanford Company, Richland, Washington.

Welty, R. K., 1988, Waste Storage Tank Status and Leak Detection Criteria, WHC-SD-WM-TI-356, Rev. 0, Westinghouse Hanford Company, Richland, Washington.

WHC, 1994, Tank Farms Interim Safety Basis, WHC-SD-WM-ISB-001, Rev. 0, Westinghouse Hanford Company, Richland, Washington.

Wilkins, N. E., 1995a, Results of Gas Monitoring of Double-Shell Flammable Gas Watch List Tanks, WHC-SD-WM-TI-682, Rev. 0A, Westinghouse Hanford Company, Richland, Washington.

Wilkins, N. E., 1995b, Tank 241-SY-103 Core Sample: Interpretation of Results, WHC-SD-WM-TI-712, Rev. 0, Westinghouse Hanford Company, Richland, Washington. 
WHC-SD-WM-ER-471 Rev. 1

APPENDIX A

1994 CORE SAMPLING DATA 
WHC-SD-WM-ER-471 Rev. 1

This page intentionally left blank. 


\section{A.0 1994 CORE SAMPLING DATA}

\section{A.1 INTRODUCTION}

Table A-1 presents the detailed results for the analysis of each sample including applicable quality control information.

\section{A.2 COLUMN HEADINGS}

The column headings for Table A-1 are discussed below. Segment numbers and portions are identified in rows preceding each data set.

Sample \#

Identifies the 222-S Laboratory Labcore sample number.

"Q"

Identifies the quality qualifiers for the data. These qualifiers are as follows:

"a" - indicates the standard recovery was below the quality control limit

" $b "$ - indicates the standard recovery was above the quality control limit

"c" - indicates the spike recovery was below the quality control limit

" $d "$ - indicates the spike recovery was above the quality control limit

" $\mathrm{e}$ " - indicates the RPD was outside the quality control limit

" $f$ " - indicates there was blank contamination $>10$ percent of the result

The quality control limits are based on the tank characterization plan (Schreiber 1995). Standard recoveries may be outside the plan limits but still within the laboratory control limits for that procedure. Analytes near the detection limit for a method may produce RPDs that exceed the limits in the plan. Spike recoveries may not be valid indicators of accuracy when the concentration of the analyte in the sample is so large that accurate spike measurements are not possible. These conditions must be considered when evaluating data with these quality control flags. 
"Af"

"Analyte"

"Unit"

"Standard \%"

"Blank"

"Result"

"Duplicate"

"Average"

"RPD"

"Spk Rec \%"

"Det. Limit"

"Count Err\%"
This identifies the aliquot class or how the sample aliquot was treated before analysis. The following codes are used:

"A" - solid sample was prepared by acid digestion

"B" - liquid sample was prepared by acid digestion

"D" - sample was prepared by acid dilution

"F" - sample was prepared by $\mathrm{KOH}$ fusion and acid dissolution

" $R$ " - sample was digested in water then acidified for radiochemical analysis

"V" - sample was diluted in water

"W" - sample was leached or digested in water but no acid was added.

Identifies the analyte/test performed and the analytical method used. DSC exothermic data do not have the normal "-" sign convention.

This is the unit for the results.

This is the percent recovery for the standard run with the batch.

This is the result for the preparation blank prepared for the batch.

This is the test result for the sample.

This is the duplicate result for the sample.

This is the average of the sample and duplicate result.

This is the RPD between the sample and duplicate results.

This is the recovery for a spike added to the sample. Spikes may be added before or after sample preparation depending on the method.

This is the estimated detection limit for the prepared sample. This detection limit is a function of the instrument detection limit and the sample size used for analysis.

This is the error in radiochemical analysis that is derived from counting statistics. When this error is large, it indicates the sample analyzed was near its minimum detectable activity. 
Table A-1. Laboratory Data Results for Tank 241-SY-103, Core 62'.

\begin{tabular}{|c|c|c|c|c|c|c|c|c|c|c|c|c|c|}
\hline sunplet & 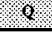 & \% & $1+14=$ & 1 & $4 \times 14 \%$ & 1) & 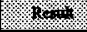 & 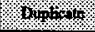 & 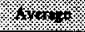 & 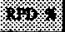 & $40 \% 5$ & 1.m. & 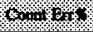 \\
\hline \multicolumn{14}{|l|}{ Segment $\# 1$} \\
\hline \multicolumn{5}{|c|}{ SEGMENT PORTION } & \multicolumn{3}{|c|}{ Drainable Liquid } & & & & & & \\
\hline$\$ 94 T 000008$ & & & \% Water by TGA using Menler & x & 98.26 & $n / 4$ & 49.45 & 48.18 & $4.88 \mathrm{E}+01$ & 2.6 & $n / \mathbf{a}$ & $1.00 \mathrm{E}-02$ & $\mathrm{n} / \mathbf{2}$ \\
\hline s94T000008 & e & & DSC Exotherm using Metrler & Joules/g & 97.7 & $n / \mathbf{s}$ & $1.36 \mathrm{E}+02$ & 210.6 & $1.73 \mathrm{E}+02$ & 43.3 & $\mathbf{n} / \mathbf{a}$ & $n / \mathbf{a}$ & $n / a$ \\
\hline S94T000009 & & D & Lithium-ICP-Acid Dil. & ug/mL & 99.8 & $1.00 \mathrm{E}-03$ & LDL & LDL & $n / 2$ & $\mathrm{n} / \mathbf{a}$ & $\mathrm{n} / \mathrm{a}$ & 11 & $\mathrm{n} / \mathbf{2}$ \\
\hline \$95T000281 & & & Tat. Organic Carbon by Coul. & $\mathrm{ug} / \mathrm{mI}$ & 99.67 & $<5.000$ & $n / a$ & $n / n$ & $\mathbf{n} / \mathbf{n}$ & $\mathrm{a} / \mathbf{\Omega}$ & $\mathbf{a} / \mathbf{a}$ & 5 & $\mathrm{n} / \mathbf{a}$ \\
\hline \$95T000281 & & & \% Water by TGA using Mettler & $\approx$ & 99.32 & $\mathbf{n} / \mathbf{a}$ & 47.4 & 46.04 & $4.67 \mathrm{E}+01$ & 2.91 & n/a & $\mathrm{n} / \mathrm{a}$ & $\mathbf{n} / \mathbf{2}$ \\
\hline S95T000281 & & & pH Dired & $\mathrm{pH}$ & 99.46 & $\mathbf{a} / \mathbf{a}$ & $\mathbf{n} / \mathbf{a}$ & $\mathbf{n} / \mathbf{n}$ & $\mathrm{n} / \mathbf{a}$ & $\mathbf{n} / \mathbf{a}$ & $\mathrm{n} / \mathbf{k}$ & $1.00 \mathrm{E}-02$ & $\mathbf{0} / \mathbf{a}$ \\
\hline S95T000281 & & & DSC Exocherm using Mettler & Joules/g & 103.7 & $\mathbf{n} / \mathbf{a}$ & 32.9 & 31.7 & $3.23 \mathrm{E}+01$ & 3.72 & $\mathbf{n} / \mathbf{2}$ & $\mathrm{n} / \mathbf{m}$ & $\mathbf{n} / \mathbf{2}$ \\
\hline S95T000323 & & B & Aluminium -ICP-Acid Digest-Liq & ug/mL & 96.4 & $1.50 \mathrm{E}-02$ & $2.42 \mathrm{E}+04$ & 24100 & $2.42 \mathrm{E}+04$ & 0.41 & $\mathbf{n} / \mathbf{a}$ & 21 & $\mathrm{n} / \mathbf{a}$ \\
\hline S95T000323 & & B & Boron -ICP-Acid Digest-Liquid & ug/ml & 94.6 & $1.00 \mathrm{E}-03$ & 56.8 & 52.6 & $5.47 \mathrm{E}+01$ & 7.68 & $n / \mathbf{n}$ & 21 & n/a \\
\hline S95T000323 & & B & Barium -ICP-Acid Digest-Liquid & ug/ml & 94.2 & $0.00 \mathrm{E}+\infty$ & $<21.00$ & $<21$ & $n / 2$ & a/a & $\mathbf{n} / \mathbf{2}$ & 21 & $n / 2$ \\
\hline$\$ 95 T 000323$ & & B & Bismuth -ICP-Acid Digest/Liq & $\mathrm{ug} / \mathrm{mL}$ & 92.8 & $-2.30 \mathrm{E}-02$ & $<42.00$ & $<42$ & $\mathbf{n} / \mathbf{n}$ & $\mathbf{a} / \mathbf{n}$ & $\mathbf{n} / \mathbf{n}$ & 42 & $n / 2$ \\
\hline s95T000323 & & B & Calcium -ICP-Acid Digest-Liq & ug/mL & 98 & $1.70 \mathrm{E}-02$ & $\mathbf{8 2 . 7}$ & 74.9 & $7.88 \mathrm{E}+01$ & 9.9 & $\mathrm{n} / \mathbf{a}$ & 42 & $n / a$ \\
\hline S95T000323 & & B & Chromium -ICP-Acid Digest-Liq & $\operatorname{Lg} / \mathrm{mL}$ & 96.8 & $0.00 \mathrm{E}+\infty$ & $1.62 E+02$ & 161 & $1.62 \mathrm{E}+02$ & 0.62 & $\mathrm{D} / \mathbf{4}$ & 4.2 & $\mathbf{b} / \mathbf{a}$ \\
\hline S95T000323 & & B & Iron -ICP-Acid Digest-Liquid & ug/mL & 95.2 & $5.00 \mathrm{E}-03$ & 49.8 & 50.1 & $5.00 \mathrm{E}+01$ & 0.6 & $\mathbf{a} / \mathbf{a}$ & 21 & $\mathbf{n} / \mathbf{s}$ \\
\hline S95T000323 & & B & Potenssium -ICP-Acid Digest-Liq & $\operatorname{ug} / \mathbf{m L}$ & 100.2 & $7.40 \mathrm{E}-02$ & $2.32 \mathrm{E}+03$ & 2310 & $2.32 \mathrm{E}+03$ & 0.43 & $a / a$ & 210 & $n / a$ \\
\hline S95T000323 & & B & Lithium -ICP-Acid Digest-Liq & $\mathbf{u g} / \mathrm{mL}$ & 94.2 & $0.00 \mathrm{E}+\infty$ & $<4.200$ & $<4.20$ & $\mathrm{n} / \mathbf{n}$ & $w / n$ & $\mathbf{w} / \boldsymbol{a}$ & 4.2 & $\mathbf{n} / \mathbf{2}$ \\
\hline
\end{tabular}




\begin{tabular}{|c|c|c|c|c|c|c|c|c|c|c|c|c|c|}
\hline$m / \pi$ & $9 \pi z$ & $8 \pi$ & sto 0 & to+azzz & $00 z z z$ & $00+ \pm \varepsilon \tau \tau$ & I0-z0z $\varepsilon$ & 9.86 & 2/an & 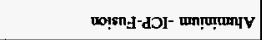 & I & & $500000 \perp 66 s$ \\
\hline w/e & $20-300 \% \mathrm{~s}$ & $v / 4$ & $\pi / 0$ & $\mathbf{y} / \mathbf{s}$ & $z-x|c\rangle\rangle$ & $20-501 s>$ & $2-\$ 0508>$ & $\infty \mathrm{I}$ & $8 /: 5 n$ & 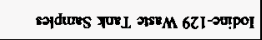 & $a$ & & 500000L.66s \\
\hline $50 \mathrm{I}$ & 10-a8z $\varepsilon$ & 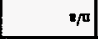 & $s=1$ & $z 0+\pi 1 b=2$ & $2+2$ & $z 0+36 \varepsilon z$ & $10-882 \cdot \varepsilon$ & 1886 & $s$ son & 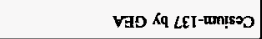 & $\mathbf{a}$ & & s00000It6s \\
\hline$\llcorner\cdot t$ & $88^{\circ} 1$ & 868 & $9 L: L$ & $20+3 \angle 6 z$ & 582 & $20+\pi 80 \mathrm{\varepsilon}$ & 05011 & $9 \varepsilon 16$ & $31: 0 \mathrm{n}$ & भdurus pqlos to mpt & $\exists$ & & s00000Lttrs \\
\hline$t \varsigma 9$ & $20-7062$ & $\pi$ & $\mathbf{8} \mathbf{u}$ & $\mathbf{v u}$ & $z$-a18z> & $20-2<8 \tau>$ & $z-2080 ; z>$ & $\nabla / \pi$ & an:on & 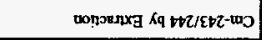 & t & & S00000Ltrs \\
\hline $\mathfrak{\varepsilon}$ & $20-206 \cdot z$ & 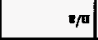 & $x / a$ & $\mathbf{x} \pi$ & $\tau \cdot a 18 \tau\rangle$ & $z 0-3<8 z>$ & $\tau \rightarrow 080 ; \tau>$ & r 201 & shon & wonversxg $k q$ Itz-wy & $\mathrm{a}$ & & $500000 \perp t 6 s$ \\
\hline $\cos$ & Iorast's & 2801 & $\pi / 0$ & 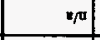 & $1-a 6 z \tau>$ & $10-26 z: 2>$ & $I-0062 \tau\rangle$ & 2.011 & spon & plos press!a jo vqdiv & $\mathrm{A}$ & 9 & s00000Itt6s \\
\hline$\approx \pi$ & $\mathrm{IE} I$ & tor & $\mathrm{rzz}$ & $00+350^{\circ} \mathrm{L}$ & $\iota r 9$ & $\varepsilon 8^{\circ} \mathrm{L}$ & $L \varepsilon \cdot \mathrm{I}$ & 1266 & $2 / 8 n$ & 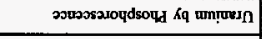 & $\mathrm{A}$ & 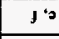 & s00000I bs \\
\hline$* \pi$ & $\pi$ & $\boldsymbol{\top}$ & 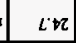 & $20+381 \div$ & tz\&I & $z 0+$ Вย: I & $\mathbf{s / u}$ & $\varepsilon z 01$ & afropnos & 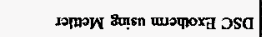 & & & to0000Itrs \\
\hline$\bullet$ & $\varepsilon 0-700^{\circ} \mathrm{I}$ & $\boldsymbol{\mu}$ & 61 & $20+3 \varepsilon 66^{\prime} 1$ & 9.112 & $z 0+a s L \cdot T$ & $* / \pi$ & $x$ & $\mathrm{xu}_{\mathrm{a}} \mathrm{s} / \mathrm{m} \mathrm{mmor}$ & 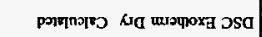 & & & to0000Ltrs \\
\hline $8 / x$ & $20-7000$ & 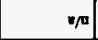 & 88.8 & $10+\pi 26 \varepsilon$ & $\forall<\varepsilon$ & 2600 & 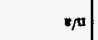 & 2001 & x & 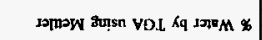 & & & $+00000 \perp t 6 s$ \\
\hline \multicolumn{14}{|c|}{ 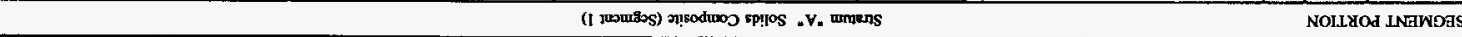 } \\
\hline$\nabla u$ & $\tau *$ & $\pi / a$ & $\pi \pi$ & 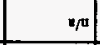 & $0 \tau t>$ & $00 \pi t>$ & $00+20000$ & 9.56 & $\mathrm{~T}^{\mathrm{w} / \mathrm{sn}}$ & 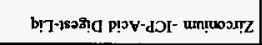 & 8 & & $\varepsilon z \varepsilon 000 \perp S 6 S$ \\
\hline $\mathbf{x} / \mathrm{u}$ & $\tau \bullet$ & $x / u$ & 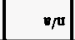 & $\pi / 0$ & Bat> & $002 \downarrow>$ & $\mathfrak{E 0 - 3 0 0 1}$ & 9.6 & $\mathrm{~T} w_{/} / a_{n}$ & 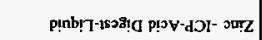 & 8 & & 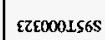 \\
\hline$* \pi$ & $0 t z$ & $\mathrm{u} / \mathrm{u}$ & $\nabla / u$ & $\nabla / 0$ & $012>$ & $20+\infty I^{\prime} z>$ & 20 -800\%1-1- & $2.26 \mathrm{I}$ & $\mathrm{T}$ & 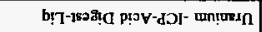 & $\mathrm{g}$ & $\mathbf{q}$ & EzE000Ls6s \\
\hline $\mathrm{\nabla} / \mathrm{u}$ & $\mathbf{I z}$ & $\mathbf{n} / \mathbf{u}$ & HEI & $10+\mathrm{a}+L^{\circ} 9$ & 6.99 & 8.29 & $20-30 t \div$ & $\tau 88$ & $\mathrm{Tw} / \mathrm{An}$ & 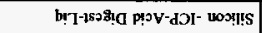 & $\mathrm{q}$ & . & EZcoool.s6s \\
\hline 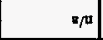 & $\$ 8$ & $\mathbf{x} / \mathbf{u}$ & $\iota 0$ & $20+\pi \varepsilon 98$ & 998 & $20+3098$ & $\varepsilon 0-300 \varepsilon$ & 256 & $T \mathrm{w} / \mathrm{sa}$ & 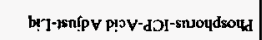 & $\mathrm{g}$ & & ¿zco001.S6S \\
\hline $\mathbf{e} p$ & +8 & $\omega$ & 956 & $10+3 \varepsilon 62$ & $6.2 z$ & $\llcorner .0 \varepsilon$ & $\mathfrak{E} 0-700^{\circ} C^{\circ}$ & +96 & $\mathrm{~T}^{\mathrm{m} / \mathrm{sn}}$ & 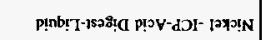 & $\mathrm{a}$ & & ₹zع0001.56s \\
\hline $\mathbf{x} \mathbf{u}$ & $z t$ & $\pi \mu$ & $6<0$ & so+ 9921 & 000921 & sotalz 1 & $\varepsilon 0$-ฮ00 $\varepsilon^{-}$ & 166 & $\mathrm{~T}^{\mathrm{m} / \mathrm{an}}$ & 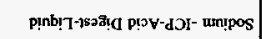 & g & & $\varepsilon z \varepsilon 000 L$ LS6S \\
\hline $1+x+2+20$ & 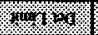 & \% & Solow & 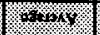 & oxwatho & insis & 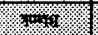 & $x_{r}=\mathrm{r}=\mathrm{x}$ & in & (2.) & No & 0. & widats \\
\hline
\end{tabular}


Table A-1. Laboratory Data Results for Tank 241-SY-103, Core 62!.

\begin{tabular}{|c|c|c|c|c|c|c|c|c|c|c|c|c|c|}
\hline S-mplo & 8 & 1 & $x_{10}$ & 19.12.1. & 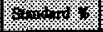 & (1) & 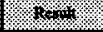 & Bown & 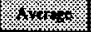 & sus & $x_{404}$ & by & 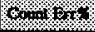 \\
\hline S94T000005 & & $\mathbf{F}$ & Calcium -ICP-Fusion & $\log / \mathrm{s}$ & 101.4 & $2.97 \mathrm{E}-01$ & $<4.52 e+02$ & 177 & $\mathbf{d} / \mathbf{a}$ & $\mathbf{n} / *$ & $\mathrm{n} / \mathrm{n}$ & 452 & $D^{\prime} / \boldsymbol{n}$ \\
\hline$\$ 94 \mathrm{~T} 000005$ & e & $\mathbf{F}$ & Chromium -ICP-Fusion & ugig & 102.2 & $6.00 \mathrm{E}-03$ & 64.5 & 54.2 & $5.94 \mathrm{E}+01$ & 17.4 & $n / a$ & 45.2 & $n / a$ \\
\hline S44T000005 & & $\mathbf{F}$ & Iron -ICP-Fusion & ug/g & 101.2 & $3.02 \mathrm{E}-01$ & $<2.26 x+02$ & 30.2 & $\mathrm{D} / \mathrm{a}$ & $\mathbf{w} / \mathbf{x}$ & $n / a$ & 226 & $\mathrm{n} / \mathbf{2}$ \\
\hline S94T00000s & & $\mathbf{F}$ & Potassium -ICP-Fusion (2) & $\operatorname{ug} / \mathrm{g}$ & 96.6 & $-1.40 \mathrm{E}-02$ & $\mathbf{n} / \mathbf{n}$ & $n / \mathbf{a}$ & $\boldsymbol{n} / \mathbf{n}$ & $n / \bullet$ & $\mathbf{n} / \mathbf{a}$ & $1.36 \mathrm{E}+03$ & $\pi / a$ \\
\hline S94T000005 & & $\mathbf{F}$ & Sodium -ICP-Fusion & ug/g & 97.4 & 3.88 & $1.41 \mathrm{E}+05$ & 141000 & $1.41 E+05$ & 0 & $n / 4$ & 452 & $n / a$ \\
\hline s94T000005 & & $\mathbf{F}$ & Nickel -ICP-Fusion (2) & ug/g & 101.8 & 6.66 & $a / a$ & $\mathrm{n} / \mathrm{m}$ & $\mathfrak{n} / \mathfrak{n}$ & $\mathrm{n} / \mathbf{a}$ & $n / n$ & 90.5 & $\mathrm{D} / \mathrm{a}$ \\
\hline S94T0000OS & & $\mathbf{F}$ & Zinc-ICP-Fusion & ug/g & 103.6 & $1.50 \mathrm{E}-02$ & $<\quad 45.20$ & 4.28 & $n / 2$ & $\mathrm{a} / \mathrm{a}$ & o/a & 45.2 & $n / \mathbf{a}$ \\
\hline s94T00000s & & F & Zirconium -ICP-Fusion & $\operatorname{ug} / g$ & 99.8 & $1.00 \mathrm{E}-01$ & $<\quad 45.20$ & -2.59 & $n / a$ & $\mathrm{n} / \mathrm{n}$ & $\mathrm{n} / \mathbf{a}$ & 45.2 & $\mathbf{n} / \mathbf{a}$ \\
\hline S94T000005 & 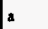 & $\mathbf{F}$ & Lithium -ICP-Fusion & ug/g & 98 & $<1.000 \mathrm{k}-2$ & LDL & LDL & $\mathrm{n} / \mathrm{a}$ & $D / 4$ & $n / 2$ & 95.1 & $n / a$ \\
\hline s94 T000005 & c & $\mathbf{F}$ & Np237 by TTA Extraction & uCi/g & 73.28 & $<9.320 e-3$ & $<1.17 e-02$ & $<9.29 e-3$ & $\mathrm{n} / \mathbf{2}$ & $n / 2$ & 63.7 & $2.00 \mathrm{E}-02$ & 490.6 \\
\hline s94T000005 & & $\mathbf{F}$ & Pu-238 by Iot Exchange & $\mathrm{uCi}_{\mathbf{L}} / \mathbf{g}$ & $n / \mathbf{a}$ & $1.00 \mathrm{E}-02$ & $<4.23 \mathrm{e}-03$ & $<3.67 e-3$ & $n / 2$ & $n / \mathbf{a}$ & $n / 4$ & $4.00 \mathrm{E}-03$ & 12.5 \\
\hline S94T00000S & & F & Pu-239/240 by TRU-SPEC Resin & $u C i / g$ & 97.89 & $<9.050<-3$ & $<4.23 e-03$ & $<3.67 e-3$ & $a / 2$ & $n / s$ & $n / 2$ & $4.00 \mathrm{E}-03$ & 13.2 \\
\hline S94T00000s & & $\mathbf{F}$ & Strontium-89/90 High Level & $\mathrm{uCi} / \mathrm{g}$ & 99.11 & $2.90 \mathrm{E}-92$ & 1.68 & 1.94 & $1.81 \mathrm{E}+\infty 0$ & 14.4 & $n / a$ & $1.00 \mathrm{E}-03$ & 1 \\
\hline 594 T000005 & & $\mathbf{F}$ & Technetium-99 Liq. Scint. & $\mathrm{uCi} / \mathrm{g}$ & 85.06 & $<2.480 \mathrm{k}-2$ & $1.91 \mathrm{E}-01$ & 0.175 & $1.83 \mathrm{E}-01$ & 8.74 & 85 & $2.50 \mathrm{E}-02$ & 4.14 \\
\hline s94T000006 & & & Bulk Deasity of Sample & $\mathrm{g} / \mathrm{mL}$ & whe & $\mathbf{n} / \mathbf{n}$ & 1.59 & $n / \mathbf{a}$ & $n / n$ & $n / m$ & $w$ & 5.00E-01 & $n / \mathbf{a}$ \\
\hline S94T000265 & & & pH on SST Semples & pH & 100.2 & $n / \mathbf{a}$ & 13.01 & 13.04 & $1.30 \mathrm{E}+01$ & 0.23 & $n / n$ & $1.00 \mathrm{E}-02$ & $a / a$ \\
\hline s94T000265 & & & TOC by Persulfate/Coulometry & ug/g & 90.67 & 32.5 & $4.92 \mathrm{E}+03$ & 4620 & 4. $7 \mathrm{E}+03$ & 6.29 & $n / a$ & 80 & $n / \mathbf{a}$ \\
\hline s94 T0000265 & & & TIC by Acid/Coulometry & ug/g & 97.83 & 2.200 & $2.68 e+03$ & $2.68 e+03$ & $2.68 e+03$ & 0.00 & $a / a$ & 5.000 & $n / \mathbf{a}$ \\
\hline S94T000266 & & A & Aluminium -ICP-Acid Digest & $\operatorname{ug} / \mathrm{g}$ & 97.6 & $2.60 \mathrm{E}-02$ & $2.89 \mathrm{E}+04$ & 29400 & $2.92 \mathrm{E}+04$ & 1.72 & $\mathrm{n} / \mathrm{a}$ & 17.6 & $\mathbf{w} / \mathbf{a}$ \\
\hline
\end{tabular}




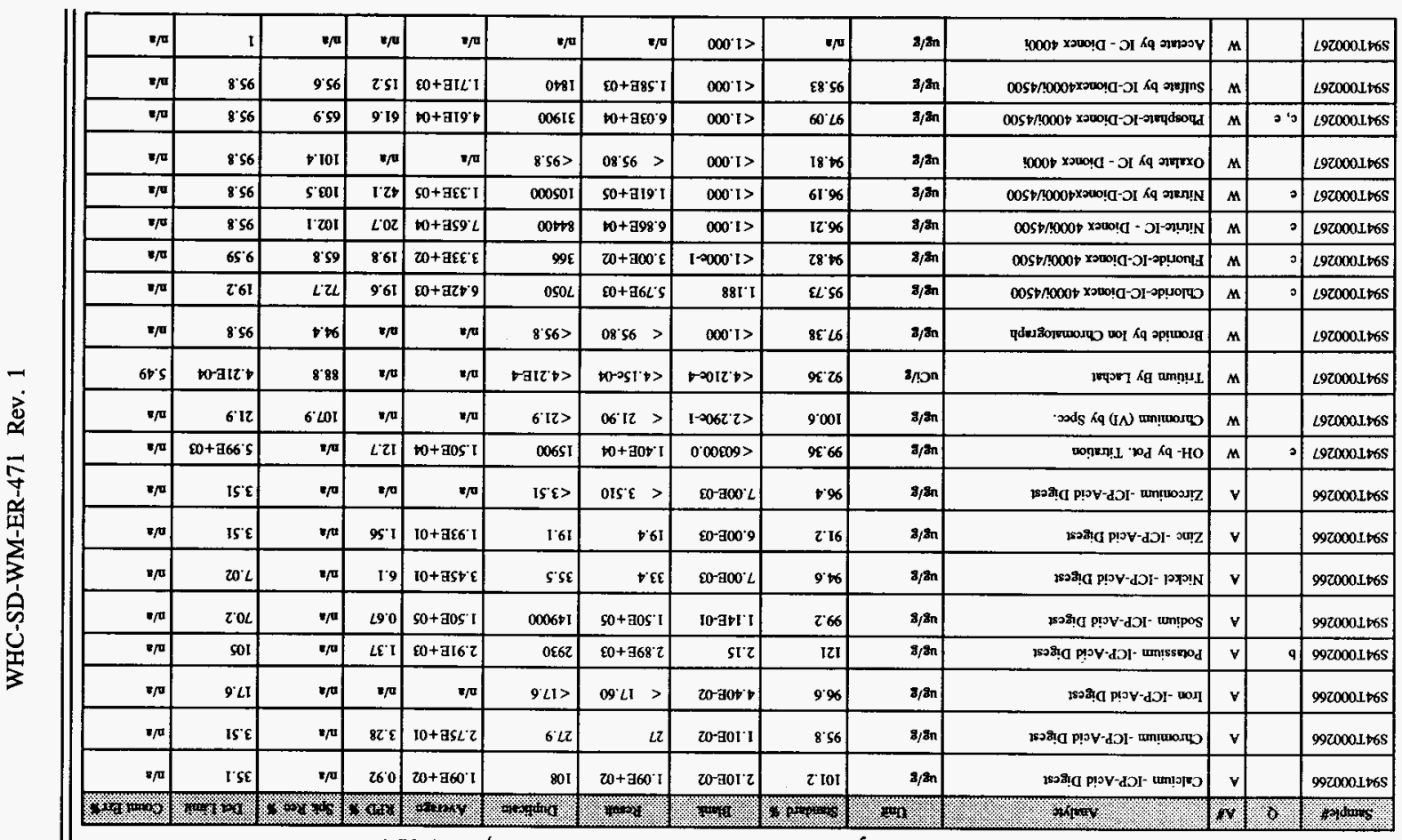

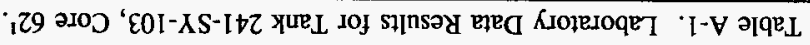


Table A-1. Laboratory Data Results for Tank 241-SY-103, Core 621.

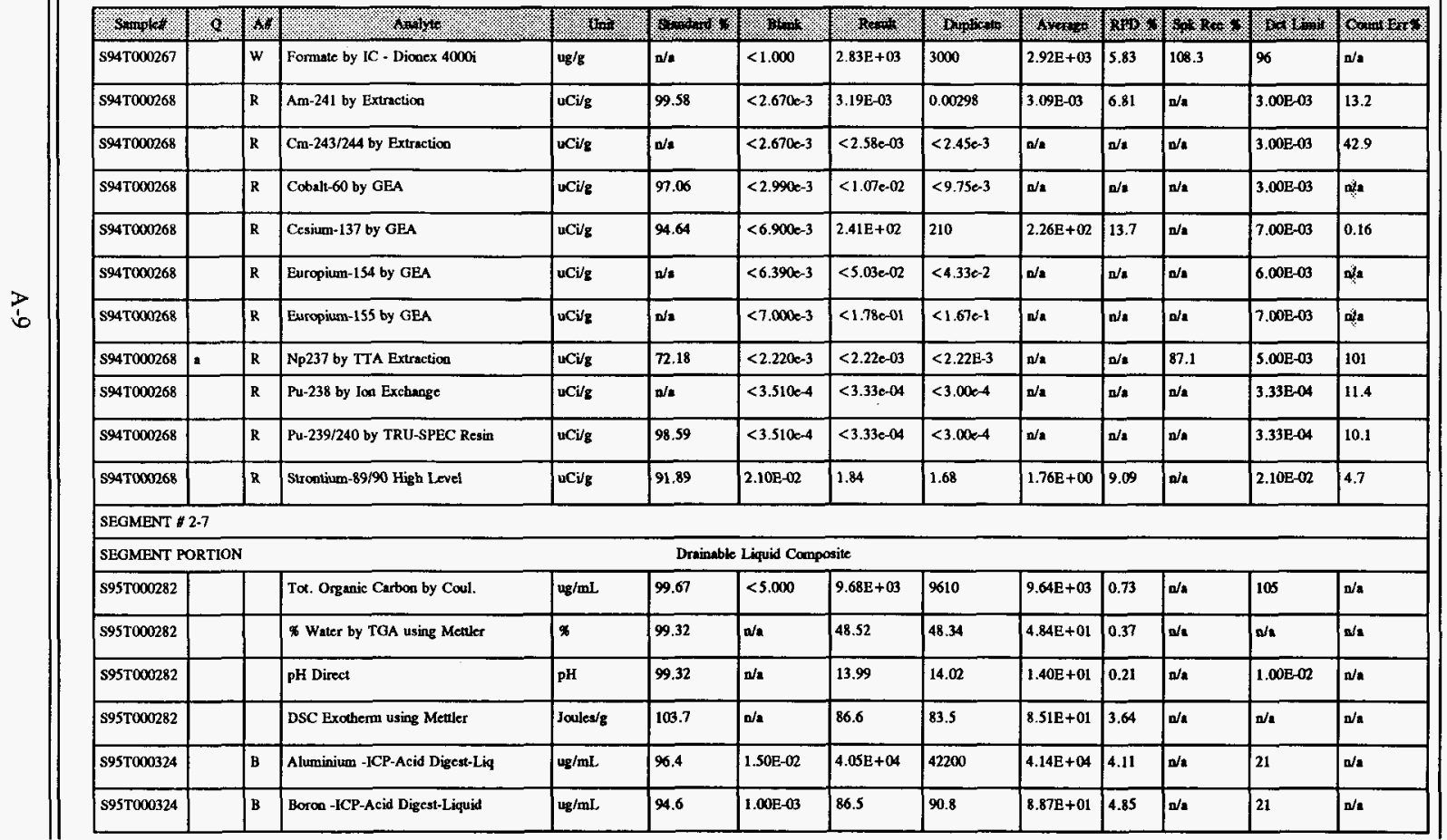


Table A-1. Laboratory Data Results for Tank 241-SY-103, Core $62^{1}$.

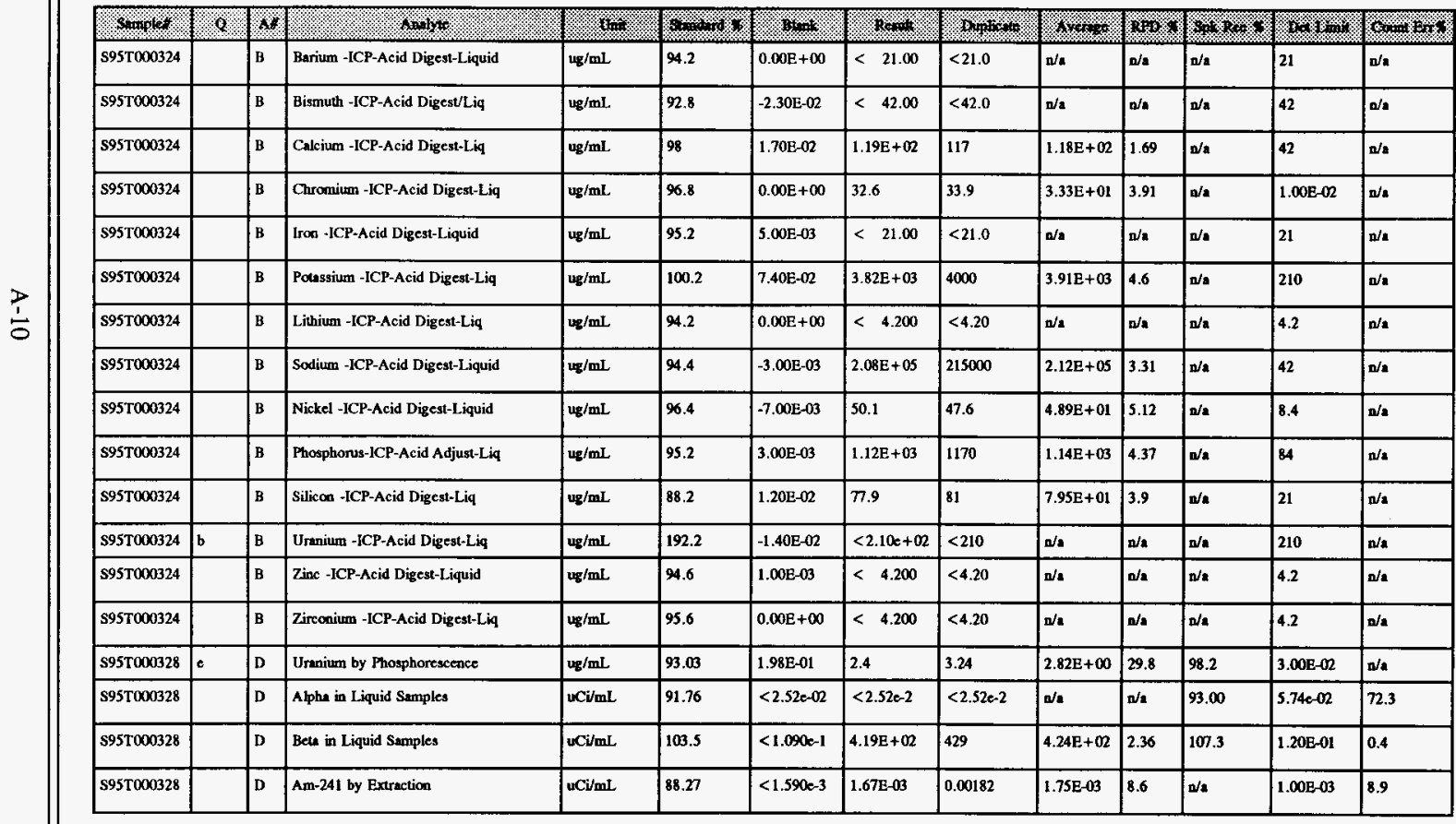


Table A-1. Laboratory Data Results for Tank 241-SY-103, Core 621.

\begin{tabular}{|c|c|c|c|c|c|c|c|c|c|c|c|c|c|}
\hline singule & 8 & win & 1.1.5. & 10 & (2) & Min & 8 & 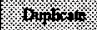 & 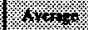 & Nor 8 & 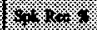 & $(x+1)=$ & Fin \\
\hline S95T000328 & & $D$ & Cm-243/244 by Extraction & $u C \mathrm{C} / \mathrm{mL}$ & $\mathrm{n} / \mathbf{a}$ & $<1.5900-3$ & $<7.790-04$ & $<1.04 c-3$ & $w / n$ & $\mathbf{n} / \mathbf{a}$ & $\mathrm{a} / \mathbf{a}$ & $1.00 \mathrm{E}-03$ & 29.8 \\
\hline S95T000328 & & D & Cotalt -60 by GEA & $\mathrm{uCi} / \mathrm{mL}$ & 104 & $<5.320 e-4$ & $<1.95 e-02$ & $<1.69 \mathrm{e}-2$ & a/s & $\mathbf{w} / \mathbf{a}$ & $\mathrm{a} / \mathbf{a}$ & $1.00 \mathrm{E}-03$ & $\ln _{2}$ \\
\hline S95T000328 & & D & Cesium- 137 by GEA & $\mathrm{uCi} / \mathrm{mL}$ & 100 & $<8.020 \mathrm{e}-4$ & $4.24 \mathrm{E}+02$ & 422 & $4.23 E+02$ & 0.47 & $\mathbf{a} / \mathbf{a}$ & $1.00 \mathrm{E}-03$ & 0.15 \\
\hline S95T000328 & & D & Europium-154 by GEA & uCi/nL & $\mathbf{a} / \mathbf{2}$ & $<1.330 \mathrm{c}-3$ & $<8.02=-02$ & $<8.28 \mathrm{e}-2$ & $\mathbf{n} / \mathbf{a}$ & $n / \mathbf{a}$ & $\mathbf{n} / \mathbf{n}$ & $1.00 \mathrm{E}-03$ & 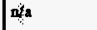 \\
\hline S95T000328 & & D & Europium- 155 by GEA & $u C \mathrm{Ci} / \mathrm{mL}$ & $a / a$ & $<1.180 x-3$ & $<2.58 \mathrm{e}-01$ & $<2.58 \mathrm{e}-1$ & $\mathbf{n} / \mathbf{2}$ & $\mathbf{n} / \mathbf{a}$ & $\mathrm{n} / \mathbf{a}$ & $1.00 E-03$ & $m_{\xi}^{\prime a n}$ \\
\hline S95T000328 & c & D & Tritium By Lachat & uCi/mL & 100 & $<6.950 k-5$ & $2.42 \mathrm{E}-03$ & 0.00226 & $2.34 \mathrm{E}-03$ & 6.84 & 73 & $6.95 \mathrm{E}-05$ & 2.32 \\
\hline s95T000328 & & D & Np237 by TTA Extraction & $\mathrm{uCi} / \mathrm{mL}$ & 82.92 & $<4.120 \mathrm{e}-4$ & $<8.34 \mathrm{e}-04$ & $<5.93 \mathrm{ec} 4$ & $n / 2$ & $\mathbf{a} / \mathbf{a}$ & 85.5 & $1.00 \mathrm{E}-18$ & 126.8 \\
\hline S95T000328 & & D & Pu-238 by Ion Exchange & $\mathrm{uCl} / \mathrm{mL}$ & $n / 2$ & $<5.900 \mathrm{e}-5$ & $<6.122-05$ & $<6.32 c-5$ & $n / a$ & $\mathrm{n} / \mathbf{2}$ & $\mathbf{n} / \mathbf{n}$ & $6.12 \mathrm{E}-05$ & 100 \\
\hline S95T000328 & & D & Pu-239/240 by TRU-SPEC Resin & uCi/mL & 93.75 & $<5.900 k-5$ & $<6.12 \mathrm{e}-05$ & $\mid<6.32 \mathrm{e}-5$ & $\mathbf{n} / \mathbf{2}$ & $\mathbf{n} / \mathbf{L}$ & $\mathbf{n} / \mathbf{2}$ & $6.12 \mathrm{E}-05$ & 3.1 \\
\hline S95T000328 & & D & Strontium-89/90 High Level & uCi/mL & 94.55 & $<9.580 \mathrm{R}-2$ & 2.91 & 3.06 & $2.99 \mathrm{E}+\infty$ & 5.03 & $\mathrm{n} / \mathbf{a}$ & $9.80 \mathrm{E}-02$ & 6 \\
\hline S95T000328 & & D & | Technetium-99 Liq. Scint. & uCi/mL & 96.68 & $1.00 \mathrm{E}-03$ & $1.54 E-01$ & 0.171 & $1.63 \mathrm{E}-01$ & 10.5 & $a / 2$ & $1.00 \mathrm{E}-03$ & 0.99 \\
\hline s95T000332 & & $\mathrm{v}$ & OH-by Pot. Titration & $\mathrm{ug} / \mathrm{mL}$ & 99.38 & $<4167.0$ & $2.93 \mathrm{E}+04$ & 27900 & $2.86 \mathrm{E}+04$ & 4.9 & $\mathbf{w} / \mathbf{n}$ & $4.17 \mathrm{E}+03$ & $\mathbf{a} / \mathbf{a}$ \\
\hline S95T000332 & e & $\mathrm{v}$ & Chromium (VI) by Spec. & ug/mL & 102.2 & $<3.900=-2$ & 6.76 & 5.35 & $6.06 \mathrm{E}+\infty 0$ & 23.3 & 105.4 & 3.939 & $\mathbf{n} / \mathbf{a}$ \\
\hline S95T000332 & & $\mathrm{v}$ & Iodine-129 Waste Tank Sarnples & $\mathrm{uCi} / \mathrm{mL}$ & 81.65 & $<5.910<-4$ & $<4.78 \mathrm{e}-04$ & 0.000191 & $n / 2$ & n/a & $\mathbf{n} / \mathbf{n}$ & $4.78 \mathrm{E}-04$ & $\mathrm{n} / \mathrm{a}$ \\
\hline S95T000332 & & v & Aromink by Ion Chromatograph & $\operatorname{ug} / \mathrm{mL}$ & 100 & $<40.80$ & $<4.08 e+03$ & $<4.08 \mathrm{e} 3$ & $n / a$ & $\mathbf{n} / \mathbf{u}$ & 94.3 & $4.08 \mathrm{E}+03$ & $\mathbf{n} / \mathbf{s}$ \\
\hline \$95T000332 & & $v$ & Cbloride-IC-Dioner $4000 \mathrm{i} / 4500$ & $\lg / \mathrm{mL}$ & 101.9 & $<5.100$ & $1.17 \mathrm{E}+04$ & 11500 & $1.16 \mathrm{E}+04$ & 1.72 & 112 & 510 & $\mathbf{n} / \mathbf{a}$ \\
\hline S95T000332 & & $\mathrm{v}$ & Fluoride-IC-Dionex 4000i/4500 & $\mathrm{ug} / \mathrm{mL}$ & 96.79 & $<3.060$ & $<3.06 e+02$ & $<3.06<2$ & $\mathrm{n} / \mathbf{a}$ & n/t & 81.8 & 306 & $\mathrm{n} / \mathrm{a}$ \\
\hline S95T000332 & & $\mathrm{v}$ & Nitrite-IC - Dionex 4000 i/4500 & $\mathrm{ug} / \mathrm{mL}$ & 93.51 & $<40.80$ & $1.45 \mathrm{E}+05$ & 141000 & $1.43 \mathrm{E}+05$ & 2.8 & 98.3 & $4.08 \mathrm{E}+03$ & $\mathrm{a} / \mathrm{a}$ \\
\hline
\end{tabular}


Table A-1. Laboratory Data Results for Tank 241-SY-103, Core 621.

\begin{tabular}{|c|c|c|c|c|c|c|c|c|c|c|c|c|c|}
\hline S & o & 4) & $x_{1}$ & (1). & 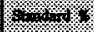 & $4 \%$ & $\mathrm{~d}^{4}$ & on & 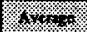 & $4+2$ & xhy & (Y) & $6 \% 10 \%$ \\
\hline s95T000332 & & v & Nitrate-IC - Dionex 4000i/4500 & $\mathrm{ug} / \mathrm{mL}$ & 102.2 & $<51.00$ & $1.83 \mathrm{E}+05$ & 175000 & $1.79 \mathrm{E}+05$ & 4.47 & 108 & $5.10 \mathrm{E}+03$ & $n / \mathbf{a}$ \\
\hline s95T000332. & & $\mathrm{v}$ & Oxaiate by IC - Dionex $4000 \mathrm{i}$ & $\mathbf{u g} / \mathrm{mL}$ & 91.68 & $<25.50$ & $<2.55 \mathrm{e}+03$ & $<2.55 \mathrm{e} 3$ & $n / \mathbf{a}$ & $\pi / \mathbf{a}$ & 93.2 & $2.55 \mathrm{E}+03$ & $n / a$ \\
\hline s95T000332 & & v & Phosphate-IC-Dionex $4000 \mathrm{i} / 4500$ & $\mathbf{u g} / \mathrm{mL}$ & 96.32 & $<30.60$ & $3.23 \mathrm{E}+03$ & 3020 & $3.12 \mathrm{E}+03$ & 6.72 & 96.7 & $3.06 \mathrm{E}+03$ & $\mathfrak{n} / \mathbf{a}$ \\
\hline S9ST000332 & & v & Sulfate by IC-Dionex $4000 \mathrm{i} / \mathbf{4 5 0 0}$ & $\operatorname{ug} / \mathrm{mL}$ & 101.7 & $<40,80$ & $<4.08 \varepsilon+03$ & $<4.08 \mathrm{e} 3$ & $\mathbf{n} / \mathbf{2}$ & $n / a$ & 99.9 & $4.08 E+03$ & $n / 2$ \\
\hline S95T000332 & & v & Acetale by IC - Dionex $4000 \mathrm{i}$ & $\mathrm{ug} / \mathrm{mL}$ & $n / a$ & $<2.000 \mathrm{e}-1$ & $1.37 \mathrm{E}+03$ & 1330 & $1.35 \mathrm{E}+03$ & 2.96 & 41.2 & 220 & $\mathrm{a} / \mathrm{a}$ \\
\hline \$95T000332 & & $v$ & Formate by Ion Chromatograph & $\mathrm{ug} / \mathrm{mL}$ & $n / a$ & $<2.000 \mathrm{c}-1$ & $4.28 \mathrm{E}+03$ & 4210 & $4.24 \mathrm{E}+03$ & 1.65 & 13.9 & 220 & $\mathbf{n} / \mathbf{a}$ \\
\hline \$95T000740 & & & Bulk Density of Sample & $\mathrm{g} / \mathrm{mL}$ & n/a & $n / \mathbf{a}$ & 1.47 & $n / 2$ & $n / \mathbf{a}$ & $0 / \mathbf{a}$ & $\mathrm{n} / \mathbf{a}$ & $5.00 E-01$ & $n / \mathbf{s}$ \\
\hline
\end{tabular}

SEGMENT \# 4-8

SEGMENT PORTION

Stratum "B" Solids Composite

\begin{tabular}{|c|c|c|c|c|c|c|c|c|c|c|c|c|c|}
\hline $594 \mathrm{~T} 000273$ & & & * Water by TGA on Perkin Elmer & * & 98.28 & $n / \mathbf{n}$ & 46.81 & 46.55 & $4.67 \mathrm{E}+01$ & 0.56 & $n / a$ & $n / \mathbf{a}$ & $n / a$ \\
\hline $594 \mathrm{~T} 000273$ & & & pH on SST Samples & pH & 100.2 & $n / a$ & 12.85 & 12.92 & $1.29 \mathrm{E}+01$ & 0.54 & $n / 2$ & $1.00 \mathrm{E}-02$ & $\mathbf{n} / \mathbf{a}$ \\
\hline 5947000273 & & & DSC Exotherm using Mettler & Joules/g & 100.2 & $\mathbf{n} / \mathbf{2}$ & $1.70 \mathrm{E}+02$ & 167.1 & $1.69 \mathrm{E}+02$ & 1.9 & $\mathbf{n} / \mathbf{a}$ & $\mathrm{n} / \mathbf{a}$ & $\mathbf{n} / \mathbf{a}$ \\
\hline s94T000273 & & & TOC by Persulfiste/Coutometry & $48 / 8$ & 90.67 & 32.5 & $2.40 \mathrm{E}+03$ & 2910 & $2.66 \mathrm{E}+03$ & 19.2 & $\mathbf{n} / \mathbf{a}$ & 80 & $\mathbf{n} / \mathbf{a}$ \\
\hline s94T000273 & & & TIC by Acid/Coulometry & $u g / g$ & 97.83 & 2.200 & $2.00 k+03$ & $2.05 e+03$ & $2.02 e+03$ & 2.47 & $n / a$ & 5.000 & $n / a$ \\
\hline S94T000276 & & A & Aluminium -ICP-Acid Digest & $u g / 2$ & 97.6 & $2.60 \mathrm{E}-02$ & $2.75 \mathrm{E}+04$ & 27500 & $2.75 \mathrm{E}+04$ & 0 & $\mathbf{n} / \mathbf{a}$ & 9.67 & $n / \mathbf{a}$ \\
\hline \$96T000598 & $c, e$ & A & Aluminum-ICP-Acid Digest (4) & $\operatorname{ug} / \mathrm{g}$ & 96.00 & $1.11 \mathrm{E}-01$ & $1.81 \mathrm{E}+04$ & $1.39 \mathrm{E}+04$ & $1.60 \mathrm{E}+04$ & 26.2 & 32.24 & 28.2 & $n / \mathbf{a}$ \\
\hline S94T000276 & & $A$ & Calcium -ICP-Acid Digest & $u g / g$ & 101.2 & $2.10 \mathrm{E}-02$ & $2.02 \mathrm{E}+02$ & 187 & $1.95 \mathrm{E}+02$ & 7.71 & $\mathbf{n} / \mathbf{a}$ & 19.3 & $\mathrm{a} / \mathbf{a}$ \\
\hline S94T000276 & & $A$ & Chromium -ICP-Acid Digest & $\mathrm{ug} / \mathrm{g}$ & 95.8 & $1.10 \mathrm{E}-02$ & 31.1 & 31 & $3.11 \mathrm{E}+01$ & 0.32 & $n / \mathbf{a}$ & 1.93 & $n / \mathbf{n}$ \\
\hline s96T000598 & c & $A$ & Chromium - ICP - Acid Digest (4) & $\mathrm{ug} / \mathrm{g}$ & 94.40 & $<1.00=02$ & 68.6 & 99.2 & 63.9 & 14.7 & 20.16 & 5.64 & $n / \mathbf{n}$ \\
\hline
\end{tabular}




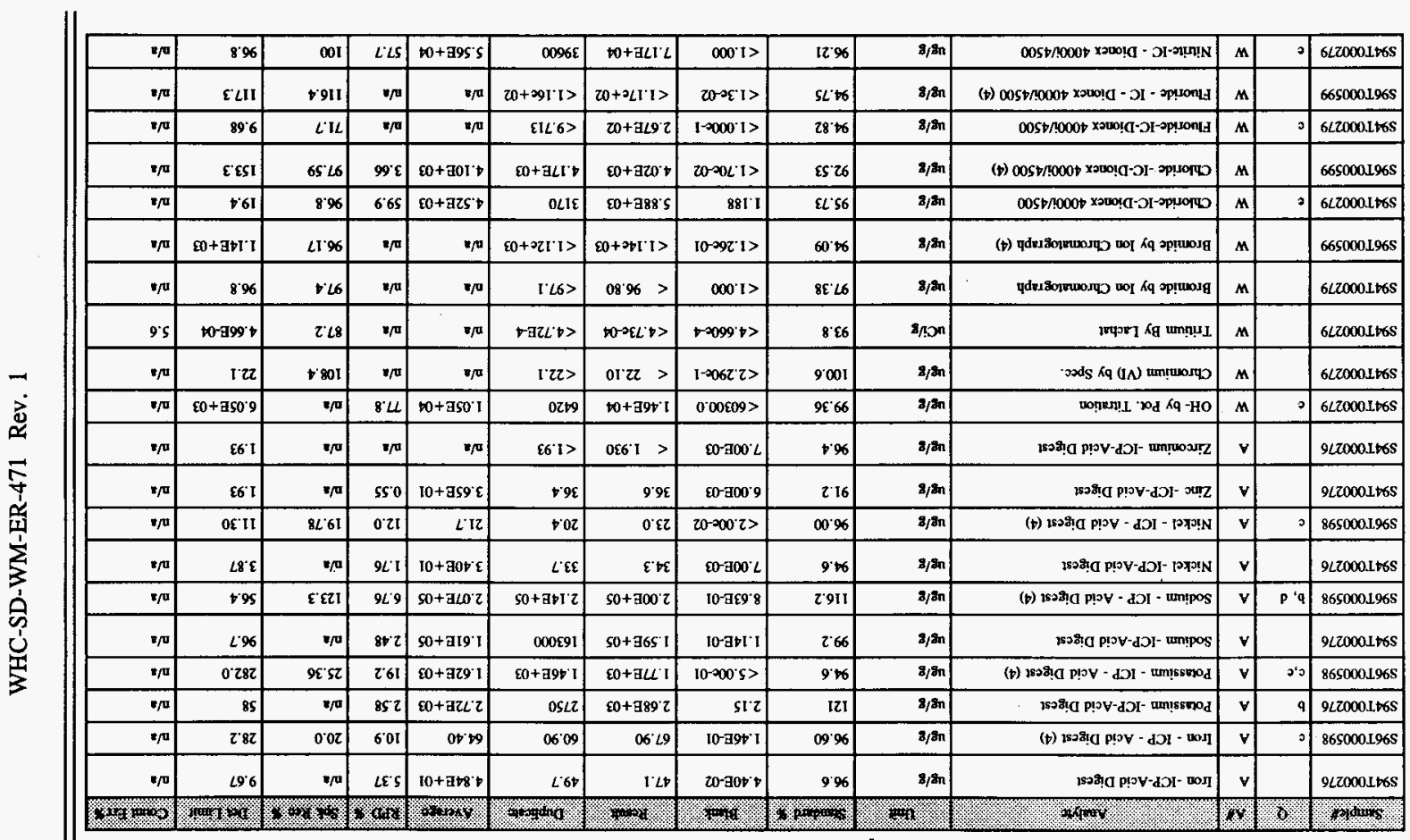

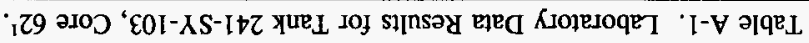


Table A-1. Laboratory Data Results for Tank 241-SY-103, Core $62^{1}$.

\begin{tabular}{|c|c|c|c|c|c|c|c|c|c|c|c|c|c|}
\hline Suming & 8 & \% & 2018 & 䊼 & 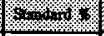 & 1010 & 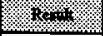 & \% & 30 & 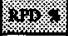 & 4 & (t) & 8. \\
\hline S96T000599 & & $w$ & Nitrite-IC - Dionex $4000 \mathrm{i} / 4500$ (4) & $\log / g$ & 90.88 & $<1.070-01$ & $4.71 E+04$ & $4.86 \mathrm{E}+04$ & $4.78 \mathrm{E}+04$ & 3.13 & 106.3 & 965.1 & $\mathrm{n} / \mathbf{2}$ \\
\hline S94T000279 & e & $w$ & Nitrate by IC-Dionex $4000 \mathrm{~J} / 4500$ & $\log / 8$ & 96.19 & $<1.000$ & $2.47 E+05$ & 465000 & $3.56 \mathrm{E}+0.5$ & 61.2 & 101.2 & 96.8 & $n / a$ \\
\hline \$96T000599 & & $w$ & Nitrate - IC - Dionex $4000 \mathrm{j} / 4500$ (4) & $\operatorname{ug} / \mathrm{s}$ & 94.95 & $2.34 \mathrm{E}-01$ & $4.13 E+05$ & $4.13 \mathrm{E}+05$ & 4.13E+05 & 0.00 & 112.5 & $1.26 \mathrm{E}+03$ & $\sqrt[N]{2}$ \\
\hline \$94T000279 & & $w$ & Oxalste by IC - Dionex $4000 \mathrm{i}$ & ug $/ g$ & 94.81 & $<1.000$ & $<96.80$ & $\langle 97.1$ & $\mathrm{n} / \mathbf{a}$ & $a / a$ & 101.4 & 96.8 & $\mathbf{n} / \mathbf{a}$ \\
\hline \$96T000599 & & $w$ & Oxalate by IC - Dionex 4000 i (4) & $\operatorname{ug} / \mathrm{g}$ & 96.63 & $<1.05 \mathrm{e}-01$ & $<9.47 e+02$ & $<9.63 \mathrm{E}+02$ & $n / a$ & $\Omega / a$ & 103.0 & 947.1 & $n / a$ \\
\hline s94T000279 & e & w & Phosphate-IC-Dionex $4000 \mathrm{~V} / 4500$ & u\&/g & 97.09 & $<1.000$ & $2.32 \mathrm{E}+04$ & 15400 & $1.93 \mathrm{E}+04$ & 40.4 & 97.5 & 96.8 & $\mathbf{n} / \mathbf{a}$ \\
\hline S96T000599 & & $w$ & Phosphate - IC - Dionex $4000 \mathrm{i} / 4500$ (4) & $\operatorname{og} / \mathrm{s}$ & 93.59 & $<1.19 \mathrm{E}-01$ & $2.40 \mathrm{E}+04$ & $2.43 E+04$ & $2.42 \mathrm{E}+04$ & 1.24 & 104.8 & $1.07 \mathrm{E}+03$ & $n / \mathbf{a}$ \\
\hline s94T000279 & e & w & Sulfate by IC-Dionex $4000 i / 4500$ & $\log / 8$ & 95.83 & $<1.000$ & $1.62 \mathrm{E}+03$ & 1090 & $1.36 \mathrm{E}+03$ & 39.1 & 94.2 & 96.8 & $n / \mathbf{a}$ \\
\hline S96T000599 & & $w$ & Sulfate - IC-Dionex 4000i/4500 (4) & $\mathrm{ug} / \mathrm{g}$ & 97.31 & $<1.360-01$ & $1.53 \mathrm{E}+03$ & $1.55 \mathrm{E}+03$ & $1.54 \mathrm{E}+03$ & 1.3 & 101.6 & $1.23 \mathrm{E}+03$ & $n / a$ \\
\hline \$94T000279 & & w & Acetale by $\mathrm{IC} \cdot$ Dionex $4000 \mathrm{i}$ & $\operatorname{ug} / \mathrm{g}$ & $\mathbf{n} / \mathbf{a}$ & $<1.000$ & $\mathrm{n} / \mathrm{a}$ & n/a & nin & $n / a$ & nia & 1 & D/a \\
\hline S94T000279 & & w & Formate by IC - Dionex $4000 \mathrm{i}$ & ug/g & $n / \mathbf{a}$ & $<1.000$ & $2.70 \mathrm{E}+03$ & 2800 & $2.75 \mathrm{E}+03$ & 3.64 & 91.7 & 96.8 & $n / \mathbf{a}$ \\
\hline \$96T000599 & & $w$ & Formalc by IC - Dionex 4000 i (4) & ug/g & 104.8 & $<2.00 k-01$ & $2.43 E+03$ & $2.33 \mathrm{E}+03$ & $2.38 \mathrm{E}+03$ & 4.2 & 113.6 & 483.8 & wa \\
\hline S94T000282 & & $R$ & Am-241 by Extraction & uCi/g & 99.58 & $<2.670 e-3$ & $<2.88 \mathrm{e}-03$ & $<2.50-3$ & $n / a$ & $n / m$ & $n / a$ & $3.00 \mathrm{E}-03$ & 14.2 \\
\hline $594 \mathrm{~T} 000282$ & & R & Cm-243/244 by Extraction & uCi/g & $n / \mathbf{a}$ & $<2.670 e-3$ & $<2.88 \mathrm{e}-03$ & $<2.500-3$ & $n / a$ & $0 / a$ & $n / a$ & $3.00 \mathrm{E}-03$ & 52.5 \\
\hline S94T000282 & & $\mathrm{R}$ & Cobalt- 60 by GEA & $\mathrm{uCi} / \mathrm{z}$ & 107.4 & $<2.910<-3$ & $<1.01 \in-02$ & 0.00626 & $\mathrm{D} / \mathrm{a}$ & w/a & $n / a$ & $3.00 \mathrm{E}-03$ & ALA \\
\hline s94T000282 & c & $\mathbf{R}$ & Cesium-137 by GEA & uCi/g & 103.1 & $<6.560 k-3$ & $2.21 E+02$ & 130 & $1.76 \mathrm{E}+02$ & 51.9 & $\mathrm{~d} / \mathrm{a}$ & $7.00 \mathrm{E}-03$ & 0.16 \\
\hline s94T000282 & & R & Europiurn-154 by GEA & $\cup \mathrm{Ci} / \mathrm{g}$ & $n / n$ & $<7.970 \mathrm{e}-3$ & $<4.72 \mathrm{e}-02$ & $<2.67 \mathrm{e}-2$ & $\mathbf{n} / \mathbf{a}$ & $n / 2$ & $n / a$ & $8.00 \mathrm{E}-03$ & MANi: \\
\hline S94T000282 & & $\mathbf{R}$ & Europiurn- 155 by GEA & $\mathbf{u C i} / \mathbf{z}$ & $n / n$ & $<6.960<-3$ & $<1.72 \mathrm{e}-01$ & $<1.32 \mathrm{e}-1$ & $\mathbf{n} / \mathbf{a}$ & $n / a$ & D/a & $7.00 \mathrm{E}-03$ & NASA \\
\hline $594 \mathrm{T000282}$ & c & $\mathbf{R}$ & Np237 by TTA Extraction & |uCi/g & 80.17 & $<2.420 e-3$ & $<2.42 \mathrm{e}-\mathrm{BB}$ & $<2.516-3$ & $n / a$ & $n / \mathbf{n}$ & 72.6 & $5.00 \mathrm{E}-03$ & 109.9 \\
\hline
\end{tabular}


Table A-1. Laboratory Data Results for Tank 241-SY-103, Core $62^{1}$.

\begin{tabular}{|c|c|c|c|c|c|c|c|c|c|c|c|c|c|}
\hline s.nupot & 6. & 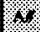 & $6 \sqrt{2}$ & 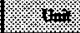 & 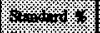 & 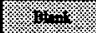 & $x$ & $(x)=4$ & 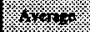 & (1) & 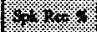 & Hor & 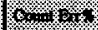 \\
\hline$\$ 94 T 000282$ & & $\mathbf{R}$ & Pu-238 by lon Exchange & uCi/g & $n / \mathbf{a}$ & $<3.510 c-4$ & $<3.136 .04$ & $<4.32 e-4$ & $\mathbf{n} / \mathbf{2}$ & $\mathbf{n} / \mathbf{a}$ & n/ı & $3.13 \mathrm{E}-04$ & 100 \\
\hline $594 T 000282$ & & R & Pu-239/240 by TRU-SPEC Resin & $\mathbf{u C i} \mathbf{k}$ & 98.59 & $<3.510 c-4$ & $<3.13 \mathrm{e}-04$ & $<4.32 c-4$ & $\mathbf{n} / \mathbf{m}$ & $n / a$ & $\mathbf{n} / \mathbf{a}$ & 3.13E-04 & 11.8 \\
\hline S94T000282 & e & $\mathbf{R}$ & Stroatium-89/90 High Level & uCi/g & 93.69 & $2.00 \mathrm{E}-03$ & 1.65 & 0.954 & $1.30 \mathrm{E}+00$ & 53.5 & $n / 2$ & $2.00 \mathrm{E}-03$ & 1.5 \\
\hline S94T000299 & & $\mathbf{F}$ & Urmium by Phosphorescence & ugg/g & 108.5 & $<2.120 k-2$ & $<2.12 \mathrm{e}-02$ & $<2.03 e-2$ & $\mathbf{a} / \mathbf{a}$ & $\mathbf{n} / \mathbf{a}$ & 107.3 & $2.10 \mathrm{E}-02$ & $\mathbf{n} / \mathbf{a}$ \\
\hline S94T000299 & & $\mathbf{F}$ & Alphs of Digested Solid & uci/g & 97.6 & $<3.270 \mathrm{k}-3$ & $<4.51 e-03$ & $<5.50 k-3$ & $\mathbf{n} / \mathbf{n}$ & $\mathbf{n} / \mathbf{n}$ & 87.8 & $8.00 \mathrm{E}-03$ & 500 \\
\hline S94T000299 & & $\mathbf{F}$ & Am-241 by Extraction & $\mathrm{uCi} / \mathrm{g}$ & 102.5 & $<5.7900-2$ & $<1.52 e-02$ & $<1.47 \mathrm{e}-2$ & $\mathbf{a} / \mathbf{a}$ & $\mathbf{n} / \mathbf{a}$ & $\mathbf{n} / \mathbf{a}$ & $1.50 \mathrm{E}-02$ & 19.2 \\
\hline$\$ 94 \mathrm{~T} 000299$ & & $\mathbf{F}$ & Cm-243/244 by Extraction & uCi/g & $\mathbf{n} / \mathbf{a}$ & $<5.7900-2$ & $<1.52 \mathrm{ean} 2$ & $<1.47 \odot-2$ & $\mathbf{a} / \mathbf{a}$ & $n / a$ & $n / \mathbf{n}$ & $1.50 \mathrm{E}-02$ & 113.2 \\
\hline $594 \mathrm{~T} 000299$ & & $\mathbf{F}$ & Bete of Solid Sample & uCi'g & 90.06 & $3.20 \mathrm{E}-01$ & $1.79 \mathrm{E}+02$ & 162 & $1.71 \mathrm{E}+02$ & 9.97 & 87.5 & $2.38 \mathrm{E}-01$ & 0.8 \\
\hline$\$ 94$ T000299 & & F & Cobalt-60 by GEA & uCi/g & 105.4 & $<2.0900-2$ & $<2.350-02$ & $<2.27 \mathrm{e}-2$ & $\mathrm{n} / \mathbf{a}$ & n/m & m/n & $2.10 \mathrm{E}-02$ & nian \\
\hline S94T000299 & & F & Cesium-137 by GEA & |uCi/g & 96.94 & $<3.970-2$ & $1.39 \mathrm{E}+02$ & 128 & $1.34 \mathrm{E}+02$ & 8.24 & $\mathbf{a} / \mathbf{a}$ & $4.00 \mathrm{E}-02$ & 0.49 \\
\hline 5947000299 & & F & Europium- 154 by GEA & uCi/g & $n / n$ & $<3.6300-2$ & $<5.980-02$ & $<6.02 e-2$ & $\mathrm{n} / \mathbf{a}$ & $n / 2$ & $n / n$ & $3.60 \mathrm{E}-02$ & 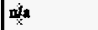 \\
\hline S94T000299 & & $\mathbf{F}$ & Europium-155 by GEA & |uCi/g & $\mathrm{n} / \mathrm{a}$ & $<4.580<-2$ & $<3.29-01$ & $<3.08 \mathrm{e}-1$ & $a / \mathbf{a}$ & $n / \mathbf{a}$ & $n / a$ & $4.60 \mathrm{E}-02$ & mate \\
\hline S94T000299 & & $\mathbf{F}$ & Lodine-129 Waste Tank Semples & |ucig & 107.9 & $<1.0400-1$ & $<1.68001$ & $<3.09 \mathrm{e}-1$ & $\mathrm{n} / \mathbf{a}$ & $n / a$ & $\mathbf{n} / \mathbf{a}$ & $1.68 \mathrm{E}-01$ & ma \\
\hline S94 T000299 & & F & Aluminium -ICP-Fusion & uge/g & 98.2 & $5.80 \mathrm{E}-01$ & $1.30 \mathrm{E}+04$ & 11900 & $1.24 \mathrm{E}+04$ & 8.84 & $\mathbf{n} / \mathbf{s}$ & 287 & $\mathbf{n} / \mathbf{a}$ \\
\hline $594 \mathrm{~T} 000299$ & & $F$ & Calcium -ICP-Fusion & $u g / g$ & 102 & $4.58 \mathrm{E}-01$ & $<5.73 e+02$ & $<548$ & $n / \mathbf{a}$ & n/a & $\mathrm{n} / \mathrm{a}$ & 3 & $\mathbf{n} / \mathbf{a}$ \\
\hline $594 \mathrm{~T} 000299$ & & $\mathrm{~F}$ & Iron -ICP-Fusion & ug/g & 101.2 & 3.42E-01 & $<2.87 e+02$ & $<274$ & $\mathbf{a} / \mathbf{a}$ & $\mathbf{a} / \mathbf{s}$ & $\mathbf{n} / \mathbf{m}$ & $1.00 \mathrm{E}-01$ & $\mathbf{a} / \mathbf{a}$ \\
\hline S94T000299 & & $F$ & Potussium -ICP-Fusion (2) & ug/g & 100 & $6.10 \mathrm{E}-02$ & $\mathbf{n} / \mathbf{a}$ & $\mathbf{n} / \mathbf{a}$ & $\mathbf{n} / \mathbf{a}$ & $\mathbf{n} / \mathbf{a}$ & $\mathbf{n} / \mathbf{2}$ & $5.00 \mathrm{E}-01$ & $\mathbf{n} / \mathbf{a}$ \\
\hline S94T000299 & & $\mathbf{F}$ & Sodium -ICP-Fusion & ug/g & 98 & 3.87 & $2.23 \mathrm{E}+05$ & 201000 & $2.12 \mathrm{E}+05$ & 10.4 & $\mathrm{a} / \mathbf{a}$ & 1 & $\mathbf{w} / \mathbf{t}$ \\
\hline
\end{tabular}


Table A-1. Laboratory Data Results for Tank 241-SY-103, Core 621.

\begin{tabular}{|c|c|c|c|c|c|c|c|c|c|c|c|c|c|}
\hline Sumpled & 8 & 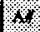 & 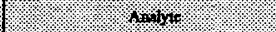 & y. & KN, & 10. & 4 & Wo. & 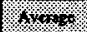 & B. 0.1 & 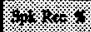 & $8, y+40$ & \%oln \\
\hline s94 T000299 & & $\mathbf{F}$ & Nickel -ICP-Fusion (2) & ug/g & 100.8 & 2.09 & a/a & $n / a$ & $n / a$ & 80.8 & $\mathrm{n} / \mathrm{a}$ & 2 & $n / 2$ \\
\hline$\$ 94 \mathrm{~T} 000299$ & & $\mathbf{F}$ & Zinc -ICP-Fusion & ug/g & 102.8 & $-2.20 \mathrm{E}-02$ & $<57.30$ & LDL & $a / a$ & $\mathbf{a} / \mathbf{a}$ & $n / a$ & 57.3 & $n / \mathbf{a}$ \\
\hline S94T000299 & & $\mathbf{F}$ & Zirconium -ICP-Fusion & ugg/g & 99.6 & $6.70 \mathrm{E}-02$ & $<57.30$ & LDL & $n / a$ & $\mathbf{n} / \mathbf{a}$ & $n / 4$ & 57.3 & $n / a$ \\
\hline$\$ 94 T 000299$ & & $\mathbf{F}$ & Np237 by TTA Extraction & $\mathrm{uCi} / \mathrm{g}$ & 81.27 & $<1.870 \mathrm{k}-2$ & $1.45 \mathrm{E}-02$ & $<2.40 k-2$ & $\mathrm{~b} / \mathrm{a}$ & $n / a$ & 83.2 & $2.50 \mathrm{E}-02$ & 102.5 \\
\hline$\$ 94 \mathrm{~T} 000299$ & & $\mathbf{F}$ & Pu-238 by Ion Exchange & uCi/g & $n / 2$ & $<2.900 \mathrm{e}-3$ & $<2.420-03$ & 0.00399 & $n / \mathbf{a}$ & $n / \mathbf{a}$ & $0 / 2$ & $2.00 \mathrm{E}-03$ & 10.9 \\
\hline s94T000299 & & $\mathbf{F}$ & Pu-239/240 by TRU-SPEC Resin & $\mathrm{uCi} / \mathrm{g}$ & 112.7 & $<2.900 \mathrm{k}-3$ & $<2.42 e-03$ & $<2.78 \mathrm{e}-3$ & $n / n$ & $\mathbf{n} / \mathbf{2}$ & $n / \mathbf{a}$ & $2.00 \mathrm{E}-03$ & 8.6 \\
\hline $594 \mathrm{~T} 000299$ & & $\mathbf{F}$ & Strontium-89/90 High Level & $\mathrm{uCi} / \mathrm{g}$ & 89.29 & $1.00 \mathrm{E}-03$ & 1.11 & 1.14 & $1.13 \mathrm{E}+\infty$ & 2.67 & $\sqrt{n}$ & $3.00 \mathrm{E}-03$ & 2.1 \\
\hline S95T000739 & & & Bulk Deasity of Sample & $\mathrm{g}^{\prime \mathrm{mL}}$ & $n / \mathbf{a}$ & $n / a$ & 1.51 & $\mathbf{n} / \mathbf{a}$ & $\mathbf{n} / \mathbf{a}$ & $n / 2$ & $n / a$ & $5.00 \mathrm{E}-01$ & $n / 2$ \\
\hline 5967001319 & & $\mathbf{I}$ & Aluminum - ICP - H2O Dig/Acid (4) & ug $/ g$ & 97.4 & $<5.00 \mathrm{E}-02$ & $1.40 \mathrm{E}+04$ & $1.45 \mathrm{E}+04$ & $1.42 \mathrm{E}+04$ & 3.51 & 81.70 & 22.6 & $n / \mathbf{a}$ \\
\hline \$96T001319 & e & I & Chromium - ICP - H2O Dig/Acid (4) & ug/g & 102.4 & $<1.00 \mathrm{e}-02$ & 10.6 & 12.5 & 11.55 & 16.5 & 103.2 & 4.52 & $n / \mathbf{a}$ \\
\hline$S 96 \mathrm{~T} 001319$ & & I & Iron - ICP - H2O Dig/Acid (4) & ug/g & 101.2 & $<5,00 \times-02$ & $<22.6$ & $<22.3$ & $\mathbf{n} / \mathbf{n}$ & $n / n$ & 102.0 & 22.6 & $n / n$ \\
\hline S96T001319 & & I & Potassium - ICP - H2O Dig/Acid (4) & $\operatorname{ug} / 8$ & 102.6 & $<5.00=-01$ & $1.46 \mathrm{E}+03$ & $1.63 \mathrm{E}+03$ & $1.54 \mathrm{E}+03$ & 11.0 & 108.5 & 226.0 & $n / \mathbf{a}$ \\
\hline$\$ 96 \mathrm{TC01319}$ & & I & Sodium - ICP - H2O Dig/Acid (4) & ug/g & 98.6 & 4.51 & $2.13 E+05$ & $2.14 \mathrm{E}+05$ & $2.14 \mathrm{E}+05$ & 0.47 & $n / a$ & 45.2 & $a / n$ \\
\hline S96T001319 & & I & Nickel - ICP - H2O Dig/Acid (4) & ug/g & 100.8 & $<2.00<-02$ & 18.8 & 19.8 & 19.3 & 5.18 & 100.4 & 9.04 & $\mathbf{a} / \mathbf{a}$ \\
\hline$\$ 95 T 001394$ & & F & Chromium -ICP-Fusion & $\operatorname{ug} / \mathrm{g}$ & 101.3 & $8.90 \mathrm{E}-02$ & $<95.35$ & $<93.1904$ & $\mathbf{n} / \mathbf{a}$ & $\mathbf{a} / \mathbf{a}$ & $n / 2$ & 95.3 & $\mathrm{n} / \mathbf{a}$ \\
\hline S957001394 & $e, f$ & $\mathbf{F}$ & Technetium-99 Liq. Scint. & $\mathrm{uCi} / \mathrm{g}$ & 104.1 & $3.60 \mathrm{E}-12$ & $1.26 \mathrm{E}-0 \mathrm{t}$ & 0.167 & $1.47 \mathrm{E}-01$ & 28 & $\mathbf{n} / \mathbf{a}$ & $3.10 \mathrm{E}-02$ & 5.45 \\
\hline
\end{tabular}


Table A-1. Laboratory Data Results for Tank 241-SY-103, Core 621.

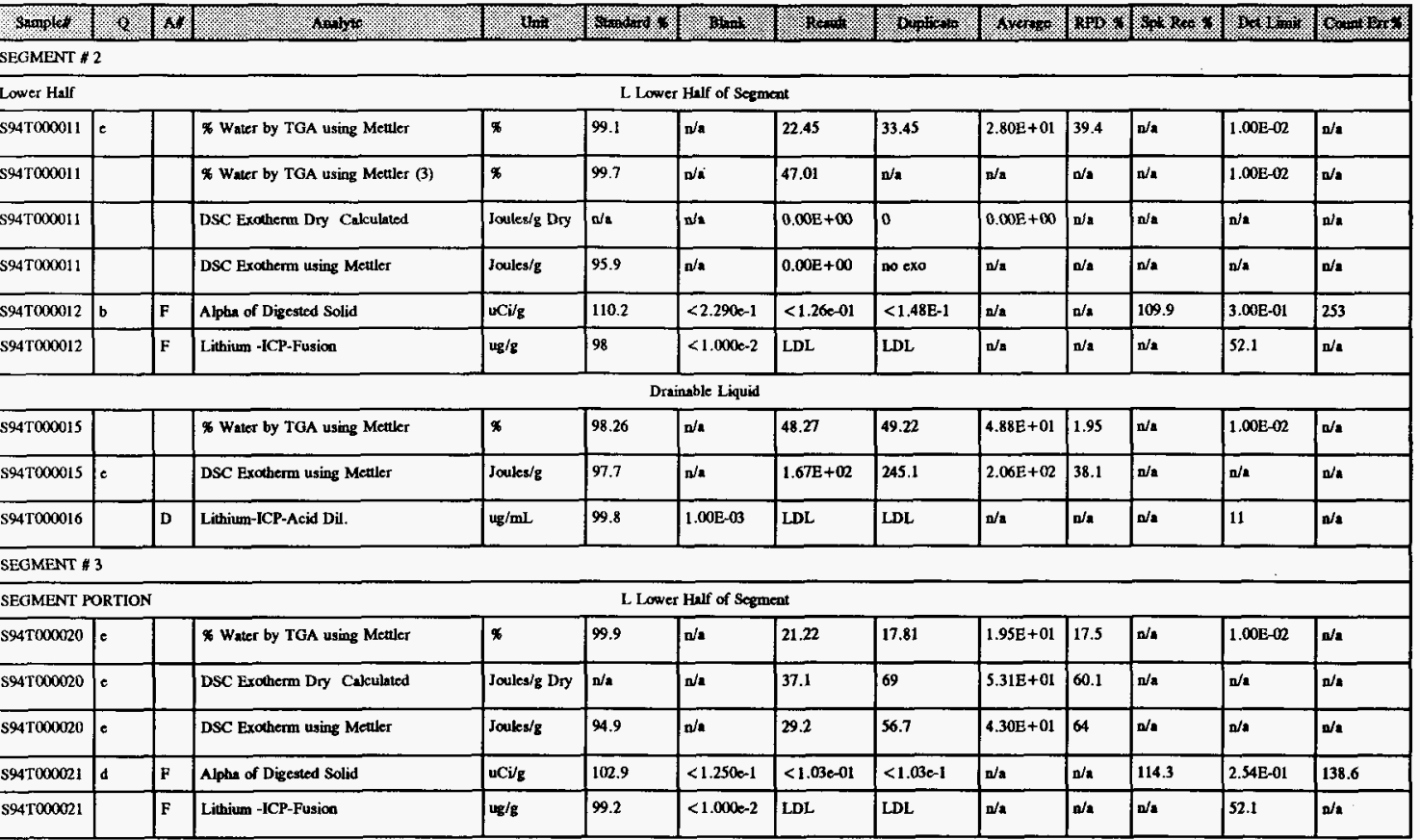




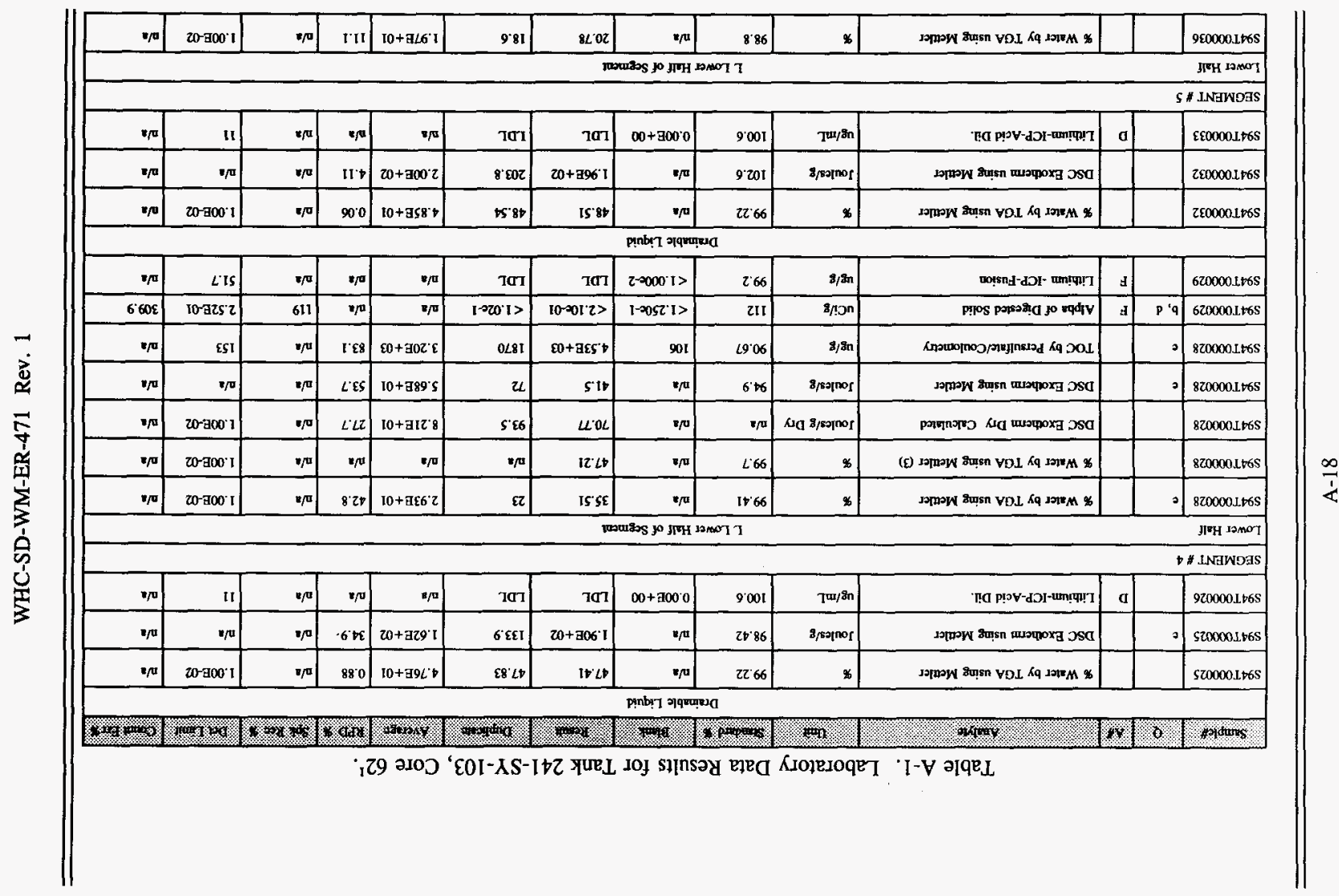


Table A-1. Laboratory Data Results for Tank 241-SY-103, Core 62!.

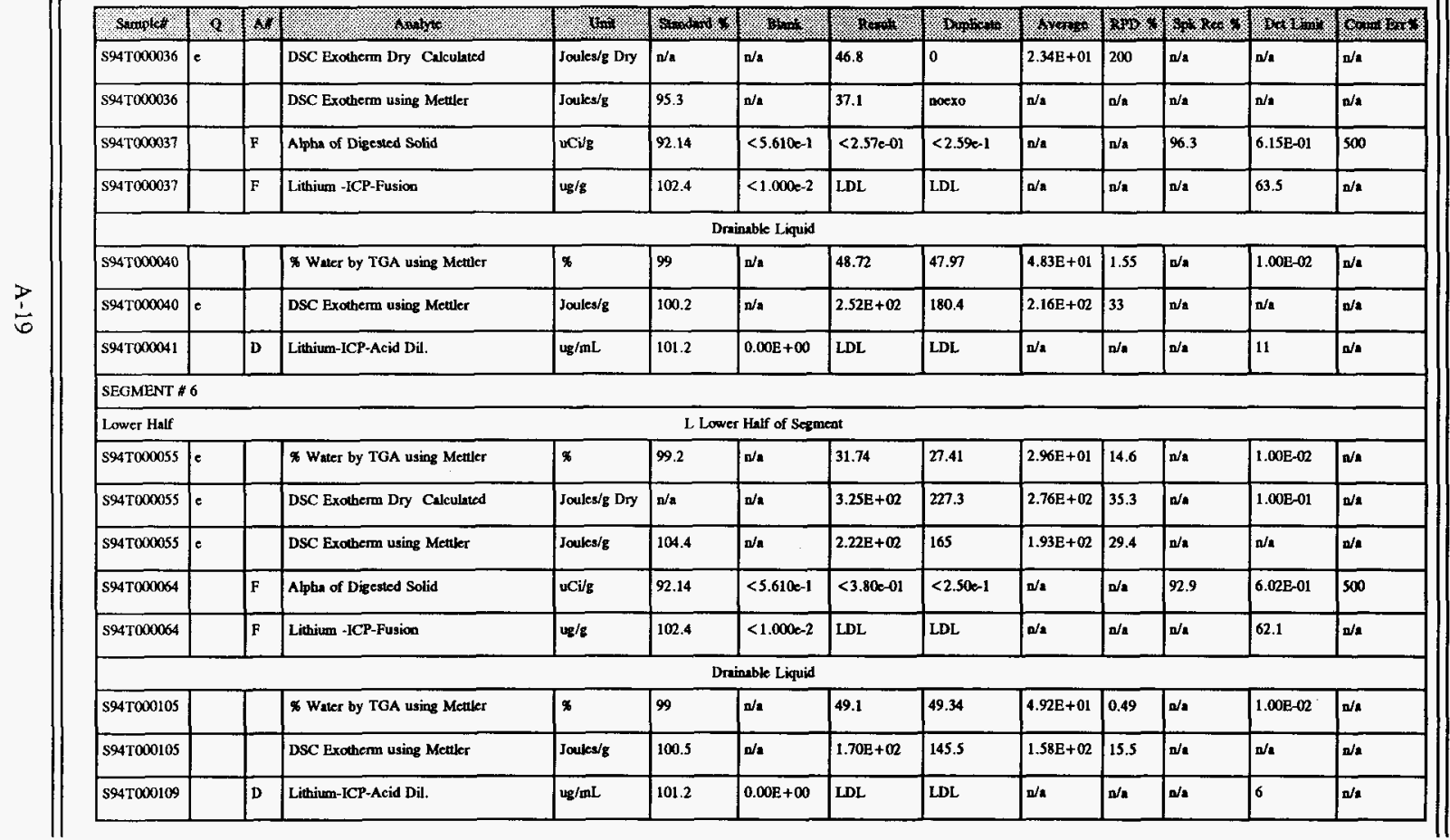


Table A-1. Laboratory Data Results for Tank 241-SY-103, Core 62'.

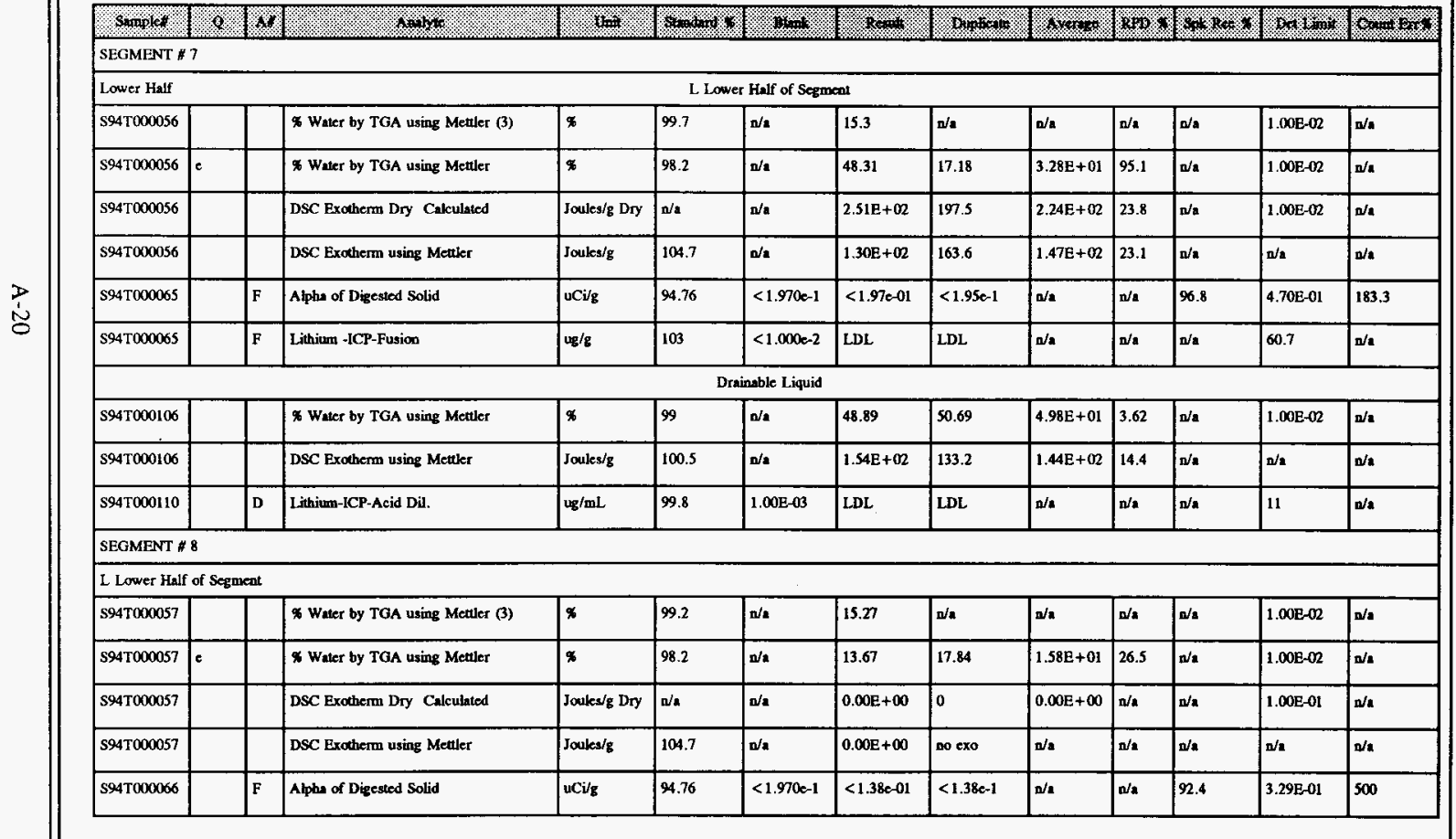


WHC-SD-WM-ER-471 Rev. 1

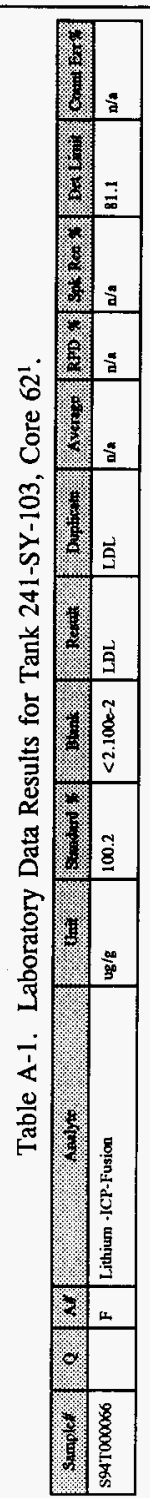


Table A-1. Laboratory Data Results for Tank 241-SY-103, Core 621.

\begin{tabular}{|c|c|c|c|c|c|c|c|c|c|c|c|c|c|}
\hline $9 \%$ & $\%$ & 1 & 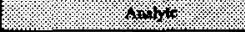 & 110 & K $14 \%$ & 110 & Kan & $10 \times 14$ & \% 14 & \% & W & $3 \%$ & 6.1. \\
\hline \multicolumn{14}{|c|}{ Drainable Liquid } \\
\hline s94T000107 & & & o Water by TGA using Mettler & $\%$ & 99 & $a / a$ & 49.03 & 48.75 & $4.89 \mathrm{E}+01$ & 0.57 & $n / n$ & $1.00 \mathrm{E}-02$ & $n / \mathbf{a}$ \\
\hline S94T000107 & & & DSC Exotherm using Mettler & Joules/g & 100.2 & $\mathbf{m} / \mathbf{a}$ & $2.14 \mathrm{E}+02$ & 239.2 & $2.27 \mathrm{E}+02$ & 11 & $n / a$ & $w^{\prime} / 2$ & $\mathbf{n} / \mathbf{a}$ \\
\hline S94T000111 & & D & Lithiurn-ICP-Acid Dil. & ug/mL & 99.8 & $1.00 \mathrm{E}-03$ & LDL & LDL & $n / 2$ & $n / \mathbf{a}$ & $n / \mathbf{a}$ & 11 & $n / 2$ \\
\hline S94T0000B2 & & & Bulk Deasity of Sample & $\mathrm{g} / \mathrm{mL}$ & $n / a$ & $\mathbf{n} / \mathbf{a}$ & 1.47 & $\mathbf{n} / \mathbf{a}$ & $n / \mathbf{a}$ & $\alpha /$ & $\mathbf{n} / \mathbf{a}$ & $5.00 \mathrm{E}-01$ & $n / \mathbf{n}$ \\
\hline S95T000283 & & & Ta. Organic Carbon by Coul. & $\operatorname{ug} / \mathrm{mL}$ & 99.67 & $<5.000$ & $1.01 E+04$ & 9980 & $1.00 \mathrm{E}+04$ & 1.2 & $n / a$ & 105 & $0 / a$ \\
\hline \$95T000283 & & & \% Water by TGA using Mettler & 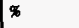 & 98.83 & $a / a$ & 47.65 & 47.85 & $4.78 \mathrm{E}+01$ & 0.42 & $n / \mathbf{a}$ & $w / a$ & $n / n$ \\
\hline s95T000283 & & & pH Direct & $\mathrm{pH}$ & 99.46 & $\mathbf{w} / \mathbf{a}$ & 13.9 & $\mathbf{n} / \mathbf{a}$ & $0 / 2$ & $n / x$ & $n / a$ & $1.00 \mathrm{E}-02$ & $n / a$ \\
\hline S95T000283 & & & DSC Exotherm using Mettler & Joules/g & $95 . \%$ & $\mathbf{w} / \mathbf{a}$ & 29.2 & 31.4 & $3.03 \mathrm{E}+01$ & 7.26 & $\mathrm{n} / \mathrm{a}$ & $n / a$ & $n / \mathbf{a}$ \\
\hline S95T000325 & & B & Aluminium -ICP-Acid Digest-Liq & $\operatorname{ug} / \mathrm{mL}$ & 99.6 & $-6.00 \mathrm{E}-03$ & $3.72 \mathrm{E}+04$ & 38000 & $3.76 \mathrm{E}+04$ & 2.13 & $\mathbf{n} / \mathbf{a}$ & 21 & $n / n$ \\
\hline $595 T 000325$ & & B & Boron-ICP-Acid Digest-Liquid & ug $/ \mathrm{mL}$ & 98.2 & $5.00 \mathrm{E}-03$ & 81.1 & 81.1 & $8.11 \mathrm{E}+01$ & 0 & $\mathbf{n} / \mathbf{a}$ & 21 & $\mathbf{n} / \mathbf{a}$ \\
\hline S95T000325 & & B & Barium -ICP-Acid Digest-Liquid & $\mathrm{ug} / \mathrm{mL}$ & 97.6 & $0.00 \mathrm{E}+00$ & $<21.00$ & $<21.0$ & $n / \mathbf{a}$ & $n / a$ & $n / 6$ & 21 & $\mathfrak{a} / \mathbf{m}$ \\
\hline \$95T000325 & & B & Bisauth -ICP-Acid Digest/Liq & ug $/ \mathrm{mL}$ & 101.6 & $1.00 \mathrm{E}-02$ & $<42.00$ & $<42.0$ & $n / a$ & $n / \mathbf{a}$ & $n / \mathbf{a}$ & 42 & $n / \mathbf{a}$ \\
\hline s95T000325 & & B & Catcium -ICP-Acid Digest-Liq & $\mathrm{ug} / \mathrm{mL}$ & 103.8 & $8.00 \mathrm{E}-03$ & $1.16 \mathrm{E}+02$ & 115 & $1.16 \mathrm{E}+02$ & 0.87 & $n / a$ & 42 & $\mathbf{a} / \mathbf{a}$ \\
\hline s95T000325 & & B & Chromium -ICP-Acid Digest-Liq & $\mathrm{ug} / \mathrm{mL}$ & 102.4 & $0.00 \mathrm{E}+\infty$ & 37.1 & 37.9 & $3.75 \mathrm{E}+01$ & 2.13 & $n / 2$ & 4.2 & $n / \mathbf{a}$ \\
\hline S95T000325 & & B & Iron-ICP-Acid Digest-Liquid & $\mathrm{ug} / \mathrm{mL}$ & 101.2 & $1.00 \mathrm{E}-03$ & $<21.00$ & $<21.0$ & $n / \mathbf{a}$ & $n / 2$ & $n / n$ & 21 & w/a \\
\hline s95T000325 & & $B$ & Potassium -ICP-Acid Digest-Liq & $u g / m L$ & 97.6 & $-9.20 \mathrm{E}-02$ & $3.50 \mathrm{E}+03$ & 3640 & $3.57 \mathrm{E}+03$ & 3.92 & $\mathbf{n} / \mathbf{a}$ & 210 & $n / a$ \\
\hline \$95T000325 & & B & Lithium -ICP-Acid Digest-Liq & ug $/ \mathrm{mL}$ & 98.2 & $1.00 \mathrm{E}-03$ & $<4.200$ & $<4.20$ & $n / a$ & $n / a$ & $\pi / a$ & 4.2 & $n / a$ \\
\hline
\end{tabular}


Table A-1. Laboratory Data Results for Tank 241-SY-103, Core $62^{1}$.

\begin{tabular}{|c|c|c|c|c|c|c|c|c|c|c|c|c|c|}
\hline S-1018. & 8 & $x$ & $x+10$ & 样 & 14 & 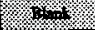 & 4 & $10+14$ & $x, 10$ & swo & 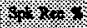 & geno & 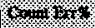 \\
\hline \$95T000325 & & B & Sodium -ICP-Acid Digest-Liquid & $\mathrm{ug} / \mathrm{mL}$ & 98.2 & $6.00 \mathrm{E}-03$ & $1.95 \mathrm{E}+05$ & 199000 & $1.97 \mathrm{E}+05$ & 2.08 & $\mathrm{n} / \mathbf{a}$ & 42 & $n / a$ \\
\hline \$95T000325 & & B & Nickel -ICP-Acid Digest-Liquid & $\operatorname{Lg} / \mathrm{mL}$ & 100.6 & $-6.00 \mathrm{E}-03$ & 47.4 & 48.8 & $4.81 E+01$ & 2.91 & $n / 2$ & 8.4 & $0 / 2$ \\
\hline \$95To00325 & & B & Phosphorus-ICP-Acid Adjust-Liq & $\mathrm{ug} / \mathrm{mL}$ & 100.4 & $-1.10 \mathrm{E}-02$ & $1.15 \mathrm{E}+03$ & 1180 & $1.16 \mathrm{E}+03$ & 2.58 & $n / \mathbf{a}$ & 84 & $n / a$ \\
\hline s95T000325 & & B & Silicon-ICP-Acid Digest-Liq & $\mu \mathrm{g} / \mathrm{mL}$ & 93.2 & $1.90 \mathrm{E}-02$ & $1.17 \mathrm{E}+02$ & 116 & $1.17 \mathrm{E}+02$ & 0.86 & $n / \mathbf{a}$ & 21 & $n / a$ \\
\hline S95T000325 & & B & Uranium -ICP-Acid Digest-Liq & ug/mL & 97.4 & $4.70 \mathrm{E}-02$ & $<2.10 e+02$ & $<210$ & $\mathbf{n} / \mathbf{2}$ & $\mathbf{a} / \mathbf{a}$ & $\mathbf{n} / \mathbf{a}$ & $2.10 \mathrm{E}+05$ & $\mathbf{n} / \mathbf{\imath}$ \\
\hline$\$ 95 \mathrm{~T} 000325$ & & B & Zinc-ICP-Acid Digest-Liquid & ug/mL & 103.2 & $-1.00 \mathrm{E}-03$ & $<4.200$ & $<4.20$ & $\mathbf{n} / \mathbf{a}$ & $\mathbf{n} / \mathbf{a}$ & $\mathbf{a} / \mathbf{a}$ & 4.2 & $\mathbf{n} / \mathbf{2}$ \\
\hline S95T000325 & & B & Zirconium -ICP-Acid Digest-Liq & ug $/ \mathrm{mL}$ & 99 & $4.00 \mathrm{E}-03$ & $<4.200$ & $<4.20$ & $\mathbf{n} / \mathbf{a}$ & $\mathbf{n} / \mathbf{a}$ & $\mathbf{n} / \mathbf{a}$ & 4.2 & $n / 2$ \\
\hline S95T000329 & & D & Uranium by Phosphorescence & $u g / m L$ & 93.03 & $1.98 \mathrm{E}-01$ & 4.06 & 3.8 & $3.93 \mathrm{E}+00$ & 6.62 & 101 & $3,00 \mathrm{E}-02$ & $\mathbf{a} / \mathbf{a}$ \\
\hline \$95T000329 & & D & Alpha in Liquid Samples & uCi/mL & 93.91 & $<8.68 \mathrm{e}-02$ & $<5.19 \mathrm{e}-2$ & $<8.11 \mathrm{e}-2$ & $D / a$ & $n / \mathbf{a}$ & 102.0 & $1.060-01$ & 500.0 \\
\hline$\$ 95 T 000329$ & & D & Beta in Liquid Samples & $\mathrm{uCl} / \mathrm{mL}$ & 105.3 & $<1.910 \mathrm{c} 1$ & $3.65 \mathrm{E}+02$ & 348 & $3.57 \mathrm{E}+02$ & 4.77 & 110.2 & $2.41 \mathrm{E}-01$ & 0.6 \\
\hline S95T000329 & & D & Am-241 by Extraction & $\mathrm{uCJ} / \mathrm{mL}$ & 88.27 & $<1.590 \mathrm{k}-3$ & $2.09 \mathrm{E}-03$ & 0.00191 & $2.00 \mathrm{E}-03$ & 9 & $\boldsymbol{D} / \mathbf{a}$ & $1.00 \mathrm{E}-03$ & 8.9 \\
\hline S95T000329 & & $\mathrm{D}$ & $\mathrm{Cm}-243 / 244$ by Extraction & $u C \mathrm{C} / \mathrm{mL}$ & $n / m$ & $<1.590 \mathrm{k}-3$ & $<1.10 k-03$ & $<1.14 c-3$ & $a / \mathbf{a}$ & $n / a$ & $n / a$ & $1.00 \mathrm{E}-03$ & 29.5 \\
\hline S95T000329 & & D & Cobalt-60 by GEA & $\mathrm{uC} / \mathrm{mL}$ & 104 & $<5.320 \mathrm{e}-4$ & $2.72 \mathrm{E}-02$ & 0.0238 & $2.55 \mathrm{E}-02$ & 13.3 & $n / 2$ & $1.00 \mathrm{E}-03$ & 32.01 \\
\hline$\$ 95 T 000329$ & & D & Cesium-137 by $\mathrm{OEA}$ & $\mathrm{uCv} / \mathrm{mL}$ & 100 & $<8.020 \times-4$ & $3.80 \mathrm{E}+02$ & 368 & $3.74 \mathrm{E}+\mathbf{0 2}$ & 3.21 & $\mathbf{n} / \mathbf{a}$ & $1.00 \mathrm{E}-03$ & 0.16 \\
\hline $595 T 000329$ & & D & Europium-1 54 by GEA & $\mathrm{uCi} / \mathrm{mL}$ & n/a & $<1.330 \mathrm{e}-3$ & $<7.98 \mathrm{e}-02$ & $<7.32 \mathrm{e}-2$ & $\mathbf{n} / \mathbf{a}$ & $\mathbf{a} / \mathbf{a}$ & $\mathbf{n} / \mathbf{a}$ & $1.00 \mathrm{E}-03$ & $\mathbf{n} / \mathbf{a}$ \\
\hline S95T000329 & & D & Europium-155 by GEA & $\mathrm{uCl} / \mathrm{mL}$ & $\mathbf{a} / \mathbf{a}$ & $<1.180 \mathrm{c}-3$ & $<2.44 e-01$ & $<2.42 c-1$ & $n / \mathbf{a}$ & n/a & $\mathbf{n} / \mathbf{a}$ & $1.00 \mathrm{E}-03$ & $n / a$ \\
\hline s95T0001329 & d, $e$ & D & Tritium By Lachat & $\mathrm{uCi} / \mathbf{m L}$ & 100 & $<6.950 \mathrm{e}-5$ & 3.16E-04 & 0.00332 & $1.82 \mathrm{E}-03$ & 165 & $2.16 \mathrm{E}+03$ & $6.95 \mathrm{E}-05$ & 4.67 \\
\hline S95T000329 & & D & Np237 by TTA Excraction & $\mathrm{uCi} / \mathrm{mL}$ & 82.92 & $<4.120 x-4$ & $<7.89+04$ & $<4.42 e-4$ & $\mathbf{n} / \mathbf{a}$ & $\mathbf{w} / \mathbf{a}$ & 81.6 & $1.00 \mathrm{E}-03$ & 141.3 \\
\hline
\end{tabular}


Table A-1. Laboratory Data Results for Tank 241-SY-103, Core $62^{1}$.

\begin{tabular}{|c|c|c|c|c|c|c|c|c|c|c|c|c|c|}
\hline simet & 8 & 18 & $(1+1)$ & 13. & $4 x$ & 10 & 6 & hoph & 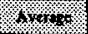 & 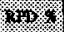 & $40 \%$ & mon & $8 x^{2}+1$ \\
\hline s95T000329 & & D & Pu-238 by Ion Exchange & $\mathrm{uCl} / \mathrm{mL}$ & $n / a$ & $<5.900-5$ & $<6.41 \mathrm{e}-05$ & $<6.51 \mathrm{e}-5$ & $\mathrm{n} / \mathrm{a}$ & $n / a$ & $\mathbf{n} / \mathbf{a}$ & $6.4 \mathrm{LE}-05$ & 15.7 \\
\hline \$95T000329 & & D & Pu-239/240 by TRU-SPEC Resin & $\mathrm{uCi} / \mathrm{mL}$ & 93.75 & $<5.900 \mathrm{k}-5$ & $6.80 \mathrm{E}-05$ & $7.28 \mathrm{E}-05$ & 7.04E-05 & 6.82 & $\mathbf{n} / \mathbf{m}$ & $6.41 \mathrm{E}-05$ & 8.7 \\
\hline 5957000329 & & D & Strontium-89/90 High Level & $\mathrm{uCi} / \mathrm{mL}$ & 91.89 & $<3.690 \mathrm{e}-2$ & 2.5 & 2.3 & $2.40 \mathrm{E}+\infty$ & 8.33 & $n / \mathbf{n}$ & $5.20 \mathrm{E}-02$ & 6 \\
\hline S95T000329 & & D & Technctium-99 Liq. Scint. & uCi/mI. & 96.68 & $1.00 \mathrm{E}-03$ & $1.44 \mathrm{E}-01$ & 0.149 & $1.46 \mathrm{E}-01$ & 3.41 & $a / \mathbf{a}$ & $1.00 \mathrm{E}-03$ & 1.05 \\
\hline S95T000333 & & $\mathrm{v}$ & OH- by Por. Titration & $\mathrm{ug} / \mathrm{mL}$ & 99.38 & $<\$ 167.0$ & $2.96 \mathrm{E}+04$ & 28900 & $2.92 \mathrm{E}+04$ & 2.39 & $n / n$ & 4.17E+03 & $n / \mathbf{a}$ \\
\hline \$95T000333 & & v & Chromium (VI) by Spec. & $\mathrm{ug} / \mathrm{mL}$ & 102.2 & $<3.900 \mathrm{e}-2$ & $<\quad 3.939$ & 12.4 & $n / a$ & $n / a$ & $\mathrm{n} / \mathbf{n}$ & 3.939 & $n / \mathbf{a}$ \\
\hline s95T000333 & & $v$ & Iodine-129 Waste Tank Samples & $\mathrm{uCl} / \mathrm{mL}$ & 81.65 & $<5.910 \mathrm{c} 4$ & $1.90 \mathrm{E}-(04$ & 0.000193 & $1.91 \mathrm{E}-\mathrm{A4}$ & 1.57 & $n / \mathbf{a}$ & $1.00 \mathrm{E}-03$ & 34 \\
\hline s95T0001333 & & $\mathbf{v}$ & Bromide by Ion Chromatograph & ug/mL & 100 & $<40.80$ & $<4.08 \mathrm{e}+03$ & $<4.08 \mathrm{e3}$ & $\mathbf{n} / \mathbf{a}$ & $\mathrm{n} / \mathbf{a}$ & $n / \mathbf{n}$ & $4.08 \mathrm{E}+03$ & $a / a$ \\
\hline s95T000333 & & v & Chloride-IC-Dionex $4000 \mathrm{i} / 4500$ & ug $/ \mathrm{mL}$ & 101.9 & $<5.100$ & $1.17 \mathrm{E}+04$ & 11000 & $1.14 \mathrm{E}+04$ & 6.17 & $\mathbf{n} / \mathbf{a}$ & 510 & $\mathrm{n} / \mathbf{a}$ \\
\hline S95T000333 & & $\mathbf{v}$ & Fluoride-IC-Dionex $4000 \mathrm{i} / 4500$ & ug/mL & 96.79 & $<3.060$ & $<3.06 e+02$ & $<3.06 \mathrm{e} 2$ & $n / a$ & $\mathbf{n} / \mathbf{a}$ & $n / n$ & 306 & $\mathbf{n} / \mathbf{a}$ \\
\hline s95T000333 & & v & Nitrite-IC - Dicaex 4000/4500 & $\log / \mathrm{mL}$ & 93.51 & $<40.80$ & $1.43 E+05$ & 134000 & $1.38 \mathrm{E}+05$ & 6.5 & $n / h$ & $4.08 \mathrm{E}+03$ & $n / \mathbf{a}$ \\
\hline S95T000333 & & $\mathbf{v}$ & Nitrate-IC - Dionex $4000 \mathrm{j} / 4500$ & $\mathrm{ug} / \mathrm{mL}$ & 102.2 & $<51.00$ & $1.78 \mathrm{E}+05$ & 167000 & $1.72 \mathrm{E}+05$ & 6.38 & $\mathbf{n} / \mathbf{a}$ & $5.10 \mathrm{E}+03$ & $n / a$ \\
\hline S95T000333 & & $\mathbf{v}$ & Oxalate by IC - Dionex $4000 \mathrm{i}$ & $\mathbf{u g} / \mathrm{ml}$ & 91.68 & $<25.50$ & $<2.55 \mathrm{e}+03$ & $<2.55 \mathrm{se}$ & $n / n$ & $\mathbf{n} / \mathbf{a}$ & $\mathrm{n} / \mathbf{a}$ & $2.55 \mathrm{E}+03$ & a/a \\
\hline S95T000333 & & $\mathbf{v}$ & Phosphate-IC-Dionex 4000i/4500 & $\mathrm{ug} / \mathrm{mL}$ & 96.32 & $<30.60$ & $3.38 \mathrm{E}+03$ & 2980 & $3.18 \mathrm{E}+03$ & 12.6 & $\mathrm{n} / \mathbf{a}$ & $3.06 \mathrm{E}+03$ & a/a \\
\hline S95T000333 & & $\mathbf{v}$ & Sulfate by IC-Dionex $4000 \mathrm{~V} 4500$ & $\operatorname{ug} / \mathrm{mL}$ & 101.7 & $<40.80$ & $<4.08 \mathrm{e}+03$ & $<4.08 \mathrm{e} 3$ & $n / \mathbf{2}$ & $n / \mathbf{a}$ & $\mathbf{n} / \mathbf{a}$ & $4.08 \mathrm{E}+03$ & $\mathbf{n} / \mathbf{a}$ \\
\hline S95T000333 & & $\mathbf{v}$ & Acetate by IC - Dionex $4000 \mathrm{i}$ & $\mathrm{ug} / \mathrm{mL}$ & $n / 4$ & $<2.000 \mathrm{k}-1$ & $1.32 \mathrm{E}+03$ & 1340 & $1.33 \mathrm{E}+03$ & 1.5 & $\mathbf{n} / \mathbf{a}$ & 220 & a/a \\
\hline \$95T000333 & & $\mathbf{v}$ & Formate by Ion Chromatograph & $\mathrm{ug} / \mathrm{mL}$ & $n / \mathbf{a}$ & $<2.000-1$ & $4.23 \mathrm{E}+03$ & 4340 & $4.28 \mathrm{E}+03$ & 2.57 & $\mathrm{n} / \mathrm{a}$ & 220 & $\mathrm{n} / \mathrm{a}$ \\
\hline
\end{tabular}


Table A-1. Laboratory Data Results for Tank 241-SY-103, Core 62'.

\begin{tabular}{|c|c|c|c|c|c|c|c|c|c|c|c|c|c|}
\hline sompley & 8 & $x$ & 1014 & 10 & 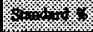 & 4 & Kon & $64 x_{0}$ & 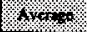 & $3 \%$ & $x_{1} x=4$ & $4 x$ & $x=11 \%$ \\
\hline \multicolumn{14}{|c|}{ Stratum "C" Composite Solids } \\
\hline S94T000058 & & & \% Water by TGA using Metuler & $\%$ & 99.2 & $n / a$ & 46.03 & 44.64 & $4.53 \mathrm{E}+0 \mathrm{t}$ & 3.07 & $n / \mathbf{a}$ & $1.00 \mathrm{E}-02$ & $\mathrm{n} / \mathrm{a}$ \\
\hline $594 \mathrm{~T} 000058$ & & & DSC Exocherm Dry Calculated & Joules/g Dry & $\mathrm{n} / \mathbf{a}$ & $\mathbf{n} / \mathbf{a}$ & $3.22 \mathrm{E}+02$ & 316.3 & $3.19 \mathrm{E}+02$ & 1.63 & $\mathbf{n} / \mathbf{a}$ & $1.00 \mathrm{E}-01$ & $\mathrm{n} / \mathbf{a}$ \\
\hline S94T000058 & & & DSC Exotherm using Metuler & Joules/g & 104.7 & $\mathbf{n} / \mathbf{s}$ & $1.74 \mathrm{E}+02$ & 175.1 & $1.74 E+02$ & 0.92 & $\mathbf{n} / \mathbf{a}$ & $\mathrm{n} / \mathrm{a}$ & $\mathbf{n} / \mathbf{a}$ \\
\hline S94T000067 & d & $\mathbf{F}$ & Uramium by Phosphorescence & ug/ $/ \varepsilon$ & 98.26 & 1.81 & $6.49 \mathrm{E}+02$ & 602 & $6.26 \mathrm{E}+02$ & 7.51 & 123 & 1.31 & $n / a$ \\
\hline S94T000067 & e & $F$ & Alpha of Digested Solid & $\mathrm{wCi} / \mathbf{g}$ & 91.61 & $<2.120 \mathrm{k}-1$ & $8.71 \mathrm{E}-01$ & 0.589 & 7.30E-01 & 38.6 & 99.1 & $4.28 \mathrm{E}-01$ & 53.3 \\
\hline S94T000067 & c & F & Am-241 by Extraction & $\mathrm{uCi} / \mathrm{g}$ & 100.8 & $<1,580 k-1$ & $6.13 \mathrm{E}-01$ & 0.484 & $5.48 \mathrm{E}-01$ & 23.5 & $\mathbf{a} / \mathbf{a}$ & $1.44 \mathrm{E}-01$ & 6.1 \\
\hline S94T000067 & & $F$ & Cm-243/244 by Extraction & uCi'g & $\mathrm{n} / \mathrm{n}$ & $<1.580 \mathrm{c}-1$ & $<1.44 \mathrm{e}-01$ & $<3.20 \mathrm{c}-1$ & $n / 2$ & $n / n$ & $\mathbf{n} / \mathbf{a}$ & $1.44 \mathrm{E}-01$ & 25.3 \\
\hline S94T000067 & & $\mathbf{F}$ & Beta of Solid Sample & $\mathrm{uCi} / \mathrm{g}$ & 91.36 & 3.07 & $4.30 \mathrm{E}+02$ & 406 & $4.18 \mathrm{E}+02$ & 5.74 & 87.8 & 2.28 & 1.6 \\
\hline S94T000067 & & $\mathbf{F}$ & Cesium- 137 by GEA & $\omega \mathrm{Ci} / \mathrm{g}$ & 98.47 & $4.49 \mathrm{E}-01$ & $2.93 \mathrm{E}+02$ & 296 & $2.95 \mathrm{E}+02$ & 1.02 & $\mathbf{n} / \mathbf{a}$ & $4.49 \mathrm{E}-01$ & 0.94 \\
\hline s94T000067 & & $\mathbf{F}$ & Iodine-129 Waste Tank Samples & $\mathrm{uCV} / \mathrm{g}$ & 100 & $<6,020 \mathrm{e}-2$ & $<6.22 e-02$ & $<8.22 \mathrm{e}-2$ & $n / a$ & $n / a$ & $\mathbf{n} / \mathbf{a}$ & $6.20 \mathrm{E}-02$ & $\mathbf{D} / \mathbf{a}$ \\
\hline S94T000067 & & $\mathbf{F}$ & Aluminium -JCP-Fusion & $\mu \mathrm{g} / \mathrm{g}$ & 98.6 & $2.90 \mathrm{E}-01$ & $3.89 \mathrm{E}+04$ & 36100 & $3.75 \mathrm{E}+04$ & 7.47 & $n / 2$ & 275 & $n / \mathbf{a}$ \\
\hline $594 \mathrm{r} 000067$ & & $\mathbf{F}$ & Calcium -ICP-Fusion & $4 \mathrm{~g} / \mathrm{g}$ & 101.4 & $2.50 \mathrm{E}-01$ & $8.08 \mathrm{E}+02$ & LDL & $n / 2$ & $n / 2$ & $n / \mathbf{n}$ & 549 & $n / a$ \\
\hline S94T000067 & e & $\mathbf{F}$ & Chromiurn-ICP-Fusion & $\mathrm{ug} / \mathrm{g}$ & 102.2 & $2.90 \mathrm{E}-02$ & $6.23 \mathrm{E}+03$ & 5070 & $5.65 E+03$ & 20.5 & $\mathbf{n} / \mathbf{a}$ & 54.9 & $n / n$ \\
\hline $594 T 000067$ & & $\mathbf{F}$ & Iron-ICP-Fusion & $\mathrm{ug} / \mathrm{g}$ & 101.2 & $9.00 \mathrm{E}-02$ & $1.56 \mathrm{E}+03$ & 1360 & $1.46 \mathrm{E}+03$ & 13.7 & $n / a$ & 275 & $n / \mathbf{a}$ \\
\hline S94T000667 & & $\mathbf{F}$ & Potassium -ICP-Fusion (2) & us/g & 96.6 & $-1.40 \mathrm{E}-02$ & $n / \mathbf{a}$ & $n / \mathbf{a}$ & $n / 2$ & $n / 2$ & $n / 2$ & $5.49 \mathrm{E}+03$ & $\mathbf{a} / \mathbf{m}$ \\
\hline S94T000067 & & $\mathbf{F}$ & Sodiun -ICP-Fusion & $\mathrm{ug} / \mathrm{g}$ & 97.4 & 4.65 & $1.77 \mathrm{E}+05$ & 166000 & $1.72 \mathrm{E}+05$ & 6.41 & $n / a$ & 549 & $\mathrm{n} / \mathbf{a}$ \\
\hline S94T000067 & & $\mathbf{F}$ & Nickel -ICP-Fusion (2) & ug/z & 101.8 & 10.4 & $n / 2$ & $\mathbf{n} / \mathbf{a}$ & $n / a$ & $\mathrm{n} / \mathrm{a}$ & $n / n$ & 110 & $n / \mathbf{a}$ \\
\hline S94T000067 & & $\mathbf{F}$ & Zine-ICP-Fusion & ug/g & 103.6 & $2.00 \mathrm{E}-02$ & $<54.90$ & 14.1 & $n / a$ & D/a & $n / 2$ & 54.9 & $0 / 2$ \\
\hline
\end{tabular}


Table A-1. Laboratory Data Results for Tank 241-SY-103, Core $62^{1}$.

\begin{tabular}{|c|c|c|c|c|c|c|c|c|c|c|c|c|c|}
\hline sanplot: & 0. & $\%$ & Shyoto & tinit & 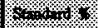 & $1+1$ & Nor. & 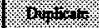 & 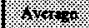 & (xin 4 & 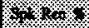 & 1) & 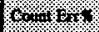 \\
\hline S94 T000067 & & $\mathbf{F}$ & Zirconium -ICP-Fusion & $\mathrm{ug} / \mathrm{g}$ & 99.8 & $1.22 \mathrm{E}-01$ & $<54.90$ & 135 & $\mathbf{n} / \mathbf{a}$ & $\mathbf{n} / \mathbf{2}$ & $\mathrm{n} / \mathbf{a}$ & 54.9 & a/: \\
\hline $594 \mathrm{~T} 000067$ & & $\mathbf{F}$ & Lithium -ICP-Fusion & og $/ \mathrm{g}$ & 100.6 & $2.10 \mathrm{E}-01$ & LDL & LDL & $n / n$ & $\mathbf{n} / \mathbf{a}$ & $n / \mathbf{2}$ & 60.4 & $n / a$ \\
\hline \$94T000067 & & F & Np237 by TTA Extraction & uCi'g & 85.4 & $\mid<1.180-2$ & $<1.01 e-12$ & $<1.25 c-2$ & $n / a$ & $\mathbf{n} / \mathbf{a}$ & 82.7 & $2.10 \mathrm{E}-02$ & 145.4 \\
\hline $594 \mathrm{~T} 0000067$ & & F & Pu-238 by lon Exchange & |uCi/g & $\mathbf{a} / \mathbf{a}$ & $<3.1500-1$ & $<2.01 \mathrm{e}-01$ & $<3.51 \mathrm{e}-1$ & $\mathbf{n} / \mathbf{a}$ & $n / a$ & $\mathbf{n} / \mathbf{2}$ & $2.01 \mathrm{E}-01$ & 100 \\
\hline S94T000067 & f & $\mathbf{F}$ & Pu-239/240 by TRU-SPEC Resin & uCi'g & 102.1 & $3.90 \mathrm{E}-01$ & $3.79 \mathrm{E}-01$ & 0.419 & $3.99 \mathrm{E}-01$ & 10 & $n / a$ & $2.01 \mathrm{E}-0 \mathrm{l}$ & 5.3 \\
\hline S94T000067 & & $\mathbf{F}$ & Strontium-89/90 High Level & $\mathrm{uCi} / \mathrm{g}$ & 99.11 & $7.40 \mathrm{E}-02$ & 34.9 & 29.1 & $3.20 \mathrm{E}+01$ & 18.1 & $n / n$ & $1.00 \mathrm{E}-03$ & 0.2 \\
\hline S94T000067 & & $\mathbf{F}$ & Technetium-99 Liq. Scint. & uCi/g & 86.72 & $1.60 \mathrm{E}-02$ & $2.28 \mathrm{E}-01$ & 0.225 & $2.27 \mathrm{E}-01$ & 1.32 & 82 & $1.50 \mathrm{E}-02$ & 3.5 \\
\hline \$94T00000 & & & Bulk Density of Sample & $\mathrm{g}^{\prime} \mathrm{mL}$ & $\mathbf{n} / \mathbf{2}$ & $\mathbf{n} / \mathbf{a}$ & 1.51 & $n / a$ & $\mathbf{n} / \mathbf{n}$ & $n / n$ & $n / \mathbf{a}$ & $5.00 \mathrm{E}-01$ & $\mathrm{n} / \mathbf{a}$ \\
\hline S94T000274 & & & pH on SST Samples & pH & 100.2 & $n / a$ & 13.04 & 12.98 & $1.30 \mathrm{E}+01$ & 0.46 & $\mathbf{D} / \mathrm{a}$ & $1.00 \mathrm{E}-02$ & n/a \\
\hline \$94T000274 & & & TOC by Persulfate/Coulometry & $\log / \mathrm{g}$ & 89.33 & 33.8 & $1.00 E+04$ & 9150 & $9.58 \mathrm{E}+03$ & 8.88 & $a / \mathbf{a}$ & 80 & w/n \\
\hline S94 T000274 & & & TIC by Acid/Coulometry & ug $/ \mathrm{g}$ & 97.00 & 4.500 & $6.45 e+03$ & $6.37 e+03$ & $6.41 e+03$ & 1.25 & $\mathbf{n} / \mathbf{a}$ & 5.000 & 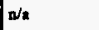 \\
\hline s94T00027 & & A & Aluminium -ICP-Acid Digest & ug/g & 97.6 & $2.60 \mathrm{E}-0$ & $2.64 \mathrm{E}+04$ & 24200 & $2.53 \mathrm{E}+04$ & 8.7 & $\mathbf{n} \mathbf{z}$ & 24.5 & $\mathrm{w} / \mathbf{n}$ \\
\hline s94T000027 & & A & Calciunn -ICP-Acid Digest & ug/g & 101.2 & $2.10 \mathrm{E}-02$ & $1.10 \mathrm{E}+02$ & 107 & $1.09 \mathrm{E}+02$ & 2.77 & $\mathbf{a} / \mathbf{a}$ & 49 & $\mathrm{n} / \mathrm{a}$ \\
\hline $594 \mathrm{~T} 0002 \pi$ & & $A$ & Chromium -ICP-Acid Digest & $\log / \varepsilon$ & 95.8 & $1.10 \mathrm{E}-02$ & $2.65 \mathrm{E}+02$ & 240 & $2.53 \mathrm{E}+02$ & 9.9 & $\mathrm{n} / \mathbf{2}$ & 4.9 & $\mathrm{n} / \mathrm{a}$ \\
\hline S94T00027 & & A & Iron -ICP-Acid Digest & $\mathrm{ug} / \mathrm{g}$ & 96.6 & $4.40 \mathrm{E}-02$ & 80.9 & 74.5 & $7.77 \mathrm{E}+01$ & 8.24 & $\mathbf{a} / \mathbf{a}$ & 24.5 & $\mathbf{n} / \mathbf{a}$ \\
\hline s94T00027 & b & A & Potsssium -ICP-Acid Digest & ug/g & 121 & 2.15 & $3.18 \mathrm{E}+03$ & 2900 & $3.04 E+03$ & 9.21 & $\mathbf{n} / \mathbf{a}$ & 147 & $a / a$ \\
\hline s94700027 & & $A$ & Sodium -ICP-Acid Digest & ug/g & 99.2 & 1.14E-01 & $1.53 \mathrm{E}+05$ & 141000 & $1.47 \mathrm{E}+05$ & 8.16 & $\alpha / \mathbf{t}$ & 98 & $\mathrm{n} / \mathbf{a}$ \\
\hline s94T000277 & & A & Nickel-ICP-Acid Digest & $\mathrm{ug} / \mathrm{g}$ & 94.6 & 7.00E-03 & 30.2 & 27.6 & $2.89 \mathrm{E}+01$ & 9 & $\mathbf{n} / \mathbf{a}$ & 9.8 & $\mathbf{n} / \mathbf{a}$ \\
\hline
\end{tabular}




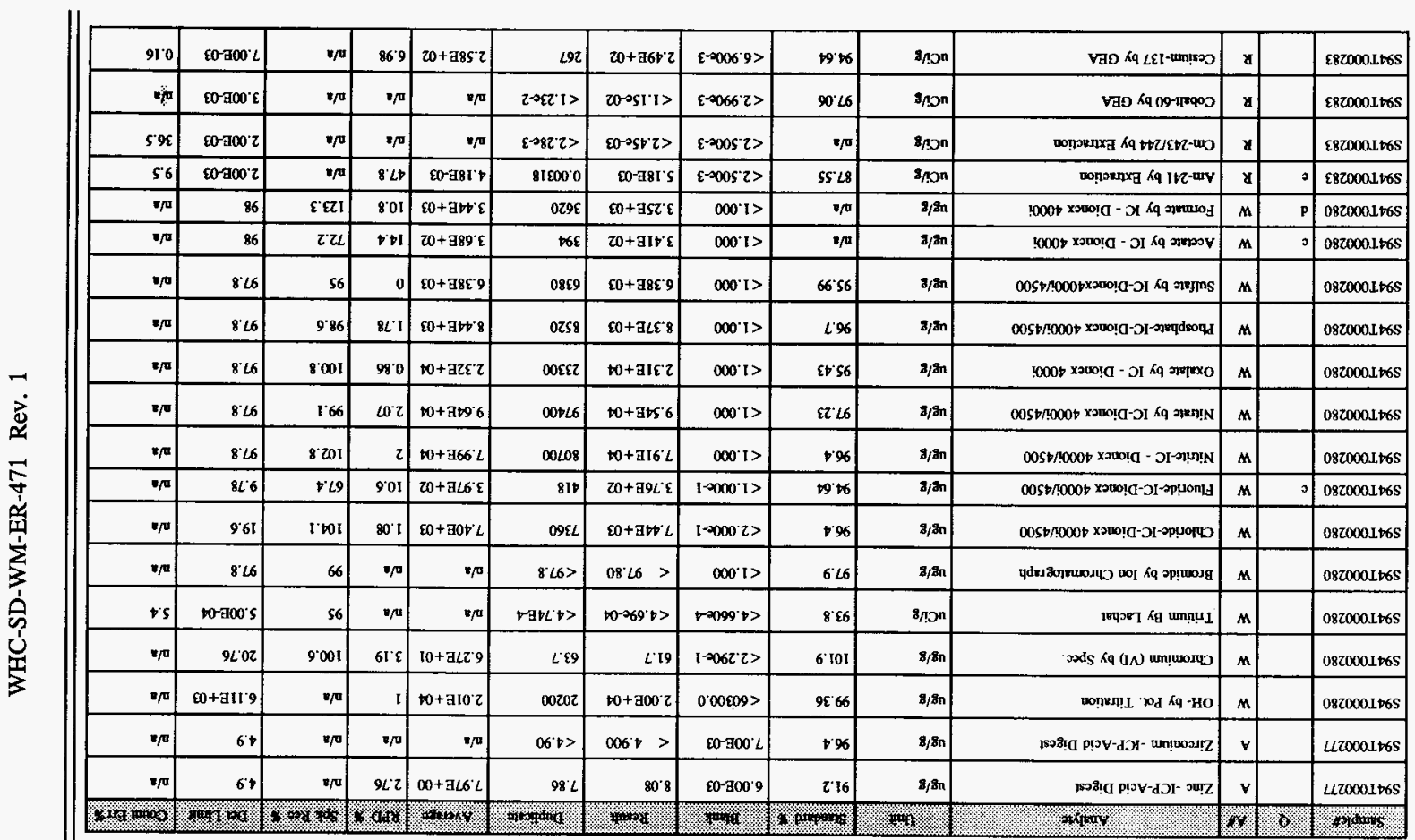

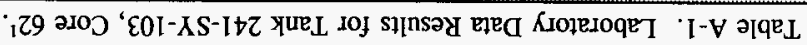


Table A-1. Laboratory Data Results for Tank 241-SY-103, Core 621.

\begin{tabular}{|c|c|c|c|c|c|c|c|c|c|c|c|c|c|}
\hline sanplef & 0 & 16 & 6 & 1) & bind & 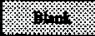 & X & 3. & 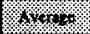 & \& & 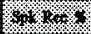 & I & 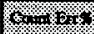 \\
\hline S94T000283 & & $\mathbf{R}$ & Europium-154 by GEA & uCi/g & $n / \mathbf{a}$ & $<6.390 \mathrm{e}-3$ & $<5.05 \mathrm{e}-02$ & $<5.95 \mathrm{e}-2$ & $n / a$ & $\mathbf{n} / \mathbf{a}$ & $n / \mathbf{a}$ & $6.00 \mathrm{E}-03$ & $\mathrm{r} / \mathrm{a}$ \\
\hline S94T000283 & & $\mathbf{R}$ & Europium- 155 by GEA & $\mathrm{uCi} / \mathrm{g}$ & $\mathbf{a} / \mathbf{a}$ & $<7.000 \mathrm{e}-3$ & $<1.83 \mathrm{e}-01$ & $<1.90 \mathrm{c}-1$ & $n / a$ & $n / a$ & $n / a$ & $7.00 \mathrm{E}-03$ & nila \\
\hline S94T000283 & c & $\mathbf{R}$ & Np237 by TTA Extraction & $\mathrm{uCi} / \mathrm{g}$ & 80.17 & $<2.420 k-3$ & $<3.50=-03$ & $<2.45 \mathrm{e}-3$ & n'a & $n / a$ & 73.8 & $5.00 \mathrm{E}-03$ & 291.7 \\
\hline S94T000283 & & $\mathbf{R}$ & Pu-238 by Ion Exchange & $\mathrm{uCi} / \mathrm{g}$ & $n / \mathbf{a}$ & $<7.940<-4$ & $<6.76 \mathrm{e}-04$ & $<4.30=-4$ & $n / a$ & $n / a$ & $n / a$ & $1.00 \mathrm{E}-03$ & 100 \\
\hline$\$ 94 \mathrm{~T} 000283$ & e & $\mathbf{R}$ & Pu-239/240 by TRU-SPEC Resin & $u C i / g$ & 113.4 & $<7.940-4$ & $7.00 \mathrm{E}-04$ & 0.000472 & $5.86 \mathrm{E}-04$ & 38.9 & $n / a$ & $1.00 \mathrm{E}-03$ & 9.6 \\
\hline S94T000283 & e & $\mathbf{R}$ & Strontium-89/90 High Level & $\mathrm{uCi} / \mathrm{g}$ & 93.69 & $2.00 E-03$ & 1.88 & 2.43 & $2.16 \mathrm{E}+\infty$ & 25.5 & $\mathbf{n} / \mathbf{a}$ & 2.00E-03 & 1.4 \\
\hline S95T000295 & & $\mathbf{R}$ & Tochnetium-99 Liq. Scint. & $\mathrm{uCi} / \mathrm{g}$ & 101.2 & $<1.750 \mathrm{e}-3$ & $1.68 \mathrm{E}-01$ & 0.16 & $1.64 \mathrm{E}-01$ & 4.88 & $n / 2$ & $2.00 \mathrm{E}-03$ & 1.65 \\
\hline \multicolumn{14}{|c|}{ Drainble Liquid } \\
\hline$\$ 94 T 000108$ & & & \& Water by TGA using Metuler & \% & 99 & $n / a$ & 48.7 & 48.95 & $4.88 \mathrm{E}+01$ & 0.51 & $n / 2$ & $1.00 \mathrm{E}-02$ & $\mathbf{w} / \mathbf{a}$ \\
\hline S94T000108 & & & DSC Exotherm using Mettier & Joules/g & 100.2 & $n / 2$ & $2.88 \mathrm{E}+02$ & 285.1 & $2.86 \mathrm{E}+02$ & 0.87 & $n / a$ & $\mathrm{n} / \mathrm{a}$ & $n / \mathbf{a}$ \\
\hline S94T000I 12 & & D & Lithium-ICP-Acid Dit. & $\mathrm{ug} / \mathrm{mL}$ & 100.6 & $0.00 E+\infty$ & LDL & LDL & $\mathrm{n} / \mathbf{a}$ & $n / \mathbf{a}$ & $n / a$ & 11 & $\mathrm{a} / \mathbf{a}$ \\
\hline
\end{tabular}


Table A-1. Laboratory Data Results for Tank 241-SY-103, Core 62'.

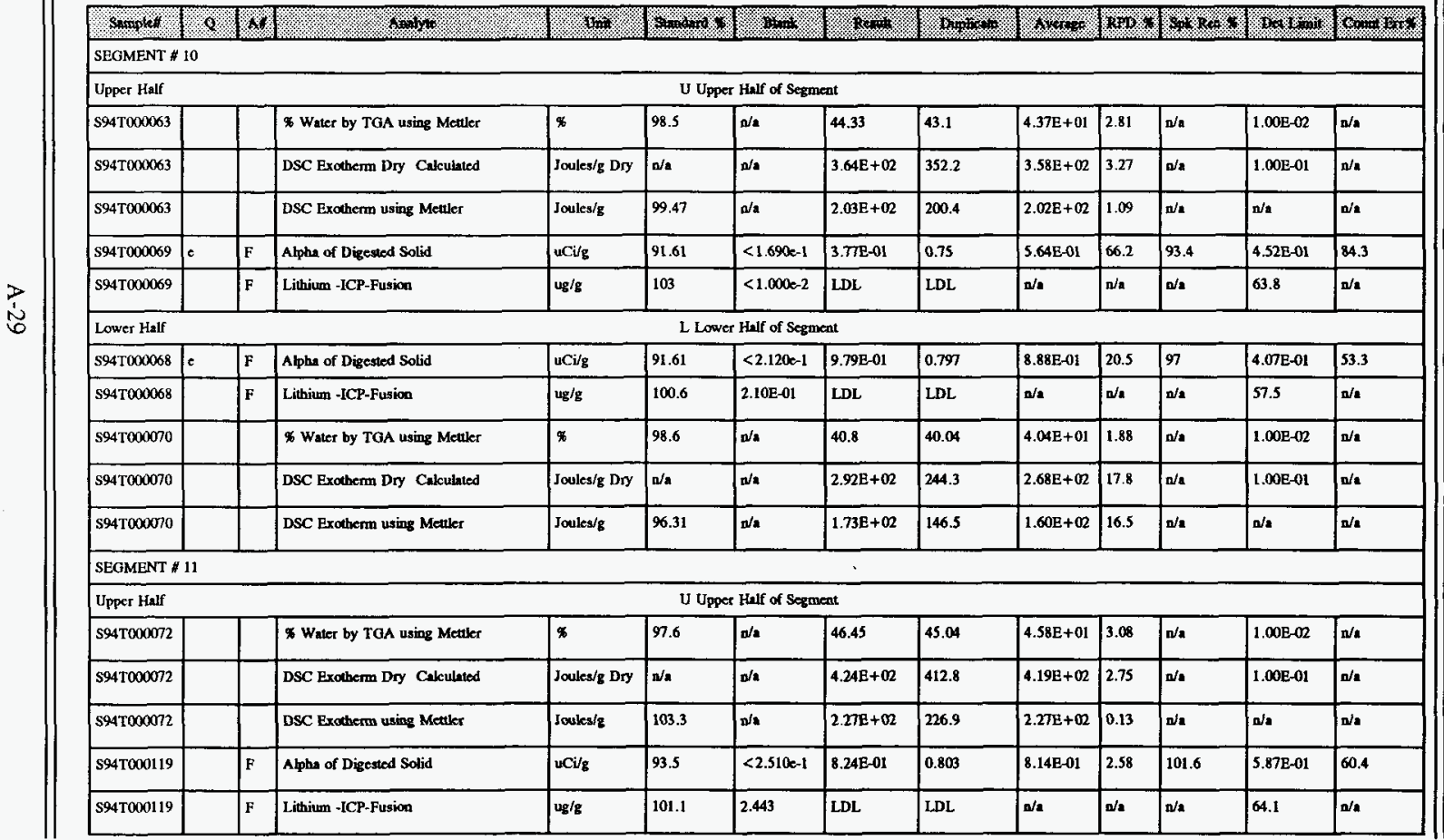


Table A-1. Laboratory Data Results for Tank 241-SY-103, Core 62 ${ }^{1}$.

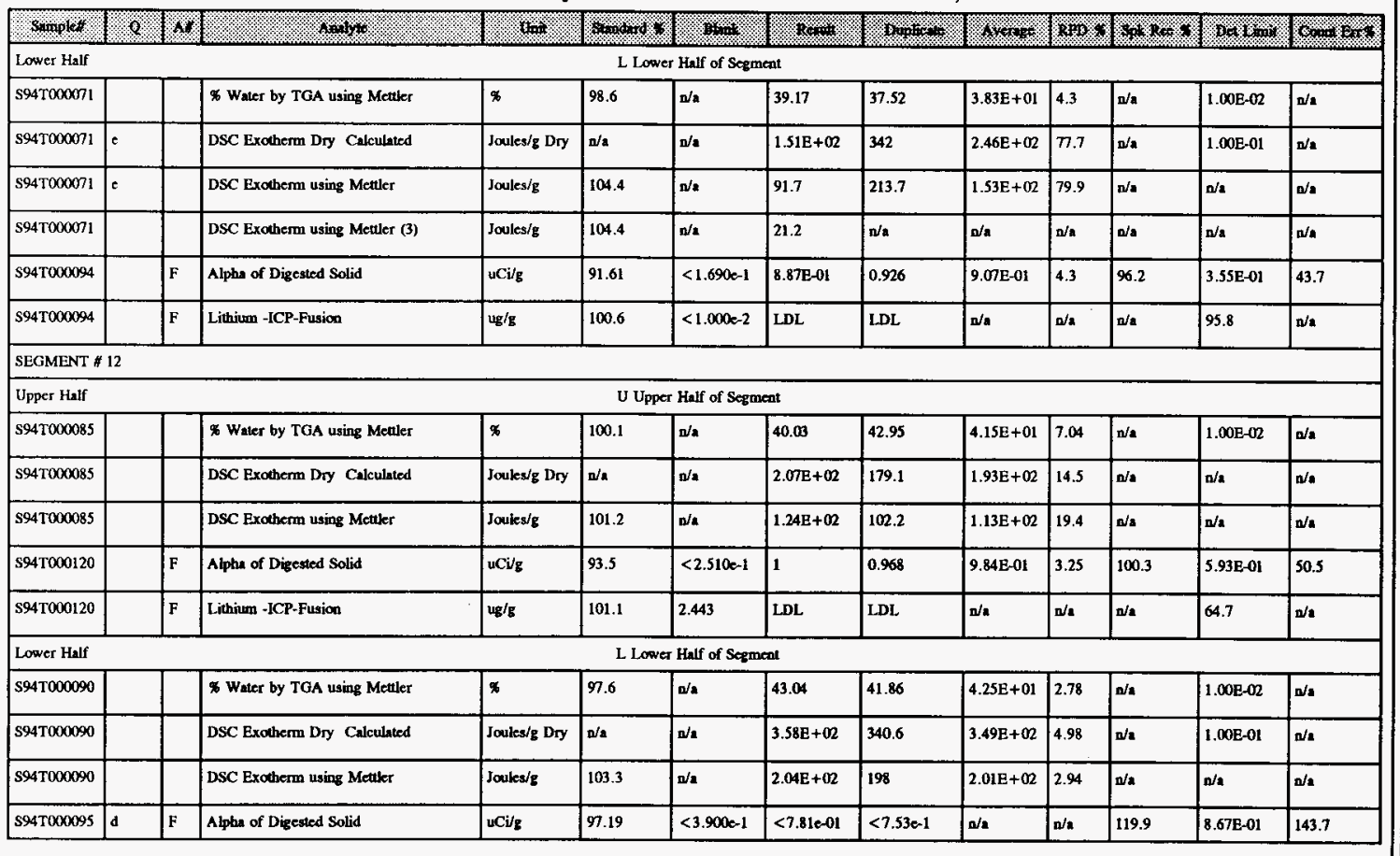


Table A-1. Laboratory Data Results for Tank 241-SY-103, Core 621.

\begin{tabular}{|c|c|c|c|c|c|c|c|c|c|c|c|c|c|}
\hline surpory & (6. & 1. & ining & tip & 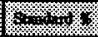 & 4 & 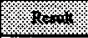 & $10 \%=6$ & 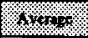 & $\mathrm{NHO} \times \mathrm{H}$ & (2) & $(1+4)=13$ & 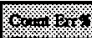 \\
\hline S94T000095 & & $\mathrm{F}$ & Lithium -ICP.Fusion & ug/g & 98.4 & $<1.000 k-2$ & LDL. & LDL & $\mathrm{n} / \mathbf{a}$ & $a / a$ & $\pi / a$ & 54.1 & $0 / \mathbf{a}$ \\
\hline
\end{tabular}


Table A-1. Laboratory Data Results for Tank 241-SY-103, Core $62^{1}$.

\begin{tabular}{|c|c|c|c|c|c|c|c|c|c|c|c|c|c|}
\hline stingler & 8 & ais & 1010 & 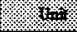 & 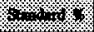 & 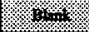 & mon & Woph & $x \times 1 \%$ & $2=0 \%$ & 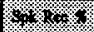 & 6 (8) & 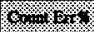 \\
\hline \multicolumn{14}{|c|}{ SEGMENT \# 13} \\
\hline \multicolumn{5}{|c|}{ SEGMENT PORTION } & \multicolumn{3}{|c|}{ Liner Liquid } & & & & & & \\
\hline$\$ 95 \mathrm{~T} 000284$ & & & Toh. Organic Carbon by Coul. & ug $/ \mathrm{mL}$ & 99.67 & $<5.000$ & $4.36 \mathrm{E}+103$ & 4270 & $4.32 \mathrm{E}+03$ & 2.09 & $\mathbf{n} / \mathbf{a}$ & 105 & $n / a$ \\
\hline S95T000284 & & & \% Water by TOA using Mettler & $\%$ & 98.83 & $\mathrm{n} / \mathbf{a}$ & 69.58 & 69.48 & $6.95 \mathrm{E}+01$ & 0.14 & $n / a$ & $n / 2$ & $n / a$ \\
\hline$\$ 95 T 000284$ & & & pH Direct & pH & 99.32 & $n / a$ & 13.63 & N/A & $n / \mathbf{a}$ & $\mathbf{n} / \mathbf{a}$ & $n / a$ & $1.00 \mathrm{E}-02$ & $\mathbf{n} / \mathbf{a}$ \\
\hline S95T000284 & & & DSC Exotherm using Metuler & Joules/g & 95.96 & $n / \mathbf{a}$ & $0.00 \mathrm{E}+\infty 0$ & 0 & $0.00 \mathrm{E}+00$ & $\mathbf{n} / \mathbf{a}$ & $\mathrm{a} / \mathbf{a}$ & n/a & $n / a$ \\
\hline$\$ 95 T 000326$ & e & B & Aluminium -ICP-Acid Digest-Liq & ug/mL & 99.6 & $-6.00 \mathrm{E}-03$ & $5.15 E+03$ & 4320 & $4.74 \mathrm{E}+03$ & 18.5 & $\mathbf{n} / \mathbf{a}$ & 21 & $n / a$ \\
\hline S95T000326 & & B & Boton-ICP-Acid Digest-Liquid & ug/mL & 98.2 & $5.00 \mathrm{E}-03$ & 63 & 54.3 & $5.87 \mathrm{E}+01$ & 14.7 & $\mathbf{n} / \mathbf{a}$ & 21 & $\mathrm{n} / \mathrm{a}$ \\
\hline S95T000326 & & B & Barium -ICP-Acid Digest-Liquid & $\mathrm{ug} / \mathrm{mL}$ & 97.6 & $0.00 \mathrm{E}+\infty 0$ & $<21.00$ & $<21.0$ & $n / a$ & n/a & $\mathbf{n} / \mathbf{a}$ & 21 & $n / 2$ \\
\hline \$95T000326 & & B & Bismuth -ICP-Acid Digest/Liq & $\mathrm{ug} / \mathrm{mL}$ & 101.6 & $1.00 \mathrm{E}-10$ & $<42.00$ & $<42.0$ & $n / \mathbf{a}$ & $\mathbf{n} / \mathbf{a}$ & $n / \mathbf{a}$ & 42 & $\mathrm{n} / \mathrm{a}$ \\
\hline$\$ 95$ T000326 & e & $\mathbf{B}$ & Calcium -ICP-Acid Digest-Liq & $\mathrm{ug} / \mathrm{mL}$ & 103.8 & $8.00 \mathrm{E}-03$ & $1.36 \mathrm{E}+02$ & 109 & $1.23 \mathrm{E}+02$ & 22 & $\mathbf{n} / \mathbf{2}$ & 42 & $n / a$ \\
\hline $595 \mathrm{~T} 000326$ & e & B & Ciromium -ICP-Acid Digest-Liq & $\mathrm{ug} / \mathrm{mL}$ & 102.4 & $0.00 \mathrm{E}+00$ & 35 & 29.7 & $3.24 \mathrm{E}+01$ & 16.1 & $n / 4$ & 4.2 & $n / 2$ \\
\hline $595 \mathrm{T000326}$ & & B & Iron -ICP-Acid Digest-Liguid & $\mathrm{ug} / \mathrm{mL}$ & 101.2 & $1.00 \mathrm{E}-03$ & $<21.00$ & $<21.0$ & $n / \mathbf{a}$ & $n / a$ & $n / \mathbf{a}$ & 21 & $n / 2$ \\
\hline $595 T 000326$ & e & B & Potassium -ICP-Acid Digest-Liq & $\mathrm{ug} / \mathrm{mL}$ & 97.6 & $-9.20 \mathrm{E}-02$ & $1.56 \mathrm{E}+03$ & 1260 & $1.41 \mathrm{E}+03$ & 21.3 & $n / \mathbf{a}$ & 210 & $\mathrm{n} / \mathbf{a}$ \\
\hline S95T000326 & & $\mathbf{B}$ & Lithium -ICP-Acid Digest-Liq & $4 \mathrm{~g} / \mathrm{mL}$ & 98.2 & $1.00 \mathrm{E}-03$ & $<4.200$ & $<4.20$ & $n / \mathbf{a}$ & $\mathbf{n} / \mathbf{k}$ & $\mathbf{n} / \mathbf{a}$ & 4.2 & $\mathrm{n} / \mathbf{a}$ \\
\hline $595 \mathrm{~T} 000326$ & c & B & Sodium -ICP-Acid Digest-Liquid & $u g / \mathrm{mL}$ & 98.2 & $6.00 \mathrm{E}-03$ & $1.10 \mathrm{E}+05$ & 92700 & $1.01 \mathrm{E}+05$ & 17.1 & $\mathbf{n} / \mathbf{a}$ & 42 & $\mathrm{n} / \mathbf{a}$ \\
\hline$\$ 95 T 000326$ & & B & Nickel -ICP-Acid Digest-Liquid & $u g / m L$ & 100.6 & $-6.00 \mathrm{E}-03$ & 25.6 & 22.1 & $2.39 \mathrm{E}+01$ & 14.7 & $\mathbf{n} / \mathbf{2}$ & 8.4 & $\mathbf{n} / \mathbf{a}$ \\
\hline S95T000326 & c & B & Phosphorus-ICP-Acid Adjust-Liq & $\mathrm{ug} / \mathrm{mL}$ & 100.4 & $-1.10 \mathrm{E}-02$ & $1.10 \mathrm{E}+03$ & 916 & $1.01 E+03$ & 18.3 & $n / \mathbf{a}$ & 84 & $\mathbf{n} / \mathbf{a}$ \\
\hline S95T000326 & e & B & Silicon -ICP-Acid Digest-Liq & $\mathrm{ug} / \mathrm{mL}$ & 93.2 & $1.90 \mathrm{E}-02$ & 83.6 & 70.3 & $7.70 \mathrm{E}+01$ & 17.3 & $\mathbf{n} / \mathbf{a}$ & 21 & $\mathbf{n} / \mathbf{a}$ \\
\hline $595 T 000326$ & & B & Uranium -ICP-Acid Digest-Liq & $\mathrm{ug} / \mathrm{mL}$ & 97.4 & $4.70 \mathrm{E}-02$ & $<2.10 e+02$ & $<210$ & $n / \mathbf{a}$ & $\mathrm{n} / \mathrm{a}$ & $\mathbf{n} / \mathbf{a}$ & 210 & $\mathbf{a} / \mathbf{2}$ \\
\hline
\end{tabular}




\begin{tabular}{|c|c|c|c|c|c|c|c|c|c|c|c|c|c|}
\hline$m$ & $50+a<r+$ & $\omega$ & $80 \div 5$ & $10+396 \div$ & $000 s \mathrm{~s}$ & $50+a z+1$ & $0<9 \mid t>$ & $8 \varepsilon \cdot 66$ & Tw/3n & Domen!I $x_{d} K_{q}-\mathrm{HO}$ & $\wedge$ & & ЋE000LS6S \\
\hline s'z & wara0 I & 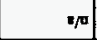 & $82 . L$ & warz' $\varepsilon$ & tЕE०० & $20-360^{\circ} \varepsilon$ & $60-300 \mathrm{I}$ & 89.96 & Tw/ & 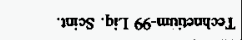 & a & & $0 \varepsilon \varepsilon 000156 \mathrm{~S}$ \\
\hline 9.62 & wanor's & $x / a$ & $\iota \mathfrak{\varepsilon t}$ & 10-806 I & $\mathfrak{n z \cdot 0}$ & to-a $L \cdot \mathrm{I}$ & $\tau-\infty 69 \varepsilon>$ & 6816 & $T^{p u r} \cdot \mathrm{O}^{n}$ & PNऽT प? & a & & o๕c000Ls6S \\
\hline 6.5 & s0-aहt $\angle$ & 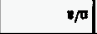 & $\tau \mathbf{R}$ & soraos 6 & 50-36t:8 & t0-asso- I & $5-90<\theta^{\prime} L>$ & 696 & Tw/:On & 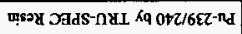 & a & ? & $0 \varepsilon \varepsilon 000 \perp \$ 6 S$ \\
\hline 16 & so-ąt $\iota$ & 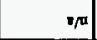 & $8 / \pi$ & $x p$ & s.ott.9> & s0- & $s-20<9<>$ & $\mathbf{x} / \mathbf{u}$ & Tw/:Dan & 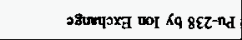 & a & & $0 \varepsilon \varepsilon 000 \perp S 6 S$ \\
\hline$\tau \mathbf{\varepsilon s \mathrm { I }}$ & है-700 I & 6.58 & $\mathbf{m}$ & $\pi$ & $\operatorname{tal}\left\langle 8^{\circ} t\right\rangle$ & $00265\langle>$ & $\forall=068^{\prime}\langle>$ & $6 r+16$ & Tw/on & 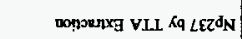 & a & & OEह000IS6S \\
\hline $90^{\circ} \mathrm{Z}$ & $50-3569$ & r'oss & $\varepsilon$ & $\varepsilon 0-\mathrm{azo} \varepsilon$ & $s 8200^{\circ} 0$ & $\varepsilon 0-a 6 t \varepsilon$ & $s=056.9>$ & $\infty \mathrm{I}$ & Tw/:0n & 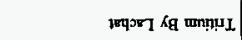 & $a$ & & ock000LS6S \\
\hline pu & graoo t & $\pi / 0$ & $\mathbf{0 / 0}$ & $\pi$ & 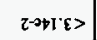 & $20-a b l \cdot \varepsilon>$ & $E-208 I^{\prime} \mid>$ & $\nabla v$ & Twingn & vao Kq ssi-umidoing & a & & 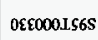 \\
\hline 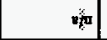 & $\varepsilon 0-900 \cdot t$ & $\nabla / 0$ & $8 / 0$ & 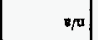 & $t \rightarrow 6 \tau^{2} \mathrm{~T}>$ & 20-9ह $1>$ & $\varepsilon-0, E E I>$ & $: \pi$ & Twion & vas Kq Hit-un!dorng & d & & oEع000LS6S \\
\hline $2 \mathrm{t} 0$ & ติ-400 I & 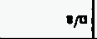 & 651 & $10+3<29$ & $\tau \in 9$ & $z z 9$ & $200208>$ & $\infty \mathbf{1}$ & Twhon & $\operatorname{VaD}$ Kq $\angle \varepsilon I-$-un!soo & a & & 0є5000L56S \\
\hline$p$ & $50-300 \mathrm{I}$ & 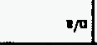 & $\nabla \pi$ & 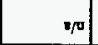 & $80000 \%$ & $\varepsilon 0-98 s^{\prime} z>$ & Feozess & toI & $\mathrm{T}^{\mathrm{w} / \mathrm{O} / \mathrm{n}}$ & VAD אq 09-1[ห⿻० & a & & $0 \varepsilon \varepsilon 000 L S 6 \mathrm{~S}$ \\
\hline s'ss & $60-8000 \mathrm{t}$ & $\div / 0$ & $\approx \pi$ & $\nabla$ & $+2608>$ & $50-2001>$ & 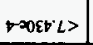 & $\pi$ & Tw/:On & 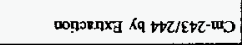 & a & & 0દE000LS6S \\
\hline$\varepsilon \cdot \mathrm{II}$ & ह0-a00 I & $n / u^{2}$ & $\nabla / 0$ & $\pi$ & $+2608>$ & $\varepsilon 0-200$ I $\mathrm{X}$ & F्OED'LC & to:z8 & Tw्w:On & tonjorsx] Kq lt $z$-wV & $a$ & & $0 \varepsilon \varepsilon 000 . L \$ 6 \mathrm{~S}$ \\
\hline+0 & $20-a 002$ & $\varepsilon 601$ & +0 & $10+350<$ & 6.89 & $z$ & $1-0,616$ & $\varepsilon$ soI & qurion & 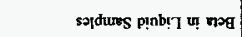 & a & & OEE000LLS6S \\
\hline 0005 & $20-9001$ & L:01 & $\nabla u$ & $*$ & $\varepsilon=\sigma|r\rangle$ & 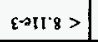 & $20-989 \cdot 8>$ & I6: 26 & Tum:On & 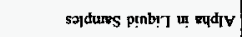 & a & & 0£ع000LS6S \\
\hline$v \pi$ & $20-200 \%$ & sit & 8.9 & $00+\mathrm{B} 6 \mathrm{~s}^{\prime} \mathrm{s}$ & $t s$ & $8 L \mathrm{~S}$ & $10-886^{\circ} \mathrm{T}$ & Е०६६ & $\mathrm{T}^{\mathrm{m} /} / \mathrm{gm}_{\mathrm{m}}$ & 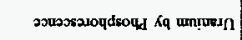 & a & & 0єع000LS6S \\
\hline$\pi \mu$ & $\tau \cdot t$ & $8 \pi$ & $v / u$ & $\nabla 0$ & $0 z \cdot b>$ & $002+>$ & $\varepsilon 0-\pi 00^{\circ} t$ & 66 & $T \mathbf{T} / 8 n$ & 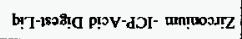 & g & & $9 z 5000 \perp 56 \mathrm{~S}$ \\
\hline $\mathbf{1} / \mathbf{u}$ & $\tau \bullet$ & $\pi$ & $1 / 0$ & $*$ & $o t b>$ & $00 z^{\circ}+>$ & $\varepsilon 0-\mathrm{a} 00^{\circ-}$ & $\tau$ ' & $\mathrm{T} \mathbf{w} / 3 \mathrm{sn}$ & 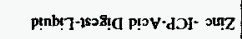 & g & & $9 \tau 8000 L 56 \mathrm{~S}$ \\
\hline $13016=21$ & $40.9=19$ & 3. & - 0137 & $4=$ & 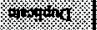 & 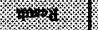 & स & $x+2=0$ & win & $4 x$ & $x$ & 6 & Hidurs. \\
\hline
\end{tabular}

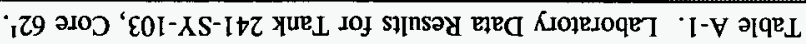




\begin{tabular}{|c|c|c|c|c|c|c|c|c|c|c|c|c|c|}
\hline $\mathbf{x} \mathbf{u}$ & 299 & $\mathrm{u}$ & 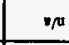 & 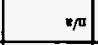 & TaT & 7a7 & $2+9 .<$ & S0'66 & $1 / 2 \mathrm{an}$ & 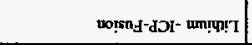 & $\mathrm{A}$ & & IZ1000Lt65s \\
\hline 9.29 & IO-A $\angle S L$ & 9.86 & $58: 8$ & 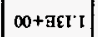 & $81 \cdot 1$ & 801 & {$[-\leadsto \mid<\in \varepsilon>$} & $\varsigma \varepsilon 6$ & 8 smon & p!̣os posssat!d jo rudV & $\mathrm{a}$ & & tz1000Lt6s \\
\hline$x / \pi$ & to-300'I & $\mathbf{w u}$ & $\angle 91$ & $20+392 \varepsilon$ & $9 \cdot z s \varepsilon$ & $20+386 z$ & 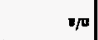 & $\mathbf{8} / 0$ & SId 3/molnor & 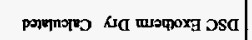 & & & $880000 \mathrm{LtbS}$ \\
\hline$\approx \pi$ & $20-300 \div$ & 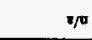 & 20 & $10+886 \varepsilon$ & $58.6 \mathrm{E}$ & 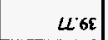 & $\mathbf{m}$ & $L<6$ & \$ & 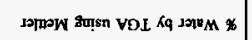 & & & $890000 \mathrm{~L}$. bs \\
\hline $8 \pi$ & $\quad 0 z z$ & $\mathbf{x} / \mathbf{u}$ & $8 E: 2$ & $60+301 \cdot z$ & $0 \varepsilon 12$ & $80+880 \cdot z$ & $*$ & $\mathbf{w} \mathbf{u}$ & $7 w / 8 n$ & 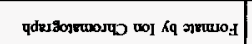 & $\wedge$ & & †E⿷000.LS6s \\
\hline$x \pi$ & $0 z z$ & $* \pi$ & $\angle S \cdot S$ & $20+\pi \angle E<L$ & $\angle S L$ & $20+39 \times 2$ & $\nabla / a$ & $\mathbf{u} \mathbf{u}$ & $\mathrm{T}^{\mathrm{w} / \mathrm{zn}}$ & 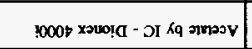 & $\wedge$ & & tEEO0OLS6S \\
\hline$\nabla v$ & $\mathfrak{n + a 8 9 - 1}$ & 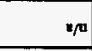 & $\pi$ & $\varepsilon 0+\pi 26 \varepsilon$ & 0000 & $\varepsilon 0+a \varepsilon 8^{\prime} \varepsilon$ & {$[=0008>$} & 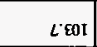 & $\mathbf{T} \mathbf{w} / \mathbf{z} \mathrm{n}$ & 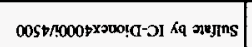 & 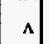 & & tec000.156s \\
\hline 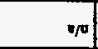 & $50+\pi 9 \tau \cdot \tau$ & $\pi / 0$ & III & $\mathrm{ED}+\mathrm{BI} / \mathrm{Z}$ & 0982 & $\varepsilon 0+3952$ & {$[-\infty 000.9>$} & 2196 & $T w / s n$ & 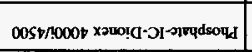 & $\wedge$ & & tEש000IS6S \\
\hline,$\pi$ & $9 z 1$ & 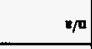 & $\pi$ & $\mathbf{m}$ & $z \rightarrow x:>$ & $z 0+\exists z \tau \varepsilon$ & $\tau=00009>$ & $98 \div 6$ & Twu/zn & OOS $\downarrow$ r & $\wedge$ & & tहع000LS6S \\
\hline $\mathbf{m}$ & 012 & $\nabla / u$ & 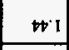 & $\varepsilon 0+z<r t$ & $\infty 02 t$ & $\varepsilon 0+a t t^{2} t$ & $I-\$ 000^{\circ} I>$ & $\tau$ ' & $T w / m$ & 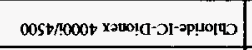 & $\wedge$ & & గEc000LS6S \\
\hline$v \mathrm{u}$ & $50+389^{\prime} \mathrm{I}$ & $\pi /$ & $6 \varepsilon^{\prime \prime} b$ & $50+309 \cdot \mathrm{T}$ & $00 \varepsilon 91$ & $50+895: 1$ & $1-00008>$ & $\varsigma$ ⿷⿻ol & $T w / 2 \mathrm{n}$ & 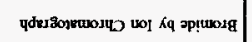 & $\wedge$ & & tEع000IS6S \\
\hline $\mathrm{n}, \mathrm{n}$ & $\varepsilon 0-800 \mathrm{I}$ & $\star \pi$ & $3 / \mathbf{u}$ & $\nabla / 0$ & $t-0009$ & $10-988^{\prime} t>$ & $50069 \mathrm{~s}>$ & $15: 26$ & Turp:?n| & 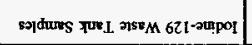 & $\wedge$ & & 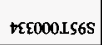 \\
\hline $\mathbf{0} \mathbf{u}$ & $6 \varepsilon 6 \varepsilon$ & $x / u$ & i6t & $10+881 / 2$ & 8.82 & $t * 9$ & $\tau=006\{\varepsilon>$ & z zoo & $T^{m} / 8 n$ & 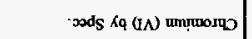 & $\Lambda$ & & t£ع000LS6S \\
\hline 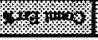 & 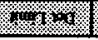 & 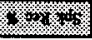 & Toitix & 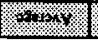 & 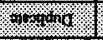 & 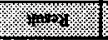 & 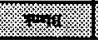 & 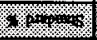 & 10 & sitim & 6 & 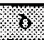 & ind on: \\
\hline
\end{tabular}

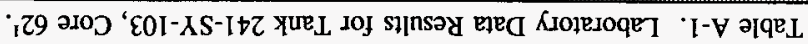


Table A-1. Laboratory Data Results for Tank 241-SY-103, Core $62^{1}$.

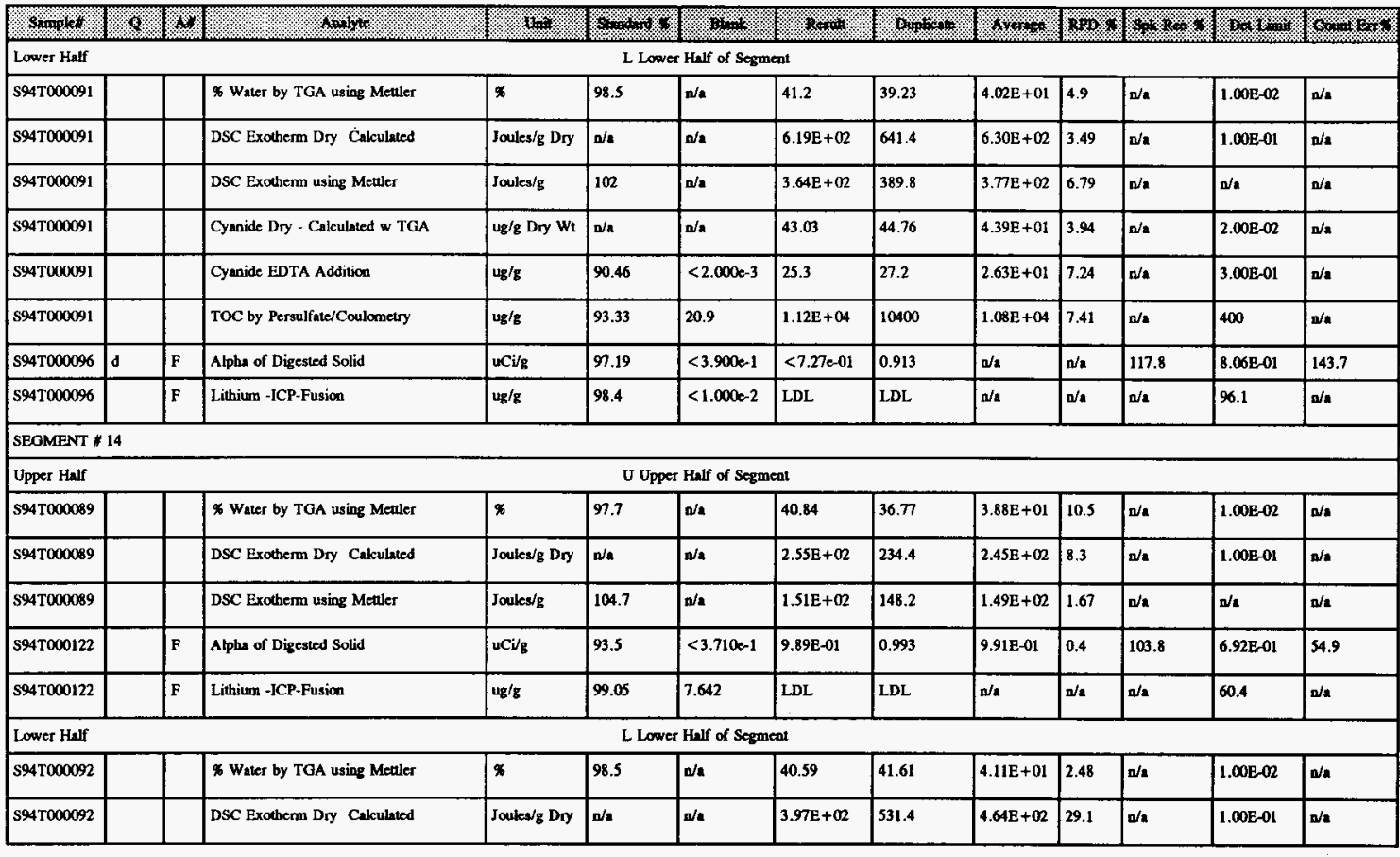


Table A-1. Laboratory Data Results for Tank 241-SY-103, Core $62^{1}$.

\begin{tabular}{|c|c|c|c|c|c|c|c|c|c|c|c|c|c|}
\hline sanplet & $\alpha$ & x. & 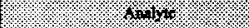 & xing & - & (1) & $\mathrm{R}+\mathrm{m}$ & 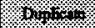 & 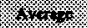 & (2) & \% & 6ts & song \\
\hline S94 T000092 & & & DSC Exotherm using Mettler & Jouks/g & 102 & $\mathbf{n} / \mathbf{a}$ & $2.36 \mathrm{E}+02$ & 310.3 & $2.73 \mathrm{E}+02$ & 27.4 & $\mathbf{n} / \mathbf{a}$ & $\mathrm{n} / \mathbf{a}$ & $\mathrm{n} / \mathbf{2}$ \\
\hline \$94T000092 & & & Cyanide Dry - Calculated w TGA & ug/s Dry wt & $\mathrm{n} / \mathrm{a}$ & $n / \mathbf{2}$ & $1.53 \mathrm{E}+02$ & 161.5 & $1.57 \mathrm{E}+02$ & 5.27 & $\mathbf{a} / \mathbf{a}$ & $2.00 \mathrm{E}-02$ & $n / m$ \\
\hline s94T000092 & c & & Cyanide EDTA Addition & $\mathrm{ug} / \mathrm{g}$ & 90.46 & $<1.000 \mathrm{k}-1$ & 91 & 94.3 & $9.27 \mathrm{E}+01$ & 3.56 & 82.8 & 6.64 & n/a \\
\hline $\mathrm{S} 94 \mathrm{~T} 000092$ & e & & TOC by Persulfate/Coulometry & ug $/ \mathrm{g}$ & 93.33 & 20.9 & $6.48 \mathrm{E}+03$ & 14100 & $1.03 \mathrm{E}+04$ & 74.1 & $\mathbf{n} / \mathbf{a}$ & 400 & $n / \mathbf{a}$ \\
\hline S94T000097 & & $\mathbf{F}$ & A lpha of Digested Solid & $\mathrm{uCi} / \mathbf{g}$ & 94.76 & $<3.180 \mathrm{e}-1$ & 1.43 & 1.65 & $1.54 \mathrm{E}+\infty 0$ & 14.3 & 99.3 & $5.67 \mathrm{E}-01$ & 36.1 \\
\hline S94T000097 & & $\mathbf{F}$ & Lithium -ICP-Fusion & $u g / g$ & 98.4 & $<1.000 \mathrm{k}-2$ & LDL & LDL & $n^{\prime} / n$ & $\mathbf{n} / \mathbf{a}$ & $n / 2$ & 58.6 & $n / \mathbf{a}$ \\
\hline
\end{tabular}

心 
Table A-1. Laboratory Data Results for Tank 241-SY-103, Core 62'.

\begin{tabular}{|c|c|c|c|c|c|c|c|c|c|c|c|c|c|}
\hline sunplet & 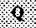 & \% & Wow & Kin & Nox 10 & 101 & Ken & 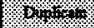 & $1 \%$ & 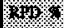 & 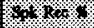 & 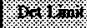 & $8,10 \%$ \\
\hline \multicolumn{14}{|c|}{ SEGMENT \# 15} \\
\hline \multicolumn{6}{|c|}{ SEGMENT PORTION } & \multicolumn{8}{|l|}{ Liner Liquid } \\
\hline$\$ 95 T 000262$ & & & Bullk Density of Sample & $\mathrm{g} / \mathrm{mL}$ & $n / \mathbf{a}$ & $\mathbf{n} / \mathbf{a}$ & 1.16 & $\mathbf{n} / \mathbf{a}$ & $\mathrm{a} / \mathbf{n}$ & $\mathbf{a} / \mathbf{a}$ & $\mathbf{n} / \mathbf{a}$ & $5.00 \mathrm{E}-01$ & $\mathbf{n} / \mathbf{a}$ \\
\hline S95T000285 & & & Tat. Organic Cathon by Coul. & ug/mL & 99.67 & $<5.000$ & $3.81 E+03$ & 3960 & $3.88 \mathrm{E}+03$ & 3.86 & n/a & 105 & n/a \\
\hline S95T000285 & & & \% Water by TCA using Mettler & ๓ & 99.34 & $n / \mathbf{a}$ & 75.35 & 74.73 & $7.50 \mathrm{E}+01$ & 0.83 & $\mathbf{n} / \mathbf{a}$ & $n / \mathbf{a}$ & $a^{\prime} n$ \\
\hline \$95T000285 & & & pH Direct & pH & 99.46 & $n / a$ & 13.5 & $n / \mathbf{a}$ & a/a & $\mathrm{n} / \mathbf{a}$ & $\mathbf{n} / \mathbf{a}$ & $1.00 \mathrm{E}-02$ & $\mathrm{n} / \mathbf{s}$ \\
\hline S95T000285 & & & DSC Exotherm using Metuler & Joules/z & 107.2 & $n / \mathbf{a}$ & $0.00 \mathrm{E}+\infty$ & 0 & $0.00 \mathrm{E}+00$ & $n / \mathbf{2}$ & $\mathbf{n} / \mathbf{a}$ & $\mathbf{n} / \mathbf{a}$ & $n / \mathbf{a}$ \\
\hline S95T000327 & & $\mathrm{B}$ & Aluminium -ICP-Acid Digest-Liq & $\mathbf{u g} / \mathrm{mL}$ & 99.6 & $-6.00 \mathrm{E}-03$ & $3.08 \mathrm{E}+03$ & 3060 & $3.07 \mathrm{E}+03$ & 0.65 & $\mathbf{a} / \mathbf{a}$ & 21 & $n / a$ \\
\hline \$95T000327 & & B & Boron-ICP-Acid Digest-Liquid & $\mathrm{ug} / \mathrm{mL}$ & 98.2 & $5.00 \mathrm{E}-03$ & 33.2 & 34.4 & 3.38E+01 & 3.55 & $\mathbf{n} / \mathbf{a}$ & 21 & $n / n$ \\
\hline \$95T000327 & & B & Barium -ICP-Acid Digest-Liquid & $u \mathrm{~g} / \mathrm{mL}$ & 97.6 & $0.00 \mathrm{E}+00$ & $<21.00$ & $<21.0$ & $\mathbf{n} / \mathbf{a}$ & $\mathbf{n} / \mathbf{a}$ & $\mathrm{n} / \mathbf{\imath}$ & 21 & $n / \mathbf{a}$ \\
\hline S95T000327 & & B & Bismuth -ICP-Acid Digest/Liq & $u g / m L$ & 101.6 & $1.00 \mathrm{E}-02$ & $<42.00$ & $<42.0$ & $n / \mathbf{a}$ & $\alpha / a$ & $n / \mathbf{a}$ & 42 & $n / 2$ \\
\hline s95T000327 & & B & Calcium -ICP-Acid Digest-Liq & ug $/ \mathrm{mL}$ & 103.8 & $8.00 \mathrm{E}-03$ & 75.2 & 86.4 & $8.08 \mathrm{E}+01$ & 13.9 & $\mathbf{a} / \mathbf{a}$ & 42 & $\mathbf{n} / \mathbf{\imath}$ \\
\hline S95T000327 & & B & Chromiun -ICP-Acid Digest-Liq & $u g / m L$ & 102.4 & $0.00 \mathrm{E}+\infty$ & 5.49 & 5.24 & $5.37 \mathrm{E}+00$ & 4.66 & $n / \mathfrak{a}$ & 4.2 & $\mathbf{n} / \mathbf{a}$ \\
\hline S95T000327 & & B & Iron -ICP-Acid Digest-Liquid & $\mathrm{ug} / \mathrm{ml}$ & 101.2 & $1.00 \mathrm{E}-03$ & $<21.00$ & $<21.0$ & $n / a$ & $n / a$ & $n / a$ & 21 & $n / a$ \\
\hline S95T000327 & & B & Potussium -ICP-Acid Digest-Liq & $\operatorname{ug} / \mathrm{mL}$ & 97.6 & $-9.20 \mathrm{E}-02$ & $1.20 \mathrm{E}+\infty 3$ & 1190 & $1.20 \mathrm{E}+03$ & 10 & $n / \mathbf{a}$ & 210 & $n / \mathbf{a}$ \\
\hline S95T000327 & & B & Lithium -ICP-Acid Digest-Liq & ue/mL & 98.2 & $1.00 \mathrm{E}-03$ & 69.1 & 68.7 & $6.89 \mathrm{E}+01$ & 0.58 & $n / \mathbf{a}$ & 4.2 & $n / 2$ \\
\hline S95T000327 & & B & Sodium -ICP-Acid Digest-Liquid & $\mathrm{ug} / \mathrm{mL}$ & 98.2 & $6.00 \mathrm{E}-03$ & $7.34 \mathrm{E}+04$ & 73000 & $7.32 \mathrm{E}+04$ & 0.55 & $\mathbf{n} / \mathbf{a}$ & 42 & $n / n$ \\
\hline S95T000327 & & B & Nickel -ICP-Acid Digest-Liquid & ug $/ \mathrm{mL}$ & 100.6 & $-6.00 \mathrm{E}-03$ & 26.6 & 26.1 & $2.64 \mathrm{E}+01$ & 1.9 & $n / a$ & 8.4 & $n / n$ \\
\hline
\end{tabular}


Table A-1. Laboratory Data Results for Tank 241-SY-103, Core $62^{1}$.

\begin{tabular}{|c|c|c|c|c|c|c|c|c|c|c|c|c|c|}
\hline Sintot & 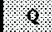 & W & 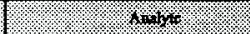 & 10 & 1.n. & 12 & $\mathrm{x}=\mathrm{x}_{\mathrm{x}}$ & 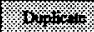 & 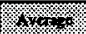 & 640 & mox & $3 \times 1 \times$ & $800+4 \%$ \\
\hline S95T000327 & & B & Phosptorus-ICP-Acid Adjust-Liq & ug/mL & 100.4 & $-1.10 \mathrm{E}-02$ & $6.35 \mathrm{E}+02$ & 640 & $6.38 \mathrm{E}+02$ & 0.78 & $n / a$ & 84 & $n / a$ \\
\hline S95T000327 & & B & Silicon -ICP-Acid Digest-Liq & ug $/ \mathrm{ml}$ & 93.2 & $1.90 \mathrm{E}-02$ & 84.1 & 88.9 & $8.65 \mathrm{E}+01$ & 5.55 & $\mathbf{n} / \mathbf{a}$ & 21 & $\mathrm{n} / \mathrm{a}$ \\
\hline S95T000327 & & B & Uranium -ICP-Acid Digest-Liq & ug $/ \mathrm{ml}$ & 97.4 & $4.70 E-02$ & $<2.10 e+02$ & $<210$ & $n / 4$ & $a / a$ & $n / \mathbf{n}$ & 210 & $\mathbf{a} / \mathbf{a}$ \\
\hline$\$ 95 T 000327$ & & B & Zinc-ICP-Acid Digest-Liquid & $\mathrm{ug} / \mathrm{mL}$ & 103.2 & $-1.00 \mathrm{E}-03$ & $<4.200$ & $<4.20$ & $a / n$ & $\mathrm{~d} / \mathrm{k}$ & $n / \mathbf{a}$ & 4.2 & $\mathrm{n} / \mathrm{a}$ \\
\hline S95T000327 & & B & Zirconium -ICP-Acid Digest-Liq & $\mathrm{ug} / \mathrm{mL}$ & 99 & $4.00 \mathrm{E}-03$ & $<4.200$ & $<4.20$ & $n / \mathbf{a}$ & n/a & $n / a$ & 4.2 & $n / 2$ \\
\hline S95T000331 & e & D & Uranium by Ptosphorescence & $\operatorname{ug} / \mathrm{mL}$ & 93.03 & $1.98 \mathrm{E}-01$ & 4.64 & 5.82 & $5.23 \mathrm{E}+\infty$ & 22.6 & 116 & $3.00 \mathrm{E}-02$ & $n / a$ \\
\hline S95T000331 & & D & Alpha in Liquid Samples & uCi/mL & 93.91 & $<8.68 \mathrm{e}-02$ & $<4.61 \mathrm{e}-3$ & $<6.94 \mathrm{e}-3$ & $n / 2$ & $\mathrm{n} / \mathrm{a}$ & 98.00 & $1.06 c-02$ & 196.0 \\
\hline S95T000330 & & D & Alpha in Liquid Samples & $\mathrm{uCi} / \mathrm{mL}$ & 93.91 & $<8.68 \mathrm{e}-02$ & $<8.11 \mathrm{e}-3$ & $<5.19-3$ & $\mathbf{a} / \mathbf{a}$ & n/a & 107.7 & $1.06 \mathrm{e}-02$ & 500.0 \\
\hline s95T000331 & & D & Beta in Liquid Samples & $\mathrm{uCi} / \mathrm{mL}$ & 105.3 & $<1.910 \mathrm{k}-1$ & $1.10 \mathrm{E}+02$ & 115 & $1.13 \mathrm{E}+02$ & 4.44 & 109 & $2.40 \mathrm{E}-02$ & 0.3 \\
\hline S95T000331 & & $\mathbf{D}$ & Am-241 by Extraction & $\mathrm{uCi} / \mathrm{mL}$ & 82.41 & $<7.430 e-4$ & $<1.12 \mathrm{e}-03$ & $<1.83 \mathrm{e}-3$ & $\mathrm{n} / \mathrm{a}$ & $n / m$ & $n / h$ & $1.00 \mathrm{E}-03$ & 20 \\
\hline S95T000331 & & D & Cm-243/244 by Exunction & $\mathrm{uCi} / \mathrm{mL}$ & $n / \mathbf{a}$ & $<7.430 \mathrm{k}-4$ & $<1.12=03$ & $<1.83 e-3$ & $n / n$ & $n / m$ & $\mathbf{a} / \mathbf{a}$ & $1.00 \mathrm{E}-03$ & 74.2 \\
\hline S95T000331 & & D & Cobslt-60 by GEA & $\mathrm{uCi} / \mathbf{m L}$ & 104 & $<5.3200-4$ & $<4.76 \mathrm{e}-03$ & $<4.720-3$ & $n / 2$ & $n / a$ & $n / \mathbf{a}$ & $1.00 \mathrm{E}-03$ & niga \\
\hline \$95T000331 & & D & Cesium- 137 by GEA & $\mathrm{wCi} / \mathbf{m L}$ & 100 & $<8.020=-4$ & $1.04 \mathrm{E}+02$ & 104 & $1.04 \mathrm{E}+02$ & 0 & $\mathbf{n} / \mathbf{a}$ & $1.00 \mathrm{E}-03$ & 0.1 \\
\hline S95T000331 & & D & Europium-154 by GEA & $\mathrm{uCv} / \mathrm{mL}$ & $n / \mathbf{a}$ & $<1.330 \mathrm{k}-3$ & $<2.32 e-02$ & $<2.28 \mathrm{e}-2$ & $\mathrm{n} / \mathbf{a}$ & $n / a$ & $n / a$ & $1.00 \mathrm{E}-103$ & nita \\
\hline s95T000331 & & D & Europium- 155 by GEA & uCi/ml. & $\mathbf{n} / \mathbf{a}$ & $<1.180<-3$ & $<4.08 \mathrm{e}-02$ & $<4.06<-2$ & $n / 2$ & $\mathrm{~d} / \mathbf{a}$ & $n / a$ & $1.00 \mathrm{E}-03$ & min \\
\hline S95T000331 & c, e & D & Tritium By Lachat & uCi/mL & 100 & $<6.9500-5$ & $6.89 \mathrm{E}-03$ & 0.00198 & $4.43 \mathrm{E}-03$ & 111 & 20.9 & $6.95 \mathrm{E}-05$ & 1.45 \\
\hline S95T000331 & & D & Np237 by TTA Extraction & $\mathbf{u C i} / \mathbf{m L}$ & 91.19 & $<7.890<-4$ & $<6.53 \circ-04$ & 0.000879 & $n / a$ & $\mathrm{n} / \mathbf{a}$ & 87.6 & $1.00 \mathrm{E}-03$ & 217.8 \\
\hline S95T000331 & & D & Pu-238 by lon Exchange & $\mathrm{uCi} / \mathrm{mL}$ & $n / a$ & $<7.670 \mathrm{e}-5$ & $<6.57 e-05$ & $<6.10 \mathrm{e}-5$ & $\mathrm{n} / \mathrm{a}$ & $\mathrm{n} / \mathrm{a}$ & $n / a$ & $6.57 \mathrm{E}-05$ & 100 \\
\hline
\end{tabular}


Table A-1. Laboratory Data Results for Tank 241-SY-103, Core $62^{1}$.

\begin{tabular}{|c|c|c|c|c|c|c|c|c|c|c|c|c|c|}
\hline Sumplef & 9 & 1 & 10 & 110 & 8401 & 10 & $\mathrm{kem}$ & on & 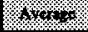 & Xx & 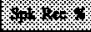 & ox $\times$ wh & $8 \%+17$ \\
\hline S95T000331 & & D & Pu-239/240 by TRU-SPEC Resin & $\mathbf{u C i} / \mathrm{mL}$ & 96.9 & $<7.670 \mathrm{e}-5$ & $<6.57 \mathrm{e}-05$ & $<6.10 \mathrm{e}-5$ & $n / s$ & $n / \mathbf{a}$ & $\mathbf{n} / \mathbf{a}$ & $6.57 \mathrm{E}-05$ & 100 \\
\hline S95T000331 & & $\mathrm{D}$ & Strontium-89/90 High Level & $\mathrm{uCi} / \mathrm{mL}$ & 91.89 & $<3.690 \mathrm{c}-2$ & $3.25 \mathrm{E}-01$ & 0.318 & $3.22 \mathrm{E}-01$ & 2.18 & $\mathbf{n} / \mathbf{a}$ & $5.20 \mathrm{E}-02$ & 19.5 \\
\hline S95T000331 & & D & Technetium-99 Liq, Seint. & uCímL & 96.68 & $1.00 \mathrm{E}-03$ & $4.28 \mathrm{E}-02$ & 0.039 & $4.09 \mathrm{E}-02$ & 9.29 & $a / a$ & $1.00 \mathrm{E}-03$ & 2.03 \\
\hline s95 T000335 & & $\mathrm{v}$ & OH- by Pot. Titration & $\operatorname{ug} / \mathrm{mL}$ & 99.38 & $<4167.0$ & $1.30 \mathrm{E}+04$ & 12700 & $1.28 \mathrm{E}+04$ & 2.33 & $a / a$ & $4.17 \mathrm{E}+03$ & $\mathrm{n} / \mathrm{a}$ \\
\hline s95T000335 & e & $\mathrm{v}$ & Chromium (VI) by Spec. & $u_{\mathrm{g}} / \mathrm{mL}$ & 102.2 & $<3.900<-2$ & 8.18 & 11 & $9.59 \mathrm{E}+00$ & 29.4 & $\mathbf{n} / \mathbf{2}$ & 3.939 & $n / a$ \\
\hline s95T000335 & & $v$ & Iodine-129 Waste Tank Samples & $\mathrm{uCi} / \mathrm{mL}$ & 92.51 & $<5.640 c-4$ & $<4.58 \mathrm{e}-04$ & $<5.82 \mathrm{e}-4$ & $n / a$ & $n / 2$ & $\mathbf{n} / \mathbf{a}$ & $1,00 \mathrm{E}-03$ & $n / a$ \\
\hline \$95T000335 & & $\mathrm{v}$ & Bromide by Ion Chromatograph & $\operatorname{ug} / \mathrm{mL}$ & 103.5 & $<8,000 \mathrm{k}-1$ & $1.76 \mathrm{E}+04$ & 17500 & $1.76 \mathrm{E}+04$ & 0.57 & $\mathbf{n} / \mathbf{a}$ & $1.69 \mathrm{E}+03$ & $n / 2$ \\
\hline s95T000335 & & $\mathbf{v}$ & Chloride-IC-Dionex $4000 \mathrm{j} / 4500$ & ug $/ \mathrm{mL}$ & 103.2 & $<1.000 \mathrm{e}-1$ & $3.86 \mathrm{E}+03$ & 3880 & $3.87 \mathrm{E}+03$ & 0.52 & $n / n$ & 210 & $a / 2$ \\
\hline \$95T000335 & & $\mathrm{v}$ & Fluoride-IC-Dionex $4000 \mathrm{i} / 4500$ & $\mathrm{ug} / \mathrm{mL}$ & 97.86 & $<6.000 k-2$ & $<1.26 e+02$ & $<1.26 \mathrm{e} 2$ & $\mathbf{n} / \mathbf{a}$ & $n / \mathbf{n}$ & $\mathbf{n} / \mathbf{m}$ & 126 & a/a \\
\hline \$95T000335 & & $\mathbf{v}$ & Nitrite-IC - Dionex $4000 \mathrm{i} / 4500$ & $\log / \mathrm{mL}$ & 97.59 & $<8.000 \mathrm{e}-1$ & $4.15 \mathrm{E}+04$ & 41400 & $4.14 \mathrm{E}+04$ & 0.24 & $n / a$ & $1.68 \mathrm{E}+03$ & $n / \mathbf{a}$ \\
\hline S95T000335 & & $\mathbf{v}$ & Nitrate-IC - Dionex $4000 \mathrm{i} / 4500$ & $\operatorname{ug} / \mathrm{mL}$ & 102.2 & $<1,(\mathbf{0 0})$ & $5.93 \mathrm{E}+04$ & 59200 & $5.92 \mathrm{E}+04$ & 0.17 & $n / \mathbf{a}$ & $2.10 \mathrm{E}+03$ & $n / 2$ \\
\hline \$95T000335 & & $\mathbf{v}$ & Oxalate by IC - Dionex 4000 i & $\log / \mathrm{mL}$ & 92.87 & $<5.000 \mathrm{e}-1$ & $<1.05 e+03$ & $<1.0 \mathrm{se} 3$ & $n / \mathbf{a}$ & $n / a$ & $n / a$ & $1.05 \mathrm{E}+03$ & $\pi / a$ \\
\hline s95T000335 & & $\mathrm{v}$ & Phosphate-IC-Diocex 4000i/4500 & $\mathrm{ug} / \mathrm{mL}$ & 96.12 & $<6.000 \mathrm{c}-1$ & $1.68 \mathrm{E}+03$ & 1720 & $1.70 \mathrm{E}+\infty 3$ & 2.35 & $\mathbf{n} / \mathbf{a}$ & $1.26 \mathrm{E}+03$ & $n / a$ \\
\hline S95T000335 & & $\mathbf{v}$ & Sulfate by IC-Dionex $4000 \mathrm{i} / 4500$ & $\operatorname{ug} / \mathrm{mL}$ & 103.7 & $<8.000 \mathrm{e}-1$ & $2.55 \mathrm{E}+03$ & 2570 & $2.56 \mathrm{E}+03$ & 0.78 & $n / \mathbf{a}$ & $1.68 \mathrm{E}+03$ & $n / a$ \\
\hline \$95T000335 & & $\mathrm{v}$ & Acetate by IC - Dicnex 4000 i & ug $/ \mathrm{mL}$ & $\mathbf{n} / \mathbf{a}$ & $\mathbf{n} / \mathbf{a}$ & $7.05 E+02$ & 692 & $6.99 \mathrm{E}+02$ & 1.86 & $\mathbf{D} / \mathbf{a}$ & 220 & $\mathrm{a} / \mathbf{a}$ \\
\hline S95T000335 & & $\mathrm{v}$ & Formale by lon Chromatograph & $\mathrm{ug} / \mathrm{ml}$ & $n / a$ & $n / a$ & $2.09 \mathrm{E}+03$ & 2010 & $2.05 \mathrm{E}+03$ & 3.9 & $\mathrm{n} / \mathrm{h}$ & 220 & $n / n$ \\
\hline \multicolumn{14}{|l|}{ Lower Half } \\
\hline S94T000093 & & & \% Water by TGA using Meuler & $\%$ & 100.1 & $n / 6$ & 68.87 & 68.64 & $6.88 \mathrm{E}+01$ & 0.33 & $\mathrm{n} / \mathrm{a}$ & $1.00 \mathrm{E}-02$ & $\mathfrak{w} / \mathfrak{n}$ \\
\hline
\end{tabular}


Table A-1. Laboratory Data Results for Tank 241-SY-103, Core 62 ${ }^{1}$.

\begin{tabular}{|c|c|c|c|c|c|c|c|c|c|c|c|c|c|}
\hline stimplot & 0 & $x$ & 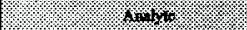 & 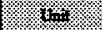 & 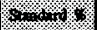 & $3 \% * 2:$ & $x=11$ & 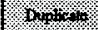 & Shr... & 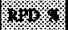 & $13 \times<0<0$ & 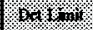 & 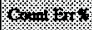 \\
\hline S94T000093 & & & DSC Exotherm Dry Calculated & Joules/g Dry & $\mathrm{n} / \mathbf{a}$ & $\mathrm{a} / \mathrm{a}$ & $0.00 \mathrm{E}+\infty$ & 0 & $0.00 \mathrm{E}+\infty$ & $n / \mathbf{a}$ & $\mathbf{n} / \mathbf{a}$ & $\mathrm{n} / \mathbf{a}$ & $\mathbf{a} / \mathbf{a}$ \\
\hline \$94T000093 & & & DSC Exotherm using Metuler & Joules/g & 102.6 & $n / \mathbf{n}$ & $0.00 E+\infty 0$ & 10 & $0.00 \mathrm{E}+\infty$ & $\mathrm{n} / \mathrm{a}$ & $\mathbf{n} / \mathbf{a}$ & $\mathbf{n} / \mathbf{2}$ & $\mathrm{n} / \mathbf{2}$ \\
\hline \$94T000098 & & $\mathrm{F}$ & Alpha of Digested Solid & uCi/g & 94.76 & $<3.1800-1$ & $5.09 \mathrm{E}-01$ & $<4.886-1$ & $n / \mathbf{s}$ & $\mathrm{n} / \mathbf{a}$ & 97.1 & $6.08 \mathrm{E}-01$ & 89.5 \\
\hline $594 \mathrm{~T} 000098$ & & $\mathrm{~F}$ & Lithium -ICP-Fusion & $\mathrm{ug} / \mathrm{g}$ & 104 & $<1.000 k-2$ & $2.08 \mathrm{E}+03$ & 1810 & $1.94 \mathrm{E}+03$ & 13.9 & $\mathbf{a} / \mathbf{a}$ & 120 & $\mathrm{n} / \mathbf{a}$ \\
\hline S95T000157 & & w & Bromide by Ion Chromelograph & $\mathrm{ug} / \mathrm{g}$ & 100.3 & $<1.000$ & $2.44 \mathrm{E}+04$ & 24000 & $2.42 \mathrm{E}+04$ & 1.65 & 97 & 1 & $\mathrm{n} / \mathbf{a}$ \\
\hline S94T000104 & & & * Water by TGA using Metter & x & 99 & $n / \mathbf{a}$ & 74.74 & 75.39 & $7.51 \mathrm{E}+01$ & 0.87 & $\mathbf{n} / \mathbf{2}$ & $1.00 \mathrm{E}-22$ & $\mathbf{n} / \mathbf{2}$ \\
\hline S94 T000104 & & & DSC Exotherm using Mettiler & Joules/g & 100.2 & $\mathrm{a} / \mathbf{a}$ & $1.56 \mathrm{E}+02$ & 205.3 & $1.81 \mathrm{E}+02$ & 27.4 & $\mathbf{n} / \mathbf{a}$ & $\mathbf{n} / \mathbf{2}$ & $n / 2$ \\
\hline $594 \mathrm{~T} 000104$ & & & Sulfate by IC-Diouex $4000 / 4500$ & ug/mL & $\mathbf{n} / \mathbf{a}$ & $\mathrm{n} / \mathrm{a}$ & $a_{i=a}$ & $n_{i}$ & $\mathbf{n} / \mathbf{a}$ & $\mathrm{n} / \mathbf{a}$ & $\mathbf{n} / \mathbf{n}$ & $9.99 \mathrm{E}-01$ & $\mathrm{n} / \mathrm{a}$ \\
\hline $594 \mathrm{~T} 000104$ & & & Phosphate-IC-Dionex 4000i/4500 & $\mathbf{w} / \mathbf{m L}$ & $\mathbf{n} / \mathbf{a}$ & $\mathrm{n} / \mathbf{a}$ & nia & na & $\mathbf{n} / \mathbf{a}$ & $\mathrm{n} / \mathbf{n}$ & $\mathbf{n} / \mathbf{n}$ & $9.99 \mathrm{E}-01$ & $\mathrm{n} / \mathbf{2}$ \\
\hline S94T000104 & & & Nitrate-IC - Dionex 4000i/4500 & $\mathrm{ug} / \mathrm{mL}$ & $\mathbf{n} / \mathbf{s}$ & $\mathrm{n} / \mathbf{2}$ & nia & $a_{z a}^{*}$ & $\mathrm{n} / \mathbf{a}$ & $\mathrm{n} / \mathbf{a}$ & $\mathbf{n} / \mathbf{a}$ & $9.99 \mathrm{E}-01$ & $n / 2$ \\
\hline \$94T000104 & & & Nitrite-IC - Disnex 40000 i/4500 & ug/mL & $\mathbf{n} / \mathbf{L}$ & $\mathrm{a} / \mathbf{2}$ & nats & $\log _{\mathbf{a}}$ & $n / \mathbf{a}$ & $\mathbf{a} / \mathbf{a}$ & $\mathrm{n} / \mathbf{a}$ & $9.99 \mathrm{E}-01$ & $\mathrm{n} / \mathrm{s}$ \\
\hline S94T000104 & & & Fluoride-IC-Dionex 4000 i/4500 & $\mathrm{ug} / \mathrm{mL}$ & $\mathbf{n} / \mathbf{n}$ & $\mathbf{n} / \mathbf{a}$ & 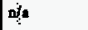 & atas & $\mathbf{n} / \mathbf{a}$ & $\mathrm{n} / \mathbf{a}$ & $n / \mathbf{n}$ & $1.00 \mathrm{E}-01$ & $\mathbf{n} / \mathbf{a}$ \\
\hline$\$ 94 \mathrm{~T} 0 \times 0104$ & & & Chloride-IC-Dionex 4000i/4500 & $\mathrm{ug} / \mathrm{mL}$ & $\mathbf{n} / \mathbf{n}$ & $\mathrm{n} / \mathbf{2}$ & nas & nala & $\mathbf{n} / \mathbf{a}$ & $n / 2$ & $\mathbf{n} / \mathbf{a}$ & $2.00 \mathrm{E}-01$ & a/a \\
\hline $594 \mathrm{~T} 000104$ & & & Bromide by loo Chromulograph & ug/mL & 103 & $<1.000$ & $1.93 \mathrm{E}+04$ & 18900 & $1.91 \mathrm{E}+04$ & 2.09 & 98.6 & I & $\mathrm{n} / \mathbf{2}$ \\
\hline 594000113 & & D & Lithium-ICP-Acid Dil. & $\mathrm{ug} / \mathrm{mL}$ & 100.6 & $0.00 \mathrm{E}+00$ & LDL & LDL & $\mathbf{n} / \mathbf{a}$ & $\mathrm{n} / \mathrm{a}$ & $\mathbf{n} / \mathbf{n}$ & 11 & $\mathrm{n} / \mathrm{a}$ \\
\hline S95T000156 & & A & Lithium -ICP-Acid Digest & Lug/g & 96.6 & $0.00 \mathrm{E}+00$ & $1.92 \mathrm{E}+02$ & 193 & $1.93 \mathrm{E}+02$ & 0.52 & $\mathbf{n} / \mathbf{n}$ & 2.19 & $\mathrm{n} / \mathbf{2}$ \\
\hline \multicolumn{14}{|c|}{ SEGMENT \# 10-14 } \\
\hline \multicolumn{14}{|c|}{ Stratumen "D" Solids Composite } \\
\hline Sampleff & Q & A\# & Analyue & Unit & Standard \$ & Blenk & Result & Duplicate & Average & RPD $\%$ & Spk Rec $\%$ & Det Limit & Count Er \% \\
\hline
\end{tabular}


Table A-1. Laboratory Data Results for Tank 241-SY-103, Core $62^{1}$.

\begin{tabular}{|c|c|c|c|c|c|c|c|c|c|c|c|c|c|}
\hline sanplef & 8 & $\alpha$ & 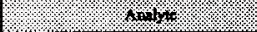 & $y=$ & $1401.1 \%$ & 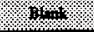 & (1) & (1) & 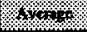 & \%19 & 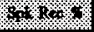 & No. mu & H.14 \\
\hline s94T000271 & & & Bulk Density of Sample & $\mathrm{g} / \mathrm{mL}$ & $n / a$ & $\mathbf{n} / \mathbf{a}$ & 1.57 & $\mathrm{n} / \mathrm{a}$ & $\mathbf{n} / \mathbf{a}$ & $\mathrm{n} / \mathrm{a}$ & $n / \mathbf{a}$ & $5.00 \mathrm{E}-01$ & $n / a$ \\
\hline \$94T000275 & & & * Water by TGA on Perkin Ehmer & * & 98.28 & $n / \mathbf{a}$ & 32.13 & 33.85 & $3.30 \mathrm{E}+01$ & 5.21 & $n / a$ & $\mathbf{n} / \mathbf{2}$ & $\mathbf{n} / \mathbf{a}$ \\
\hline \$94T000275 & & & pH on SST Samples & $\mathrm{pH}$ & 100.2 & $n / a$ & 13.08 & 13.05 & $1.31 \mathrm{E}+01$ & 0.23 & $\mathbf{n} / \mathbf{a}$ & $1.00 \mathrm{E}-02$ & $\mathbf{n} / \mathbf{a}$ \\
\hline \$94T000275 & & & DSC Exothern using Mettler & Jouks/g & 100.2 & $n / \mathbf{a}$ & $1.56 \mathrm{E}+02$ & 160.7 & $1.59 \mathrm{E}+02$ & 2.78 & $n / a$ & $\mathbf{n} / \mathbf{a}$ & $\mathrm{n} / \mathbf{a}$ \\
\hline S94T000275 & & & TOC by Persulfate/Coulometry & ug/g & 89.33 & 33.8 & $1.03 \mathrm{E}+04$ & 10800 & $1.06 \mathrm{E}+04$ & 4.74 & $n / a$ & 80 & $n / a$ \\
\hline \$94T000275 & & & TIC by Acid/Coulometry & ug/g & 97.00 & 4.500 & $8.66 x+03$ & $8.95 c+03$ & $8.80 c+03$ & 3.29 & $\mathbf{n} / \mathbf{a}$ & 5.000 & $\mathrm{n} / \mathrm{a}$ \\
\hline S94TOCO278 & & A & Aluminium -ICP-Acid Digest & ug $/ \mathrm{g}$ & 97.6 & $2.60 \mathrm{E}-02$ & $3.48 \mathrm{E}+04$ & 35200 & $3.50 \mathrm{E}+04$ & 1.14 & $n / a$ & 43 & $\mathbf{n} / \mathbf{m}$ \\
\hline $594 \mathrm{~T} 000278$ & & A & Calcium -1CP-Acid Digest & ug/g & 101.2 & $2.10 \mathrm{E}-02$ & $3.55 \mathrm{E}+02$ & 346 & $3.51 \mathrm{E}+02$ & 2.57 & D/a & 85.9 & $\mathrm{n} / \mathbf{a}$ \\
\hline S94 T000278 & & A & Chromium -ICP-Acid Digest & $u g / \mathfrak{g}$ & 95.8 & $1.10 \mathrm{E}-02$ & $6.50 \mathrm{E}+03$ & 6600 & $6.55 \mathrm{E}+03$ & 1.53 & $n / 4$ & 8.59 & $\mathbf{n} / \mathbf{a}$ \\
\hline S94T000278 & & A & Iron -ICP-Acid Digest & ug/k & 96.6 & $4.40 \mathrm{E}-02$ & $2.11 \mathrm{E}+03$ & 2120 & $2.12 \mathrm{E}+03$ & 0.47 & $n / a$ & 43 & n/a \\
\hline $894 \mathrm{~T} 000278$ & b & A & Potassium -ICP-Acid Diseat & นg/s & 121 & 2.15 & $3.31 \mathrm{E}+03$ & 3380 & $3.34 \mathrm{E}+03$ & 2.09 & $\mathbf{n} / \mathbf{a}$ & 258 & $n / a$ \\
\hline$\$ 94 \mathrm{~T} 000278$ & & A & Sodium -ICP-Acid Digest & $u g / \mathbf{g}$ & 99.2 & $1.14 \mathrm{E}-01$ & $1.88 \mathrm{E}+05$ & 186000 & $1.87 \mathrm{E}+05$ & 1.07 & $n / a$ & 172 & $n / \mathbf{a}$ \\
\hline S94T000278 & & A & Nickel -ICP-Acid Digest & ug/g & 94.6 & $7.00 \mathrm{E}-03$ & $1.02 \mathrm{E}+02$ & 101 & $1.02 \mathrm{E}+02$ & 0.99 & $n / \mathbf{n}$ & 17.2 & $n / \mathbf{a}$ \\
\hline S94T000278 & & A & Zinc -ICP-Acid Digest & ug/g & 91.2 & $6.00 \mathrm{E}-03$ & 23.7 & 23.2 & $2.35 \mathrm{E}+01$ & 2.13 & $\mathbf{n} / \mathbf{a}$ & 8.59 & $n / 2$ \\
\hline $594 \mathrm{~T} 000278$ & & A & Zirconium -ICP-Acid Digest & $\omega \mathrm{m} / \mathrm{g}$ & 96.4 & $7.00 \mathrm{E}-03$ & 58.2 & 55 & $5.66 \mathrm{E}+01$ & 5.65 & $\mathrm{n} / \mathbf{a}$ & 8.59 & $\mathrm{n} / \mathrm{a}$ \\
\hline S94T000281 & & w & OH- by Pot. Titration & ug/g & 99.36 & $<60300.0$ & $1.81 E+04$ & 18800 & $1.84 \mathrm{E}+04$ & 3.79 & $\mathbf{n} / \mathbf{a}$ & $5.94 \mathrm{E}+03$ & $n / 4$ \\
\hline s94T000281 & & w & Chromium (VI) by Spec. & $\mathbf{u g} / \mathbf{s}$ & 101.9 & $<2.290 \mathrm{k}-1$ & $1.54 \mathrm{E}+02$ & 148 & $1.51 \mathrm{E}+02$ & 3.97 & 100.6 & 21.75 & $\mathrm{n} / \mathrm{a}$ \\
\hline \$94T000281 & & w & Tritium By Lachat & $\mathrm{uCi} / g$ & 93.8 & $<4.660 \mathrm{k}-4$ & Aapin & aAdis: & $\mathrm{a} / \mathrm{a}$ & $n / a$ & w/a & $1.00 \mathrm{E}-04$ & NAfly \\
\hline
\end{tabular}


Table A-1. Laboratory Data Results for Tank 241-SY-103, Core $62^{1}$.

\begin{tabular}{|c|c|c|c|c|c|c|c|c|c|c|c|c|c|}
\hline stmplo & 6 & $x$ & 1110 & W & $3+19 \%$ & The & Ka. & Whing & (3) & $30 \%$ & $\mathrm{x} x \times \mathrm{x}$ & Dow & 60,45 \\
\hline S94T000281 & & w & Bromide by Ion Chromatograph & $\operatorname{ug} / g$ & 97.9 & $<1.000$ & $<95.10$ & $<96.1$ & $a / a$ & a/a & 88.8 & 95.1 & $n / a$ \\
\hline S\$4T00028! & & w & Chiloride-IC-Dionex $4000 \mathrm{i} / 4500$ & ug/g & 96.4 & $<2.000 k-1$ & $7.08 \mathrm{E}+03$ & 6980 & $7.03 E+03$ & 1.42 & 93.5 & 19 & $n / \mathbf{a}$ \\
\hline S94T00028! & & w & Fluoride-IC-Dionex $4000 \mathrm{i} / 4500$ & ug/g & 94.64 & $<1.000 \mathrm{e}-1$ & $1.55 E+03$ & 1570 & $1.56 \mathrm{E}+03$ & 1.28 & 84.3 & 9.51 & $\mathbf{n} / \mathbf{a}$ \\
\hline S94T000281 & & w & Nitrite-IC - Dionex 4000i/4500 & ug/g & 96.4 & $<1.000$ & $8.06 \mathrm{E}+04$ & 83200 & $8.19 \mathrm{E}+04$ & 3.17 & 102.1 & 95.1 & $\mathrm{n} / \mathrm{a}$ \\
\hline s94T000281 & & w & Nitrate by IC-Dionex $4000 \mathrm{i} / 4500$ & ug/g & 97.23 & $<1.000$ & $9.72 \mathrm{E}+04$ & 99000 & $9.81 E+04$ & 1.83 & 97.6 & 95.1 & $n / a$ \\
\hline S94T000281 & & w & Oxalate by IC - Dionex 4000 i & $\log / g$ & 95.43 & $<1.000$ & $2.07 \mathrm{E}+04$ & 200800 & $2.08 \mathrm{E}+04$ & 0.48 & 90.7 & 95.1 & $n / \mathbf{a}$ \\
\hline S\$4T000281 & & w & Phosphate-IC-Dionex $4000: / 4500$ & ugg/g & 96.7 & $<1.000$ & $1.55 \mathrm{E}+04$ & 15800 & $1.56 \mathrm{E}+04$ & 1.92 & 88.4 & 95.1 & $w / n$ \\
\hline S94T000281 & & $w$ & Sulfate by IC-Dionex $4000 \mathrm{i} / 4500$ & $\mathrm{ug} / \mathrm{g}$ & 95.99 & $<1.000$ & $7,77 \mathrm{E}+03$ & 7880 & $7.82 \mathrm{E}+03$ & 1.41 & 88 & 95.1 & $n / 2$ \\
\hline S94T000281 & & w & Acetate by IC - Dionex $4000 \mathrm{i}$ & ug/g & $n / \Perp$ & $<1.000$ & $3.168+03$ & 3100 & $3.13 \mathrm{E}+03$ & 1.92 & 100.6 & 95 & $n / 2$ \\
\hline S94T000281 & & $w$ & Formate by IC - Dionex $4000 \mathrm{i}$ & ug $/ g$ & $\mathbf{a} / \mathrm{a}$ & $<1.000$ & $4.83 \mathrm{E}+03$ & 5090 & $4.96 \mathrm{E}+03$ & 5.24 & 90.1 & 95 & $n / \mathbf{a}$ \\
\hline S94T000284 & & $R$ & Am-241 by Extraction & $\mathrm{uCi} / \mathrm{g}$ & 87.55 & $<2.500 \mathrm{k}-3$ & $7.87 \mathrm{E}-03$ & $<2.37<-3$ & $n / n$ & n/a & $n / 2$ & $3.00 \mathrm{E}-03$ & 6.6 \\
\hline \$94T000284 & & $R$ & Crm-243/244 by Extraction & $\omega \mathrm{Ci} / \mathrm{g}$ & $\mathrm{a} / \mathrm{a}$ & $<2.500-3$ & $<2.51 \mathrm{e}-03$ & $<2.37 e-3$ & $n / \mathbf{a}$ & n/a & $n / 2$ & $3.00 \mathrm{E}-03$ & 24.6 \\
\hline S94T000284 & & $\mathbf{R}$ & Cobalt- 60 by GEA & $\mathrm{uCi} / \mathrm{g}$ & 97.06 & $<2.990 \mathrm{e}-3$ & $<1.14 \mathrm{e}-02$ & 0.0228 & $n / \mathbf{a}$ & n/s & $n / a$ & 3.00E-03 & $n \underline{a}$ \\
\hline $594 T 000284$ & & $\mathbf{R}$ & Cesium-137 by GEA & $\mathrm{uCi} / \mathrm{g}$ & 94.64 & $<6.900 \mathrm{e}-3$ & $2.50 \mathrm{E}+02$ & 251 & $2.51 \mathrm{E}+02$ & 0.4 & $n / n$ & $7.00 \mathrm{E}-03$ & 0.15 \\
\hline $594 T 000284$ & & $\mathbf{R}$ & Europium-154 by GEA & $\mathrm{uCi}_{\mathrm{g}}$ & $n / a$ & $<6.390 \mathrm{e}-3$ & $<5.47 \mathrm{e}-102$ & $<5.37 e-2$ & $n / \mathbf{a}$ & $n / 4$ & n/a & $6.00 \mathrm{E}-03$ & na \\
\hline S94T000284 & & $\mathbf{R}$ & Europium-155 by GEA & $\mathrm{uC} j / \mathrm{g}$ & D/a & $<7.000 \mathrm{c}-3$ & $<1.81 \mathrm{e}-01$ & $<1.83 \mathrm{e}-1$ & $n / 2$ & $n / a$ & $n / a$ & $7.00 \mathrm{E}-03$ & nia \\
\hline s94T000284 & & $R$ & Np237 by TTA Extraction & $\mathrm{uCi} / \mathrm{g}$ & 80.17 & $<2.420<-3$ & $<2.60 \mathrm{k}-03$ & $<3.590-3$ & $n / n$ & $\mathbf{n} / \mathbf{a}$ & 80.4 & $5.00 \mathrm{E}-103$ & 500 \\
\hline S94T000284 & & $\mathbf{R}$ & Pu-238 by lon Exchange & uCi/g & $a / 2$ & $<7.940 e-4$ & $5.07 \mathrm{E}-04$ & $<3.95 \mathrm{e}-4$ & $\mathbf{a} / \mathbf{a}$ & $0 / a$ & $n / a$ & 3.72E-04 & 7.1 \\
\hline
\end{tabular}


Table A-1. Laboratory Data Results for Tank 241-SY-103, Core $62^{1}$.

\begin{tabular}{|c|c|c|c|c|c|c|c|c|c|c|c|c|c|}
\hline somple & 0 & 1 & way & 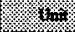 & xy, & 1) & $\mathrm{x}^{-4}$ & on & 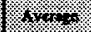 & ats & 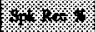 & 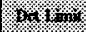 & 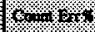 \\
\hline$\$ 94 \mathrm{~T} 000284$ & & $\mathbf{R}$ & Pu-239/240 by TRU-SPEC Resin & $u C i / g$ & 113.4 & $<7.940 e-4$ & 9.41E-04 & $<3.95=-4$ & $\mathbf{n} / \mathbf{n}$ & $\mathrm{n} / \mathbf{a}$ & a/a & $3.72 \mathrm{E}-04$ & 100 \\
\hline$\$ 94 T 000284$ & & $\mathbf{R}$ & Stroatium-89/90 Kigh Level & $\sim \mathrm{Ci} / \mathrm{g}$ & 91.89 & $2.10 \mathrm{E}-02$ & 2.21 & 2.1 & $2.16 \mathrm{E}+\infty 0$ & 5.1 & $n / a$ & $2.10 \mathrm{E}-02$ & 4.3 \\
\hline $594 \mathrm{~T} 000300$ & & $\mathbf{F}$ & Uranium by Phosphorescence & Lg/g $/ g$ & 108.5 & $<2.120 \mathrm{e}-2$ & $8.18 \mathrm{E}+02$ & 735 & $7.77 \mathrm{E}+02$ & 10.7 & 113.1 & $2.10 \mathrm{E}-02$ & $n / \mathbf{n}$ \\
\hline S94T000300 & & $\mathbf{F}$ & Alpha of Digested Solid & $\mathrm{uCi} / \mathrm{g}$ & 97.6 & $<3.270 \mathrm{e}-3$ & $6.01 \mathrm{E}-01$ & 0.535 & $5.68 \mathrm{E}-01$ & 11.6 & 82.6 & $5.00 \mathrm{E}-03$ & 4.1 \\
\hline $594 \mathrm{~T} 000300$ & & $\mathbf{F}$ & Am-24I by Exaraction & $\omega \mathrm{Ci} / \mathrm{g}$ & 102.5 & $<5.790 \mathrm{e}-2$ & $7.11 \mathrm{E}-01$ & 0.625 & $6.68 \mathrm{E}-01$ & 12.9 & $\mathbf{n} / \mathbf{a}$ & $1.02 \mathrm{E}-01$ & 6.9 \\
\hline $594 \mathrm{~T} 000300$ & & $F$ & $\mathrm{Cm}-243 / 244$ by Extraction & $u C i / g$ & $n / \mathbf{a}$ & $<5.790 \mathrm{k}-2$ & $<1.02 e-01$ & $<1.13 e-1$ & $n / a$ & $\mathbf{n} / \mathbf{a}$ & $n / 2$ & $1.02 \mathrm{E}-01$ & 22.5 \\
\hline $594 \mathrm{~T} 000300$ & e & $F$ & Beta of Solid Sample & uCi/g & 108.2 & $9.80 \mathrm{E}-02$ & $4.96 \mathrm{E}+02$ & 368 & $4.32 \mathrm{E}+\infty 2$ & 29.6 & 98.2 & $1.62 \mathrm{E}-01$ & 0.4 \\
\hline $594 \mathrm{~T} 000300$ & & $\mathbf{F}$ & Cobalt- 60 by GEA & uCi/g & 105.4 & $<2.090 \mathrm{e}-2$ & $5.21 \mathrm{E}-02$ & 0.0458 & $4.90 \mathrm{E}-02$ & 12.9 & $\mathbf{n} / \mathbf{a}$ & $2.10 \mathrm{E}-02$ & 23.21 \\
\hline s94T000300 & e & F & Cesium-137 by GEA & $u C i^{\prime} / g$ & 96.94 & $<3.970 \mathrm{k}-2$ & $2.68 \mathrm{E}+02$ & 196 & $2.32 \mathrm{E}+02$ & 31 & $\mathbf{n} / \mathbf{a}$ & $4.00 \mathrm{E}-02$ & 0.29 \\
\hline S94T000300 & & $\mathbf{F}$ & Europium-154 by GEA & $u C i / g$ & $n / a$ & $<3.630 \mathrm{e}-2$ & $7.97 \mathrm{E}-01$ & 0.712 & 7.54E-01 & 11.3 & $\mathbf{n} / \mathbf{a}$ & $3.60 \mathrm{E}-02$ & 15.8 \\
\hline$\$ 94 T 000300$ & & $\mathbf{F}$ & Europium-155 by GEA & uCi/g & $n / 2$ & $<4.580<.2$ & $<7.21 \mathrm{e}-01$ & 0.655 & $n / n$ & $\mathbf{n} / \mathbf{k}$ & $\mathbf{n} / \mathbf{a}$ & $4.60 \mathrm{E}-02$ & nis \\
\hline S94T000300 & & $\mathbf{F}$ & lodine-129 Waste Tank Samples & $\mathrm{uCi} / \mathrm{g}$ & 107.9 & $<1.040 \mathrm{e}-1$ & $<1.46 \mathrm{e}-0 \mathrm{l}$ & $<5.25 \mathrm{e}-2$ & $n / n$ & $\mathbf{n} / \mathbf{a}$ & $\mathbf{n} / \mathbf{a}$ & $1.46 \mathrm{E}-01$ & nin \\
\hline $594 \mathrm{~T} 000300$ & & $\mathbf{F}$ & Calciurn-ICP-Fusion & ug/g & 102 & $4.58 \mathrm{E}-01$ & $<3.95 x+02$ & LDL & $n / a$ & $\mathbf{n} / \mathbf{a}$ & $\mathbf{n} / \mathbf{a}$ & 395 & $n / 2$ \\
\hline $594 \mathrm{~T} 000300$ & & $\mathbf{F}$ & Potassium -ICP-Fusion (2) & ug/g & 100 & $6.10 \mathrm{E}-02$ & Anif: & $n / a$ & $n / a$ & $n / a$ & $n / a$ & $1.18 \mathrm{E}+03$ & $n / 2$ \\
\hline s94T000300 & e & F & Sodium -ICP-Fusion & ug/g & 98 & 3.87 & $1.61 \mathrm{E}+05$ & 120000 & $1.40 \mathrm{E}+05$ & 29.2 & $\mathbf{n} / \mathbf{a}$ & 395 & $n / a$ \\
\hline $594 T 000300$ & & $\mathbf{F}$ & Nicket -ICP-Fusion (2) & ug/g & 100.8 & 2.09 & $\mathrm{n} / \mathbf{a}$ & $n / a$ & $\mathrm{D} / \mathrm{a}$ & n/s & n/a & 79 & $n / a$ \\
\hline$\$ 94 T 000300$ & & $\mathbf{F}$ & Zinc -ICP-Fusion & $\mathrm{ug} / \mathrm{g}$ & 102.8 & $-2.20 \mathrm{E}-02$ & $<39.50$ & LDL & a/a & $\mathrm{n} / \mathbf{n}$ & $\mathrm{p} / \mathrm{a}$ & 39.5 & $\mathbf{n} / \mathbf{a}$ \\
\hline $894 \mathrm{~T} 000300$ & & $\mathbf{F}$ & Zirconium -ICP-Fustion & $\log / 8$ & 99.6 & $6.70 \mathrm{E}-02$ & $<39.50$ & LDL & a/a & n/a & $\mathbf{n} / \mathbf{a}$ & 39.5 & $n / n$ \\
\hline S94T000300 & a & $\mathbf{F}$ & Np237 by TTA Extraction & uCi/g & 71.07 & $9.00 \mathrm{E}-03$ & $<1.49-02$ & $<1.20 \mathrm{k}-2$ & $n / 2$ & $\mathrm{n} / \mathbf{a}$ & 82 & $1.50 \mathrm{E}-02$ & 129 \\
\hline
\end{tabular}


Table A-1. Laboratory Data Results for Tank 241-SY-103, Core $62^{1}$.

\begin{tabular}{|c|c|c|c|c|c|c|c|c|c|c|c|c|c|}
\hline Sumplot & 0 & 10 & (2) & $1 \%$ & 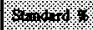 & 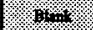 & ew & inptis $=0$ & $x \times$ & 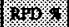 & 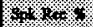 & 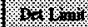 & $\%=x$ \\
\hline S94T000300 & & $\mathbf{F}$ & Pu-238 by Ion Exchange & |uCig & $n / a$ & $<2.900 \mathrm{c}-3$ & $1.55 \mathrm{E}-02$ & 0.0169 & $1.62 \mathrm{E}-02$ & 8.64 & $\mathbf{p} / \mathbf{a}$ & $8.00 \mathrm{E}-03$ & 4.5 \\
\hline$\$ 94 \mathrm{~T} 000300$ & & F & Pu-239/240 by TRU-SPEC Resin & uCij/g & 112.7 & $<2.900 \mathrm{e}-3$ & $6.67 \mathrm{E}-02$ & 0.0579 & $6.23 \mathrm{E}-02$ & 14.1 & $n / a$ & $8.00 \mathrm{E}-03$ & 2.6 \\
\hline S9ST00029t & & w & Iodine-129 Waste Tank Srmpies & $\mathrm{uCi} / \mathrm{g}$ & 114.8 & $<2.2990-2$ & $<2.346-02$ & $<2.23 e-2$ & $n / \mathbf{a}$ & $n / 2$ & $n / a$ & $2.30 \mathrm{E}-02$ & $\alpha / a$ \\
\hline S95T000296 & & $\mathbf{R}$ & Technetium-99 Liq. Scint. & |uCi/g & 101.2 & $<1.7500-3$ & $1.42 \mathrm{E}-01$ & 0.127 & $1.35 \mathrm{E}-01$ & 11.2 & $\mathbf{n} / \mathbf{2}$ & $2.00 \mathrm{E}-03$ & 1.79 \\
\hline S95T001395 & & F & Chromium -ICP-Fusion & $\mathrm{ug} / \mathrm{g}$ & 101.3 & $8.90 \mathrm{E}-12$ & $1.07 E+04$ & 9700 & $1.02 \mathrm{E}+04$ & 10.2 & $\mathbf{n} / \mathbf{a}$ & 48.4 & $n / \mathbf{a}$ \\
\hline S95T001395 & & F & Iroa -ICP-Fusion & ug $/ g$ & 100 & 4.319 & $2.86 \mathrm{E}+03$ & 2550 & $2.70 \mathrm{E}+03$ & 11.3 & $\mathrm{n} / \mathrm{a}$ & 242 & $n / \mathbf{n}$ \\
\hline
\end{tabular}


Table A-1. Laboratory Data Results for Tank 241-SY-103, Core $62^{1}$.

\begin{tabular}{|c|c|c|c|c|c|c|c|c|c|c|c|c|c|}
\hline sumplot & 0 & wi & 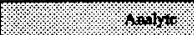 & lutive & 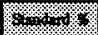 & $18+1$ & 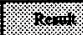 & Diphoris & Now:t: & (ntw & $3 \times 1040$ & 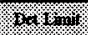 & 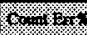 \\
\hline S95T001395 & ff & F & Technetium-99 Liq. Scint. & uCi/g & 104.1 & $3.60 \mathrm{E}-122$ & 2.42E- -1 & 0.246 & $2.44 \mathrm{E}-01$ & 1.64 & $n / \mathbf{a}$ & $1.50 \mathrm{E}-02$ & 3.6 \\
\hline
\end{tabular}

Notes:

LDL $=$ less than detect in limit

$\mathrm{R} \quad=$ replicate analysis

AH = aliquot class

$\mathrm{A}=$ acid-digest

B $=$ scid digestion of a liquid

D $=$ acid dilution

$F=$ fusion digested sample

$\mathrm{n} / \mathbf{a}=\mathbf{n o t}$ appliceble

$\begin{array}{ll}\mathrm{n} / \mathrm{a} & =\text { not applicable } \\ \mathrm{I} & =\text { water digested - acid added to sample for ICP }\end{array}$

$\mathrm{R}=$ water digest-acid added sample for radiochemistry

$\mathrm{V}=$ water dilution

$\mathrm{W}=$ water digest-no acid

(2) = Ni crucible and $\mathrm{KOH}$ are used in fusion

(3) \# Result is a rerun analysis

(4) = Amalyses were run on centrifuged solids. Other strata B analyses performer on slurry of solids/liquid.

Perkin Emer is a trademark of Pertin-Elmer Corporation, Norwalk, Connecticut Mettler is a trademant of Metller Instrument Corporation, Highstown, New Jersey

Dionex is a trademark of Dionex Corporation, Sunnyvale, Californin.

Lachat is a trademart of Lachat, Inc., Milwaukee, Wisconsin

TRU-SPEC Resins is a trademark of Eichrom Industries, Darien, Illinois,

'Rice (1995) 
WHC-SD-WM-ER-471 Rev. 1

This page intentionally left blank. 
WHC-SD-WM-ER-471 Rev. 1

APPENDIX B

\section{AUGER SAMPLING DATA}

B-1 
WHC-SD-WM-ER-471 Rev. 1

This page intentionally left blank. 
Table B-1. 136-Day Deliverable Summary Table for Tank 241-SY-103 Auger Sample - Riser 7B.

Riser 7B, Subsample A: Flutes 1, 2, 3, 4, and 6

\begin{tabular}{|c|c|c|c|c|c|c|c|c|c|c|}
\hline Analysis (units) & Lab ID \# & $\begin{array}{l}\text { Notification } \\
\text { Limits }\end{array}$ & $\begin{array}{c}\text { Std Recovery } \\
(\mathscr{(})\end{array}$ & Prep Blank & Sample & Duplicate & Mean & $\begin{array}{l}\text { RPD } \\
(\%)\end{array}$ & $\begin{array}{c}\text { Spike Rec. } \\
\text { (\%) }\end{array}$ & Det. Limit \\
\hline $\mathrm{DSC}(\mathrm{cal} / \mathrm{g})$ & R5398 & $\begin{array}{c}>586 \mathrm{~J} / \mathrm{g} \\
\text { (dry) }\end{array}$ & 103.0 & NA & NO EXO & NO EXO & NA & NA & NA & NA \\
\hline TGA ( $\%$ water) & R5398 & NA & 95.9 & NA & 8.02 & 8.56 & 8.29 & 6.51 & NA & NA \\
\hline
\end{tabular}

Riser 7B, Subsample B: Flutes 1, 2, 3, 4, and 6

\begin{tabular}{|c|c|c|c|c|c|c|c|c|c|c|}
\hline Analysis (units) & Lab ID \# & $\begin{array}{c}\text { Notification } \\
\text { Limits }\end{array}$ & $\begin{array}{c}\text { Std Recovery } \\
(\%)\end{array}$ & Prep Blank & Sample & Duplicate & Mean & $\begin{array}{c}\text { RPD } \\
(\%)\end{array}$ & $\begin{array}{c}\text { Spike Rec. } \\
(\%)\end{array}$ & \begin{tabular}{c} 
Det. Limit \\
\hline DSC (cal/g)
\end{tabular} \\
R5399 & $\begin{array}{c}>586 \mathrm{~J} / \mathrm{g} \\
\text { (dry) }\end{array}$ & 102.3 & NA & NO EXO & NO EXO & NA & NA & NA & NA \\
\hline & & & & & & & & & & \\
\hline TGA (\% water) & R5399 & NA & 98.5 & NA & 11.96 & 17.82 & 14.89 & 39.3 & NA & NA \\
\hline
\end{tabular}

Riser 7B, Composite: Flutes 1, 2, 3, 4, and 6

\begin{tabular}{|c|c|c|c|c|c|c|c|c|c|c|}
\hline Analysis (units) & Lab ID \# & $\begin{array}{c}\text { Notification } \\
\text { Limits }\end{array}$ & $\begin{array}{c}\text { Std Recovery } \\
(\%)\end{array}$ & Prep Blank & Sample & Duplicate & Mean & $\begin{array}{c}\text { RPD } \\
(\%)\end{array}$ & $\begin{array}{c}\text { Spike Rec. } \\
(\%)\end{array}$ & $\begin{array}{l}\text { Det. Limit } \\
\text { TIC }(\mu \mathrm{g} / \mathrm{C} / \mathrm{g})\end{array}$ \\
\hline & R5430 & NA & 94.6 & $4.30 \mu \mathrm{g} \mathrm{C}$ & $2.25 \mathrm{E}+04$ & $3.13 \mathrm{E}+04$ & $2.69 \mathrm{E}+04$ & 32.7 & NA & $4.00 \mathrm{E}+02$ \\
\hline & & & & & & & & & \\
\hline TOC $(\mu \mathrm{g} / \mathrm{C} / \mathrm{g})$ & R5430 & $\begin{array}{c}>3.00 \mathrm{E}+04 \\
(\mu \mathrm{gC} / \mathrm{g})\end{array}$ & 90.0 & $17.60 \mu \mathrm{g} \mathrm{C}$ & $1.00 \mathrm{E}+04$ & $7.70 \mathrm{E}+03$ & $8.85 \mathrm{E}+03$ & 26.0 & NA & $4.00 \mathrm{E}+02$ \\
\hline
\end{tabular}


WHC-SD-WM-ER-471 Rev. 1

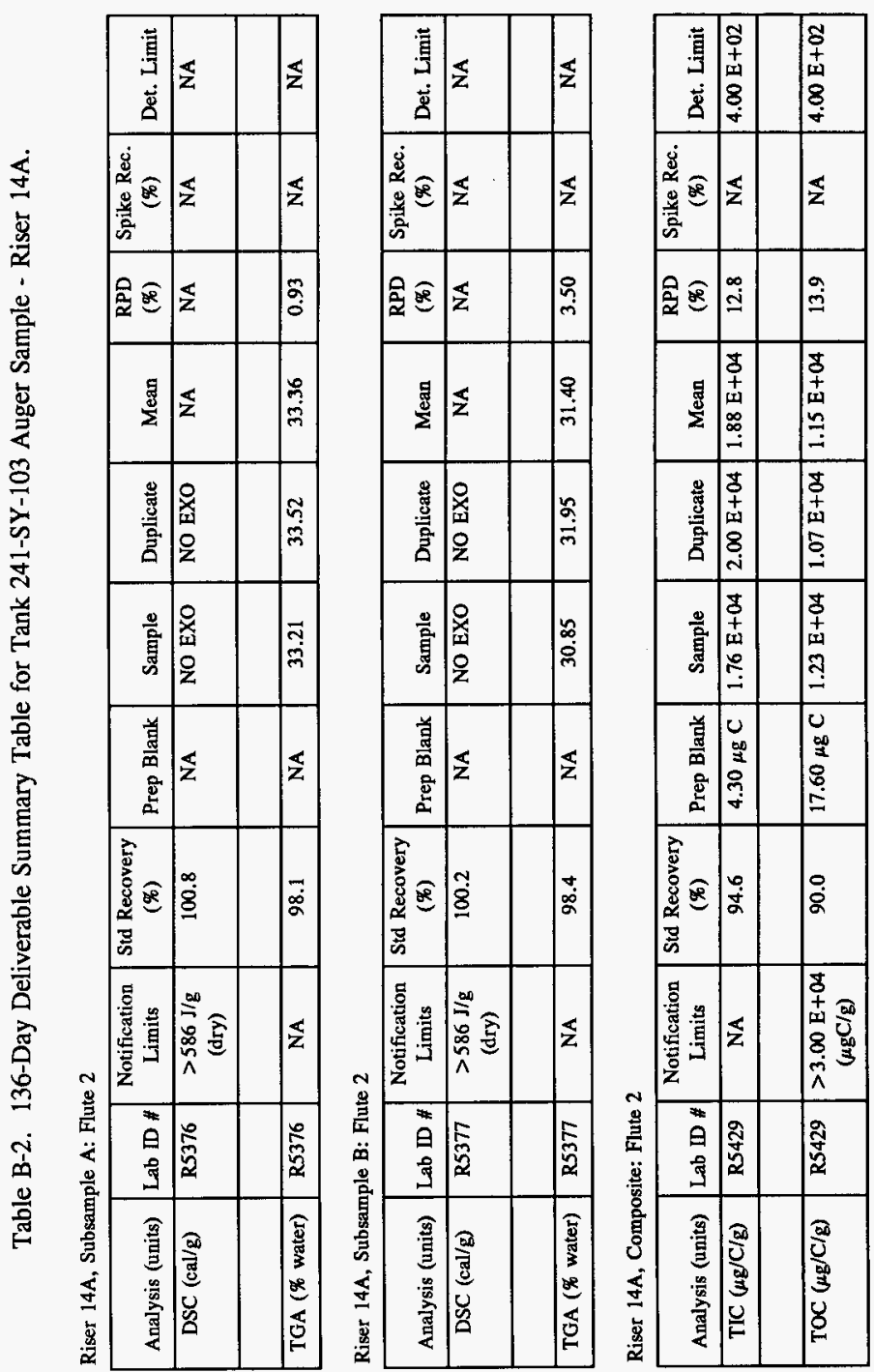


Table B-3. 136-Day Deliverable Summary Table for Tank 241-SY-103 Auger Sample - Riser 22A.

Riser 22A, Subsample A: Flute 2

\begin{tabular}{|c|c|c|c|c|c|c|c|c|c|c|}
\hline Analysis (units) & Lab ID \# & $\begin{array}{c}\text { Notification } \\
\text { Limits }\end{array}$ & $\begin{array}{c}\text { Std Recovery } \\
(\%)\end{array}$ & Prep Blank & Sample & Duplicate & Mean & $\begin{array}{c}\text { RPD } \\
(\%)\end{array}$ & $\begin{array}{c}\text { Spike Rec. } \\
(\%)\end{array}$ & Det. Limit \\
\hline DSC (cal/g) & R5372 & $\begin{array}{c}>586 \mathrm{~J} / \mathrm{g} \\
\text { (dry) }\end{array}$ & 105.1 & NA & NO EXO & NO EXO & NA & NA & NA & NA \\
\hline & & & & & & & & & & \\
\hline TGA (\% water) & R5372 & NA & 102.2 & NA & 11.37 & 11.98 & 11.67 & 5.23 & NA & NA \\
\hline
\end{tabular}

Riser 22A, Subsample B: Flute 3

\begin{tabular}{|c|c|c|c|c|c|c|c|c|c|c|}
\hline Analysis (units) & Lab ID \# & $\begin{array}{l}\text { Notification } \\
\text { Limits }\end{array}$ & $\begin{array}{c}\text { Std Recovery } \\
(\%)\end{array}$ & Prep Blank & Sample & Duplicate & Mean & $\begin{array}{c}\text { RPD } \\
(\%)\end{array}$ & $\begin{array}{l}\text { Spike Rec. } \\
\text { (\%) }\end{array}$ & Det. Limit \\
\hline $\mathrm{DSC}(\mathrm{cal} / \mathrm{g})$ & $\mathbf{R 5 3 7 3}$ & $\begin{array}{c}>586 \mathrm{~J} / g \\
\text { (dry) }\end{array}$ & 105.1 & NA & NO EXO & NA & NA & NA & NA & NA \\
\hline DSC (cal/g) & R5373 & $\begin{array}{c}>586 \mathrm{~J} / \mathrm{g} \\
(\mathrm{dry})\end{array}$ & 105.1 & NA & NA & NO EXO & NA & NA & NA & NA \\
\hline TGA ( $\%$ water) & $\mathbf{R 5 3 7 3}$ & $\overline{\mathrm{NA}}$ & 98.1 & NA & 24.04 & 23.61 & 23.82 & 1.80 & NA & NA \\
\hline
\end{tabular}

Riser 22A, Subsample C: Flute 6

\begin{tabular}{|c|c|c|c|c|c|c|c|c|c|c|}
\hline Analysis (units) & Lab ID \# & $\begin{array}{l}\text { Notification } \\
\text { Limits }\end{array}$ & $\begin{array}{c}\text { Std Recovery } \\
\text { (\%) }\end{array}$ & Prep Blank & Sample & Duplicate & Mean & $\begin{array}{c}\text { RPD } \\
\left(\psi_{0}\right)\end{array}$ & $\begin{array}{l}\text { Spike Rec. } \\
\text { (\%) }\end{array}$ & Det. Limit \\
\hline DSC (cal/g) & R5374 & $\begin{array}{c}>586 \mathrm{~J} / \mathrm{g} \\
\text { (dry) }\end{array}$ & 105.1 & NA & NO EXO & NO EXO & $\overline{\mathbf{N A}}$ & $\overline{\text { NA }}$ & $\overline{\mathbf{N A}}$ & NA \\
\hline TGA ( $\%$ water) & R5374 & NA & 98.1 & NA & 26.84 & 23.93 & 25.38 & 1.80 & NA & $\overline{\mathrm{NA}}$ \\
\hline
\end{tabular}


Table B-3. 136-Day Deliverable Summary Table for Tank 241-SY-103 Auger Sample - Riser 22A.

Riser 22A, Subsample D: Flute 7

\begin{tabular}{|c|c|c|c|c|c|c|c|c|c|c|}
\hline Analysis (units) & Lab ID \# & $\begin{array}{l}\text { Notification } \\
\text { Limits }\end{array}$ & $\begin{array}{c}\text { Std Recovery } \\
\text { (\%) }\end{array}$ & Prep Blank & Sample & Duplicate & Mean & $\begin{array}{l}\text { RPD } \\
(\%)\end{array}$ & $\begin{array}{c}\text { Spike Rec. } \\
\text { (\%) }\end{array}$ & Det. Limit \\
\hline DSC $(\mathrm{cal} / \mathrm{g})$ & R5375 & $\begin{array}{c}>586 \mathrm{~J} / \mathrm{g} \\
\text { (dry) }\end{array}$ & 100.8 & $\overline{\mathrm{NA}}$ & NO EXO & NO EXO & NA & NA & NA & NA \\
\hline TGA (\% water) & R5375 & $\overline{\mathrm{NA}}$ & 98.1 & NA & 26.29 & 24.77 & 25.53 & 5.95 & NA & NA \\
\hline
\end{tabular}

Riser 22A, Composite 1: Flute 1-3

\begin{tabular}{|c|c|c|c|c|c|c|c|c|c|c|}
\hline Analysis (units) & Lab ID \# & $\begin{array}{c}\text { Notification } \\
\text { Limits }\end{array}$ & $\begin{array}{c}\text { Std Recovery } \\
(\%)\end{array}$ & Prep Blank & Sample & Duplicate & Mean & $\begin{array}{l}\text { RPD } \\
(\%)\end{array}$ & $\begin{array}{c}\text { Spike Rec. } \\
\text { (\%) }\end{array}$ & Det. Limit \\
\hline TIC $(\mu \mathrm{g} / \mathrm{C} / \mathrm{g})$ & R5425 & NA & 100.0 & $3.40 \mu \mathrm{g} \mathrm{C}$ & $8.19 \mathrm{E}+03$ & $7.00 \mathrm{E}+03$ & $7.60 \mathrm{E}+03$ & 15.7 & $\sim 183.0$ & $4.00 \mathrm{E}+02$ \\
\hline TOC $(\mu \mathrm{g} / \mathrm{C} / \mathrm{g})$ & R5425 & $\begin{array}{c}>3.00 \mathrm{E}+04 \\
(\mu \mathrm{gC} / \mathrm{g})\end{array}$ & 95.0 & $27.1 \mu \mathrm{g} \mathrm{C}$ & $1.03 \mathrm{E}+04$ & $6.39 \mathrm{E}+03$ & $8.34 \mathrm{E}+03$ & -46.9 & 91.0 & $4.00 \mathrm{E}+02$ \\
\hline
\end{tabular}

Riser 22A, Composite 2: Flute 4-8

\begin{tabular}{|c|c|c|c|c|c|c|c|c|c|c|}
\hline Analysis (units) & Lab ID \# & $\begin{array}{c}\text { Notification } \\
\text { Limits }\end{array}$ & $\begin{array}{c}\text { Std Recovery } \\
\text { (\%) }\end{array}$ & Prep Blank & Sample & Duplicate & Mean & $\begin{array}{l}\text { RPD } \\
(\%)\end{array}$ & $\begin{array}{l}\text { Spike Rec. } \\
\text { (\%) }\end{array}$ & Det. Limit \\
\hline $\mathrm{TIC}(\mu \mathrm{g} / \mathrm{C} / \mathrm{g})$ & R5426 & NA & 100.0 & $3.40 \mu \mathrm{g} \mathrm{C}$ & $1.11 \mathrm{E}+04$ & $1.52 \mathrm{E}+04$ & $1.32 \mathrm{E}+04$ & $\sim 31.2$ & $\sim 230.0$ & $4.00 \mathrm{E}+02$ \\
\hline $\mathrm{TOC}(\mu \mathrm{g} / \mathrm{C} / \mathrm{g})$ & R5426 & $\begin{array}{c}>3.00 \mathrm{E}+04 \\
(\mu \mathrm{gC} / \mathrm{g})\end{array}$ & 95.0 & $27.1 \mu \mathrm{g} \mathrm{C}$ & $9.46 \mathrm{E}+03$ & $7.47 \mathrm{E}+03$ & $8.47 \mathrm{E}+03$ & -26.0 & -60.7 & $4.00 \mathrm{E}+02$ \\
\hline
\end{tabular}

Note:

TCP Laboratory Acceptance Criteria Exceeded 
WHC-SD-WM-ER-471 Rev. 1

APPENDIX C

1986 CORE SAMPLING DATA

C-1 
WHC-SD-WM-ER-471 Rev. 1

This page intentionally left blank.

$\mathrm{C}-2$ 
WHC-SD-WM-ER-471 Rev. 1

Table C-1. Elements and Anion Concentrations of Waste from

Double-Shell Tank 241-SY-103.

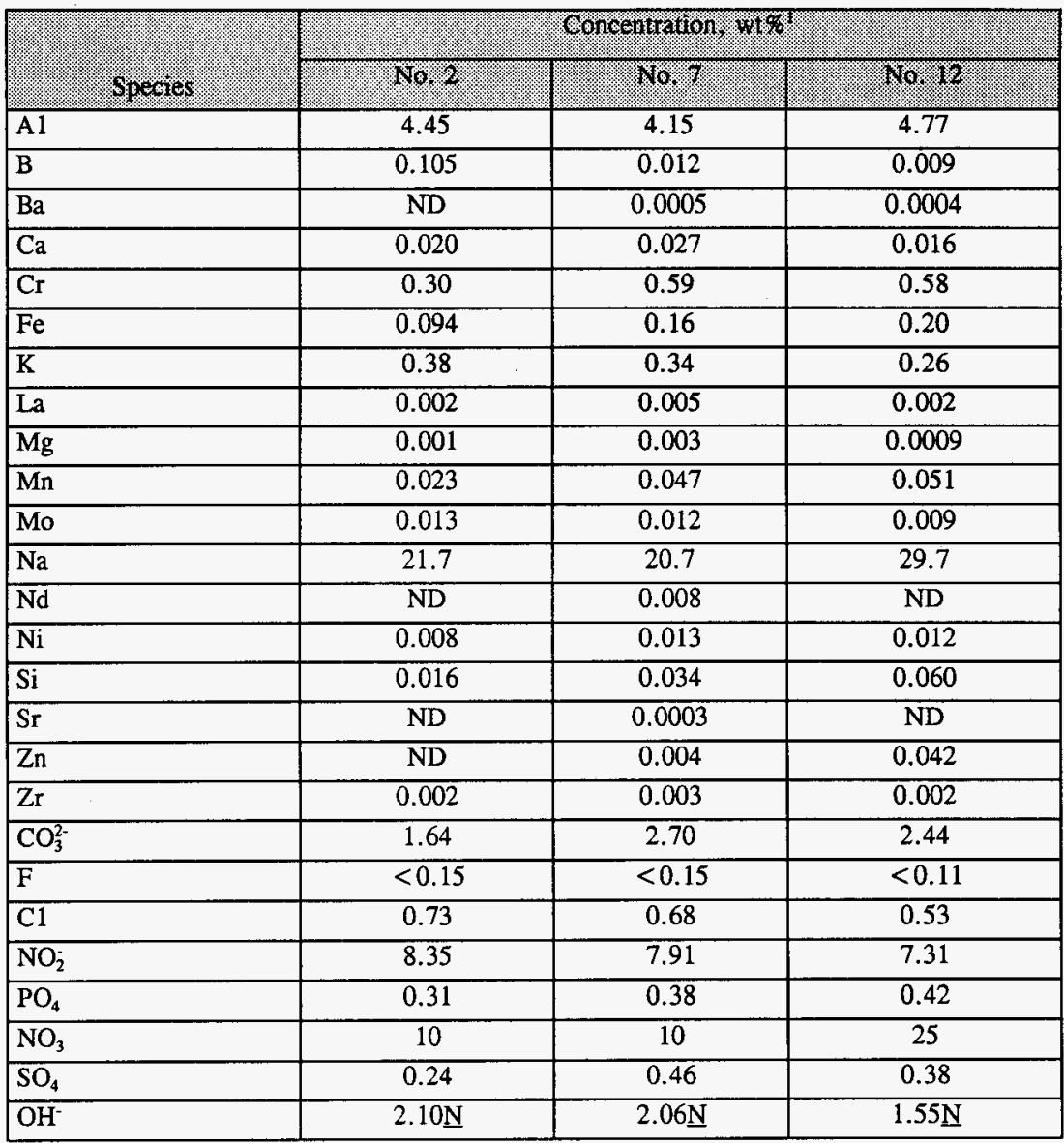

Notes:

$\mathrm{ND}=$ Not detected

'With the exception of HO' 
Table C-2. Radionuclide Concentrations of Waste from Double-Shell Tank 241-SY-103.

\begin{tabular}{|c|c|c|c|}
\hline & \multicolumn{3}{|c|}{ Sample Nimber, ne elo of Sample } \\
\hline Radionindide & No. 2 & No. & No. 12 \\
\hline Total beta & $6.09 \mathrm{E}-1 \pm 1.22 \mathrm{E}-2$ & $6.21 \mathrm{E}-1 \pm 1.38 \mathrm{E}-2$ & $5.09 \mathrm{E}-1 \pm 1.40 \mathrm{E}-2$ \\
\hline${ }^{239-240} \mathrm{Pu}$ & $3.81 \mathrm{E}-5 \pm 1.91 \mathrm{E}-6$ & $7.03 \mathrm{E}-5 \pm 1.84 \mathrm{E}-6$ & $7.38 \mathrm{E}-5 \pm 1.87 \mathrm{E}-6$ \\
\hline${ }^{241} \mathrm{Am}+{ }^{238} \mathrm{Pu}$ & $3.21 \mathrm{E}-4 \pm 21.9 \mathrm{E}-5$ & $5.15 \mathrm{E}-4 \pm 2.30 \mathrm{E}-5$ & $6.35 \mathrm{E}-4 \pm 3.74 \mathrm{E}-5$ \\
\hline${ }^{241} \mathrm{Pu}$ & $4.59 \mathrm{E}-3 \pm 1.87 \mathrm{E}-3$ & $<5.15 \mathrm{E}-3$ & $<5.37 \mathrm{E}-3$ \\
\hline${ }^{60} \mathrm{Co}$ & $8.32 \mathrm{E}-5 \pm 2.60 \mathrm{E}-5$ & $1.47 \mathrm{E}-4 \pm 3.36 \mathrm{E}-5$ & $3.64 \mathrm{E}-4 \pm 2.66 \mathrm{E}-5$ \\
\hline${ }^{137} \mathrm{Cs}$ & $4.95 \mathrm{E}-1 \pm 8.12 \mathrm{E}-3$ & $4,78 \mathrm{E}-1 \pm 1.38 \mathrm{E}-2$ & $3.46 \mathrm{E}-1 \pm 6.07 \mathrm{E}-3$ \\
\hline${ }^{154} \mathrm{Eu}$ & $7.75 \mathrm{E}-4 \pm 9.33 \mathrm{E}-5$ & $1.49 \mathrm{E}-3 \pm 1.56 \mathrm{E}-4$ & $2.12 \mathrm{E}-3 \pm 1.07 \mathrm{E}-3$ \\
\hline${ }^{155} \mathrm{Eu}$ & $6.21 \mathrm{E}-4 \pm 2.23 \mathrm{E}-4$ & $1.84 \mathrm{E}-3 \pm 2.62 \mathrm{E}-4$ & $<1 / 36 \mathrm{E}-3$ \\
\hline
\end{tabular}


Table C-3. Solids Settling Behavior for Sample No. 2.

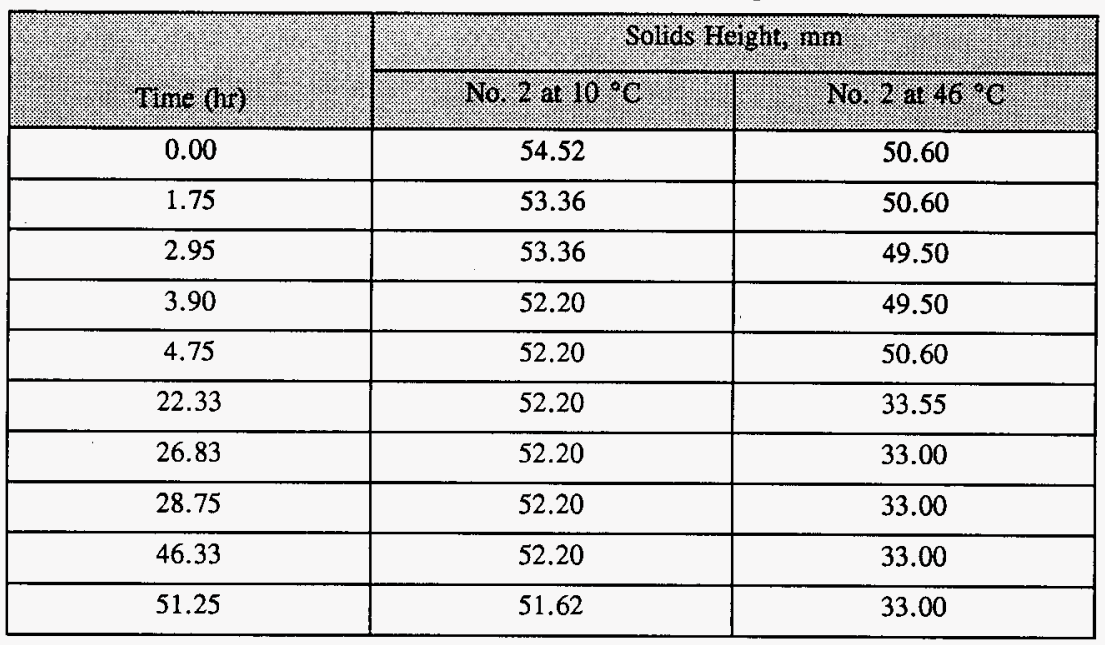

Table C-4. Solids Settling Behavior for Sample No. 2-1:1

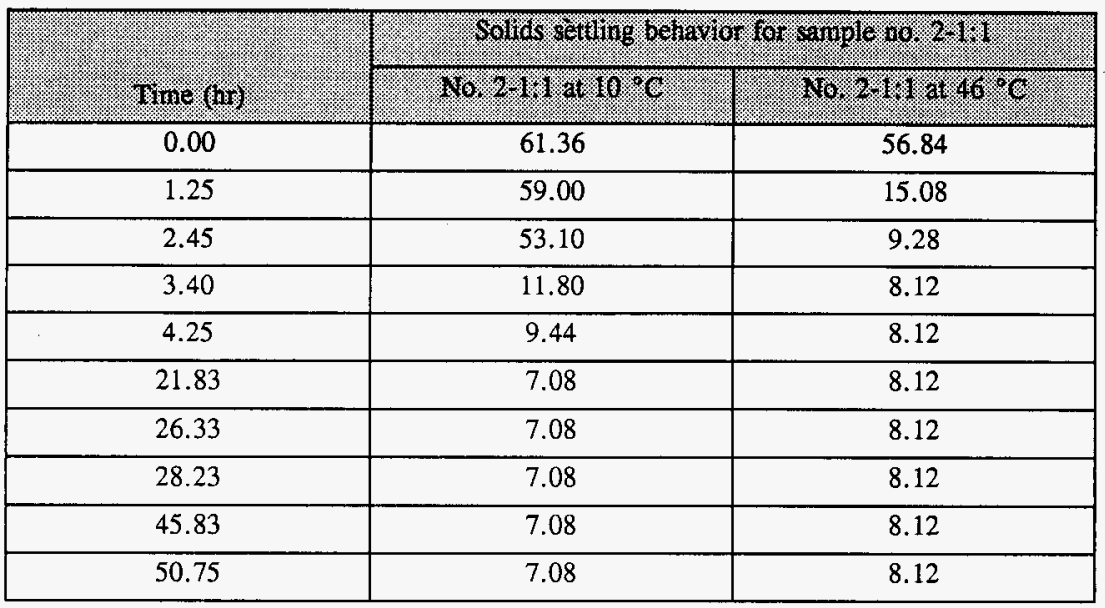


Table C-5. Solids Settling Behavior for Sample No. 12-1:1.

\begin{tabular}{|c|c|c|}
\hline \multirow{2}{*}{ (1. } & \multicolumn{2}{|c|}{ Solids Geigh, nm } \\
\hline & 19. 12,1.1 at 10\%" & Mo. $12.1 \%$ at 46.9 \\
\hline 0.00 & 59.28 & 57.12 \\
\hline 1.08 & 57.00 & 50.40 \\
\hline 2.28 & 54.72 & 36.96 \\
\hline 3.23 & 57.00 & 30.24 \\
\hline 4.08 & 59.28 & 28.00 \\
\hline 21.67 & 22.80 & 20.16 \\
\hline 26.17 & 21.66 & 19.60 \\
\hline 28.08 & 21.66 & 20.16 \\
\hline 45.67 & 19.38 & 19.60 \\
\hline 50.58 & 19.38 & 19.60 \\
\hline
\end{tabular}

Table C-6. Solids Settling Behavior for Sample No. 12-1:2.

\begin{tabular}{|c|c|c|}
\hline \multirow[b]{2}{*}{ Mrne (11) } & \multicolumn{2}{|c|}{ Solide heighi non } \\
\hline & 110.12 .12 at 10.9 & 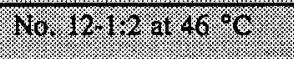 \\
\hline 0.00 & 63.44 & 61.36 \\
\hline 1.00 & 57.34 & 55.46 \\
\hline 2.20 & 42.70 & 41.30 \\
\hline 3.15 & 34.16 & 33.04 \\
\hline 4.00 & 31.11 & 30.09 \\
\hline 21.58 & 20.74 & 20.06 \\
\hline 26.08 & 20.74 & 20.06 \\
\hline 28.00 & 19.52 & 18.88 \\
\hline 45.58 & 18.91 & 18.29 \\
\hline 50.50 & 18.91 & 18.29 \\
\hline
\end{tabular}


Table C-7. Rehologial Parameters for Diluted and Undiluted Samples of Waste from Double-Shell Tank 241-SY-103 at $10^{\circ} \mathrm{C}$ and $46^{\circ} \mathrm{C}$.

\begin{tabular}{|c|c|c|c|c|c|c|c|}
\hline Irarameter & 19.2 & No. ? & No. 12 & No. $1.1 \%$ & no. & No. $12.1 \%$ & 10.12 .122 \\
\hline \multicolumn{8}{|l|}{$46^{\circ} \mathrm{C}$} \\
\hline$\tau_{y}(\mathrm{~Pa})$ & 0 & 0 & 17.7 & 0 & 0 & 0 & 0 \\
\hline $\mathrm{K}(\mathrm{Pa}-\mathrm{sec})$ & 0.0400 & 0.0856 & 0.9462 & 0.0010 & 0.0051 & 0.0070 & 0.0033 \\
\hline $\mathrm{n}$ & 0.92 & 0.95 & 0.95 & 1.18 & 0.97 & 0.99 & 1.03 \\
\hline $\mathbf{R}^{2}$ & 0.999 & 0.999 & 0.996 & 0.991 & 0.998 & 0.995 & 0.995 \\
\hline \multicolumn{8}{|l|}{$10^{\circ} \mathrm{C}$} \\
\hline$\tau_{y}(\mathrm{~Pa})$ & 0 & 0 & NA & 0 & 0 & 0 & 0 \\
\hline $\mathrm{K}(\mathrm{Pa}-\mathrm{sec})$ & 0.2747 & 0.596 & NA & 0.0053 & 0.0101 & 0.0092 & 0.0041 \\
\hline $\mathrm{n}$ & 0.96 & 0.91 & NA & 1.022 & 0.98 & 1.06 & 1.1 \\
\hline $\mathbf{R}^{2}$ & 0.999 & 0.999 & NA & 0.998 & 0.999 & 0.997 & 0.998 \\
\hline
\end{tabular}

Note:

$$
\text { NA = Unable to obtain Data }
$$


WHC-SD-WM-ER-471 Rev. 1

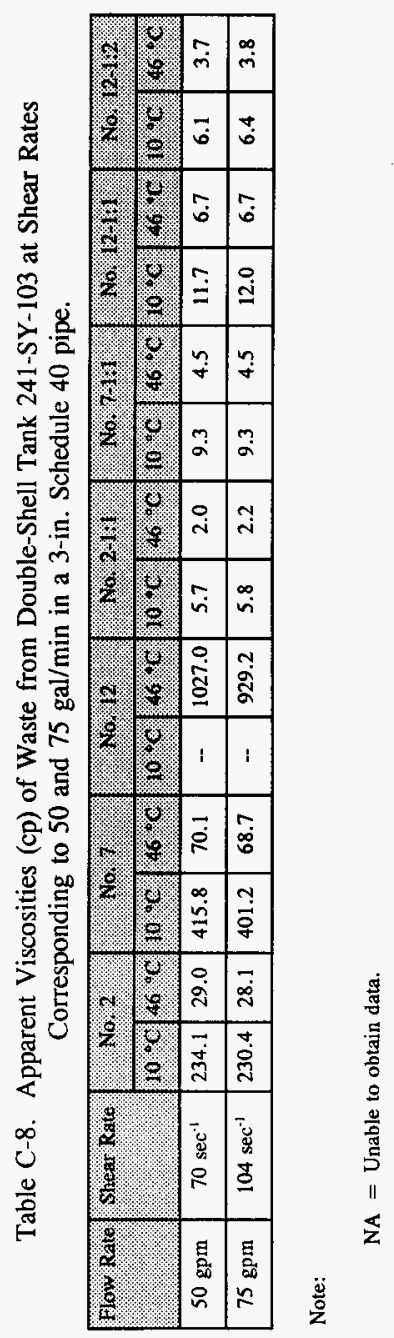


WHC-SD-WM-ER-471 Rev. 1

APPENDIX D

1994 BLIND SAMPLE RESULTS

D-1 
WHC-SD-WM-ER-471 Rev. 1

This page intentionally left blank. 


\section{APPENDIX D}

\section{BLIND SAMPLE RESULTS}

\section{Blind Sample Results}

The tank characterization plan requested blind results for three analyses; total inorganic carbon/total organic carbon, IC, and inductively coupled plasma. Presented below are the results from the water pollution performance evaluation study.

Table D-1. Inductively-Coupled Plasma Blind Results $(\mu \mathrm{g} / \mathrm{L})$.

\begin{tabular}{|c|c|c|c|c|}
\hline & Repored & True & Evaruation & Stidy ID \\
\hline $\mathrm{Al}$ & 568 & 610 & Acceptable & WP033 \\
\hline $\mathrm{Ca}$ & 87.8 & 89.0 & Acceptable & WP033 \\
\hline $\mathrm{Cr}$ & 527 & 529 & Acceptable & WP033 \\
\hline $\mathrm{Fe}$ & 1290 & 1300 & Acceptable & WP033 \\
\hline $\mathrm{K}$ & 13.7 & 14.0 & Acceptable & WP033 \\
\hline $\mathrm{Na}$ & 95.2 & 94.2 & Acceptable & WP033 \\
\hline $\mathrm{Ni}$ & 1070 & 1080 & Acceptable & WP033 \\
\hline $\mathrm{Zn}$ & 722 & 726 & Acceptable & WP033 \\
\hline
\end{tabular}

Table D-2. IC Blind Results (mg/L).

\begin{tabular}{|c|c|c|c|c|}
\hline & Reported & True & Evatuation & Sudy ID \\
\hline Chloride & 168 & 170 & Acceptable & WP033 \\
\hline Fluoride & 4.03 & 4.00 & Acceptable & WP033 \\
\hline Sulphate & 108 & 110 & Acceptable & WP033 \\
\hline Nitrate & .880 & .860 & Acceptable & WP033 \\
\hline
\end{tabular}


WHC-SD-WM-ER-471 Rev. 1

Table D-3. Total Organic Carbon Blind Results (mg/L).

\begin{tabular}{|c|c|c|c|c|}
\hline 1) & 2icported & 17. 19 & Extanination & SfIId s 18 \\
\hline TOC & 17.9 & 35 & Not Accept & WP033 \\
\hline TOC & 44.0 & 44.0 & Acceptable & WP032 \\
\hline TOC & 79.0 & 82.0 & Acceptable & WP031 \\
\hline TOC & 8.25 & 14.0 & Not Accept & WP030 \\
\hline
\end{tabular}




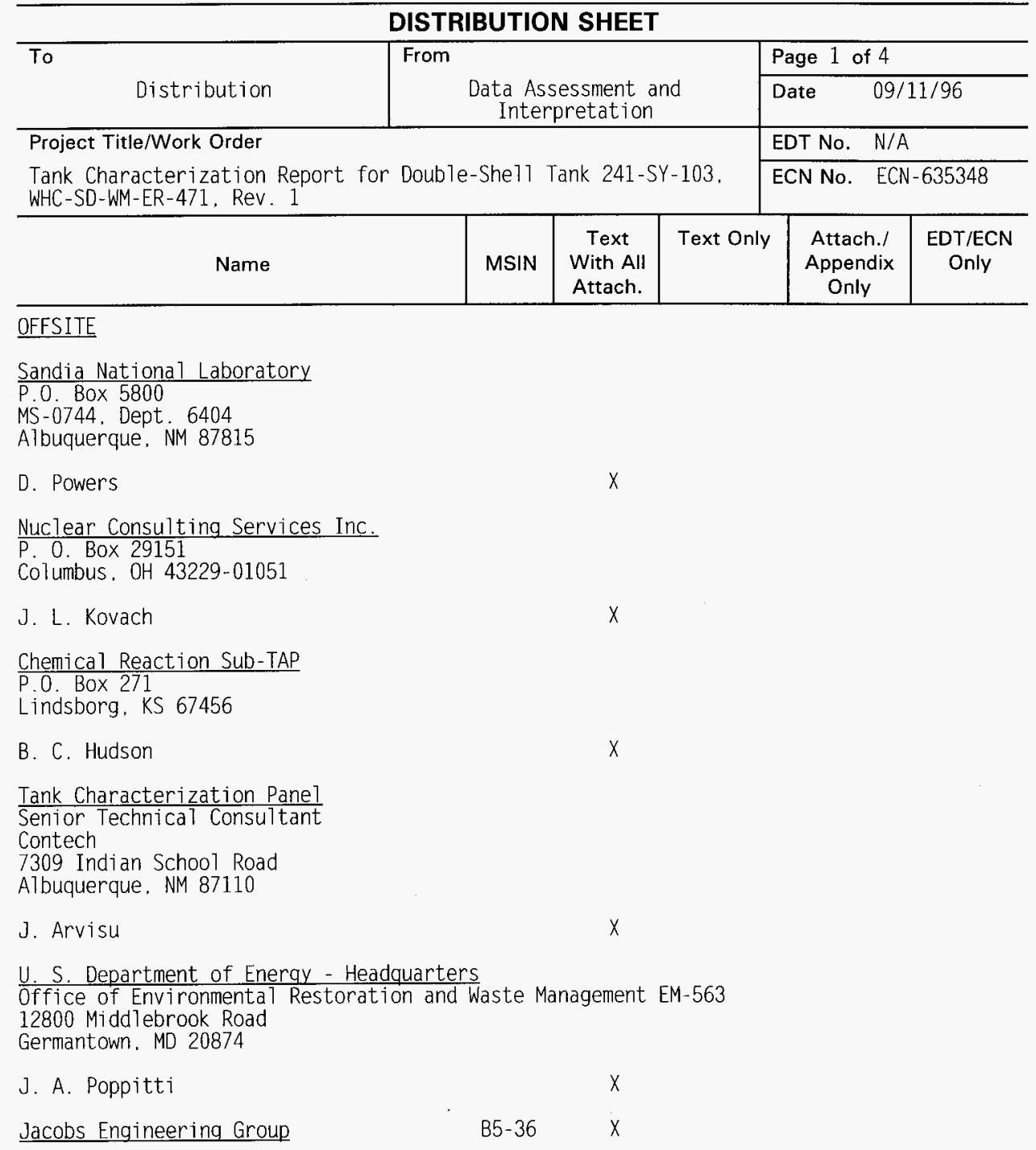




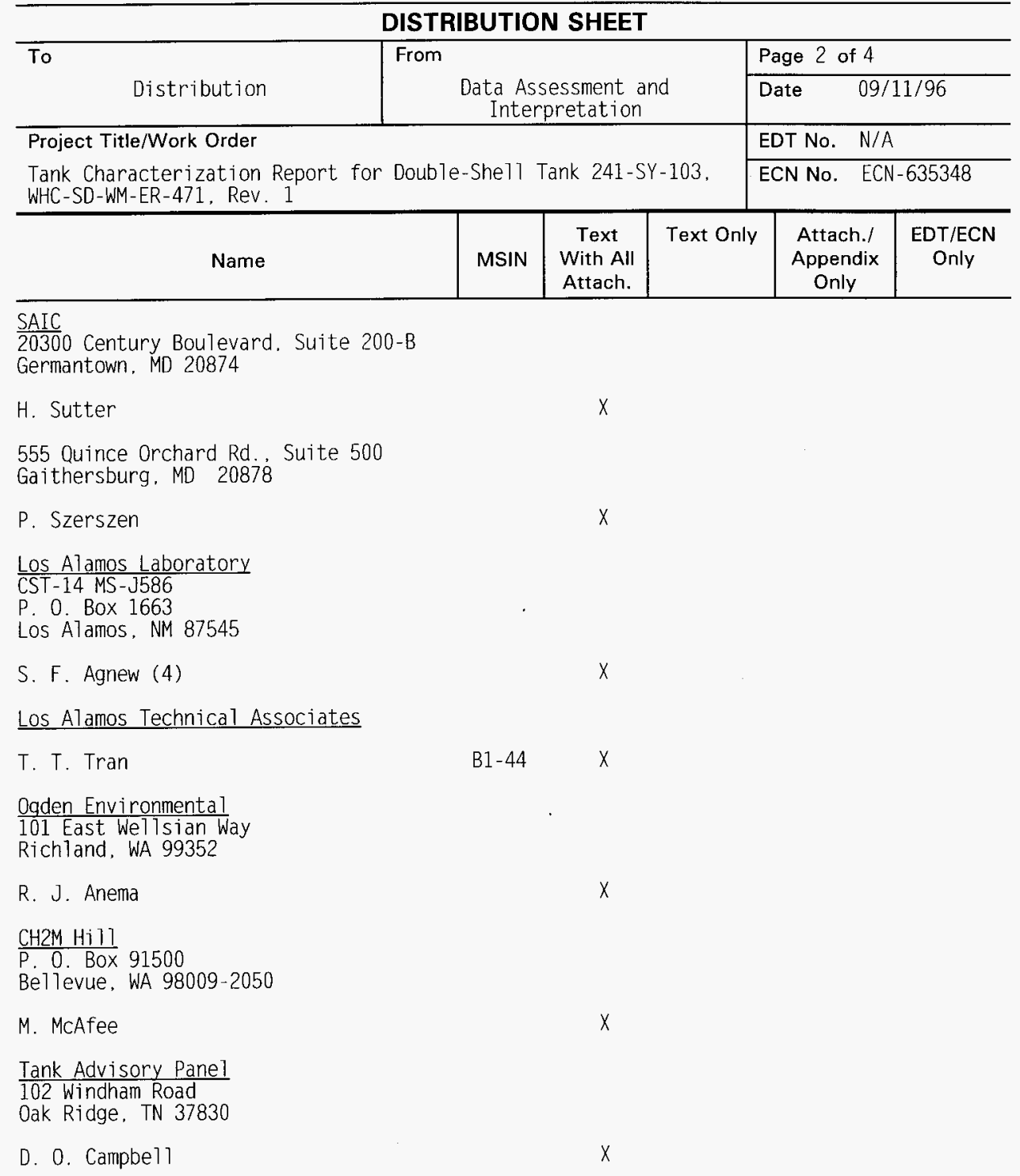




\section{DISTRIBUTION SHEET}

\begin{tabular}{|c|c|c|c|c|c|}
\hline \multirow{2}{*}{$\begin{array}{l}\text { To } \\
\qquad \text { Distribution }\end{array}$} & \multirow{2}{*}{\multicolumn{3}{|c|}{ From }} & \multicolumn{2}{|l|}{ Page 3 of 4} \\
\hline & & & & \multicolumn{2}{|c|}{$09 / 11 / 96$} \\
\hline \multicolumn{4}{|c|}{ Project Title/Work Order } & \multicolumn{2}{|l|}{ EDT No. N/A } \\
\hline \multicolumn{4}{|c|}{$\begin{array}{l}\text { Tank Characterization Report for Double-She11 Tank 241-SY-103, } \\
\text { WHC-SD-WM-ER-471. Rev. } 1\end{array}$} & \multicolumn{2}{|c|}{ ECN No. ECN-635348 } \\
\hline Name & MSIN & $\begin{array}{c}\text { Text } \\
\text { With All } \\
\text { Attach. }\end{array}$ & Text Only & $\begin{array}{l}\text { Attach./ } \\
\text { Appendix } \\
\text { Only }\end{array}$ & $\begin{array}{l}\text { EDT/ECN } \\
\text { Only }\end{array}$ \\
\hline
\end{tabular}

ONSITE

Boeing Computer Services of Richland

B. G. Lauzon

R1 - 08

$x$

Department of Eneray - Richland Operations
J. F. Thompson
S7 -54
S7 -54
S7-54 $x$
$x$
W. S. Liou
N. W. Willis

ICF-Kaiser Hanford Company

R. L. Newe 11

S3-09 $x$

Pacific Northwest Laboratory
N. G. Colton
J. R. Gormsen
J. G. Hill
G. J. Lumetta
A. F. Noonan

K3. 75

$K 7-28$

$\mathrm{K} 5-12$

K7 -94

P7 -25

K9-81

$$
\begin{aligned}
& x \\
& x \\
& x \\
& x \\
& x \\
& x
\end{aligned}
$$

Westinghouse Hanford Company

H. Babad

D. A. Barnes

G. R. Bloom

J. M. Conner

W. L. Cowley

L. A. Diaz

G. L. Dunford

E. J. Eberlein

D. B. Engelman

J. S. Garfield

S7 -14

R1-80

H5-61

R2-12

A3-37

T6-06

A2-34

R2 -12

L6-37

$\mathrm{H} 5-49$

R1-51

. G. Gubersk

T6- 09

D. Hetzer

G. Jansen

$56-31$

$46-33$

S7 -15

S7-21

T. J. Kelley

R2-11

$X$

$X$

$x$

$x$

$x$

N. W. Kirch 


\begin{tabular}{|c|c|c|c|c|c|}
\hline \multirow[b]{2}{*}{ Distribution } & \multirow{2}{*}{\multicolumn{3}{|c|}{ pretation }} & \multicolumn{2}{|l|}{ Page 4 of 4} \\
\hline & & & & \multicolumn{2}{|c|}{ Date $\quad 09 / 11 / 96$} \\
\hline \multicolumn{4}{|l|}{ Project Title/Work Order } & \multicolumn{2}{|l|}{ EDT No. N/A } \\
\hline \multicolumn{4}{|c|}{$\begin{array}{l}\text { Tank Characterization Report for Double-Shel] Tank 241-SY-103. } \\
\text { WHC-SD-WM-ER-471. Rev. } 1\end{array}$} & \multicolumn{2}{|c|}{ ECN No. $\quad$ ECN-635348 } \\
\hline Name & MSIN & $\begin{array}{c}\text { Text } \\
\text { With All } \\
\text { Attach. }\end{array}$ & Text Only & $\begin{array}{l}\text { Attach./ } \\
\text { Appendix } \\
\text { Only }\end{array}$ & $\begin{array}{c}\text { EDT/ECN } \\
\text { Only }\end{array}$ \\
\hline
\end{tabular}

Westinghouse Hanford Company continued

M. J. Kupfer

J. E. Meacham

W. C. Miller

C. T. Narquis

D. E. Place

D. A. Reynolds

L. M. Sasaki

L. W. Shelton, Jr.

B. C. Simpson

G. L. Troyer

L. R. Webb

W. I. Winters

K. A. White

Central Files

EDMC

ERC (Environmental Resource Center)

TCRC (10)

$\begin{array}{ll}\text { H5 }-49 & X \\ \text { S7 }-15 & X \\ \text { R1 }-56 & X \\ \text { T6-16 } & X \\ \text { H5-27 } & X \\ \text { R2 }-11 & X \\ \text { R2 }-12 & X \\ \text { H5-49 } & X \\ \text { R2 }-12 & X \\ \text { T6-50 } & X \\ \text { T6-06 } & X \\ \text { T6-50 } & X \\ \text { S5 }-13 & X \\ \text { A3 }-88 & X \\ \text { H6-08 } & X \\ \text { R1 }-51 & X \\ \text { R2 }-12 & X\end{array}$

